\title{
Het komt zelden voor : beheersing van klachten en geschillen in relaties tussen bedrijven
}

Citation for published version (APA):

Jettinghoff, A. (2001). Het komt zelden voor : beheersing van klachten en geschillen in relaties tussen bedrijven. [Doctoral Thesis, Maastricht University]. Datawyse / Universitaire Pers Maastricht. https://doi.org/10.26481/dis.20010926aj

Document status and date:

Published: 01/01/2001

DOI:

10.26481/dis.20010926aj

Document Version:

Publisher's PDF, also known as Version of record

\section{Please check the document version of this publication:}

- A submitted manuscript is the version of the article upon submission and before peer-review. There can be important differences between the submitted version and the official published version of record.

People interested in the research are advised to contact the author for the final version of the publication, or visit the DOI to the publisher's website.

- The final author version and the galley proof are versions of the publication after peer review.

- The final published version features the final layout of the paper including the volume, issue and page numbers.

Link to publication

\footnotetext{
General rights rights.

- You may freely distribute the URL identifying the publication in the public portal. please follow below link for the End User Agreement:

www.umlib.nl/taverne-license

Take down policy

If you believe that this document breaches copyright please contact us at:

repository@maastrichtuniversity.nl

providing details and we will investigate your claim.
}

Copyright and moral rights for the publications made accessible in the public portal are retained by the authors and/or other copyright owners and it is a condition of accessing publications that users recognise and abide by the legal requirements associated with these

- Users may download and print one copy of any publication from the public portal for the purpose of private study or research.

- You may not further distribute the material or use it for any profit-making activity or commercial gain

If the publication is distributed under the terms of Article $25 \mathrm{fa}$ of the Dutch Copyright Act, indicated by the "Taverne" license above, 
HET KOMT ZELDEN VOOR 
ISBN 90-805879-2-3

Uitgegeven door Metajuridica Publications

in samenwerking met Universitaire Pers Maastricht

C Alex Jetringhoff, Nijmegen 2001

Het boek kan worden besteld per c-mail: Argentine.Lankkampemetajur.unimaas.nl of per fax: 043-3884912.

Verzending geschiedt na ontvangst van fl. 65,- op Postbankrekening 1022880 of SNS-Bankrekening 857982990, tnv Universiteit Mastricht, onder vermelding van "Het komt zelden voor", budgetnummer $32450001 \mathrm{~N}$. 


\section{HET KOMT ZELDEN VOOR}

\section{Beheersing van klachten en geschillen in relaties tussen bedrijven}

\section{PROEFSCHRIFT}

ter verkrijging van graad van doctor aan de Universiteit Maastricht op gezag van de Rector Magnificus

Prof. dr. A.C. Nieuwenhuijzen Kruseman volgens het besluit van het College van Decanen, op woensdag 26 september 2001 om 16.00 uur

$$
\text { door }
$$

Alexander Jettinghoff 
Promotores:

Prof. mr. N.H.M. Roos

Prof. dr. E.R. Blankenburg (Vrije Universiteit)

Beoordelingscommissie:

Prof. dr. G.A.A. J. van den Heuvel (voorzitter)

Prof. dr. H.F.M. Crombag

Prof. mr. C.A. Groenendijk (Katholieke Universiteit Nijmegen)

Prof. mr. N.J.H. Huls (Erasmus Universiteit Rotterdam)

Dr. R.J.S. Schwitters (Rijksuniversiteit Groningen) 
"When crossing the mountains, be sure to stay close to the valleys; when encamping, select high ground facing the sunny side; when bigh ground is occupied by the enemy, do not ascend to attack. So much for taking a position in the mountains."

Sun Tzu, The Art of War. [Hst. 9] 



\section{Woord vooraf}

In dit boek zijn twee van mijn interesses samengekomen. De eerste, oudste interesse heeft betrekking op de 'cliënten' van het rechtsbedrijf, meer in het bijzonder de rechtspraak. Het gaat om vragen als: wie zijn ze, wat gaat er vooraf aan het doen van gerechtelijke stappen, wat beweegt ze ertoe dergelijke stappen te doen of wat houdt ze er juist vanaf, wat is hun oordeel over behandeling en uitkomst. Ook het onderzoek waarvan hier verslag wordt gedaan, sluit bij dit traditionele thema uit de rechtssociologie aan. De tweede, meer recente interesse betreft de betekenis van het proces van staatsvorming voor rechtsontwikkeling. Het is nog niet zozeer een voorwerp van empirisch onderzoek geworden, maar fungeert meer als een nieuw interpretatiekader. Het stelt me in staat gebruikelijke rechtssociologische thema's door een andere bril te bezien. Ik heb de gelegenheid aangegrepen dit nieuwe interpretatiekader ook los te laten op mijn oude thema, omdat ik al enige tijd geen vrede kon hebben met de meest gehanteerde kaders.

In de verschillende interesses ben ik door verschillende mensen gestimuleerd. Hans Crombag heeft me aangespoord over de probleempreventie van postorderbedrijven te schrijven. Dit onderzoek heeft daarop in feite voortgebouwd. Bij de uitvoering van dit onderzoek en de verslaglegging er over, heb ik zeer veel steun en waardevolle raad gehad van Erhard Blankenburg. Ik heb zijn aanmoedigingen en gastvrije ontvangst in Amsterdam zeer gewaardeerd. Ook de steun van Nico Roos, niet alleen wat betreft inhoud maar ook wat betreft de facilitering van mijn onderzoekswerk, is van wezenlijk belang geweest. Voorts ben ik de leden van de leescommissie dankbaar voor hun commentaar en suggesties.

Mijn eerste exercities op het veld van recht en staatsvorming heb ik ondernomen met Huub Spoormans. Ik denk met plezier terug aan ons geworstel met de materie. Frank van Dun heeft mijn oefeningen op dit thema verder geïnspireerd, vooral tijdens de seminars aan de "Vrije Universiteit Bilzen" en in het kader van het blok Metajuridica.

Verschillende mensen hebben me aan zich verplicht door behulpzaam te zijn bij de uitvoering van dit project. Allereerst dienen natuurlijk de respondenten genoemd te worden, die bereid zijn geweest me een blik in hun keuken te gunnen. Rob Francot heeft veel noeste arbeid verzet voor de bewerking van de op tape opgenomen interviews. Elly Peters en Argie Lankkamp hebben opgewerkt de nodige secretariële steun verleend. Olga Loeber, Noortje en Gerrit Bax, dochter Jitske en 
vader Jan Jettinghoff hebben geholpen de tekst te corrigeren. Rob Bakker en Marc Stout hebben hun best gedaan het Engels van de samenvatting te fatsoeneren. Zonder de steun van Olga zou ik waarschijnlijk niet aan deze onderneming zijn begonnen.

Maastricht, juli 2001 


\section{INHOUDSOPGAVE}

\section{HOOFDSTUK 1}

\section{Inleiding}

1. Reflexieve praktijken

2. Duurzame relaties 17

3. Juridische infrastructuur 18

4. Benadering en onderzoeksopzet 19

5. Opzet van deze studie 20

HOOFDSTUK 2

Statelijke rechtspraak:

alleen antwoord op maatschappelijke behoeften? 21

1 Verschillende motieven 22

1.1 Technocratisch denken 22

1.2 Sociale hervorming 25

1.3 Algemene theorie 27

2 Kerend tij 29

3 Staatsvorming als invalshoek 31

4 Staatsvorming en rechtspraak $\quad 40$

5 Rechtspraak en 'alternatieven' 45

6 Besluit 48

HOOFDSTUK 3

Vraagstelling en onderzoeksopzet 51

1 Beheersing van klachten en geschillen 52

2 Relaties tussen bedrijven $\quad 55$

3 De juridische infrastructuur $\quad 58$

3.1 Cultuur 59 
3.2 Aanbod 60

4 Een contextuele benadering: de logica van het ondernemen 66

5 Over storingen, klachten, geschillen en juridische stappen 68

6 De interview-agenda $\quad 70$

$\begin{array}{lll}7 & \text { Keuze van bedrijfstakken } & 71\end{array}$

8 De internationale vergelijking 73

8.1 Vergeleken gebieden 73

$\begin{array}{ll}8.2 \text { Branches } & 78\end{array}$

9 Materiaalverzameling en-verwerking 78

HOOFDSTUK 4

De logica van het ondernemen $\quad 81$

1 Kunststofverwerking: dominante partners 81

1.1 Leveranciers $\quad 82$

1.2 Klanten 90

1.3 Concurrenten 98

$\begin{array}{llr}1.4 & \text { Summer } & 99\end{array}$

$\begin{array}{ll}1.5 & \text { Resumerend }\end{array}$

2 Wegtransport 100

$\begin{array}{lll}2.1 & \text { Leveranciers } & 101\end{array}$

$\begin{array}{ll}2.2 & \text { Opdrachtgevers } \\ 2.3 & 102\end{array}$

$\begin{array}{ll}2.3 \text { Concurrenten } & 105\end{array}$

2.4 Resumerend 106

3 Hoofdaannemers in de bouwnijverheid 106

$\begin{array}{lll}3.1 & \text { Leveranciers } & 107\end{array}$

$\begin{array}{ll}3.2 & \text { Opdrachtgevers } \\ 3.313\end{array}$

$\begin{array}{ll}3.3 \text { Concurrenten } & 120\end{array}$

3.4 Resumerend 121

4 Eerste conclusies $\quad 121$

4.1 Reflexieve methoden 122

4.2 Duurzame relaties 124

4.3 Klachten, geschillen en juridische stappen 125

Bijlage Hoofdstuk $4 \quad 126$ 


\section{HOOFDSTUK 5}

De invloed van de juridische infrastructuur: een grensoverschrijdend perspectief

1 Kunststofverwerking in Duitsland en België: van eenzelfde laken 130

1.1. Leveranciers

1.1.1 Preventie van klachten

1.1.2 Omgaan met klachten in de relatie met leveranciers

1.2.1 Klachtenpreventie in de relatie met klanten

1.2.2 Omgaan met klachten in de relatie met klanten

1.3 Concurrenten

1.4 Geschillen en juridische stappen

2 Hoofdaannemers in de Duitse en Belgische bouwnijverheid:

Verschillende structuren en calculaties

2.1 Leveranciers van bouwmaterialen

2.1.1 Preventie van klachten

2.1.2 Omgaan met klachten in de relatie met leveranciers $\quad 160$

2.2 Onderaannemers

$\begin{array}{lll}2.3 & \text { Opdrachtgevers } & 166\end{array}$

2.4 Concurrenten 172

2.5 Geschillen en juridische stappen 173

3 Resumerend 178

Bijlage Hoofdstuk $5 \quad 180$

HOOFDSTUK 6

\section{Conclusies}

1 Preventie en hantering van klachten en geschillen

1.1 Preventie

1.2 Omgaan met klachten over storingen 190

1.3 Geschillen en juridische stappen 192

2 De logica van het ondernemen 193

3 Aspecten van economische bindingen 196

3.1 Betrouwbaarheid 196

$\begin{array}{lll}3.2 & \text { Stabiliteit } & 197\end{array}$

3.3 Partnerschap (1): bescherming tegen contingenties 198

3.4 Partnerschap (2): bescherming tegen concurrenten 199 
3.5 Partnerschap (3): kwaliteit 200

3.6 Ontbinding van economische bindingen 201

4 Het gewicht van de juridische infrastructuur 202

5 Burgerlijke rechtspraak tussen vraag en aanbod 205

6 Resumerend 207

$\begin{array}{ll}\text { SUMMARY } & 209\end{array}$

$\begin{array}{ll}\text { LITERATUURLIJST } & 217\end{array}$

CURRICULUM VITAE 233 


\section{HOOFDSTUK 1}

\section{Inleiding}

Af en toe besteden de media aandacht aan een conflict tussen bedrijven dat is uitgemond in een gerechtelijke strijd. Zo werd in 1994 aan het conflict tussen Unilever en Proctor \& Gamble (over Omo-power) veel aandacht in de media besteed. Een recenter voorbeeld is het conflict in 1999 tussen Gucci en LVMH rond overnameperikelen. ${ }^{2}$ Begin 2001 trok de oprichting van de Vereniging Corporate Litigation de aandacht, die de grotere bereidheid van het bedrijfsleven om naar de rechtszaal te gaan, van deskundige begeleiding zou gaan voorzien. ${ }^{3}$ Het is echter maar de vraag of dergelijke smakelijke nieuwsberichten mogen worden opgevat als een indicatie van een grotere bereidheid van bedrijven dan voorheen bestond om tegen elkaar gerechtelijke stappen te ondernemen. Het werk van de rechtssocioloog Macaulay wijst sinds 1963 in een andere richting, al is sindsdien door latere schrijvers gesuggereerd dat het beeld uit die tijd intussen veranderd is. ${ }^{4}$

In dit onderzoek wordt gepoogd wat meer licht te werpen op de wijze waarop bedrijven omgaan met de onderlinge conflictstof, die kan voortvloeien uit zakelijke transacties en die aanleiding kunnen zijn tot het doen van juridische stappen. In het bijzonder zal de aandacht uitgaan naar methoden of praktijken die het ontstaan van conflictstof voorkomen.

De aandacht voor preventie houdt verband met de fameuze these van Galanter, dat 'repeat players' ten opzichte van 'one shotters' - wanneer het op procederen aankomt - in het voordeel zijn, omdat ze lering kunnen trekken uit hun eigen ervaringen. ${ }^{5}$ Mijn vraag daarbij is geweest of ze dat ook daadwerkelijk doen. Uit

1 Zie voor een verslag: Riezebos en Warts (1994) Power play.

2 Timmerman (1999) Kroniek van het vennootschapsrecht, p. 1499; FEM/DeWeek 17 - 4 - 99.

3 Het Financiecle Dagblad, 28-2-2001; NJB (2001) jig. 76, afl. 11, p. 569.

4 Macaulay (1963) Non-contractual relations in business; anders: Galanter en Rogers (1991) The transformation of American busines disputing.

5 Galanter (1974) Why the 'haves' come out ahead. 
eerder onderzoek bleek dat sommige bedrijven inderdaad proberen lering te trekken uit hun ervaringen met het innen van achterstallige betalingen van hun particuliere klanten. ${ }^{6} \mathrm{Ze}$ hebben soms ook ingenieuze methoden ontwikkeld om betalingsproblemen voor een deel te voorkomen en slagen er zo in de noodzaak tot het doen van juridische stappen in dergelijke kwesties te minimaliseren.

De vraag die in dit onderzoek aan de orde komt luidt of dergelijke (of andere) methoden ook in het verkeer tussen bedrijven onderling worden gebruikt. Deze methoden zijn op zich al interessant omdat ze lijken te horen bij de hedendaagse 'maatschappij van organisaties'. Daarnaast is dit verschijnsel hopelijk ook relevant in het kader van twee rechtssociologische thema's. Het eerste thema betreft de vraag of het groeiend beroep van bedrijven op de civiele rechter, dat wel is gesignaleerd, een uitvloeisel is van veranderende verhoudingen in het internationale bedrijfsleven. Het tweede thema betreft een discussie over de oorzaken van de opmerkelijke verschillen in 'litigation rates' die voor diverse landen zijn gesignaleerd. Deze drie onderwerpen zullen in het volgende kort worden toegelicht, waarna de indeling van dit boek zal worden aangegeven en toegelicht.

\section{Reflexieve praktijken}

'Reflexiviteit' is volgens de Britse socioloog Giddens een typerend kenmerk van moderne maatschappijen. Hij omschrijft het als het verschijnsel dat organisatorische praktijken, op grond van gegevens die over die praktijken zijn verzameld, voortdurend geèvvalueerd en aangepast worden, als gevolg waarvan die praktijken op den duur wezenlijk van karakter veranderen. ${ }^{7}$ Organisaties proberen van hun eigen ervaringen te leren en voor het beter bereiken van hun 'missie' trachten ze aan die lessen consequenties voor de inrichting van de organisatie te verbinden.

Om diverse redenen is dit vanuit sociologisch perspectief een interessant fenomeen. Allereerst omdat organisaties in toenemende mate het westerse maatschappelijk leven zijn gaan domineren. De organisatiesocioloog Perrow typeerde de moderne maatschappij als "a society of organizations". ${ }^{8}$ Daardoor is er een voedingsbodem ontstaan voor reflexieve processen, die in aggregatie een enorme maatschappelijke dynamiek kunnen genereren. Voorts is het een interessant verschijnsel, omdat het een veranderingsmechanisme aanduidt waarbij het handelen van actoren niet - zoals zo vaak - gepresenteerd wordt als passief gedetermineerd,

6 Jettinghoff (1991) Daderprofielen in het privaatrecht.

7 Giddens (1990) The consequences of modernity. p. 38.

8 Perrow (1991) A society of onganizations. 
maar als gegenereerd vanuit een actieve opstelling van actoren ten aanzien van de context waarin (organisatorische) activiteiten zijn ingebed: om zich aan te passen aan de gegeven of veranderde omstandigheden, om de omstandigheden in de gewenste richting te buigen of een combinatie daarvan, afhankelijk van hetgeen voor hen wenselijk en naar hun inschatting mogelijk is.

Die mogelijkheden hebben de afgelopen decennia een stormachtige ontwikkeling doorgemaakt. Vooral de expanderende mogelijkheden van de informatietechnologie hebben telkens nieuwe perspectieven geopend voor reflexieve methoden. Op het vlak van het verzamelen en bewerken van gegevensbestanden is steeds meer mogelijk en betaalbaar geworden. Onder dit gunstig gesternte van bureaucratisering en technologische vernieuwingen vinden reflexieve methoden een steeds wijdere toepassing. De verschijningsvormen van reflexiviteit zijn talrijk geworden in het moderne dagelijks leven.

Als voorbeeld van reflexiviteit heeft Giddens gewezen op het richten en bijsturen van staatsinterventies op grond van statistische en andere wetenschappelijke informatie over de betreffende beleidsterreinen. ${ }^{9}$ Maar reflexiviteit is niet alleen voorbehouden aan overheidsorganisaties. Het is volgens Giddens typerend voor alle organisaties, ook buiten de staatsbureaucratie. ${ }^{10}$ Aardige voorbeelden zijn te ontlenen aan marketinginspanningen van grote bedrijven, die naar de gunst van consumenten dingen.

Supermarktketens distribueren klantenkaarten om beter genformeerd te zijn over het koopgedrag van hun klanten, om nog beter aan hun individuele wensen tegemoet te kunnen komen. De ontwikkeling zou gaan in de richting van 'massa-individualisme'. Banken worden uitgerust met 'klantgerichte systemen' die alle beschikbare informatie over individuele klanten bijeen brengen om deze klanten op het juiste moment op hem of haar toegesneden diensten te kunnen aanbieden ('maatwerkmomenten'). ${ }^{11}$ Ook de autoproducenten blijken greep te willen krijgen op de afzetmarkt, door de automobilist beter te leren 'kennen'. ${ }^{12}$ Men spreekt van 'voorwaartse integratie'. Het gaat er niet alleen om auto's te verkopen, maar 'mobiliteit' met alles wat dat meebrengt aan onderhoud, financiering, verzekering enzovoorts. Wie de signalen van deze methoden herkent weet zich omringd door dergelijke praktijken. Klantenkaarten, rekeningen, abonnementen en postcodes zijn informatiebronnen die, vooral als ze geclusterd kunnen worden, mogelijkheden bieden voor allerlei marketingdoeleinden. Mensen zijn

9 Giddens, t.a.p, p. 38.

10 Ibid., p. 40 e.v.

11 Jettinghoff (1997) Voorkomen van wanbetalen, p. 63.

12 Ontleend aan FEM/DeWeek 17- 7 - 99. 
hier, zoals het wel genoemd is, tot 'data subjecten' geworden. ${ }^{13}$ En dat is dan te merken aan de marketinginitiatieven waarmee men via alle beschikbare communicatiekanalen benaderd wordt. De recente activiteiten van de 'gratis' internet providers wijzen erop dat deze ontwikkeling via het internet, met de zich nu ontplooiende 'e-commerce', nog meer wind in de zeilen zal krijgen.

In verband met het onderhavige onderzoek is vooral interessant, dat dergelijke reflexieve methoden in sommige bedrijfstakken ook gebruikt blijken te worden om het aantal (vooral betalings-)problemen met particuliere klanten, die op een gerechtelijke procedure kunnen uitlopen, binnen 'aanvaardbare' perken te houden. ${ }^{14}$ Verschillende methoden zijn blijkbaar in zwang:

- de behandeling van transacties en de afdoening van de eventuele problemen wordt op basis van de opgedane informatie zodanig vorm gegeven, dat de routinematige administratieve beslissingen daarin - ook die over het doen van juridische stappen - zo efficiënt mogelijk zijn;

- klanten die op grond van een analyse van de eigen administratieve databestanden een 'slecht' risicoprofiel hebben, worden met voorzorg behandeld of komen op de zwarte lijst.

- er wordt werk gemaakt van het aantrekken van 'goede' klanten, dat wil zeggen: klanten met een 'goed' risicoprofiel. Dergelijke profielen kunnen worden gemaakt op basis van externe databestanden die vervolgens worden aangevuld met gegevens uit de eigen databestanden.

Al deze methoden veronderstellen de betaalbare capaciteit om aanzienlijke databestanden aan te leggen en te analyseren. Dan is het mogelijk om van de eigen ervaringen te leren en om potentiële rechtsproblemen voor een belangrijk deel te voorkomen. Het zou met behulp van deze reflexieve methoden in beginsel zelfs mogelijk zijn dergelijke problemen vrijwel geheel te voorkomen. ${ }^{15}$

Dit onderzoek is in de eerste plaats gericht op de vraag hoe mogelijke conflictstof die in de relaties tussen bedrijven ontstaat, wordt afgehandeld en welke rol het doen van juridische stappen daarbij speelt. Daarbij is het in het bijzonder de vraag of, en zo ja, hoe en op grond van welke overwegingen, reflexieve technieken (gericht op het voorkomen van conflictstof) in relaties tussen bedrijven onderling worden toegepast, en of ze het beoogde effect hebben.

13 Newsweck, (1999) eindejaarsnummer, p. 90.

14 Zie verder: Jettinghoff (1991) Daderprofielen.

15 Dat kan evenwel weer stuiten op commerciele bezwaren; om niet te veel klandizie te verliezen uit voorzichtigheid, neemt men enig risico op problemen op de koop toe. 


\section{Duurzame relaties}

Een mogelijk uitvloeisel van het op schaal van enige omvang in zwang komen van dergelijke preventieve praktijken kan zijn, dat het beroep op de (burgerlijke) rechter - in ieder geval voor de betrokken categorie geschillen - kan afnemen of althans niet toeneemt. ${ }^{16}$ Die constatering brengt ons op het terrein van een bekende rechtssociologische thematiek.

Aan het eind van de ' 80 -er jaren meenden Galanter en Rogers dat het beeld dat Macaulay had geschetst over de contractuele praktijken in het zakenleven van de jaren ' 50 en ' 60 al sinds het begin van de jaren '70 niet meer adequaat was. Volgens Macaulay werd bij zakentransacties weinig gerefereerd aan het contractenrecht en het afhandelen van klachten en geschillen gebeurde veelal zonder een beroep op contractuele rechten en plichten of het gebruik van juridische dwangmiddelen (zoals procederen). Galanter en Rogers hebben een aantal ontwikkelingen gesignaleerd, die zij verantwoordelijk achtten voor deze verandering. Tot die ontwikkelingen rekenden zij onder andere de grociende concurrentie tussen bedrijven, de toegenomen ruimtelijke en culturele afstand tussen firma's - beide ontwikkelingen gerelateerd aan de internationalisering van het economisch verkeer. Ook de toename van de omvang en complexiteit van transacties waren mogelijk van invloed. Deze ontwikkelingen zouden de door Macaulay geschetste structuren van 'duurzame betrekkingen' hebben ondergraven. En dientengevolge zouden het maken van afspraken en het hanteren van geschillen meer aan contractuele planning onderworpen worden. Bovendien zouden ze - in ieder geval aanvankelijk - resulteren in meer procedures tussen bedrijven.

Later statistisch onderzoek van Dunworth en Rogers heeft deze veronderstellingen niet bevestigd. ${ }^{18}$ Volgens hun gegevens was de groei van het aantal procedures tussen bedrijven in de 70-er en 80 -er jaren vooral het effect van een selecte groep productaansprakelijkheidskwesties. Wanneer deze categorieën rechtszaken voor het verkrijgen van een algemeen beeld niet worden meegeteld, dan constateren zij dat het aantal civiele procedures in het zakenleven minder gegrocid is dan alleen al op grond van de economische groei verwacht zou mogen worden. Voor verschillende categorieën geschillen zien zij zelfs meer reden om de ontwikkeling te karakteriseren als een afname van het procederen tussen bedrijven.

16 Voor een voorbeeld: zie Jettinghoff en Langerwerf (1982) Over rechters en rechtbanken, p. 30.

17 Galanter \& Rogers (1991) The transformation; ook: Galanter, Macaulay, Palay, Rogers (1991) The transformation.

18 Dunworth \& Rogers (1996) Corporations in court. 
Het gaat in dit onderzoek in de eerste plaats om de aard, het gebruik en het eventuele preventieve effect van de hierboven genoemde praktijken. Het is denkbaar dat deze methoden het door Galanter en Rogers voorspelde effect hebben ondervangen. Maar daarnaast is het ook de bedoeling een indruk te verkrijgen van het (voort)bestaan van de (door Macaulay geschetste) 'duurzame relaties' in het bedrijfsleven, en de omstandigheden die dit begunstigen. Mogelijk zijn deze duurzame relaties nog springlevend en versterken de reflexieve methoden en de duurzame relaties elkaar. ${ }^{19}$

\section{Juridische infrastructuur}

Het andere thema waarvoor dit onderzoek van betekenis kan zijn betreft de verklaring van de verschillen in de relatieve frequentie van het beroep op de burgerlijke rechter, die uit internationaal vergelijkend onderzoek naar voren zijn gekomen.

Sommige schrijvers hebben deze verschillen in verband gebracht met cultuurverschillen. De klassieke positie is die van Kawashima, die heeft uiteengezet hoe de heersende conceptie van veel sociale relaties (zoals die tussen huurder en verhuurder, koper en verkoper, werknemer en werkgever) in Japan het ontstaan en escaleren van conflicten in die relaties en het doen van gerechtelijke stappen verhindert. ${ }^{20}$ Mocht een geschil ontstaan dan ligt een minnelijke schikking, desnoods via tussenkomst van een bemiddelaar, meer voor de hand dan de gang naar de rechter.

Een min of meer tegenovergestelde positie is ingenomen door Haley (voor Japan) en Blankenburg en Verwoerd (voor Nederland en Duitsland). ${ }^{21}$ Deze auteurs hebben vooral de invloed benadrukt van institutionele factoren (zoals het aanbod van rechtshulp en alternatieve geschilbehandeling en voorts de kosten - in termen van tijd en geld - en mogelijke baten van formeel procederen) in het afleiden van geschillen van (respectievelijk het leiden van geschillen naar) de rechter. De meest uitgesproken positie aan deze zijde van het debat wordt ingenomen

19 De mogelijkheid van een verband ziet men gellustreerd in de consumentensector, bij bedrijven die reflexieve methodieken hanteren om 'goede' klanten te selecteren en aan zich te binden, mede met het oog op het beperken van betalingsproblemen. Cf. Jetringhoff (1991) Daderprofielen.

20 Kawashima (1964) Dispute resolution in contemponary Japun.

21 Haley (1978) The myth of the reluctant litigant; Blankenburg (1985) Indikatorenvergleich der Recheskelturen in der Bundesrepublik und den Niederlanden: Verwoerd (1988) Het bervep op de rechter ab laatste nemedie? 
door Blankenburg. ${ }^{22}$ Naar zijn opvatting is het vrijwel uitsluitend de configuratie van de genoemde instellingen, die hij de 'infrastucture of avoidance' noemt, die bepaalt of er veel of weinig wordt geprocedeerd.

Het is deze laatste positie die tevens in dit onderzoek zal worden betrokken. Met name zal de vraag zijn of een 'royale' respectievelijk 'zuinige' juridisch-institutionele context van betekenis is voor het streven (al dan niet met de inzet van speciale technieken) naar preventic van conflictstof, die uit de zakelijke transacties met andere bedrijven kan voortkomen en voor de wijze waarop desondanks ontstane klachten en geschillen (al dan niet via gerechtelijke weg) worden afgewikkeld. Met het oog hierop is aan het onderzoek een internationaal vergelijkend element toegevoegd.

\section{Benadering en onderzoeksopzet.}

De in de twee voorgaande paragrafen weergegeven discussies zijn vooral gevoerd op basis van de analyse van statistische gegevens. Naar aanleiding van de bevindingen die worden gedaan kan op basis van dergelijke gegevens slechts worden gespeculeerd over de processen die aan die processen ten grondslag zouden kunnen liggen; tenzij er nader onderzoek wordt gedaan naar die achtergronden. Daarbij kunnen verschillende benaderingen worden gekozen. Een veel gebruikte aanpak daarbij komt neer op het in (statistisch) verband brengen van gedrag van mensen met bepaalde factoren. Die methode is hier niet gekozen.

Hier daarentegen is een benadering gevolgd die beoogt een kwalitatief beeld te verkrijgen van de wijze waarop het handelen van actoren (met betrekking tot het voorkomen en afhandelen van mogelijke conflictstof) als 'rationeel' begrepen kan worden, gezien hetgeen ze willen bereiken en gezien de omstandigheden (de eigenschappen van hun branche en hun zakelijke relaties, in het bijzonder leveranciers en klanten) waarin ze hun activiteiten ontplooien. Het gaat om het achterhalen van elementen van de positie van de bedrijfsleiding die diens handelwijzen ten aanzien van het voorkomen en afhandelen van potentiële geschillen 'logisch' maken.

Daartoe zijn interviews afgenomen met bedrijfsleiders (of hun woordvoerders) van ondernemingen uit het midden- en kleinbedrijf uit verschillende bedrijfstakken in Nederland. Op basis van dit materiaal wordt getracht de eerste cluster vragen te beantwoorden. De overige vragen kunnen alleen bij benadering worden beantwoord als er een internationale vergelijking wordt gedaan. Daartoe 
zijn de bedrijfstakken, die in Nederland het meest duidelijk blijken te contrasteren wat betreft de aanwezigheid van conflictstof - de kunststofindustrie en de bouwnijverheid - ook onderzocht in Duitsland en België.

\section{Opzet van deze studie}

Het eerst volgende hoofdstuk (2) bevat een beschouwing over de verschillende optieken van waaruit in de rechtssociologische literatuur het thema 'beroep op de rechter' meestal is benaderd. Het hoofdstuk is voortgekomen uit onvrede met deze - soms als vanzelfsprekend gehanteerde - benaderingen en beoogt enige afstand te nemen van de implicaties die deze benaderingen voor het onderzoek zouden kunnen hebben. In de plaats daarvan wordt gepleit voor een benadering die meer aandacht besteedt aan de historisch-(geo)politieke aspecten van deze instellingen en het gebruik dat daarvan gemaakt wordt.

Hoofdstuk 3 is gewijd aan de verdere uitwerking van de vraagstelling en de opzet van het onderzoek. De weergave van het onderzoeksmateriaal dat is verzameld om de gestelde vragen nader te belichten krijgt zijn beslag in twee hoofdstukken. In hoofdstuk 4 komen drie Nederlandse bedrijfstakken aan de orde: de kunststofverwerkende industrie, het wegvervoer en de bouwnijverheid. De internationale vergelijking is te vinden in hoofdstuk 5. Daar worden Duitse en Belgische kunststofverwerkende bedrijven en aannemersbedrijven in de bouwnijverheid onderling en met de Nederlandse bedrijven vergeleken.

In hoofdstuk 6 worden de belangrijkste conclusies samengevat en van een nabeschouwing voorzien. 


\title{
HOOFDSTUK 2
}

\section{Statelijke rechtspraak:}

\author{
alleen antwoord op \\ maatschappelijke behoeften?
}

In de sociaal-wetenschappelijke bestudering van de gerechtelijke praktijk heeft het onderzoek naar het 'beroep op de rechter' en andere vormen van 'geschillenbehandeling' een belangrijke plaats ingenomen.. De theoretische en empirische aandacht voor dit onderwerp heeft in de periode tussen grofweg 1965 en 1985 in de rechtssociologische literatuur een gevestigde thematiek doen ontstaan. ${ }^{1}$

In de bedoelde literatuur zijn - met enige goede wil - enkele motieven te onderscheiden. Het zijn motieven in een dubbele betekenis: thema's van en tegelijk ook beweegredenen voor onderzoek. Deze motieven vertonen voorts een zekere verwantschap met een bepaald - overigens niet altijd expliciet gemaakt - beeld van de maatschappelijke rol van rechtspraak. Het is hier van belang om aan deze thema's en voorstellingen enige aandacht te besteden, niet zozeer met de bedoeling om een uitputtend overzicht te geven van deze literatuur, maar meer om ten opzichte van deze coördinaten een eigen invalshoek te schetsen. Deze plaatsbepaling is van belang om duidelijk te maken dat dit onderzoek niet per se in het verlengde staat van één van de gevestigde motieven en de daarbij behorende rechtssociologische optieken, al is het natuurlijk wel schatplichtig aan deze literatuur als geheel.

De traditionele rechtssociologische benaderingen van rechterlijke instanties en procederen hebben - ondanks alle verschillen - bij nadere beschouwing een bepaalde eenzijdigheid gemeen, die naar ik meen toe is aan herziening. Waaruit deze eenzijdigheid bestaat zal hierna worden aangegeven. Daarbij worden enkele

I Zie voor een overzicht van de literatuur uit deze periode Galanter (1986) Adjudication, litigation, and related phenomena. 
voorbeelden gegeven van aspecten van rechterlijke instellingen en procederen, die tot dusverre ten onrechte onderbelicht zijn gebleven.

\section{Verschillende motieven}

$\mathrm{Er}$ is in de rechtssociologische literatuur vrij grote overeenstemming aan te treffen over de vraag waar het bij rechtspraak (dat wil dan vooral zeggen: burgerlijke rechtspraak) 'om te doen' is. Gerechtelijke instanties houden zich met name bezig met het beslechten of behandelen van conflicten of geschillen. Deze eensgezindheid is overigens ten dele schijn, omdat - zoals hieronder zal blijken - achter de gemeenschappelijke noemer van de 'geschilbehandeling' nogal uiteenlopende opvattingen schuilgaan over de maatschappelijke rol van rechtspraak en min of meer verwante instellingen.

De verschillen tussen de diverse benaderingen zijn in hoofdzaak te herleiden tot een combinatie van enerzijds de kenmerken van de sociologische (en soms rechtstheoretische) traditie waarin wordt gewerkt en anderzijds het doel dat men met het onderzoek beoogt te dienen. De hieronder volgende indeling betreft - uiteraard enigszins gestileerde - trends in de literatuur. Het gaat niet om elkaar in de tijd opvolgende trends, maar om min of meer parallel ontwikkelde benaderingen. $^{2}$

\subsection{Technocratisch denken}

In een gedeelte van de literatuur overheerst een technocratische optiek. Ze is aan te treffen in verhandelingen waarbij de vraag wordt gesteld of de rechterlijke organisatie naar behoren is toegerust om haar maatschappelijke taak te vervullen. Enkele voorbeelden kunnen het motief illustreren.

Zo signaleerde bijvoorbeeld Aubert aan het eind van de jaren zestig ontwikkelingen die er zijns inziens op duidden, dat in Noorwegen de betekenis van recht en juristen in het algemeen en van rechtspraak in het bijzonder aan het afnemen was. ${ }^{3}$ Wat de rechtspraak betreft gaf de verminderde groei - over een periode van 150 jaar - van het aantal rechters en de aantallen behandelde zaken naar zijn be-

2 De trends zijn ook niet ten opzichte van elkaar gesloten. Soms ook zijn elementen van verschillende trends in één bron aan te treffen. Cf. de typologie van Trubek (1990) Back to tbe futurr, p. 24 c.v. $\mathrm{Hij}$ is zo verstandig geen namen te noemen.

3 Aubert (1969) Law as a ang of nsobing conffacts. 
vinding blijk van stagnatie. ${ }^{4} \mathrm{Hij}$ beschouwde de rechterlijke functie (in ieder geval wat de civiele rechtspraak betreft) als een vorm van gespecialiseerde dienstverlening aan de maatschappij. De beschreven ontwikkeling was naar zijn mening vooral te begrijpen als een indicatie van de afnemende behoefte aan de rechterlijke dienstverlening. Ter verklaring van deze ontwikkeling wees hij op de rechterlijke werkwijze: de rechter hanteert traditioneel een beslissingsmodel waarin hij uitmaakt wie van de partijen 'wint' en wie 'verliest'. Aubert meende een toenemende behoefte te bespeuren aan een beslissingsmodel waarbij betrokkenen via onderhandelingen op een compromis trachten uit te komen.

Een andere ontwikkeling werd voor Amerika gesignaleerd door Friedman en Parcival. ${ }^{5} \mathrm{Zij}$ constateerden op grond van historisch dossieronderzoek, dat de gerechten in eerste aanleg die zij hadden onderzocht, zich in de loop van tachtig jaar steeds minder met contradictoire zaken en steeds meer met administratieve routinezaken waren gaan bezighouden. Verontrust vroegen zij zich af:

"what has society gained and lost, as an ancient structure of decision passes into history?" 6

Tot de jaren ' 70 klonken er meer van dergelijke geluiden over het wegkwijnen van de rechtspraak, ook in de Verenigde Staten. ${ }^{7}$ Daarna sloeg de stemming radicaal om en richtte de aandacht zich juist op klachten over de explosieve groei van het aantal aanhangig gemaakte procedures en de overbelasting van de gerechtelijke instanties. ${ }^{8}$ Er werd in die tijd gesproken van een 'crisis of the courts'. Het typeren van een situatie als een 'crisis' is vaak de opmaat voor een voorstel voor interventie. Zo ook hier. De gedachten gingen in dit verband voornamelijk in twee richtingen. In de eerste plaats werd gepleit voor onderzoek naar de mogelijkheden om de 'efficiency' van de rechterlijke organisatie te vergroten en in de tweede plaats zou een deel van de werklast naar daarvoor meer geëigende vormen van geschilbehandeling kunnen worden afgestoten ter ontlasting van de gerechten.

Op deze discussies is destijds aangesloten door het bekende 'civil litigation re-

4 Voor Nederland kon een dergelijke ontwikkeling overigens niet worden bevestigd, integendeel. Schuyt \& Jettinghoff (1981) De sociale kaart van Nederland, p. 239 e.v.

5 Friedman \& Percival (1976) A tale of two courts.

6 Ibid., p. 301.

7 Cf. Galanter (1983) Reading the landscape of disputes, p. 9.

8 Ibid., p. 6 e.v.

9 Trubek (1981) Studying courts, p. 491.9

10 Rosenberg (1981) Civil justice research. 
search project' van de Universiteit van Wisconsin. ${ }^{11}$ Bij de opzet van dit project werd met zoveel woorden gesproken over de geschilbeslechtende functie van civiele gerechten. De toename in het beroep op de rechter zou er op wijzen dat het publiek zich daarvoor tot het gerecht wendt. Vervolgens werd geconstateerd, dat de gerechten blijkbaar moeite hebben aan de toegenomen vraag tegemoet te komen en dat alternatieve vormen van geschilbeslechting mogelijk een oplossing konden bieden. Denken over alternatieven werd daarbij niet alleen beschouwd als interessant vanwege overbelasting, maar ook vanuit een oogpunt 'geschiktheid en effectiviteit'. Dit laatste punt had - blijkens de eindrapportage - vooral betrekking op de vraag of het niet mogelijk zou zijn verschillende typen geschillen te laten behandelen door de daarvoor meest geëigende instantie. Er werd destijds van verschillende kanten gesuggereerd dat rechters bepaalde typen geschillen beter aan andere instanties met andere behandelingsmethoden konden overlaten. ${ }^{12}$

De technocratische geest die in deze optiek doorklinkt vertoont verwantschap met wat Hoekema de 'instrumenteel-functionalistische' benadering heeft genoemd. ${ }^{13}$ Aan de door deze invalshoek geïnspireerde literatuur over geschilbeslechting en het beroep op de rechter liggen enkele vooronderstellingen ten grondslag, waarvan er sommige duidelijk verwantschap vertonen met de functionalistische traditie.

Dat is allereerst het geval met de vaak impliciete notie dat conflicten en geschillen riskante sociale verschijnselen zijn. Volgens het structuur-functionalisme steunt sociale integratie in belangrijke mate op normatieve consensus. Nonconformiteit en conflicten zijn in deze optiek verschijnselen die desintegrerend kunnen werken en derhalve beheerst moeten worden. ${ }^{14}$ In de kritiek op het onderzoek van Trubek c.s. is dit punt - zoals nog zal blijken - meermaals op de korrel genomen. In de tweede plaats wordt rechtspraak in deze benadering uitdrukkelijk gekenschetst als een maatschappelijke instelling die een belangrijke rol vervult in het beslechten van conflicten en het bevorderen van normatieve inte-

11 Law \& Society Review (1980-1981) Special issue on dispute processing and civil litigation.

12 Trubek, t.a.p., p. 492.

13 Deze benadering kenschetste hij als uitgaande van de verwachting dat het mogelijk is "de kennis van externe relaties tussen recht en andere sociale verschijnselen te gebruiken om het recht waar mogelijk te beschouwen en te benutten als instrument voor een effectief en legitiem overheidshandelen." Hoekema (1985) Stromingen in de Nederlandse rechtssociologic, p. 31.

$14 \mathrm{Er}$ wordt wel rekening gehouden met de mogelijkheid van conflicten, maar dan gaat het er vooral om dat de sociale orde er niet in geslaagd is de doelstellingen van individuele leden op de collectieve waarden af te stemmen, "a beginning point which leads, as it did in Durkheim, straight to the view that dissent (crime, rebellion, revolution) is to be conceptualised as deviance, seen as lack of motivational commitment to consensual norms." Giddens (1976) New rules of seciological method, p. 95. 
gratie. Als mocht blijken dat rechtbanken in de vervulling van die taak (door afnemende of juist door te grote vraag) niet meer voldoen, dan is er een probleem en zal moeten worden voorzien in andere (alternatieve) voorzieningen, die mogelijk beter op de bestaande behoefte zijn toegesneden. Een derde veelal impliciete vooronderstelling, die waarschijnlijk ook van functionalistische origine is, betreft de rol van de staat. Er wordt van uitgegaan dat de behoefte aan voorzieningen voor geschilbehandeling qua aard en omvang vanuit de samenleving wordt gedefinieerd. De staat voorziet in de behoefte aan conflictbeslechting, maar hij handelt daarbij slechts als een soort dienstverlener. ${ }^{15}$

\subsection{Sociale hervorming}

Er is nog een ander motief in de literatuur aanwezig dat op verschillende punten de tegenvoeter van het voorgaande motief vormt. Wat deze benadering kenmerkt is, dat juridische instellingen - waaronder de gerechten - worden bevraagd op hun maatschappelijke neutraliteit: zijn het instellingen die een 'bias' hebben voor de gevestigde orde en belangen of bieden ze ook mogelijkheden voor de emancipatie van achtergestelde groepen? Het is er in deze maatschappijkritische optiek om te doen voor achtergestelde groepen gelijkberechtiging te realiseren en vooral ook gelijke effectuering van bestaande rechten. De strijd om de burgerrechten en de 'war on poverty' die zich in de Verenigde Staten hebben gemanifesteerd zijn daarbij inspiratiebronnen geweest. Ook in de West-Europese verzorgingsstaten kon het bestaan van ernstige manco's in dit opzicht worden vermoed. Ten aanzien van deze problematiek is het de taak van onderzoek na te gaan of de bedoelde instanties die mogelijkheden bieden; en voor zover dat niet het geval mocht zijn, belemmerende factoren op te sporen, opdat ze kunnen worden geruimd. Termen als "civil justice and the poor", "access to justice", "de weg naar het recht" en "Mobilisierung von Recht", geven aan waarom het in deze studies te doen is. ${ }^{16}$

In dit deel van de literatuur komen verschillende theoretische achtergronden samen. Een deel van de Amerikaanse literatuur wordt door Trubek in verband gebracht met de rechtstheoretische traditie van het 'Legal Realism'. De Amerikaanse rechtssociologie van de "Law and Society"- beweging ziet hij als een directe

15 Dit ligt in het verlengde van de neiging in de functionalistische traditie om de staat als een extensie, een uitvoerend orgaan van de samenleving te zien. Politieke macht is in deze voorstelling een middel om collectieve doelen na te streven en gebaseerd op consensus. Cf: Giddens (1977) Studies in social and political theory, p. 346.

16 Carlin, Howard en Messinger (1966) Civil justice and the poor, Cappelletti en Garth (1978) Access to Justice; Schuyt, Groenendijk en Sloot (1976) De weg naar bet recht; Blankenburg en Reifner (1982) Rechtsberatung. 
erfgenaam van deze empirisch georiënteerde rechtstheorie. Bij deze 'postralisten' meent hij de neiging te ontwaren om de normatieve grondslagen van herechtssysteem te beschouwen als duidelijk omlijnbare begrippen: "justice was viwed as a determinate concept with fixed meaning". ${ }^{17}$ In dit perspectief is het de hitische taak van de rechtssociologie de praktische verwezenlijking van de centra waarden van het recht te onderzoeken. Daarbij zou impliciet worden veronersteld dat, wanneer de discrepantie tussen theorie en praktijk door onderzoek enmaal zou zijn aangetoond, het wegwerken van die discrepantie niet zou kunneruitblijven. Maar er zijn ook nog andere inspiratiebronnen gesignaleerd.

Op verschillende punten wijkt deze benadering af van die van de hirboven genoemde vooronderstellingen van de bestuurlijke benadering. Een beangrijk verschil is dat conflicten niet per se gezien worden als bedreigend voor disociale integratie zolang er maar geen geweld aan te pas komt. Dan worden ze elfs beschouwd als onmisbaar voor de verbetering van maatschappelijke verhoulingen. Typerend is daarbij ook dat niet 'conflict' het kernbegrip is, maar 'rehtsprobleem'. Dit is een direct uitvloeisel van een ander verschil: de juridischerraktijk wordt nıét benadérd vanut dé optıek'van jündišsche ınstellïngen, maar nadrukkelijk vanuit het 'consumenten perspectief. ${ }^{19} \mathrm{Het}$ in kaart brengen van de problematiek van achtergestelde groepen kan aangeven waar de gevestigde definities van de situatie tekort schieten, onafhankelijk van het feit of er in individuele gevallen manifeste conflicten ontstaan. Een derde verschil is dat de kenmerken van de 'partijen' hier wel van wezenlijk belang zijn. Ze worden vooral gecategoriseerd als representanten van bepaalde sociale strata: sociale stratificatie staat hier centraal. Het accent ligt wel op (groepen) burgers, maar ook organisaties komen uitdrukkelijk naar voren als prominente (en dominante) juridische actoren. Een laatste kenmerk van deze benadering is dat ook hier de staat niet als onafhankelijke actor,

17 Trubek (1988) The handmaiden's revenge p. 119

18 De geschetste benadering komt in grote trekken overeen met wat Hoekema in de Nederlandse rechtssociologie het 'idecel functionalisme' heeft genoemd. Darbij stond bij hem vooral het symbolisch interactionisme voorop. In deze benadering is het recht een emancipatoire rol toebedacht. Het heeft als opdracht in fora te voorzien waar voorstellen voor herdefinièring van de zin van sociale instituten aan een open dialoog onderworpen kunnen worden. Met de 'openheid' van de dialoog wordt bedoeld. dat de dialoog niet doorkruist mag worden door de machtsverhoudingen, die buiten het forum gelden. Rechtspraak kan als een dergelijk forum beschouwd worden. Onderzock vanuit deze optiek is er vooral op gericht na te gaan in welke mate de instelling in kwestie zijn opdracht of zin kan verwezenlijken en welke factoren daarop van invloed zijn. Wat het recht betreft gaat het er vooral om "te laten zien welke elementen van de sociale structuur groepen mensen verhinderen om an de dialoog deel te nemen" Hoekema, (1985) Stromingen, p. 35.

19 E.g. Schuyt, Groenendijk en Sloot (1976) De weg. p. 48. 
met een eigen agenda, naar voren komt. De agenda van de verzorgingsstaat is min of meer vastgelegd in beginselen en wettelijke bepalingen. Maar goede bedoelingen moeten geen goede bedoelingen blijven. Onderzoek moet barrières voor het effectueren van rechten en het participeren in dialogen over vernieuwingen aan de kaak stellen. In een verzorgingsstaat zal de overheid een appèl om waar nodig aan de onderzoeksresultaten de nodige consequenties te verbinden moeilijk naast zich neer kunnen leggen. Rechtspraak voorziet in deze optiek niet zozeer in een maatschappelijke behoefte of noodzaak, maar heeft een opdracht, een maatschappelijke roeping.

\subsection{Algemene theorie.}

Een derde motief is in belangrijke mate van rechtsantropologische origine. Bij rechtsantropologisch veldwerk heeft zich onder meer geschilbehandeling als een veelbelovende focus voor onderzoek aangediend. ${ }^{20}$ Met name van deze thematiek werd verwacht dat het zich ook goed zou lenen voor het slaan van een brug naar onderzoek in moderne samenlevingen.

Een belangrijke rol is daarbij gespeeld door een naoorlogse generatie Amerikaanse juristen, die in het kader van de 'recht en ontwikkeling'-projecten naar Latijns-Amerikaanse en Afrikaanse landen zijn uitgezonden. Dit ontwikkelingswerk werd ideologisch gedragen door de moderniseringsthese die poneerde dat introductie van westerse instellingen de economische vooruitgang in onderontwikkelde samenlevingen konden stimuleren. De notie, dat ook Westers recht daarbij een rol in de ontwikkeling van de jonge nationale staten zou kunnen spelen, werd onder meer ontleend aan Weber, die het belang van het rationele recht en de ontwikkeling van het kapitalisme heeft gethematiseerd. ${ }^{21}$ Eén van de oorzaken van het falen van deze onderneming is geweest dat het bestaande 'volksrecht' zich vaak niet opzij liet zetten. Bij hun terugkeer naar de Westerse juridische faculteiten zijn deze ervaringen voor betrokkenen een belangrijke bron van inspiratie geworden. Daarbij zijn vooral twee ervaringen als leidraad gebruikt: de bruikbaarheid van de geschilthematiek in premoderne samenlevingen en de confrontatie met de invloed van niet-statelijke gedragsregels binnen sociale verbanden. Daarmee kon worden aangehaakt bij thema's - zoals effectiviteit van wetgeving en gerechtelijke (en buitengerechtelijke) geschilbehandeling - die ook vanuit andere invalshoeken in het Westen in de belangstelling waren komen te staan.

20 Een aardige beschrijving geeft: Kidder (1983) Connecting law and society, p. $147 \mathrm{ff}$.

21 Cf: Tamanaha (1995) The lessons of law-and-development studies. 
Onderdeel van dit rechtsantropologisch program is geweest het op en hoger plan brengen van de rechtssociologische theorie. In dat kader zijn enele pogingen ondernomen tot het ontwerpen van een universele theorie naar steng natuurwetenschappelijk model. De algemene toon is daarbij vooral gezt door Black. ${ }^{22}$ Voor de onderhavige thematiek kunnen met name de aanzetten ot algemene theorievorming van Abel en Griffiths worden genoemd. ${ }^{23}$ Het jurilische is in deze stroming vooral een bepaald type gedrag dat gericht is op socialecontrole. ${ }^{24}$ Ook rechtspraak staat zo in het teken van sociale controle en wel al een gespecialiseerde vorm daarvan. $\mathrm{Er}$ is wel getracht het begrip sociale control te ontdoen van de uit het structuur-functionalisme afkomstige connotaie met deviantie en ordehandhaving, maar volgens kritische commentaren is heniet gelukt van deze erfenis los te komen. ${ }^{25}$

De term 'geschil' is met name door deze stroming in zwang gebrach. Het is vanuit deze benadering - waarin sociale controle centraal staat - een biangrijk verschijnsel, omdat het gaat om gedragingen waarmee mensen elkaar 'torde orde roepen'.

Deze b'enadèring neemt voorts in enḱelé opzichíten atstand van dè andere benaderingen. De (in de eerstgenoemde optiek) gepostuleerde conflictoplossende functie van rechtspraak is vanuit deze invalshoek sterk gerelativeerd. ${ }^{26}$ Uit onderzoek is gebleken dat rechtspraak daarbij een meer bescheiden rol speelt dan in de traditionele zienswijze verondersteld wordt. Het merendeel van de geschillen, waarover men zou kunnen procederen, wordt nooit bij een rechtbank aanhangig gemaakt. Wat er bij de rechtbanken terechtkomt is maar het topje van een ijsberg. Alternatieve vormen van geschilbehandeling verzetten veel meer werk. Veel van wat rechtbanken doen lijkt bovendien niet op geschilbeslechting: vaak wordt er geen volledig proces gevoerd en er wordt lang niet altijd een rechterlijke beslissing genomen.

Ook is de mogelijkheid om via rechtspraak maatschappelijke hervormingen te bewerkstelligen (zoals volgens het tweede motief is bepleit) in twijfel getrokken. ${ }^{27}$ De mogelijkheden en voordelen die de officiële rechtsinstellingen te bieden heb-

22 Black (1976) The behavior of law.

23 Abel (1974) A companative theory of dispute institutions in society, Griffiths (1983) The general theoryof litigation - a first step. ${ }^{4}$

24 Griffiths (1983) t.a.p., p. 156.

25 Van den Bergh (1986) Over een theorie van sociale controle, p. 377; Pieterman (1993) Rechtoseciologie tuosen sociologie en rechtowetenschap, p. 20.

26 Galanter (1981) Justice in many rooms.

27 Galanter (1974) Why sbe haves, "The "Haves" paper was a challenge to the judicial triumphalism that was recieved wisdom of the progressive wing of the U.S. legal academy.", aldus Galanter in een terugblik (1999) Farther along, p. 1115. 
ben worden vooral benut door de 'haves', en de mogelijkheden om daar iets aan te veranderen zouden beperkt zijn.

Voorts wordt - indachtig de antropologische ervaringen - de invloed van statelijke regulering sterk gerelativeerd. Als bezwaar is naar voren gebracht, dat in andere rechtssociologische stromingen statelijk recht teveel centraal is geplaatst; daar is sprake van wat men noemt 'legal centralism'. ${ }^{28}$ Tegenover dit juridisch centralisme van de benaderingen die statelijk rechtsinstellingen en hun beslissingen cen centrale plaats toekennen, is het 'rechtspluralisme' in stelling gebracht. Volgens deze benadering is de zelfregulering en informele sociale controle van de 'semi-autonome sociale velden' waarin het sociale leven zich voltrekt een belangrijk(er) gegeven en bijvoorbeeld medebepalend voor het effect van wettelijke regulering.

Overigens is het ontstaan van gespecialiseerde instanties (zoals statelijke organisaties) betrekkelijk onuitgewerkt gebleven. Er wordt veelal volstaan met de aanduiding van factoren als 'arbeidsverdeling' en 'relational distance'. ${ }^{30}$

\section{Kerend tij}

In de loop van de 80 -er jaren begint zich in de rechtssociologie een heroriëntatic te voltrekken. Abel wordt wel genoemd als de klokkenluider. Als redacteur van de Law \& Society Review had hij de indruk gekregen dat de routine de overhand had gekregen. ${ }^{31}$ Het probleem was volgens Abel, dat de rechtssociologen hun onderzoeksvragen teveel hadden ontleend aan hun onderzoeksobject. Zo langzamerhand was toch wel duidelijk dat juridische instellingen vaak niet de effecten sorteren die ervan worden verwacht. Deze werkwijze was goed voor de opbouwfase, maar nu werd het tijd voor een andere koers. Aldus Abel.

De heroriëntatie die daarop volgde (of mogelijk al latent gaande was) had waarschijnlijk ook te maken met meer algemene ontwikkelingen. Er was eind 70-er jaren een economische recessie gaande, met aanzienlijke inflatie en werkloosheid. Het politieke klimaat maakte een zwenking naar rechts en bracht de Reagan-Thatcher revolutie die een heropleving van het marktdenken in de politiek en

28 Galanter (1981) Justice in many rooms, p.1.

29 Griffiths (1979/1986) What is legal pluralism?, p. 38.

30 Abel (1974) A comparative theory, p. 237; Griffiths (1983) The general theory, p. 172.

31 [...] I sense that our field is running so smoothly along familiar tracks that the questions and answers have begun to sound a comfortable, but rather boring, "clackery-clack". Abel (1980) Redirecting social studies of law, p. 805. 
beleid bracht. De terugtred van de interventiestaat en het meer neoliberale politieke klimaat waren nu niet direct koren op de molen van de empirische sociologie. ${ }^{32}$

Voor een belangrijk deel kwam de heroriëntatie in de rechtssociologie neer op een wending naar theoretische perspectieven met een hoog abstractieniveau, hoofdzakelijk gericht op ideologiekritiek en rechtstheorie. Critical legal studies en (post)structuralisme zijn enkele van de stromingen die zich hebben gevoegd bij wat er al was. ${ }^{33}$

De onderhavige thematiek verloor door deze ontwikkelingen de centrale plaats die het enige tijd had ingenomen. De sociologie van het recht zou zich meer moeten gaan richten op de juridische concepties, en zich niet meer moeten beperken tot een sociologie van rechtbanken en juristen. ${ }^{34}$ Deze kentering werd (achteraf gezien) min of meer aangekondigd door de zeer kritische commentaren die de publicatie van de onderzoeksresultaten van het "Civil Litigation Research Project" vergezelden. Een belangrijk deel van de kritiek richtte zich op de vooronderstellingen van het onderzoek en op wat de 'disputes industry' genoemd werd. Exemplarisch zijn de kritieken afkomstig van Kidder en Cain \& Kulcsar. ${ }^{35}$

Hun kritiek heeft zich vooral gericht op de aan het structureel-functionalisme ontleende assumpties, die ze in een groot deel van de toenmalige geschilliteratuur meenden te onderkennen. Als belangrijke impliciete noties van de geschiltheorie werden genoemd: enerzijds de gedachte, dat geschillen en conflicten opgelost moeten worden, omdat ze momenten van wanorde zijn; en anderzijds de notie, dat rechtbanken geschillen moeten beslechten, en als zij dat niet doen een andere instantie dat moet doen. Kidder vatte deze impliciete voorstellingen kernachtig samen als het 'hogedrukpanmodel':

"the paradigm likens society to a pressure cooker with dispute processing as relief valves preventing social catastrophe"

Hier is volgens Cain en Kulcsar sprake van een duidelijke affiniteit met een voorstelling van zaken die strookt met juridisch gedachtegoed:

"It is fundamental to legal ideology that law (a) resolves disputes, (b) deals with legally equal parties, and (c) benefits society by doing so. Law in this view is not just a form of social control, but a necessary and inevitable one in "advanced" societies." Maar tot de formulering van een alternatieve invalshoek is het niet gekomen. Met name het progressieve engagement heeft zich op andere onderwerpen gericht.

32 Cf. Bauman (1988) Is there a postmodern sociology?

33 Een overzicht biedt: Munger (1993) Sociology of law for a postliberal society.

34 Aldus de kernachtige samenvatting van Nelken (1998) Blinding insights?. p. 413.

35 Kidder (1981) The end of the noad? Cain \& Kulcsar (1982) Thinking disputes.

36 Kidder, t.a.p., p. 718

37 Cain \& Kulcsar, t.a.p., p. 393 
Voor de meer op de praktijk en algemene theorie georiënteerden lijkt het thema (en soms ook de functionalistische benadering, ondanks alle kritiek) aantrekkingskracht te houden. ${ }^{38}$ Ook al heeft de studie van het beroep op de rechter zijn centrale plaats in de rechtssociologisch theorie en empirie verloren, toch blijf het cen relevant (zij het niet per se het meest relevante) onderwerp. Het volgende is een poging die relevantic vanuit een andere rechtssociologische invalshoek te omschrijven.

\section{Staatsvorming als invalshoek}

Een gemeenschappelijke trek van de in de vorige paragraaf genoemde benaderingen is, dat de vorming van rechtsprekende instanties en het gebruik dat ervan gemaakt wordt, vooral begrepen wordt in termen van een (hetzij systematische, hetzij met de belangen van bepaalde groeperingen verbonden) maatschappelijke behoefte of noodzaak. In de rechtssociologie hebben deze zienswijzen tot dusverre het onderzoek op dit terrein in belangrijke mate gedomineerd. Wat in deze optiek vooral ontbreekt is het eigen perspectief van politieke actoren die rechterlijke voorzieningen 'aanbieden'. Zij lijken slechts in een soort dienstverlenende rol op te treden, zonder 'eigen' ambities. ${ }^{39}$

Dat is wel mogelijk in een benadering waarbij instellingen beschouwd worden als gepositioneerd in een netwerk van personen of organisaties die er iets van 'willen' en dat ook proberen gedaan te krijgen. Die wensen of eisen komen ten dele voort uit de (machts)positie die deze personen of groepen in dat netwerk bekleden. Tot dit netwerk dienen dan ook, naast de 'klanten', politieke actoren en actoren binnen of rond de instellingen zelf gerekend worden. Deze benadering is verwant met elementen uit de 'perspectivische' benadering van instituten die bij Elias is aan te treffen. Hij stelt dat alle betrekkingen tussen mensen een 'perspectivistisch' karakter hebben:

38 Zie bijvoorbeeld de Nederlandse studies van: Ippel (1989) Reacties op rechesbescherming, Niemeyer (1991) Geschillen over bouwplannen, Verkruisen (1993) Dissatisfied patients. Voorbeelden studies elders zijn: Merry (1990) Getting justice, Genn (1999)Paths so justice.

39 Een illustratief voorbeeld, ontleend aan Donner (1995) Hollen of stilstaan, p. 52. In een beknopte historische schets herleidt Donner de ontwikkeling van de rechtsstaat tot drie "maatschappelijke behoeften". Eén van die behoeften is "de behoefte om soeverein het geldend recht te kunnen aanpassen en te veranderen". In verband daarmee "ziet men de koninklijke rechtspraak ontstaan als antwoord op de behoefte aan sturing en verandering in het belang van de publieke zaak". Onduidelijk blijft bij welke maatschappelijke geleding(en) die behoefte leefde. Bovendien wordt gesuggereerd dat de vorst bij deze ontwikkeling geen eigen ambities had. 
"iedere tweezijdige betrekking $A B$ [omvat] eigenlijk twee te onderkennen betrekkingen, $n l$. betrekking $A B$ gezien vanuit het perspectief van $A$, en betrekking $B A$, gezien vanuit het perspectief van $B$. Wanneer men begrippen hanteert die zelfs aan betrekkingen het karakter van statische objecten verlenen, is het moeilijk dit perspectivistisch karakter van alle menselijke betrekkingen recht te doen wederva ren. ${ }^{\text {sio }}$

Heel toepasselijk illustreert hij zijn zienswijze aan de hand van het begrip 'functie'. Als men zegt, aldus Elias, dat een instituut een bepaalde functie vervult voor de maatschappij, dan wordt verhuld, dat het bij sociale functies gaat om 'facetten' van betrekkingen en daarmee verdwijnt hun perspectivistisch karakter uit het zicht. Naar zijn opvatting hebben instituten vanuit de optiek van degenen die ze vormen op zijn minst ook een functie voor henzelf (wat hij noemt de 'ik-functie'). 4

Bij het zoeken naar een dergelijke benadering, die een alternatief kan bieden voor de syteem- en 'bottom-up' benaderingen van gerechtelijke instellingen, valt te leren van ontwikkelingen in de politieke sociologie met betrekking tot staatsvorming. Deze ontwikkelingen zijn relevant, omdat staatsvorming een vruchtbaar kader kan zijn voor het doorgronden van rechtsontwikkelingen. In dit verband is nog belangrijker dat zich in de politieke wetenschappen bij studie van de staat een interessante parallel heeft voorgedaan. Ook daar zijn lange tijd benaderingen toonaangevend geweest, die de staat duidden in het licht van de behoeften van 'de' samenleving of toonaangevende segmenten daarvan. Poggi heeft in dit verband de voornaamste politiek-theoretische tradities in twee categorieën verdeeld. ${ }^{42}$ Hij onderscheidt enerzijds een groep theorieën, die hij de 'society-centered' benadering van staatsvorming noemt. Tot deze benaderingswijzen rekent hij vooral de functionalistisch en de (neo)marxistisch georiënteerde theorieën. De overheid fungeert - volgens deze 'society-centered' benadering - als een dienend subsysteem dat in de behoefte aan sociale integratie van een samenleving voorziet, respectievelijk als een verlengstuk van economisch dominante groepe-

40 Elias (1971) Wat is sociologie?, p. 139.

41 Ibid., p. 140-141. Een vergelijkbare benadering is te vinden bij Garland (1990) Punishment, p. 282 e.v. Hij bepleit een benadering van 'social institutions' warbij complexiteit en overdetermination' voorop staan. Dat is noodzakelijk omdat: "institutions are the scenes of particular conflicts as well as being means to a variety of ends, so it is no surprise to find that each particular institution combines a number of often incompatible objectives, and organizes the relations of often antagonistic interest groups." (282). Ook de 'ik-functie' van Elias wordt niet vergeten: een sociale instelling vormt: "a kind of junction-point in the social field upon which a range of forces converge, as well as being a setting for its own particular norms and practices" (283).

42 Poggi (1990) The state, p. 86 e.v. 
ringen. In deze benaderingen komen de 'eigen' belangen van staatsinstellingen niet of onvoldoende aan de orde.

Interessant is voorts dat er voorstellen zijn ontwikkeld voor een andere invalshoek. Tegenover de "society-centered' benadering plaatst Poggi een 'statecentered' benadering van politieke organisatie die teruggrijpt op meer historisch geörienteerde sociologie. ${ }^{43}$ In deze literatuur is de staat een historisch specifiek verschijnsel. Dat wil zeggen dat het een vorm van politieke organisatie betreft, die in bepaalde opzichten uniek is voor een bepaalde periode en een bepaald gebied. De vorming van dit type politieke organisatie vindt zijn oorsprong in Europa. Het voorspel van deze ontwikkeling laat men wel aanvangen in de $11^{\mathrm{e}}$ eeuw, Maar pas de Vrede van Westfalen in 1648 wordt beschouwd als het moment, waarop definitief van de traditionele politieke eenheid van het Europese Christendom, overkoepeld door Keizer en Kerk, afscheid is genomen en regionale politieke eenheden, territoriale staten, de geopolitiek alleen zijn gaan beheersen. In deze politieke eenheden raakten feodale concepties en verhoudingen op de achtergrond en deden zich nieuwe opvattingen en relaties gelden. Als belangrijke kenmerken worden onder meer genoemd: de afbakening van een territorium, waarin een instantie (aanvankelijk de vorst, later de natie) de hoogste macht claimt, daarbij gesteund door een bestuursorganisatie.

De staat maakte aanspraak op een exclusief grondgebied, een zo goed mogelijk van de aanspraken van andere staten afgegrensd territorium. De techniek om dat met enige accuratesse te doen kwam in de tweede helft van de zeventiende eeuw tot ontwikkeling. Tot die tijd was het precies aangeven van grenzen vaak een probleem, zoals bijvoorbeeld bij het vaststellen van de termen van vredesverdragen. ${ }^{45}$ Binnen dit territorium claimden de vorsten de hoogste macht, soevereiniteit. In het internationale verkeer hield dit in, dat de ene staat geen zeggenschap had binnen het territorium van een andere. In het interstatelijk verkeer had een staat in dit opzicht alleen gelijken. Binnen het territorium evenwel had de vorst in beginsel geen gelijken. Een belangrijk onderdeel van het staatsvormingsproces is het vorstelijk streven geweest naar het verwerven van een aantal exclusieve bevoegdheden: in het bijzonder het monopolie op rechtmatige dwanguitoefening, de

43 Een aardige introductie tot deze benadering vormt: Held (1992) The development of the modern state. In het volgende is vooral een beroep gedaan op:: Poggi (1990) The state, Tilly (1990) Coencion, capital and European states, Spruyt (1994) The sovereign state and its competitors, Tilly \& Blockmans (1994) Cities and the rise of states in Europe, Held (1995) Democracy and the global order, Van Creveld (1999) The rise and decline of the state.

44 Cf. Poggi (1990) The state, p. 19 e.v.; Held (1992) The Development, p. 88; Van Creveld (1999) The rise, p. 1.

45 Er was eerder sprake van zone's van invloed; Van Creveld, t.a.p., p. 143 e.v. 
hoogste wetgevende macht en het monopolie op het heffen van belastingen. Rond deze taken vormde zich de kern van het bestuursapparaat.

De dynamiek van de ontwikkeling van deze vorm van politieke organisatie wordt vooral toegeschreven aan de competitieve verhouding tussen vorsten. De 'interne' dynamiek was voor een belangrijk deel te verklaren uit de aard van 'externe' verhoudingen. Met name oorlog wordt in deze historisch-sociologische benadering gezien als een voorname katalysator voor de vorming van de politieke organisatie, waarvan zich in West-Europa sinds de Late Middeleeuwen de eerste elementen aandienden, en die aan het eind van de zestiende eeuw van een naam werd voorzien. ${ }^{46}$ Het consolideren en zo mogelijk uitbreiden van hun rijk was een min of meer onvermijdelijke ambitie van de vorstelijke statenbouwers geworden: wie niet 'meespeelde' liep de kans onder de voet gelopen te worden. ${ }^{47}$ En omdat territoriale kwesties vooral ook op het slagveld werden beslist, was de capaciteit tot het voeren van een succesvolle oorlog van eminent belang.

Daarmee komt ook de institutionele logica van het staatsvormingsproces - zoals door Tilly gereconstrueerd - in beeld. Zowel voor het zich voorbereiden op oorlog als voor het daadwerkelijk voeren ervan, waren aanzienlijke (en naarmate feodale krijgsdiensten verder werden vervangen door huurlegers en tevens de militaire technologie voortschreed, steeds grotere) fortuinen nodig. De benodigde middelen werden grotendeels vergaard via eigen inkomsten van de vorst, belastingheffing en leningen. Organisatie van militaire capaciteit en de financiering daarvan zijn op grond van deze logica te beschouwen als primaire (en onderling samenhangende) activiteiten in het proces van staatsvorming. Rond deze activiteiten ontwikkelden zich ook de eerste elementen van de centrale bestuursorganisatic. ${ }^{48}$ De mate waarin men in staat was de middelen te mobiliseren die nodig waren om overeind te blijven in de steeds veeleisender oorlogen zou uiteindelijk beslissend zijn voor het 'eigen' overleven in de krijgszuchtige Europese politieke arena. Het streven van het politieke centrum was gericht op het behouden (en zo mogelijke versterken) van een positie in een spanningsveld tussen enerzijds 'externe' krachten, namelijk het handelen van opponenten in de geopolitieke arena, en anderzijds 'interne' krachten, namelijk van de maatschappelijke geledingen binnen het rijk, zoals adel, kerk en steden.

Teneinde de logistieke arbeid die staatsvorming vereist en de structurele tendenties die daarmee verbonden zijn samenhangend in beeld te brengen heeft Tilly staatsvorming getypeerd als een 'protectie'-arrangement. ${ }^{49}$ Daarbij wordt een

46 Ibid. p. 178.

47 Op deze positionele dwang wijst ook Elias (1982) Het civilisatieproces (II). p. 103.

48 Tilly (1990) Coercion, p. 96.

49 Tilly (1985) War making and state making as organized crime. 
staatsvormer gepresenteerd als een beschermer die zich opwerpt om het leven en goed van cliënten te vrijwaren van vijandelijkheden zowel van buiten als van binnen zijn protectiegebied. De beschermden dragen daarvoor een deel van hun productie af. Wil de beschermer deze positie behouden en de opbrengsten optimaliseren, dan zal hij zich van concurrenten binnen zijn beschermingsgebied moeten ontdoen. Dit arrangement zet de beschermer derhalve aan een aantal taken: (1) het voorbereiden en voeren van oorlog tegen externe rivalen, (2) het onderwerpen van mogelijke interne rivalen (3) de bescherming van interne cliënten tegen hun vijanden en (4) de extractie van de middelen en mensen die nodig zijn om deze activiteiten te verrichten. Wanneer deze taken veeleisender worden door bijvoorbeeld de groei van de omvang van het protectoraat of de verandering van oorlogstechnologie, kan een of andere vorm van administratieve arbeidsverdeling (bijvoorbeeld middels bureaucratisering) een belangrijke voorwaarde blijken voor succes. Ook impliceert dit proces het streven naar de zeer geleidelijk centralisatic van zeggenschap en monopolisering van dwangmiddelen en belastingen. Deze ambities hebben steeds in het teken gestaan van het vergroten van de capaciteit om - met zo min mogelijk tussenkomst van andere grootheden - middelen en mensen te mobiliseren voor het bijblijven in de geopolitieke wedijver.

Een opmerkelijk aspect van deze benadering is dat criminaliteit en politiek hier dicht bij elkaar komen te liggen. Het is dan ook niet toevallig dat 'protectie' een sinistere bijklank heeft. In het gunstigste geval zal de beschermer zijn dwangmacht alleen gebruiken om de aantasting van leven en goed van zijn cliënten tegen te gaan: in dat geval is zijn optreden legitiem en kan voor 'verdediging' en 'justitie' doorgaan. Maar, zoals Tilly opmerkt: "Someone who produces the danger and, at a price, the shield against it is a racketeer. ${ }^{50} \mathrm{Er}$ is altijd het risico, dat de beschermer bijvoorbeeld zelf de kans op oorlog vergroot en de crisis aangrijpt om extra mensen en middelen tot zijn beschikking te krijgen. Of hij kan ook zijn toevlucht nemen tot de directe toe-eigening. In dergelijke gevallen is er geen wezenlijk verschil met 'organised crime'. ${ }^{51}$ Opportunisme van de beschermer zal door

50 Ibid., p. 171.

51 De politieke geschiedenis getuigt meermalen van het feit dat dit niet slechts een theoretische mogelijkheid is geweest. Vorsten schrokken soms niet terug voor uiterst drastische methoden om hun schatkist te vullen. Een van de illustratieve casus vormt Philips IV (de Schone). Hij ontplooide tijdens zijn koningsschap (1285-1314) een grote militaire activiteit, en om die te financieren ging geen zee hem blijkbaar te hoog. Naast monetaire manipulaties (devaluatie) en het aanslaan van de geestelijkheid voor een buitengewone belasting (hetgeen resulteerde in een hooglopend conflict met de Paus, dat laatstgenoemde noodlottig werd), beproefde hij ook nog minder zachtzinnige methoden. Zo liet hij de berittingen van mensen van joodse en Lombardische origine confisceren, om ze vervolgens integraal te verbannen. Ook liet hij, bij wijze van definitieve schuldsanering, alle leden van de Orde der Tempeliers - die als de bankier van de koning fungeerde en bij wie hij in het 
effectief verzet van de beschermden gecorrigeerd moeten worden, als ze niet getiranniseerd willen worden. En waar de beschermer niet sterk genoeg is moet hij onderhandelen en concessies doen.

Aan de benadering van Tilly kan nog een ander element worden toegevoegd, dat wel bij andere schrijvers aan de orde komt. Zijn benadering accentueert vooral strategisch handelen binnen het interstatelijk kader. Het is vooral een wereld van realisme, opportunisme, effectiviteit. Interpretatiekaders of ideologie komen slechts zijdelings aan de orde. De focus op actie is verhelderend, maar geeft nauwelijks ruimte voor de invloed van conceptuele elementen. Dat is vanuit een rechtssociologische optiek een gemis. Want juist daarin lijkt de rol van recht en juristen van betekenis te zijn geweest. Door andere auteurs wordt die rol in het staatsvormingsproces overigens wel uitdrukkelijk onderkend. ${ }^{52} \mathrm{Bij}$ hen is het mobiliseren van mensen en middelen niet alleen een kwestie van 'grijpen wat je grijpen kunt'. Er werd veelal waarde gehecht aan het hebben van een geldige titel voor het effectueren van aanspraken, met of zonder gebruik van geweld. ${ }^{53}$

Dergelijke interpretatiekaders waren bijvoorbeeld van belang (en niet alleen voor de vorsten) omdat ze een vreedzame machtsoverdracht konden bewerkstelligen. Het 'beschermings-arrangement' kon op die manier geconsolideerd worden. Een voorbeeld zijn de dynastieke (erfrechtelijke) tradities en doctrines die lange tijd een rol hebben gespeeld bij vorstelijke machtsoverdracht. ${ }^{54}$ Maar vrede was daarmee uiteraard niet gegarandeerd. Want dynastieke aanspraken waren menigmaal betwistbaar (of manipuleerbaar) en bovendien bleven reële krachtsverhoudingen van gewicht. Door het ideologische element is het proces van staatsvorming niet uitsluitend een kwestie geweest van politieke of economische macht, maar ook van definitiemacht, de strijd om 'geldige' conceptualiseringen. En daarin was een deel van de expertise en dus ook de maatschappelijke kans van de universitair geschoolde juristen gesitueerd. Zij konden daarbij vooral ook putten uit de schatkamer van het 'geleerde recht' en de politiek-filosofische erfenis van de klassieke wereld. Soms diende de introductie van 'nieuwe' concepten tegenstellingen te overbruggen en bereikte compromissen te bezegelen. Maar ook konden ze de wens weerspiegelen om de vorst tot een overheersende politieke factor te maken.

Een voorbeeld van het eerste is de notie dat de macht van de vorst strekt ter behartiging van het 'algemeen belang', het belang van het rijk, en bij implicatie der-

krijt stond - na een schijnproces terechtstellen. Cf. Volkmann (1997) Bien connaitre, p. 60.

52 Daarvoor biedt het werk van bijvoorbeeld Poggi en Spruyt meer aanknopingspunten. Dit punt wordt met name geaccentueend door Stuurman (1993) Duizend jaar, p. 84 e.v..

53 Poggi, t.a.p., p. 103.

54 Kratochwil (1995) Sovereignty as dominium, p. 31. 
halve niet alleen zijn particuliere belang. ${ }^{55}$ Met dit begrip werd een beperking van de bevoegdheden van de vorst tot uitdrukking gebracht. De vorst had te bepalen wat het algemeen belang in concreto inhield, maar hij moest zich wel kunnen verantwoorden tegenover magnaten, prelaten en steden, als hij aan hun rechten wilde raken; dat wil zeggen: hij diende zijn handelen te kunnen rechtvaardigen door aannemelijk te maken dat zijn initiatieven of eisen noodzakelijk waren in het welzijn van het rijk. Voorbeelden van het laatste vormen de introductie van de conceptie van de soevereine wetgever van Bodin en de "Artificiall Man" van Hobbes, constructies voor het samenbrengen van wetgevende en bestuurlijke bevoegdheden in én hand, opdat (na een chaotische periode van godsdienstoorlogen) een rechtmatige respectievelijk een daadwerkelijke orde hersteld en gehandhaafd zou kunnen worden. ${ }^{56}$

Deze conceptuele kant van staatsvorming brengt ons bij een kenmerk van de staat dat door sommige van de genoemde schrijvers over staatsvorming benadrukt wordt: de conceptie van de staat als een fictief lichaam, een publieke rechtspersoon, onafhankelijk van vorst en zijn onderdanen. ${ }^{57}$ Deze fictie verklaart het wonderbaarlijk aanpassingsvermogen van de staat. Dankzij deze voorstelling van zaken kon de soevereine macht in de loop der eeuwen verschoven worden van de vorst naar het parlement, en kon de staatsbureaucratie geleidelijk de andere 'functies' van de staat gaan overheersen, zonder dat de instelling als zodanig desintegreerde.

Het proces van staatsvorming heeft zich volgens Tilly niet overal overeenkomstig een identiek traject voltrokken. Daarbij zijn met name de steden van grote invloed geweest. Tilly heeft op basis van het onderscheid tussen dwang (belastingheffing) en kapitaal (lening) drie trajecten van staatsvorming in Europa onderscheiden. ${ }^{58}$ In Rusland ziet hij een voorbeeld van het 'dwangintensieve' patroon van monarchieën met een territorium zonder veel kapitaalkrachtige steden.

55 Post verwijst in het verband van "public welfare" naar de aan het Romeinse publiekrecht ontieende begrippen "urilitas publica" en "status regni". Post (1963) Law and politics, p. 60.

56 Van Creveld (1999) The rise, p. 176 e.v.

57 cf. Held (1995) Democracy, p. 38 e.v.; Van Creveld (t.a.p., p. 1) maakt dit element tot cen centraal onderdeel van zijn definitic van de staat als een "corporation in the sense that it possesses a legal persona of its own, which means that it has rights and duties and may engage in various activities as if it were a real, flesh-and-blood, living individual. The points where the state differs from other corporations are, first, the fact that it authorizes them all but is itself authorised (recognised) solely by others of its kind; secondly, that certain functions (known collectively as the attributes of sovereignty) are reserved for it alone; and, thirdly, that it exercises those functions over a certain territory inside which its jurisdiction is both exclusive and all embracing." 58 Tilly, t.a.p., p. 132 e.v.; vgl. minder schematische benadering bij: Spruyt (1994) The Sovereign State, p. 77 e.v.; Van Caenegem (1988) Publiekrecht, p. 68 e.v. 
Daarnaast, in het westen, wijst hij op een stedenband - lopend van de Lage Landen tot in Italië - met een 'kapitaalintensief 'patroon, waarin stadstaten, steden-liga's (Hanze) en kleine federaties gevormd werden. Het waren hier vooral steden die sterk genoeg waren om het zonder een sterk staatsverband te stellen. Aan weerszijden van de stedenband tenslotte een mengvorm van 'capitalized coercion', territoriale monarchieën die erin slagen de kapitaal genererende capaciteiten van steden ten eigen bate te exploiteren. Uiteindelijk zouden de monarchieën met 'gekapitaliseerde dwang' andere politieke formaties grotendeels van het toneel doen verdwijnen, omdat ze volgens Tilly het meest effectief waren in het mobiliseren van de voor internationale vijandelijkheden vereiste mensen en middelen. ${ }^{59} \mathrm{Zij}$ ontwikkelden het institutionele substraat voor de nationale eenheidsstaten van de negentiende en de twintigste eeuw.

In de geopolitieke arena ontstond na een periode van uitputtende en zeer gewelddadige oorlogen in Europa in de zeventiende eeuw een verstandhouding die het 'Westfaalse model' wordt genoemd en als volgt is getypeerd:

"It depicts the emengence of a world community consisting of sovereign states which settle their differences privately and often by force; which engage in diplomatic relations but otherwise minimal cooperation; which seek to place their own national interest above all others; and which accept the logic of the principle of effectiveness, that is the principle that might eventually makes right in the international worldappropiation becomes legitimation.

Deze trekken zullen de internationale verhoudingen tot in de twintigste eeuw tekenen. Elke staat in deze 'gemeenschap' claimde het hoogste centrale gezag binnen de landsgrenzen.

De zojuist geschetste benadering van staatsvorming heeft enkele aantrekkelijke aspecten. In de eerste plaats is er meer aandacht voor de zelfstandige betekenis van de politieke processen in de geopolitieke arena. Dat is winst ten opzichte van concepties van 'samenlevingen' als systemen of organismen, die zich in hoofdzaak ontwikkelen onder invloed van zelfgegenereerde impulsen. Moderne westerse 'staats-samenlevingen' zijn hier geen vanzelfsprekende sociale eenheden waarvan de wording te verklaren is uit een zich volgens een bepaalde algemene logica - bijvoorbeeld de druk van bevolkingsaanwas en economische modernisering - afwikkelende evolutic. $\mathrm{Ze}$ verschijnen hier ook als producten van een historisch specifiek proces, namelijk de onderlinge competitie in West Europa (vanaf de twaalfde eeuw) tussen diverse typen politieke formaties en de daarmee samenhangende 'interne' machtsstrijd tussen maatschappelijke geledingen die aan-

$59 \mathrm{Cf}$. de kritick op deze positie van Hobson(2000) The statte and international relations, p. 184. 60 Held (1992) Development, p. 86. 
spraak maakten op zeggenschap. De nationale eenheidsstaten die zich in de negentiende eeuw aftekenen worden vooral gezien als het contingent resultaat van dit historisch proces.

In de tweede plaats kan het accent op processen als oorlog en centralisering van dwangmacht, als wezenlijke elementen in het staatsvormingsproces, een belangrijke correctie aanbrengen in het beeld van de staat als een in beginsel goedaardige en dienstbare instantie, een beeld dat in de rechtssociologie soms cen impliciet uitgangspunt lijkt. Het is alsof het 'sociale' gezicht van de huidige verzorgingsstaten het element van dwangmacht vrijwel uit het beeld heeft gedrongen. ${ }^{11}$ Terwijl volgens het cijferwerk van Mann het niet-militaire takenpakket van de staat pas in de tweede helft van de negentiende eeuw in kwantitatief opzicht het militaire is gaan overschaduwen. ${ }^{62}$ Blijkbaar heeft dat het zicht ontnomen op het feit dat voordien de meeste staten wat hun uitgaven en personeel betreft hoofdzakelijk gericht waren op militaire activiteiten, en voor een overige (klein) deel op justitic en politic, fiscaliteit en het Hof. $^{63}$

Zo komt een ander pluspunt van deze benadering in beeld: de verbinding die gelegd wordt tussen 'interne' en 'externe' staatsvormende activiteiten. Vooral met het oog op de externe competitie heeft de staatsorganisatie een 'eigen' interesse ontwikkeld voor een aantal interne verhoudingen, instellingen en processen (zoals bijvoorbeeld de ontwikkeling van handel en industrie), die relevant zijn voor de in de externe arena benodigde middelen.

De hier geschetste benadering biedt interessante perspectieven voor toepassing in rechtssociologisch werk. Dit is evenwel niet de plaats om deze mogelijkheden in de breedte te verkennen. Het is hier vooral te doen om het laatstgenoemde punt. Wanneer we deze 'state-centered' benadering transponeren naar het domein van de rechtspraak, komt nadrukkelijk naar voren dat het daarbij niet alleen gaat om een staatsactiviteit die alleen aan 'bottom up' behoeften tegemoet is gekomen, maar ook in 'top down' ambities van waarde is geweest.

61 Terwijl zij toch voor een niet onbelangrijk deel gevormd zijn onder de druk van (en als reactie op) twee totale oorlogen. Cf. Porter (1994) War and the rise of the State, p. 149 e.v.; Klausen (1998) War and welfare, Jetringhoff (2000) Total war and twenticth-century legal change.

62 Mann (1993) The sounces (II), p. 358 e.v.

63 Ibid., p. 378 , 


\section{Staatsvorming en rechtspraak}

Zoals gezegd zal de kwestic van de 'functie' van rechtspraak hier vooral aan de orde komen vanuit een bepaald positioneel perspectief. Een van de vragen is dan, in welke opzichten rechtspraak vanuit de optiek van de Europese (veelal vorstelijke) statenbouwers interessant zou kunnen zijn geweest? Het volgende is uiteraard niet bedoeld als een uitputtende opsomming. Voor het schetsen van de hier bedoelde benadering van gerechten is een kleine staalkaart van enkele evidente belangen voldoende.

In de geest van het voorgaande kan rechtspraak beschouwd worden als een onderdeel in het eerder genoemde protectiearrangement en is dan een aanvaarde methode (procedure) om vast te stellen welke handelingen of aanspraken geldig zijn en eventueel voor ondersteuning met legitieme dwang in aanmerking komen (protectie). Zo bezien heeft rechtspraak een rol bij het rechtvaardigen van concrete toepassing van dwangmacht. Tegelijk biedt het een grond voor optreden tegen onbevoegde dwanguitoefening ('eigenrichting') en daardoor een belangrijk instrument bij het beheersen en monopoliseren van dwangmacht (pacificatie).

Deze 'interne' pacificatie was vanuit de positie van de vorst om verschillende redenen van belang. In de eerste plaats kon door het optreden tegen onruststokers, zoals ambitieuze of tirannieke vazallen die het op de bezittingen van steden, kloosters en elkaar voorzien hadden, worden voorkomen dat 'interne' rivalen een kans kregen voor een greep naar de kroon. Onder dergelijke omstandigheden was het overigens ook riskant ver van huis te zijn voor het aangaan van militaire confrontaties met collega's. Rechtspraak diende langs die weg dus tevens de internationale agenda.

In de tweede plaats waren gerechtelijke procedures alleen al van belang om te laten zien dat de vorst in dat opzicht zijn 'taak' van beschermer naar behoren vervulde. Bovendien was het één van de gelegenheden die kon word aangegrepen om iets te doen aan wat tegenwoordig 'public relations' genoemd wordt. Entourage, kostuums en ceremonieel vertoon beoogden ontzag in te boezemen en dienden ook het publiek van de onaantastbaarheid van het vorstelijk gezag te doordringen.

Voorts kon rechtspraak financieel aantrekkelijk zijn: gerechtskosten werden blijkbaar al vroeg als een interessante bron van inkomsten beschouwd. ${ }^{64}$ Recht-

64 Zo wordt verhaald van de acquisitieve inspanningen van Henry II van Engeland:"... Henry II went far beyond his grandfather. The elder Henry had made his courts efficient, but he had made ne great effort to attract cases from baronial jurisdictions. Henry II did his best to bring all important lawsuits before his own justices. Thus he increased his revenues and at the same time restricted the power of feudal barons. These resules were obtained by great extension of the use of the sworn 
spraak kon direct geld in de koninklijke schatkist brengen zonder tussenkomst van de standen. ${ }^{65}$ Daarnaast waren er ook langs een omweg financiële voordelen te behalen. Uniformering van gewoonterecht via rechtspraak stond onder meer in het teken van het vergemakkelijken van het handelsverkeer, wat weer gunstig zou kunnen zijn voor de opbrengst van heffingen of de mogelijkheid van leningen. ${ }^{6}$

Een ander - vanuit de positie van statenbouwers - utilitair aspect van rechtspraak dat hier vermelding behoeft is in het bijzonder van belang geweest voor het staatsvormingsproces. Het betreft het gebruik van rechterlijke instanties voor het monopoliseren van zeggenschap in een politieke centrum. Van oudsher lag het accent sterk op lokale en gewestelijke autonomie. De landsheren waren zelden zelf de vonniswijzers. Dat was traditioneel het voorrecht van de 'rechtsgenoten' (standsgenoten) der litiganten ter plekke. Aan deze stand van zaken is door de vorsten langdurig getornd met het oogmerk die zeggenschap aan zich te trekken. Daarbij zijn uiteenlopende tactieken gebruikt. ${ }^{67}$ Eén methode was concurrentie: door de introductie van aantrekkelijker (meer rationele, vaak aan het canonieke procesrecht ontleende) procesmethoden kon de 'klandizie' van andere gerechten worden weggevangen in de hoop dat de alternatieven op den duur zouden wegkwijnen. Een andere tactiek bestond uit het introduceren van gerechten voor speciale gevallen, die bij uitsluiting daar behandeld dienden te worden. En ook het instellen van centrale gerechtshoven, die met name in appèl in naam van de vorst recht gingen spreken, paste in deze aanval op de decentrale traditionele jurisdicties, zoals die van de stedelijke gemeenschappen en de canonieke rechtspraak. Dergelijke initiatieven zijn een belangrijk onderdeel geweest in het verwerven van directe zeggenschap door de vorst: centralisatie had de afbraak van de autonome positie der standen als logisch (en bedoeld) gevolg.

Deze reorganisatie opende de mogelijkheid om middels vorstelijke wetgeving het caleidoscopisch geheel van lokaal en regionaal recht te uniformeren of zelfs geheel door geleerd (juristen)recht te vervangen. Dat was interessant met het oog op de vereenvoudiging van de centrale administratie. En tegelijkertijd werd daardoor de decentrale autonomie verzwakt.

Tot de zeventiende eeuw was dit alles niet per se onderdeel van een vooropgezet plan van staatsvorming. Maar dergelijke manoeuvres vormden samen met andere

inquest, or jury." Strayer \& Munro (1959) The Middle Ages, p. 283.

65 Ze behoorden tot de 'gewone' inkomsten naast de inkomsten uit de koninklijke domeinen, i.t.t. de buitengewone, die alleen in zeer specificke omstandigheden (oorlog, losgeld) alleen met instemming van de standen konden worden afgeroepen. Cf. Blockmans (2000) Keizer Karel V, p. 213.

66 Peters (1972) Maatschappelijke verandering, p. 151

67 Padoa-Schioppa (1997) Legislation and justice, p. 356 e.v. 
wel een aanloop in die richting. Ten aanzien van rechtspraak zetten ze een teweging in gang die Van Caenegem typeert als 'de-democratisering' (het verduijnen van rechtsgenoten uit de rechtspraak) en 'verstaatsing' (het inperken van de urisdictie van de standsgerechten).

Deze initiatieven werden uiteraard geïnterpreteerd als inbreuken op tracitionele rechten en konden - als daartoe de mogelijkheid bestond - rekenen op virzet. Eigenlijk kan de rechtspraak worden beschouwd als één van de fronten waraan de staatsvorming is bevochten. Niet alleen stuitte de vorst op - soms zelfs onsverkomelijke - weerstanden bij de introductie van centrale Hoven van Justitie ook op lokaal niveau werd de eigen traditie hardnekkig verdedigd. ${ }^{69}$ Van den tergh schetst de gang van zaken als volgt:

"De uitroeiing van alle vormen van eigenrichting en met name van collectiele acties en volksgerichten in huwelijkskwesties is vele eeuwen lang onderdeel geveest van een beleid dat gericht was op staatsvorming, zoals zich dat in Europa sedrt de late Middeleeuwen heeft ontwikkeld, en niet zelden is het daarbij bloedig vegegaan." $" 0$

reitelijke machitsvertioudingen gaven veelà' dé đóorslág. Waar dé oudé gemeenschappen en standen sterk stonden ten opzichte van het centraal gezag, wisten zij hun greep op de rechtspraak te handhaven. Maar waar ze verzwakten moesten ze langzaam aan plaats maken voor in het geleerde recht geschoolde juristen. Een mogelijke indicatie van de kracht van de weerstand tegen deze aanslagen op de zeggenschap van de standen, vormt het late doordringen van juristen in de rechtspraak. ${ }^{71}$ De praktijk om juristen bij de rechtbank - in verband met vonnissen . advies- en redactiewerk te laten verrichten was soms een tactiek om baas in eigen huis te blijven. ${ }^{72}$ De invloed van de standen heeft zich op sommige plaatsen doen gelden tot aan de Franse Revolutic.

$\mathrm{Bij}$ de geleidelijke opkomst van juristen in het rechtersambt waren de juristen zelf uiteraard belanghebbenden. Een aanzienlijk deel van de juristen behoorde tot de 'middengroepen' en zij hadden te winnen bij het verwerven van dergelijke posities. ${ }^{73}$ Het ging daarbij niet alleen om inkomsten, maar vooral ook om status. Er was via het rechtersambt soms zelfs uitzicht op een adellijke titel (noblesse de robe). Voor de juristen, die uit de middengroepen stamden, was dit de ladder

68 Van Caenegem (1985) Privaatrecht, p. 112 e.v.

69 Monté ver Loren (1982) Hoofallijnen, p.139

70 Van den Bergh (1987) Sociale beheersing, p. 251.

71 Volgens Van den Bergh drongen zij daar later door dan in bestuur en wetgeving. Van den Bergh (1994) Geleend recht, p. 48.

72 lbid., p. 42.

73 Ibid., p. 39 c.v. 
voor sociale stijging. Daarbij waren de rechters van de vorstelijke gerechten wel lange tijd in een afhankelijke positie ten opzichte van dominante monarchen. Tenslotte was de koning de hoogste rechter en waren de rechters van deze rechtscolleges slechts zijn dienaren. In de zestiende en zeventiende eeuw aarzelden vorsten niet om hen onwelgevallige rechterlijke beslissingen te (doen) corrigeren of zonodig halsstarrige rechters te ontslaan. Maar geleidelijk is deze beroepsgroep er in geslaagd een enigszins onafhankelijke positie te verwerven ten opzichte van hun koninklijke werkgevers. ${ }^{74}$ Deze ontwikkeling ging gepaard met het perverse effect dat deze groep koninklijke dienaren in staat was - onder meer middels hun beslissingen - absolutistische ambities van hun vorsten ernstig te frustreren.

Het zijn uiteindelijk de verlichte absolutisten, de Franse revolutionairen en het Napoleontisch regime geweest, die het proces van centralisering en monopolisering van rechtspraak op het Europese continent hebben voltooid. In de meeste westerse nationale staten gold sindsdien nationaal recht en eenheid van rechtspraak.

Het bovenstaande bedoelt uiteraard niet in de eerste plaats de historie van rechtspraak in het proces van staatsvorming in Europa te schetsen, maar dient slechts ter ondersteuning van enkele elementen van een ander beeld van rechtspraak dan in de rechtssociologie gewoonlijk is gehanteerd. Een eerste element daarin is dat rechtspraak - in de context van het staatsvormingsproces - ook voor statenbouwers zelf op verschillende manieren voor het realiseren van hun politieke ('interne' en 'externe') ambities van groot belang is geweest. ${ }^{75}$ Padoa-Schioppa concludeert:

"... it was to a large extent $[. .$.$] through a growing control over the instrument of$ justice that the state attained its primacy, using the procedures of specialization, competition, monopoly and hierarchy for its own ends. ${ }^{.76}$

De vorstelijke 'zorg' voor rechtspraak kon wel tevens het belang van verschillende maatschappelijk groeperingen dienen, maar dat was zeker niet het enige. 'Society-centered' benaderingen van rechtspraak reduceren te zeer de diversiteit van positionele belangen (en dus ook krachten) rond rechtspraak.

Een tweede element hangt met het vorige samen. Het is de stelling dat de ontwikkeling van rechterlijke instanties het resultaat is geweest van wisselende

74 In Engeland werd onafzetbaarheid uiteindelijk in 1701 wettelijk vastgelegd; Cf. Van Caenegem (1991) The common law seen from the European Continent, p.170. In Frankrijk was onafzetbaarheid het feitelijk gevolg van de verkoop van rechterlijke posities; Dawson (1968) The oracles of the law, p. 350 e.v.

75 Waarschijnlijk belangrijker dan blijkt uit het merendeel van de historisch-sociologische literatuur, waaraan hier gerefereerd wordt.

76 Padoa-Schioppa (1997) Legislation and justice, p. 349. 
krachtsverhoudingen binnen een meerzijdig krachtenveld. De vorstelijke initiatieven ter centralisatie en monopolisering van rechtspraak in Europa waren vooral ook (onderdeel van) een strijd tegen de zeggenschap van - en dus voor de heerschappij over - andere maatschappelijke geledingen, de standen. In de uiteenlopende histories van de organisatie en werkwijze van rechterlijke instanties in de diverse landen van Europa is het verloop van dit conflict af te lezen. Ook de opmars van de universitair geschoolde juristen als rechters heeft bijgedragen aan het beëindigen van decentrale zeggenschap op het vlak van rechtspraak. Zij hebben een rol gespeeld bij de strijd tegen het standenelement in rechtspraak. Daarmee werd overigens een nieuwe groepering geïntroduceerd in het historische krachtenspel rond rechtspraak, voorzien van weer een ander scala van positionele belangen, ambities en niet te vergeten: binnen de eigen professionele gelederen ontwikkelde doctrines. Met name de door het structuur-functionalisme geïnspireerde benaderingen van rechtspraak hebben de tendentie het element van confrontatic en manipulatie rond de instellingen, dat hierboven in beeld is gebracht, te verwaarlozen.

Een derde element geeft aan, dar in dit krachtenveld niet alloen 'binnenlandse' maar ook 'buitenlandse' krachten zich (direct of indirect) hebben kunnen doen gelden. Verandering van rechtsinstellingen is vaak het resultaat geweest van selectieve imitatie, het overnemen van instellingen van succesvolle koninkrijken en nationale staten. Maar buitenlandse invloeden deden zich soms ook direct gelden, bijvoorbeeld na een machtswisseling door een (verloren) oorlog.

Met het ontstaan van de geconsolideerde nationale eenheidsstaten zijn deze elementen niet verdwenen. Zowel in autoritaire als in democratische politieke constellaties is de plaats van de rechter voorwerp van 'druk en trek' geweest. Naast nationale politiek-bestuurlijke ontwikkelingen doen ook internationale ontwikkelingen nog steeds invloed op de plaats van de rechter gelden. Sinds en gedeeltelijk ten gevolge van de Wereldoorlogen van de vorige eeuw is een proces van internationalisering in gang gezet. Nationale staten hebben soevereine bevoegdheden overgedragen aan supranationale organen. Dit proces heeft de positie van de rechterlijk macht doorgaans versterkt, althans ten opzichte van de overige staatsmachten. ${ }^{78}$ Parallel aan deze ontwikkeling is ook de economische internati-

77 Zie bijvoorbeeld over rechtspraak en autoritaire regimes: Tate (1992) Courts and crisis regimes. Ook in democratische staten bestaan er fricties tussen bijvoorbeeld bestuur en rechrsprak; de klacht van enkele Nederlandse bestuurders over de opkomst van de rechterstaat is een recente indicatie van een oud spanningsveld. Cf. Pieterman (1990) De plaass wan de rechter in Nederland 1813-1920; Verhey (1997) Reshesbescherming in Nederland.

78 Cf. Ten Napel (1994) De veramerikanisering uan de Nederlandse rechter, Tate of Vallinder (1997) The global expansion of judicial power. 
onalisering (mondialisering) weer op gang gekomen. $\mathrm{Na}$ een stormachtige groei aan het eind van de negentiende eeuw was deze ontwikkeling door het uitbreken van de Eerste Wereldoorlog abrupt afgebroken. Een interessante vraag is welke invloed deze economische internationalisering voor vorm en taaklast van de burgerlijke rechtspraak zal hebben.

De hier geschetste benadering staat ook zelf niet los van de zojuist genoemde ontwikkelingen. Op dit verband is in de context van een ander onderwerp ook al gewezen. In een bespreking van een boek van Halliday en Karpik over advocaten en de politiek van de nationale staat, omschrijft Scheingold de wending naar de 'grote' politiek die in dit boek wordt gemaakt als een "creature of its time"; evenzeer overigens - merken zij op - als voorgaande benaderingen dat zijn geweest. Er wordt zo een verband gelegd met debarten over recente ontwikkelingen, zoals onder meer de terugtred van de interventiestaat en mondialisering. ${ }^{79}$ Mutatis mutandis kan over de hierboven voorgestelde benadering hetzelfde gezegd worden.

\section{Rechtspraak en 'alternatieven'}

De zogenaamde 'alternatieve', buitengerechtelijke instanties voor geschillenbehandeling (alternative dispute resolution of ADR) vormen al geruime tijd een bekend thema in de rechtssociologische literatuur en ook in de Nederlandse juridische literatuur staat het de laatste jaren volop in de belangstelling. ${ }^{80}$ In welk opzicht zou de perspectivistische benadering die hier is beproefd dit thema in een ander licht plaatsen dan de gevestigde invalhoeken?

Buitengerechtelijke geschilinstanties of behandelingsmethoden worden in functionalistische benaderingen meestal gekenschetst als 'alternatieven' ten opzichte van statelijke gerechten, omdat ze dezelfde functie wordt toegeschreven, zoals sociale integratie of sociale controle. Een bekende en veel aangehaalde opsomming van de hand van Galanter vormt een voorbeeld van deze invalshoek. ${ }^{81}$ Tussen berechting en berusting schetste hij een heel landschap van 'dispute-settlement systems' en daarnaast nog vormen van (eenzijdige) zelfhulp. Sommige van deze systemen typeert hij als duidelijk geënt op het 'officiële systeem' wat betreft de toegepaste normen en sancties ('appended systems'). Andere systemen ('systems of private justice') hanteren andere normen en sancties, die in meerdere of mindere mate een georganiseerd karakter hebben. Volgens Galanter

79 Scheingold (1999) Taking Weber seriously, p. 1067.

80 Voor een overzicht: Hertogh en Kleiboer (1996) Anders dan rechtspraak.

81 Galanter (1974) Why the haves, p. 124 e.v. 
is het van het karakter van de relatie (de mate van 'density', een combinatie van duurzaamheid en veelzijdigheid) afhankelijk, op welk systeem eventueel een beroep zal worden gedaan. Met name de incidentele en kortstondige relaties (een context waarin moeilijk gemeenschappelijke normen en waarden kunnen worden ontwikkeld) zullen volgens deze zienswijze bij de officiële en de aangehangen systemen terechtkomen. Aan de andere kant van het continuüm worden de duurzame en veelzijdige relaties verwacht, want

"they create the possibility of effective sanctions and we would expect participants in such relationships to share a value consensus which provided standards for conduct and legitimized such sanctions in case of deviance." ti

Hier klinkt iets door van het functionalisme à la Schwartz: als de sociale dichtheid van relaties afneemt wordt de werking van informele sociale controle minder effectief, en dat zal formele sociale controle noodzakelijk maken. ${ }^{83}$ In wezen zijn de verschillende instellingen functionele equivalenten, want ze dienen dezelfde functic.

De opstelling van de hervormingsgezinden tegenover de "informal justice'-beweging is enigszins ambivalent. Enerzijds bieden alternatieve fora een gelegenheid om belangen te representeren die anders moeilijk aan bod komen. Anderzijds is de vrees geuit dat het afschuiven van geschillen naar informele fora zal betekenen dat de macht van de staat ('capitalist state') eerder zou toenemen dan afnemen. ${ }^{84}$ Immers de mogelijkheid om politieke en bestuurlijke besluitvorming via het gerecht structureel te beïnvloeden zou dan komen te vervallen. Emancipatoire bewegingen zou zo een belangrijk instrument uit handen geslagen worden.

Vanuit de perspectivistische benadering is er niet één antwoord te geven op de vraag waar rechterlijke instanties of 'alternatieven' toe dienen. Dat hangt af van de positie van waaruit ze worden bezien. Waarin onderscheidt rechtspraak zich van andere modaliteiten van 'geschilbehandeling' vanuit het standpunt van de aanbieders? Zuiver vanuit de institutionele logica van staatsvorming gedacht heeft rechtspraak een belangrijke taak bij het beheersen van interne geweldstoepassing. Voor zover de overheid niet eigener beweging - middels het bestuursapparaat - actief beschermend tegen schending van rechten optreedt, kan voor het overige bescherming worden ingeroepen (en zonodig bijstand van de 'sterke arm' voor rechtsherstel als daarvoor een acceptabele grond wordt aangewezen). Rechterlijke beslissingen openen de mogelijkheid tot de toepassing van rechtmatige dwang, uitgeoefend door bevoegde instanties. In die zin is rechterlijke tussenkomst niet

82 Ibid., p. 131/132.

83 Cf. de klassicke tekst van Schwartz (1964) Social contral.

84 Een vrocg commentaar is van Abel (1981) The contradictions of informal justice. 
per se vrij van (dreigen met) geweld. ${ }^{85}$ Rechters behoren tot de poortwachters van statelijke dwang. Alle dwanguitoefening door onbevoegden is op grond van (hiervoor reeds genoemde) overwegingen van staatsraison uit den boze. Het 'alternatief dat vanuit deze optiek vooral belangrijk is, wordt betiteld als 'eigenrichting'. Dit is de dwangtoepassing die moet worden beteugeld of liever nog voorkomen. Het lijkt moeilijk meer voorstelbaar dat dergelijke alternatieven ooit een gevestigde status hadden. Vanuit dit perspectief is het feit dat mensen hun geschillen eenzijdig, samen of met behulp van een derde op allerlei andere manieren (arbitrage, bemiddeling, overleg, exit of wat dies meer zij) proberen op te lossen niet problematisch, want het zijn allemaal vreedzame methoden. Alhoewel een ruim gebruik van deze methoden gevolgen kan hebben voor de taaklast van de rechter, zijn ze op het kritieke punt (afdwingbaarheid) toch geen equivalente en dus concurrerende methoden. ${ }^{86}$ Bovendien komen ze meestal niet ten laste van de schatkist.

Maar dit aspect van rechtspraak is niet alleen vanuit het politiek-bestuurlijke perspectief van belang, maar in beginsel ook vanuit het perspectief van de andere kant van het beschermingsarrangement, dat van de 'cliënten'. Wie meent dat hem of 'naan ornectn is aangedaan 'kan proberen z̈jjn of ' haar vermeende rechten te beschermen met behulp van staatsdwang of daar in ieder geval mee dreigen. Het element van dreiging klinkt dan ook door in de manier waarop doorgaans over het inschakelen van een juridisch adviseur of over een (voorgenomen) beroep op de rechter wordt gesproken: er worden 'juridische stappen' of overwogen of gedaan. De medewerking van de andere partij is daarvoor niet per se nodig.

Daarmee is overigens niet gezegd dat daadwerkelijke toepassing van dwang bij rechtshandhaving een gezochte oplossing is. Vanuit politiek-bestuurlijk perspectief is dwang een duur en riskant instrument, en dat kan een reden zijn om het bij voorkeur spaarzaam te hanteren. Dat kan tot gevolg hebben dat van het daadwerkelijk effectueren van een rechterlijke uitspraak soms weinig terecht komt. ${ }^{87}$ En ook aan de kant van de rechtzoekenden is een afdwingbare rechterlijke uitspraak veelal niet wat beoogd wordt. Galanter heeft procederen eens getypeerd als 'litigotiation':

85 Dit is in afwijking van een categorisering van methoden van conflictbeslechting van Schuyt. Hij heeft een scherp onderscheid gemaakt tussen 'geweld' en de meeste andere vormen van geschilbeslechting, waaronder rechterlijke tussenkomst (die blijkbaar niet aan dwang of geweld is gerelateerd). Schuyt (1983) Recht en samenleving, p. 53 c.v. Het overzicht heeft hem onder meer tot de conclusie gevoerd dat: "[het recht] dient om de gewelddadige vormen van conflictbeslechting te transformeren in geweldloze vormen van conflictbeslechting (rechterlijke tussenkomst en bestuurlijk-politieke oplossing)". Ibid., p. 65.

86 Vanuit het perspectief van de rechterlijke macht kan een ontwikkeling in deze richting mogelijk weer wel als concurrentie worden gezien.

87 Van Koppen en Malsch (1997) De waarde van civiele vonnissen. 
"that is, the strategic persuit of a settlement though mobilizing the court process. Hij heeft er op gewezen dat veel procedures voor de uitspraak worden beëindigd. In feite worden de onderhandelingen in een andere context en op andere termen voortgezet. Dat is waar advocaten en rechters vaak op aansturen. Maar ook partijen zelf zijn daar waarschijnlijk vaak op uit. Een belangrijke reden daarvoor zou kunnen zijn dat vrijwillige relaties (zoals affectieve relaties en ruilrelaties) geen dwang verdragen. Als er dwang aan te pas moet komen betekent het eigenlijk dat de relatie beëindigd is. Wil men de relatie behouden, dan is het belangrijk er 'samen uit te komen'. Daarin schuilt waarschijnlijk voor een belangrijk deel de aantrekkelijkheid van methoden van geschilbehandeling die de instemming van beide betrokkenen vereist.

In het onderzoek waarvan hier verslag zal worden gedaan, komen potentiële gebruikers van gerechtelijke en buitengerechtelijke instanties aan het woord. Om het open (cliënten)perspectief en ook het punt van Galanter tot uitdrukking te brengen zal hier de opzettelijk wat vage terminologie gehanteerd worden van 'juridische stappen', voor alle andere door juridische deskundigen geïnformeerde of begeleide actie, inclusief 'gerechtelijke stappen' bij de overheidsrechter..

\section{Besluit}

De hiervoor geschetste benadering postuleert dat het bestaan van bepaalde gerechtelijke instanties, evenmin als een bepaald volume aan procedures, noodzakelijk alleen een bepaalde maatschappelijke 'behoefte' of neiging ('litigiousness') aan de vraagzijde tot uitdrukking brengen. Voor een goed begrip van deze faciliteiten en het beroep dat erop is gedaan, kan de geschiedenis van de vorming van het 'aanbod' van deze gerechtelijke faciliteiten veel verklaren.

Wat is dan het belang van het onderzoeken van het omgaan met klachten en conflicten aan de vraagzijde? Het antwoord moet uiteraard luiden dat de manoeuvres van de statenbouwers en hun personeel zijn niet allesbepalend zijn geweest. Het is bijvoorbeeld in het voorgaande gebleken dat beslissingen aan de vraagzijde, waardoor eb en vloed van de rechterlijke taaklast gestalte krijgen, medebepalend kunnen zijn voor het voortbestaan en de inrichting van gerechtelijke procedures. Een rechtsgang die minder aantrekkelijk wordt bevonden dan een 'concurrerende' procedure kan op die manier een zachte dood sterven. Het ligt in ieder geval niet voor de hand enige wisselwerking op voorhand uit te sluiten. Het is ook voor-

88 Galanter (1984) Worlds of deals, p. 268; cf. Bruinsma (1995) Kadi-rechtspraak in postmodern Nederland, p. 8 
stelbaar dat sociale ontwikkelingen die geheel los staan van de justitiële sfeer toch van invloed zijn op het bestaan, vorm en taaklast van gerechtelijke faciliteiten. De introductie van de hiervoor omschreven 'reflexieve methoden' en ook het mogelijk verdwijnen van duurzame relaties in het zakenleven zijn mogelijk voorbeelden van dergelijke autonome sociale ontwikkelingen die de taaklast van de rechter en daarmee de vorming van gerechtelijke instellingen kunnen beïnvloeden, en ook daarom nader onderzoek waard.

Maar het onderzock van de vraagzijde leent zich soms slecht voor het verhelderen van achtergronden van een bestaand aanbod. In dit onderzoek zullen we nog stuiten op procedures met kenmerken die evident niet op de wensen van de vraagzijde zijn geënt. Om dergelijke ogenschijnlijke discrepanties te verklaren is onderzoek noodzakelijk dat zich specifiek op de wording van de procedures richt. Onderzoek van de vraagzijde blijkt daarvoor ontoereikend. 



\section{HOOFDSTUK 3}

\section{Vraagstelling en onderzoeksopzet}

Het is doorgaans betrekkelijk uitzonderlijk dat geschillen uitlopen op een gerechtelijke procedure. De civiele rechter ziet alleen het topje van de ijsberg aan geschillen. Meestal geeft men er de voorkeur aan de kwestie anders op te lossen. Het vermijden van gerechtelijke procedures is normaal, zou men kunnen zeggen.' Soms is het mogelijk om van eigen ervaringen te leren, zodat de afwikkeling van geschillen in gewenste banen wordt geleid, of dat maatregelen kunnen worden getroffen waardoor het ontstaan van conflictstof wordt voorkomen.

Deze methodische praktijken zijn niet voor iedereen weggelegd. Een particulier kan proberen het doen van juridische stappen te vermijden, maar hij of zij zal doorgaans niet in staat zijn in dat opzicht een methodische aanpak te ontwikkelen. Daarvoor doen zich in een mensenleven meestal te weinig gelijksoortige gebeurtenissen voor die daartoe aanleiding kunnen geven. Dergelijke strategieën liggen soms wel in het vermogen van de routiniers (Galanters 'repeat players'), doorgaans bureaucratische organisaties zoals bijvoorbeeld bedrijven. Uit eerder onderzoek bleek dat bepaalde bedrijven, die grote aantallen particuliere klanten bedienen, methoden hanteren om het aantal wanbetalers onder controle te krijgen. ${ }^{2}$ De vraag die in dit onderzoek centraal staat kan kort worden geformuleerd: worden dergelijke methodische praktijken met betrekking tot het afhandelen en voorkomen van klachten en geschillen ook gehanteerd in de relaties tussen bedrijven onderling en in welke omstandigheden zien bedrijven een reden om tot dergelijke werkwijzen over te gaan?

1 Blankenburg en Verwoerd (1987) Vermijden en benutten van civielrechtelijke procedures, p. 22: "het aantal rechtszaken [zegt] meer over de geneigdheid van mensen om de rechtspraak als conflictoplossende instantie te vermijden dan over hun geneigdheid om deze op te zoeken..."

2 Jettinghoff (1991) Daderprofielen in het privaatrecht. 
In dit hoofdstuk zal eerst de vraagstelling nader worden uitgewerkt. In het tweede gedeelte van dit hoofdstuk zal de opzet van het onderzoek uiteen worden gezet.

\section{Vraagstelling}

\section{Beheersing van klachten en geschillen}

De werkwijzen waar het in dit onderzoek om gaat zijn door Giddens bestempeld als een kenmerkend verschil van moderne ten opzichte van traditionele maatschappijen. Hij heeft deze kenmerkende processen samenvattend betiteld als 'reflexiviteit' en hij heeft daarmee vooral bedoeld de voortdurende wisselwerking tussen sociale praktijken en kennis over die praktijken. ${ }^{3}$ Reflexiviteit houdt volgens de lezing van Giddens in, dat sociale praktijken voortdurend in kaart worden gebracht en dat die kennis vervolgens een rol gaat spelen in diezelfde sociale praktijken, die daardoor van karakter kunnen veranderen. Dat laatste zal meestal het gevolg zijn van het feit dat de deelnemers aan die praktijken op grond van de vergaarde kennis hun (samen)handelen heroriënteren.

Als voorbeeld van deze reflexiviteit wijst hij op de afstemming en bijsturing van staatsinterventies op grond van stelselmatig ingewonnen statistische gegevens over de desbetreffende beleidsvelden. De daarbij gehanteerde categorieën (niet zelden ontleend aan in regelgeving aangebrachte indelingen) zijn inderdaad een belangrijk onderdeel geworden van de woordenschat van politieke en ambtelijke experts, die zich beroepshalve met beleidsvorming en -uitvoering bezighouden. Dergelijke kennis maakt het mogelijk dat men zich bij het ontwerpen of herzien van beleid een beeld kan vormen van hoe het er voor staat met bijvoorbeeld de vergrijzing, de nieuwe economie, de werkgelegenheid, de opvang van asielzoekers en dergelijke. Deze reflexieve 'feedback loop' van waarnemen naar handelen is volgens Giddens dan ook een onontbeerlijke voorwaarde geworden van de administratieve macht van de nationale staat. ${ }^{4}$

Sommige van deze statistische categorieën worden overigens ook buiten de kring van beleidsmakers gemeengoed, bijvoorbeeld doordat er in de media veel

3 Giddens (1990) The consequences, p. 36 e.v; om niet weer een nieuw begrip te introduceren, is de benaming van Giddens ("reflexivity") hier gehandhaafd, ofschoon het begrip in de literatuur niet altijd dezelfde betekenis heeft: of. Nelken (1994) Refloxive criminology?. p. 9 en Van der Veen (2000) De urraorgingotaat in de laat-moderniteit, p. 65.

4 Giddens (1985) The nation-state and violence, p. 180. 
aandacht aan is besteed, of omdat men zich zelf (met vreugde of verdriet) tot zo'n categorie gerekend ziet. Dergelijke categorieèn en de bijbehorende informatie kan zo onderdeel gaan uitmaken van het interpretatiekader waarmee moderne mensen hun alledaagse ervaringswereld begrijpen.' Soms ook wordt een dergelijke categorie de noemer voor een belangenorganisatie die voor haar werk zelf informatie verzamelt over de achterban en nieuwe categoriežn aandraagt. De reflectieve 'feedback loop' kan zich dus op verschillende niveaus voltrekken.

Reflexiviteit is volgens Giddens niet alleen typerend voor overheidsorganisaties en hun ring van pressiegroepen, maar ook voor particuliere organisaties zoals ondernemingen. De dubbele boekhouding is een klassiek voorbeeld van een reflexieve techniek. ${ }^{6}$ Maar daarbij is het - onder meer onder invloed van technologische innovaties - niet gebleven. De digitale informatietechnologie heeft bijvoorbeeld nieuwe mogelijkheden geschapen voor concerns die een beeld wensen te verkrijgen van hun omvangrijke en in hoofdzaak anonieme bestand van afnemers. Hiervoor zijn (in het eerste hoofdstuk) al voorbeelden aangehaald van reflexieve technieken van banken, supermarktketens en autofabrieken. Ze komen er op neer dat men, middels de verzameling van gegevens over individuele klanten, tracht 'goede' klanten aan zich te binden. Daartoe is bijvoorbeeld speciale sofware ontwikkeld die, zoals het in het jargon heet, 'Customer Relationship Management' (CRM) mogelijk makkt. ${ }^{7}$ Op die manier denkt men beter te kunnen inspelen op de wensen van de klant. Dat betekent dat van de verzamelde gegevens gebruikt wordt gemaakt om de activiteiten van het bedrijf beter te richten op de verlangens van de klanten:

"... informatie wordt opgeslagen in een database en geanalyseerd. Op die manier kan het bedrijf per klant een boekhouding maken en activiteiten toerekenen aan individuele klanten. Door alle klanten 'over elkaar heen te leggen' vallen bovendien klantclusters te onderscheiden waarbij het profiel van de beste maar ook de slechtste klanten naar voren komt. Die worden als zodanig gelabeld. Menig bedrijf waar CRM is geïmplementeerd, onderscheidt 'gouden', 'zilveren' en 'bronzen' klanten. Vervolgens worden daar 'business rules' op los gelaten, die bepalen hoe per klanttype het contact wordt onderhouden."

Organisatieprocessen worden zo permanent aangepast om adequaat te kunnen reageren op de informatie over de klantenwensen die van de 'front office' (de benaming voor de 'street-level bureaucrats' van het bedrijfsleven) afkomstig is. De permanente opvolging van informatieverzameling, evaluatic en bijsturing kan zo

Idem (1990) The consequences, p. 43.

6 Idem (1984) The constitution of society, p.205.

7 Ontleend aan Het Financiecle Dagblad, 16-8-2000.

8 Het Financiecle Dagblad, t.a.p. 
resulteren in een zichzelf voedend veranderingsproces, dat - in een ander licht bezien - kenmerkend is voor het 'staccato karakter van onze cultuur'?

Giddens kenschetst reflexiviteit als een proces waarin sociale praktijken doordesemd raken met wetenschappelijke begrippen, theorieën en onderzoeksgegevens. Alle sociale wetenschappen, maar met name ook de sociologie, zijn daarin volgens hem betrokken. ${ }^{10}$ Voor de reflexieve technieken waar het in het volgende om gaat past enige relativering wat betreft het 'wetenschappelijke' karakter ervan. Zoals uit het bovenstaande voorbeeld al valt op te maken gaat het vaak niet zozeer om 'zuivere wetenschap', maar meer om overwegend op de praktijk toegesneden technieken.

Reflexieve technieken zijn in het verband van dit onderzoek van belang, omdat zij - zoals al is aangegeven - soms ook door bedrijven worden ingezet bij het hanteren van regelmatig rijzende problemen met particuliere klanten, waarbij het doen van juridische stappen regelmatig een optie is. Deze methode komt in hoofdzaak neet op enerzijds het efficiënt routiniseren van ontstane vorderingen en anderzijds het systematisch selecteren van 'goede' klanten. Dit laatste werkt kort gezegd als volgt: over alle klanten wordt informatie verzameld, bij voorkeur op grond van eigen waarneming, soms ook aangevuld met informatie uit externe bronnen. Deze gegevens maken het mogelijk om op basis van 'credit rating' de risicovolle klanten met meer voorzorg te behandelen dan de minder risicovolle. En verder worden op basis van 'postcodeprofilering' nieuwe klanten geworven, waarvan - statistisch gesproken - kan worden verwacht dat ze goede klanten zullen zijn, ook wat betreft de betalingsbetrouwbaarheid.

In het hierna gerapporteerde onderzoek is gezocht naar het gebruik en de belangrijkste kenmerken van werkwijzen waarmee ontstane klachten worden afgehandeld en de methoden waarmee getracht wordt klachten en conflicten te voorkomen: dit keer niet in relaties tussen bedrijven en consumenten maar in de relaties tussen bedrijven onderling. Daarbij is voorts de vraag in hoeverre het daarbij gaat om reflexieve methoden, dat wil zeggen preventieve praktijken, die stelselmatig geïnformeerd worden door de ervaringen die met het behandelen van

9 Zijderveld (1991) Stacoato cultuar, p. 57 e.v. ; hierbij doet zich de paradox voor, dat gezocht wordt naar duidelijkheid, terwijl die tegelijkertijd steeds meer (geheel in lijn met de these van Zijderveld) aan het verdwijnen is; de reden waarom bijvoorbeeld het inspelen van bedrijven op de wensen van de klant noodzakelijk wordt geacht is veelzeggend: de fragmentatie van de traditioneke consumptiepatronen. Hoogleraar Electronic Marketing Molenaar geeft de volgende verklaring "Homogene groepen worden steeds kleiner. Het werd steeds lastiger clusters te maken op basis van traditionele sociodemografische kenmerken als leefrijd, sekse, opleiding en geslacht." Het Financiecle Dagblad, t.a.p.

10 Giddens (1990) The consequences, p. 40-45. Volgens Snel geeft Giddens de wetenschap te veel eer; of. Snel (1996) Voorbij 'enginerring' en 'enlightenment'; p. 113 e.v. 
klachten en conflicten worden opgedaan. Tenslotte zal gekeken worden naar de effectiviteit van deze praktijken. Kan gezegd worden dat het gebruik van deze praktijken de verklaring is voor het zelden voorkomen van klachten en conflicten in transacties tussen bedrijven of zijn daarvoor er nog andere omstandigheden van betekenis?

Wat betreft de omstandigheden waarin aanleiding wordt gezien deze methoden te gebruiken biedt een tweetal rechtssociologische thema's interessante suggesties. Rond deze aanknopingspunten is het onderzoek in hoofdzaak georganiseerd.

\section{Relaties tussen bedrijven}

De eigen dynamiek van economische relaties vormde het centrale element in de verklaring van Galanter en Rogers voor een gesignaleerde toename van het aantal procedures in de jaren ' $80 .{ }^{\text {"I }}$ Hun verklaring verwees naar het mogelijke verdwijnen van de door Macaulay in 1963 geschetste 'longterm continuous relationships', die in het zakenleven van de jaren ' 50 en ' 60 prominent aanwezig waren gebleken. ${ }^{12}$ Deze ontwikkeling zou al sinds het begin van de jaren ' 70 gaande zijn geweest. $^{13}$

Het onderzoek van Macaulay uit 1963 was erop gericht de veronderstellingen over de maatschappelijke rol van het contractenrecht, die hij in juridische handboeken aantrof, te confronteren met empirische gegevens over contractuele relaties in het bedrijfsleven. De handboeken veronderstelden volgens Macaulay (en overeenkomstig de institutioneel economen), dat in een markteconomie (1) marktpartijen die met elkaar een transactie tot stand willen brengen hun verhouding tot in de details plannen in het licht van rechtsgeldigheid en de kans op niet-nakoming (2) het contractenrecht daarbij van groot gewicht is, omdat het de constructie van rechtsgeldige en afdwingbare contracten vergemakkelijkt (3) de mogelijkheid van een civiele procedure het belangrijkste middel is om wanprestatie tegen te gaan en om geschillen op te lossen. De gegevens van zijn onderzoek schilderden een geheel ander beeld van contractuele praktijken in het bedrijfsleven. Contractuele planning en het contractenrecht bleken bij het aangaan van veel ruiltransacties en ook voor het bijstellen van de verhouding en het oplossen van geschillen van marginaal belang. In her bedrijfsleven werden vaak geen gedetailleerde afspraken gemaakt, werd weinig belang gehecht aan door juristen opge-

11 Galanter en Rogers (1991) The transformation of American business disputing?

12 Macaulay (1963) Non-contractual relations.

13 Cf. ook: Macaulay (1985) An empirical view of contract. 
stelde contracten en bleek men weinig op te hebben met een juridische benadering van zakelijke relaties. Voorts bleek dat het tussentijds bijstellen van de verhouding en het afwikkelen van geschillen vaak gebeurde in onderhandeling, zonder verwijzing naar de gemaakte afspraken, met het inroepen van rechten of een beroep op de rechter. Procedures bleken zelden voor te komen. Deze gang van zaken verklaarde Macaulay met er op te wijzen dat 'contract' in het zakenleven van toen niet nodig was en bovendien ongewenste gevolgen kon hebben. Het was niet nodig, omdat er onder meer verschillende effectieve niet-juridische saneties konden worden gehanteerd, waaronder vooral de angst toekomstige orders van de klant in kwestie of van andere klanten mis te lopen. Procederen is in dat opzicht ook gevaarlijk:

"A breach of contract law suit may settle a particular dispute, but such an action often results in a 'divorce' ending the 'marriage' between the two businesses, since a contract action is likely to carry charges with at least some overtones of bad faith. " Het onderzoek van Macaulay heeft veel onderzoekers tot vervolgonderzoek geinspireerd en de kern van de these is daarbij veelal bevestigd. ${ }^{15}$ Er zijn argumenten aan ontleend tegen een individualistische conceptie van economisch handelen en van het contract als een incidentele transactie. ${ }^{16}$ In het economisch verkeer moesten "duurzame relaties" als een normaal verschijnsel worden gezien. ${ }^{17}$ En voor dergelijke relaties is het juridiseren van problemen niet nodig en zelfs gevaarlijk. Galanter en Rogers hebben, zoals in het eerste hoofdstuk al is aangegeven, naar aanleiding van onderzoek waaruit bleek dat het aantal procedures in het bedrijfsleven een stijgende lijn vertoonde, gesuggereerd dat duurzame relaties in het bedrijfsleven ondermijnd werden door de internationalisering van het economisch verkeer en dat frequenter procederen daarvan waarschijnlijk het gevolg was. ${ }^{18}$

Deze veronderstellingen over de richting van de ontwikkeling van het aantal procedures in het bedrijfsleven zijn evenwel later, in het statistisch onderzoek van Dunworth en Rogers, niet bevestigd. ${ }^{19}$ Met betrekking tot de ontwikkeling van het beroep op de burgerlijke rechter in relatie tot economische groei in Nederland is Bloembergen tot min of meer overeenkomstige conclusies gekomen. ${ }^{20} \mathrm{Bij}$ het

14 Macaulay (1963) Non-contractual relations, p. 64

15 Zie voor een literatuuroverziche: Griffiths (red.)(1996) De sociale werking van bet recht, p.88 e.v. Tocgevoegd kunnen worden: Deakin en Michie (1997) Contracts, cooperation and competition en een reeks artikelen in Cambridge Journal of Economics (1997) p. 121 e.v.

16 Cf. Swedberg en Granovetter (eds.) (1992) The sociology of economic life, p. 21; Griffiths, t.a.p. 17 Vooruitopend op later sociologisch onderzoek, dat de "markt-als-netwerk" in beeld bracht: $d$. Swedberg (1994) Markess as social structures, p. 267 e.v.

18 Galanter en Rogers (1991) The thansformation.

19 Dunworth en Rogers (1996) Corponations in court.

20 Bloembengen (1995) Ubi iudicia deficiunt incipit bellum. 
speculeren over een mogelijke verklaring van deze trend noemt hij ook processen die hiervoor in verband zijn gebracht met reflexiviteit. Bureaucratische (publieke, semi-publieke en private) organisaties zijn tegenwoordig dominant in het maatschappelijk leven aanwezig. Sociale relaties spelen zich meer dan vroeger af tussen bureaucratische organisaties en individuen en tussen deze organisaties onderling. Deze organisaties hebben volgens Bloembergen een voorkeur voor 'rationeel en efficiënt' handelen. Dat laat zich moeilijk met procederen verenigen:

"Het gaat wel om repeat players, maar cigenlijk spelen ze liever helemaal niet en geven ze er verre de voorkeur [aan ] conflicten te voorkomen en als ze er toch zijn. deze buiten proces te regelen." 21

Het zou kunnen zijn dat de introductie van reflexieve methoden in het verlengde ligt van deze voorkeur.

Het is de bedoeling in dit onderzoek materiaal aan te dragen waarmee de stand van zaken wat betreft de relaties tussen bedrijven wat beter kan worden geduid. $\mathrm{Er}$ dienen zich verschillende mogelijkheden aan. Allereerst is het mogelijk dat de duurzame relaties van Macaulay, ondanks de internationalisering van de economie en alle gevolgen van dien, nog steeds springlevend zijn, zoals Macaulay zelf onlangs ook concludeerde. ${ }^{22}$ Preventieve reflexieve methoden zijn in dat geval niet dringend noodzakelijk en zullen dus niet veel gebruikt worden. Voorts kan het zijn dat Galanter en Rogers toch gelijk hebben, maar dat de toegenomen kansen op procedures zijn ondervangen door het inschakelen van preventieve praktijken. Ten slotte is er nog de mogelijkheid, dat het effect van de duurzame relaties tussen bedrijven gesteund wordt door de preventieve praktijken. De mogelijkheid van een dergelijke synergie werd geillustreerd in de consumentensector. Daar bleken deze twee werkwijzen een doel-middel relatie te hebben: bedrijven trachtten 'goede' klanten met behulp van reflexieve technieken te selecteren en ze daarna aan zich te binden, mede met het oog op het beperken van betalingsproblemen.

Het is uiteraard slechts in zeer beperkte mate mogelijk met een momentopname van zich voornamelijk op microniveau afspelende processen en praktijken, de ontwikkeling van een zo heterogeen geheel als het domein dat de burgerlijke rechtspraak bestrijkt (of zelfs maar een deel daarvan), te begrijpen. Dat leert een historische analyse van Kagan van het tegen de economische groei in teruglopen van het aantal gerechtelijke procedures terzake van invordering van schulden in de Verenigde Staten. ${ }^{23}$ Zijn verklaring van die ontwikkeling doet vooral een beroep op institutionele veranderingen, al komen de praktijken op microniveau wel

21 Ibid., p. 34.

22 Macaulay (1996) Organic transactions, p. 117

23 Kagan (1984) The routinization of debt collection, p. 323 e.v. 
aan de orde. Eén van ontwikkelingen die hij ter verklaring aanvoert heeft te maken met een toenemende accommodatie tussen het juridisch bestel en degenen die er een beroep op doen ('legal rationalization'). Kagan doelt daarmee op het geleidelijk toenemen van de duidelijkheid over de juridische aspecten van een min of meer omlijnde thematiek, zoals bijvoorbeeld kredietverlening en incasso. Wetgeving, jurisprudentic en aangescherpte standaardcontracten gaven minder ruimte tot procederen omdat de uitkomst beter voorspelbaar wordt. Als tweede factor, die hij van invloed acht op de waargenomen ontwikkeling, noemt Kagan politieke interventie ten aanzien van veel voorkomende schuldproblemen. Als derde factor wees Kagan op zoiets als de institutionele 'stabilisering' van de verhouding tussen politicke en economische krachten. ${ }^{24}$ Dergelijke historische ontwikkelingen staan in het volgende niet op de voorgrond, al zal er bij gelegenheid wel naar verwezen worden. Hier zal de aandacht vooral uitgaan naar de vorming van relaties tussen bedrijven onderling. De institutionele context figureert in ieder geval in eerste instantie als 'gegeven omstandigheden'. Hun ontwikkeling is niet het hoofdonderwerp van dit onderzoek.

\section{De juridische infrastructuur}

Het tweede rechtssociologische thema waar het onderzoek bij kan aanhaken, betreft de discussie over de verklaring van internationale verschillen in "litigation rates'. Het gaat daarbij om vergelijkingen van in eerste instantie op justitiële statistieken gebaseerde cijfers over de aantallen gerechtelijke procedures die per 100.000 inwoners in een bepaalde periode zijn aanhangig gemaakt. Naar aanleiding van opmerkelijke contrasten rijst dan de vraag hoe deze verschillen zijn te verklaren. In de rechtssociologische literatuur zijn verschillende benaderingen

24 Kagan spreekt van "systemic stabilization". Het is een (naar hij zelf ook toegeeft) wat vage term. waarmee waarschijnlijk zoiets bedoeld is als: "geternd kapitalisme" of de verzorgingsstaat. In "moderne democratische en kapitalistische maatschappijen" - zo stelt Kagan - zijn eisen op de politicke agenda's gekomen die waarden weerspiegelen als rationele oplossing van collectieve problemen en stabiele en effectieve economische markten. Dit heeft in dergelijke samenlevingen geresulteerd in: "the development of large-scale economic and social institutions that ameliorate the conditions that cause individual conflicts or that provide collective, administrative remedies (as contrasted to case-by-case legal remedies)." (Ibid., p. 352) Uit de opsomming die dan volgr, blijkt dat Kagan een complex op het oog heeft van: regulering van de financiele sector (banken en verzekeringen), betrouwbare credietfaciliteiten en voorzieningen op het gebied van sociale zekerheid. 
aan te treffen, die ieder een andere factor of complex van factoren aanwijzen als meest bepalend voor de variatie in het beroep op de (in hoofdzaak civiele) rechter.

\subsection{Cultuur}

De hier bedoelde discussie vindt waarschijnlijk (althans buiten Japan) zijn oorsprong in een artikel van Kawashima waarin hij het klaarblijkelijk lage niveau van het gebruik van rechtspraak in Japan (in vergelijking met dat in het Westen) heeft getracht te verklaren. De verklaring zoekt hij vooral in de kenmerkende voorkeur van Japanners voor buitengerechtelijke geschilbeslechting, die als een voortvloeisel te beschouwen is van het karakter van traditionele grocpsverhoudingen in Japan. ${ }^{25}$ Dergelijke verhoudingen zijn hiërarchisch maar tevens patriarchaal (niet despotisch) van aard en gemodelleerd naar familieverhoudingen. De hiërarchisch hoger geplaatste heeft niet alleen overwicht over, maar ook zorg voor, de ondergeschikte. Verzoeken van de ondergeschikte worden verondersteld althans gedeeltelijk te worden ingewilligd. Dat geldt niet alleen voor verhoudingen in de dorpsgemeente en de familie maar ook voor contractuele verhoudingen. Complementaire rollen, zoals die van koper en verkoper, huurder en verhuurder, werkgever en werknemer, zijn dientengevolge moeilijk in algemene termen te omschrijven. Ze moeten, afhankelijk van de omstandigheden, in het besef van onderlinge afhankelijkheid en in harmonie worden ingevuld. Hetzelfde geldt overigens mutatis mutandis voor de verhouding tussen gelijken. Geschillen horen in dergelijke sociale verhoudingen eigenlijk niet voor te komen. En als dat toch gebeurt dan dienen ze in onderling overleg te worden opgelost. De door Kawashima geschetste verhoudingen verdragen zich derhalve slecht met rechterlijke beslissingen, die het bestaan van een geschil accentueren en die tot stand komen op grond van abstracte standaarden die onafhankelijk zijn van de wensen van partijen en waarbij de kans groot is dat een van de partijen als 'winnaar' uit de bus komt. Dit verklaart ten dele de populariteit van bemiddeling en arbitrage. Daar komt bij dat rechters in Japan ook een akkoord tussen partijen prefereren boven een rechterlijke beslissing, wat vaak leidt tot langdurige en kostbare processen:

"A lawsuit takes more time, and more expense, terminates the harmonious relationship between the parties, and gives the plaintiff just as little as, or quite often less than, what he would obtain through extrajuducial means. Who would resort to a lawsuit in view of these disadvantages except pugnatious, litigious fellows?" 26

25 Kawashima (1964) Dispute resolution.

26 Ibid., p. 49. 
Deze sociale logica geldt overigens niet voor alle relaties. Kawashima kwalificeer. de het door hem geschetste beeld uitdrukkelijk als niet toepasselijk voor relatie tussen groepen onderling en voor die tussen geldschieters en hun debiteuren. In dergelijke relaties is een harde confrontatie niet buiten de orde.

Latere critici van Kawashima hebben zijn these soms opgevat als uitsluitend betrekking hebbend op houdingselementen die kenmerkend zijn voor de Japanners (afkeer van, voorkeur voor). Daarmee zou men Kawashima echter tekon doen, zo stellen andere interpreten. De verklaring van Kawashima omvat volgens Rokumoto meer dan alleen houdingselementen van individuele mensen ten aanzien van procederen. ${ }^{27} \mathrm{Ze}$ verwijst volgens Rokumoto naar een meer omvattend begrip van 'cultuur', dat de volgende elementen omvat: "1) a system of symbolic meaning, 2) with features distinctive to a society (or a social group), 3) that forms the basic, common model for the particular awareness, values, and opinions by its members." 28

\subsection{Aanbod}

Een bekende kritiek op de positie van Kawashima en anderen is die van Haley. Het werk van Kawashima heeft volgens hem bijgedragen tot de ontwikkeling van het beeld van Japanners als uitzonderlijk 'non-litigeous'.

"Commentators, both within and without Japan, are almost unanimous in attributing to the Japanese an unusual and deeply rooted preference for informal, medi. ated settlement of private disputes and a corollary aversion to the formal mechanisms of judicial adjudication ${ }^{20}$

Haley heeft deze these over het proceduremijdende gedrag van Japanners aan de kaak gesteld als een mythe. De argumenten waarop Haley zijn stelling baseert luiden in hoofdzaak als volgt. Voor zover 'litigeousness' verwijst naar het feitelijk ge bruik van rechtspraak, is het onmiskenbaar, dat Japan in vergelijking met de Verenigde Staten als 'non-litigeous' moet worden gekwalificeerd. In vergelijking met andere landen is dat echter niet of in veel mindere mate het geval. Maar - zo stelt Haley - met 'non-litigeous' wordt meestal ook iets anders bedoeld, namelijk een afkeer van procederen. In dit opzicht zijn Japanners niet noodzakelijk anders dan anderen. Voor de meeste mensen is procederen een ultimum remedium vanwege de kosten die er zowel in materiële als immateriële zin aan verbonden zijn. Vandaar ook dat de overgrote meerderheid van de geschillen in de meeste samen-

27 Rokumoto (1995) Cultunal factors in companative socio-logal analysis, p. 68. Zie ook: Miyazawa (1987) Taking Kanwshima seriousty.

28 Ibid., p. 73.

29 Haley (1978) The Myth, p. 359 
levingen informeel worden afgehandeld: "traditional moral censure of litigation is arguably as Christian as it is Confucian" ${ }^{30}$ De veronderstelde afkeer van Japanners ten aanzien van procederen mist volgens Haley empirische fundering, sterker: het empirisch materiaal dat aanwerig is wijst op het tegendeel. Het opmerkelijk gegeven, dat gedurende de periode na de Tweede Wereldoorlog de litigation-rate voor civielrechtelijke zaken - anders dan men volgens de orthodoxe opvatting gezien de modernisering van Japan zou mogen verwachten - sterk afnam in verhouding tot die uit de vooroorlogse periode, was volgens Haley voornamelijk het gevolg van de in die periode sterk gereduceerde beschikbaarheid van justitiêle voorzieningen als advocaten, rechters en procedures. Die reductie is volgens Haley politiek georkestreerd en heeft weinig te maken met de opvattingen van Japanse burgers. Tengevolge van de beperking van het aanbod van voorzieningen is de vraag ernaar gedaald. Daarbij geven de Japanners er blijk van, net als bewoners van andere landen, kosten en baten van gerechtelijke stappen af te wegen. In de periode voor de oorlog vielen die afwegingen door een groter aanbod van voorzieningen anders uit dan na de oorlog, toen het aanbod werd beperkt.

De verklaring van Haley is ook interessant in het licht van de in het vorige hoofdstuk geschetste 'state-centered' invalshoek. Er is niet alleen aandacht voor de invloed van de vraagzijde bij de vorming en het gebruik van juridische instellingen, maar ook voor die van de aanbodzijde. Dit is een element dat in de benadering van Kawashima en zijn geestverwanten niet aan de orde komt. Het is tegelijk ook een correctie op een deterministische en statische opvatting van (nationale) cultuur. De bevindingen van Haley sluiten bijvoorbeeld goed aan op de door Van Wolferen geschetste propagandistische acties van de kant van wat hij het politieke 'Systeem' noemt (een figuratie van politieke, ambtelijke en industriële elites) ten aanzien van de 'ideologie van het Japans-zijn'. ${ }^{31}$ Wat de Japanse 'cultuur' inhoudt, is volgens Van Wolferen voor een belangrijk deel het product van officiële propaganda over wat Japans-zijn inhoudt, ook waar het de gang naar de rechter betreft:

'De 'cultuur' maakt overuren om de motieven van iedere Japanner onder alle omstandigheden te verklaren. Soms is de implicatie bijna dat het Japanse individu geen andere motieven kent dan die welke hem door de cultuur zijn ingeplant, alsof iedereen onderworpen is aan een of ander autonoom zenuwstelsel. In de heersende, officieel gepropageerde opvatting offeren de Japanners zichzelf en hun gezinsleven op aan hun bedrijf, niet omdat dit voor het bedrijf expansie mogelijk maakt tegen een minimum aan kosten, maar omdat hun cultuur hun zegt zich voor de groep op 
te offeren. Zij stemmen toe in een buitengerechtelijke schikking van een conflict vanwege hun culturele afkeer van rechtbanken en advocaten, niet omdat het mi. nisterie van justitie het aantal rechters en advocaten beperkt tot een fractie van wat nodig is voor het functioneren van een modern rechtsstelsel."

Daarbij rijst als vanzelf de vraag waarom deze activiteiten aan de aanbodzijde zijn ondernomen. Het antwoord moet gezocht worden in de (geo-)politieke geschiedenis van Japan.

Deze praktijken hebben wortel geschoten in de periode van het Togukawa-regime (1600-1867). Ze werden met nieuwe energie opgepakt na de vorming van de Japanse nationale staat in de tweede helft van de negentiende eeuw. ${ }^{33} \mathrm{De}$ moderniseringsoperatie die bekend staat als de Meiji Restauratie was een indrukwekkende inhaalslag ten opzichte van het moderne Westen en bedoeld om de geopoliticke automie van Japan zoveel mogelijk van aantasting door imperialistische grootmachten te vrijwaren. De modernisering hield ondermeer de introductie in van op westerse leest geschoeid recht. Dergelijke buitenlandse invloeden wekten wel de vrees dat het bestaande plichtsbesef en de bereidheid tot zelfopoffering van de bevolking door 'onjapanse' denkbeelden (zoals bijvoorbeeld 'subjectief recht') zouden worden ondermijnd. ${ }^{34}$ De ideologie van het Japans-zijn en daarbij passende institutionele voorzieningen moesten dit voorkomen. Het geschetste gevaar werd met name gevreesd toen Japan na de Tweede Wereldoorlog voor het eerst in haar geschiedenis door een vreemde mogendheid werd bezet. De Amerikaanse bezettende autoriteiten besloten tot een hervorming van het juridisch bestel op Amerikaanse leest. Deze erfenis heeft in de naoorlogse periode een rol gespeeld in de confrontaties tussen enerzijds conservatieve krachten, die dit recht hebben getracht te hervormen naar de Japanse 'traditie' en progressieve groeperingen die in dit streven een bedreiging zagen. ${ }^{35}$ In dat kader moeten de door Van Wolferen gesignaleerde propaganda en de door Haley bedoelde institutionele manipulaties worden begrepen.

Over de invloed van deze initiatieven wordt verschillend geoordeeld. Het is aannemelijk dat dergelijke propagandistische activiteiten aansloten bij - door een groot deel van de bevolking - geprefereerde concepties van sociale verhoudingen en omgangsvormen. Maar uit die steun mag niet worden afgeleid dat die opstelling door iedereen gedeeld is. ${ }^{36}$ Het huldigen van 'de traditie' is nooit onomstre-

\section{Ibid. p. 407.}

33 Mitchel (1976) Thought control in preusar Japan, passim.

34 Peters (1982) Eurocentriom in law, p. 92.

35 Peters (1993) Recht en samenleving in Japan.

36 De claim van volstrekte homogeniteit vormt een onderded van het verhaal over "Japans-zijn", Oppositionele groeperingen en (aanzienlijke) minderheden worden daarbij aan het zicht 
den geweest. Weer anderen zullen zich aan de gegeven omstandigheden hebben angepast. Dat is overigens des te gemakkelijker naarmate de nadelige gevolgen van dit aspect van het 'Japans-zijn' worden geneutraliseerd door aantrekkelijke alternatieven voor het afhandelen van claims en geschillen. ${ }^{37} \mathrm{Zo}$ is rationeel handelen tevens ook correct handelen. De positie van Kawashima valt zo, voorzien van kwalificaties, misschien nog wel te rijmen met die van Haley. ${ }^{38}$

Het accent dat Haley in het aangehaalde artikel heeft gelegd op de 'aanbodzijde', komt sterk overeen met de benadering die Blankenburg en Verwoerd hebben ontwikkeld ter verklaring van de verschillen tussen Nederland en Duitsland (Nordrhein-Westfalen) wat betreft het 'beroep op de rechter'. ${ }^{39}$ De verschillen zouden volgens deze schrijvers vooral zijn terug te voeren op de 'organisatic van het aanbod' van rechtshulpverlenende en gerechtelijke voorzieningen. De organisatie van juridische advisering (met name de monopoliepositie van de advocatuur), capaciteit en competentie van de rechterlijke macht en de beschikbaarheid van alternatieve instellingen voor geschillenbeslechting, wijzen zij aan als omstandigheden met veel invloed op de koers die men ten aanzien van geschillen kiest. Door de bestaande institutionele arrangementen worden Duitsers ertoe aangezet een beroep te doen op advocaten en gerechten en de ingeslagen juridische route vasthoudend te vervolgen, waar Nederlanders worden gestimuleerd hun geschillen buiten rechte af te doen en eventueel een beroep te doen op alternatieve fora voor geschilbehandeling. Blankenburg meent zelfs, dat deze institutionele arrangementen van doorslaggevende invloed zijn op de vorming van de 'vraag' naar gerechtelijke procedures: "Avoidance of litigation can be institutionally induced, just as can litigiousness. ${ }^{40}$

Dit is voor het onderhavige onderwerp een interessante stelling. Ze roept direct de vraag op of dan bijvoorbeeld ook de methodische preventie van klachten en geschillen in relaties tussen bedrijven in enige mate afhankelijk is van de geboden institutionele infrastructuur voor 'geschilbehandeling'. De redenering zou kunnen zijn dat, wanneer die faciliteiten om wat voor reden ook schaars en kostbaar zijn, er meer aanleiding zal zijn om reflexieve methoden te gebruiken; wan-

onttrokken. Cf. Van Wolferen, t.a.p., p. 441.

37 Cf. Tanase (1990) The management of disputes, en ook Ramsayer (1990) Reluctant litigant revisited.

38 Dat lijkt de meest recente positic van Haley te zijn in (1991) Authority without power, zic ook zijn reactie (1993) A response op de bespreking van Johnson (1993) Haley on Japan's law and politic.

39 Zie o.a: Blankenburg (1985) Indikatorenvergleich der Rechtskulturen in der Bundesrepublik und den Niederlanden; Verwoerd (1988) Beroep op de rechter als laatste remedie.

40 Blankenburg (1991), Legal cultures compared, p. 20. 
neer die faciliteiten echter ruim voorhanden en goedkoop zijn dan zullen dit omstandigheden minder snel de stimulans zijn tot de inzet van die methoden.

Tegelijkertijd heeft de these van Blankenburg een enigszins provocerend ka. rakter. Een eerste tegenwerping kan zijn dat de stelling niet ver genoeg reikt. Men gaat niet ver genoeg met een dergelijke verklaring van de verschillen tussen $\mathrm{Ne}$. derland en (een deel van) Duitsland omdat voor de hand liggende vragen niet worden gesteld en dus geen voorwerp van onderzoek worden. Die vragen hebben betrekking op het hoe en waarom aan de justitiële infrastructuur op een bepaalde manier is vormgegeven. Waarom zou dat in Nederland anders zijn gegaan dan in Duirsland? Wat hebben de 'aanbieders' daarmee voor gehad? Deze vragen lijken te verdwijnen in het begrip 'rechtscultuur'. Dat begrip omvat (volgens Blankenburg) de onderlinge betrekkingen van drie niveaus van het juridisch bestel: 1) het materieel en formeel recht, 2) de instanties, zoals de gerechten en de rechtshulpverlening en 3) het 'legal behavior' en houdingen ten opzichte van 'het recht'. Litigation-rates worden beschouwd als indicatoren van dit complex. Verschillen in deze indicatoren kunnen worden herleid tot dit complex. Blankenburg opponeert daarbij tegen de verklaring van gesignaleerde verschillen met een beroep op zoiets als houdingen of mentaliteit ('attitudinal culture'):

"In our comparison of The Netherlands and Germany, whose cultures are so much alike, we need offer no explanation for differences in litigation rates on the basis of 'folk mentality'. The decisions of plaintiffs to use or avoid courts are based on similar strategic reasons on both sides of the border. "I

Maar ook al zou dat zo zijn, dan nog blijft de vraag staan naar de wording van het institutionele aanbod. Die vraag is (zoals voor Japan) nader onderzoek waard, tenzij er van wordt uitgegaan dat de vorming van de juridische infrastructuur een volledig contingent proces is. Nu kan dat in een concrete casus het geval zijn, maar het kan niet a-priori worden aangenomen. Voor Nederland en Duitsland bijvoorbeeld zijn enkele verklaringen geopperd. ${ }^{42}$ We zullen deze kwestie hier verder laten rusten, want deze kwestie ligt buiten het bestek van het onderzoek.

41 Blankenburg (1994) The infrastructure for avoiding litigation, p. 807.

42 De vragen die aan het oog worden onttrokken zijn zeer intrigerend. En ook de speculaties over mogelijke antwoorden vragen naar meer. Ook hier komt men uit bij de politicke geschiedenis van de betreffende landen en onder meer ook bij international-politieke invloeden. Wat Duitsland betreft is gewezen op de afschaffing van de nationaal-socialistische informele (partii)procedures die na zich W.O. II onder supervisie van de geallieerden heeft voltrokken. Cf. Nelken (1998) Pueseling out logal culthere. En wat Nederland betreft is bijvoorbeeld gewezen op de introductie van een administratieve ontslagprocedure tijdens de Duitse bezetting die na de oorlog is overgenomen (art. 6 B.B.A.) en dic (vooralsnog) een belangrijk onderded vormt van de Nederlandse "infrastructure of avoidance". Cf. Jetringhoff (1995) The politics of procedure. 
Anderzijds lijkt de stelling ook weer te ver te reiken. Ze stelt de vraagzijde voor als een volledig afhankelijke grootheid. De redenering is dat bepaalde patronen van geschilbehandeling zich in de loop der tijd uitkristalliseren en dat de juridische infrastructuur de vormende kracht van die patronen is. Als er naar aanleiding van geschillen actie wordt overwogen, worden de strategische calculaties van de kosten en baten van de eisers door de institutionele omgeving gestuurd. Daarvan is afhankelijk of een beroep op de rechter wordt gedaan of niet. Zo ontstaat een bepaalde 'legal culture'. Op zich is de veronderstelling dat het bestel van juridische voorzieningen van invloed is op patronen van geschilbehandeling nogal plausibel. Maar de stelling is hier dat ze een voldoende verklaring van die patronen zijn. Kenmerken van de vraagzijde worden als niet of nauwelijks van betekenis beschouwd voor het verklaren van de verschillen tussen landen wat betreft de frequenties van het beroep op de burgerlijke rechter.

De beperkingen van het voorliggende onderzoek laten het uiteraard niet toe om dergelijke uitspraken over verschillen in landelijke totaalcijfers te controleren. Want de mate van 'vermijden' waarvan in het werk van Blankenburg sprake is, betreft gedrag zoals dat uit statistisch materiaal naar voren komt. In dit onderzoek is in ieder geval niet geprobeerd kwantitatief materiaal te verzamelen. Maar 'vermijden' impliceert meestal ook een betekeniselement: om enige reden wordt iets niet gedaan of ontlopen en in de plaats daarvan wordt eventueel iets anders gedaan. ${ }^{43}$ Ten aanzien van die redenen neemt Blankenburg stellenderwijs enkele dingen aan. In de eerste plaats neemt hij aan dat het gedrag niets te maken heeft met een bepaalde houding ten aanzien van het doen van gerechtelijke stappen. In de tweede plaats stelt hij dat de strategische afwegingen, die eisende partijen maken ten aanzien van de opties die ze hebben, de verschillen tussen de landen verklaren:

"The decisions of plaintiffs to use or avoid courts are based on similar strategic reasons on both sides of the border. What differs are the incentives their respective legal systems offer" +4

De opmerking van Nelken, dat het hier gaat om onbewezen assumpties lijkt me correct. ${ }^{45}$ Juist op de achtergronden voor 'vermijden' kan - voor de beperkte 'wereldjes' die hier aan de orde zijn - met het hier verzamelde kwalitatieve materiaal mogelijk wel meer zicht worden verkregen. De these van Blankenburg roept voor de praktijken die in dit onderzoek centraal staat, enkele vragen op.

Een eerste (hiervoor al genoemde) vraag is of soms ook het hanteren van reflexieve methoden voor het voorkomen van klachten en geschillen afhankelijk is 
van (dat wil hier zeggen: een reactie op) kenmerken (verwachte kosten en baten) van de juridische infrastructuur. Een tweede kwestie betreft de gewicht dat de (gepercipieerde) juridische infrastructuur in de schaal legt bij de manier waarop men besluit gerezen geschillen aan te pakken. Is het werkelijk zo dat als geschillen ontstaan, uitsluitend de kenmerken van een juridische infrastructuur bepalen of en hoe vaak gerechtelijke stappen worden ondernomen of spelen daarin nog andere overwegingen mee?

\section{Onderzoeksopzet}

\section{Een contextuele benadering: de logica van het ondernemen}

De onderzoeksopzet is geïnspireerd door de benadering die Van der Veen heeft gehanteerd bij zijn onderzoek naar de uitvoering en effecten van sociale zekerheid. ${ }^{46}$ Daar probeert hij het handelen van cliënten van sociale-zekerheidsinstanties te verklaren als 'logische', rationele reacties op de sociale context waarin ze zich geplaatst weten (hun duurzame uitkeringsafhankelijke leefsituatie).

"De uitkeringsafpankelijke situatie wordt gekenmerkt door onmacht aan de kant van de cliënt, afhankelijkheid van de beslissing van anderen (ambtenaren), zwakke relaties tussen lotgenoten en een weinig gerespecteerde maatschappelijke positie. " Aan de hand van deze kenmerken van hun positie in een netwerk van betrekking. en kunnen zowel het handelen van de cliënten als de morele en strategische overwegingen waarmee ze het rechtvaardigen worden verklaard.

In dit onderzoek is naar antwoorden op de gestelde vragen gezocht door middel van interviews met bedrijfsleiders of hun naaste medewerkers teneinde een beeld te verkrijgen van de omstandigheden waarin ondernemers aanleiding zien om op een methodische manier om te gaan met mogelijke zakelijke conflictstof. Deze omstandigheden vormen, in combinatie met hetgeen de ondernemer wil bereiken, de 'logica' van de positie van de ondernemer - het redengevende kader voor zijn handelen.

In zijn elementaire gedaante kan bedrijfsmatig ondernemen omschreven wor den als het planmatig en permanent mobiliseren en coördineren van mensen en middelen ter voortbrenging van een product met het oog op de per saldo rendabe le afzet ervan. Vanuit deze optiek is de ondernemer (of het management) te situe 
ren in een webachtige figuratie van relaties met organisaties en instanties, sommigen dichtbij, anderen meer op afstand. ${ }^{48}$ Dichtbij valt te denken aan het personeel, de klanten, toeleveranciers. Wat verderaf staan de financiers, verzekeraars, accountants, belangenorganisaties. Ook heeft men nog rekening te houden met concurrenten en een diversiteit van 'overheden'. Ten aanzien van sommige van deze relaties heeft de ondernemer meer mogelijkheid relaties te kiezen dan ten opzichte van andere. Ook is het mogelijk dat de onderneming zelf een onderdeel is van een groter conglomeraat waaraan verantwoording moet worden afgelegd. Voor het succes van de onderneming is men in meerdere of mindere mate op deze actoren aangewezen. Over het algemeen zal gelden dat die afhankelijkheid wederkerig is; ook de ander is op de onderneming min of meer aangewezen: de werknemers voor hun loon, de toeleveranciers voor de klandizie, de klanten voor de toelevering, enzovoorts. Met andere woorden: het zijn afhankelijkheidsrelaties. Deze afhankelijkheidsrelaties kunnen ook onderling verbonden zijn. Dat wil zeggen dat wanneer er met de transacties binnen één relatie iets fout gaat dit repercussies kan hebben voor de transacties met verschillende andere. Deze afhankelijkheidsrelaties zijn variabel, ze kunnen als 'machtsbalansen' opgevat worden. ${ }^{49}$ In formeel opzicht moge aan de fictie van de 'gelijke contractspartners' worden gerefereerd, maar dat betekent niet dat ieder ook in feite evenveel noten op zijn zang kan hebben. Zo is bijvoorbeeld het gezegde "de klant is koning" in het bedrijfsleven geen loze kreet. En binnen dat gegeven bestaan weer grote verschillen. We zullen nog zien dat sommige contractuele relaties met klanten sterk 'hiërarchische' trekken vertonen.

Deze sociale context vormt een belangrijk deel van het bestek waarin het management zijn opdracht moet zien te volbrengen. Een ander deel bestaat uit 'materiële' gegevenheden waarmee gewerkt moet worden, zoals de mogelijkheden die bestaan op het vlak van betalingsverkeer, productietechnologie en logistiek.

Het was praktisch gesproken onmogelijk en voor de vraagstelling ook niet nodig om het omgaan met conflictstof in alle mogelijke relaties in beeld te brengen. Ook de voor het interview doorgaans beschikbare tijd maakte een keuze noodzakelijk. Er is gekozen voor een beperkt aantal relaties: de toeleveranciers en de klanten als de voornaamste van de relaties tussen bedrijven. Daarnaast zijn de re-

48 Dit is ook een zienswijze die in de economische sociologie sterk benadrukt wordt. Er wordt daar gesproken van de 'embeddedness' van het economisch handelen: 'Actors do not behave or decide as atoms outside a social context. Nor do they adhere slavishly to a script written for them by the particular intersection of social categories that they happen to occupy. Their attenpts at purposive action are instead embedded in concrete, ongoing systems of social relations.' Granovetter (1985) Economic action and social structure, p. 487.

49 Cf. Elias (1971) Wat is sociologie, p. 79 e.v. 
laties met de concurrenten in het onderzoek betrokken, met name met het oog op de suggesties van Galanter en Rogers over de veranderde situatie op dit vlak. De spelers die in het onderzoeksverslag worden opgevoerd zijn meestal aangeduid met de naam van hun positie ten opzichte van de onderneming die is ondervraagd. Deze onderneming zelf in het vervolg aangeduid als 'het bedrijf en daarnaast verschijnen 'de leverancier', 'de klant' of 'de opdrachtgever' en ten slotte 'de concurrent'. Daarmee is ook de hoofdstructuur van de interviewagenda gegeven die in paragraaf 6 aan de orde komt.

\section{Over storingen, klachten, geschillen en juridische stappen}

In de rechtssociologische literatuur is veel aandacht besteed aan de benoeming en omschrijving van wat een rechtsprobleem is. Het gaat om het soort gebeurtenissen of toestanden waarmee betrokkenen rechtshulp zouden kunnen inschakelen of naar de rechter zouden kunnen stappen. De gedachte dat het hier om een bepaald soort problemen zou gaan is alras verlaten. Er is niets wezenlijk 'juridisch' aan een rechtsprobleem. Wat een probleem een rechtsprobleem maakt is dat men ernaar kijkt met een juridische bril, het onderzoekt in termen van geldend recht. In die zin is vrijwel elk probleem een mogelijk rechtsprobleem. Het pragmatische aspect van de transformatie van een probleem tot een rechtsprobleem is belangrijk. Meestal ontwikkelen zich in de loop der tijd bepaalde conventies over wat normaliter als een rechtsprobleem beschouwd kan worden, dat wil zeggen een probleem waarvan het mogelijk de moeite loont er 'juridische stappen' in te ondernemen; het kan ook zijn dat er nauwelijks aan te ontkomen is omdat er geen andere optie dan deze voorhanden is, afgezien van berusting. ${ }^{50}$

In de 'dispute-literatuur' is veel moeite gedaan om alle voorstadia van juridische geschillen te benoemen. Het hele traject van de kiem van het geschil tot aan de gerechtelijke procedure en alle transformaties die zich onderweg aan het geschil-in-wording voltrekken heeft men getracht in kaart te brengen. Beroemd is het traject dat door Felstiner, Abel en Sarat hebben uitgezet. ${ }^{51} \mathrm{Zij}$ hebben het subjectieve karakter van geschillen sterk benadrukt: het zijn geen dingen, maar sociale constructies. De ontwikkeling van het probleem is vooral afhankelijk van

50 Dit is de uitkomst van het proces dat Blankenburg "rechtscultuur" noemt; het doet ook denken aan de 'legal rationalisation' van Kagan. Zie ook: Blankenburg en Reifner (1982) Rechtsberatung p. 294 e.v.

51 Felstiner, Abel en Sarat (1980) The transformation of disputes. Zie ook: Pieterman (1998) Dubbeleinnig moth. p. 90 c.v. 
de oordelen van de betrokkenen. Felstiner c.s. noemen de kiem van een geschil een "perceived injurious experience" en de eerste transformatie bestaat vervolgens uit de benoeming van die ervaring als een probleem ('naming'). Als daarop mogelijk volgende transformaties noemen zij: het voor het probleem verantwoordelijk houden van een ander ('blaming') en daarna het aanspreken van die ander en het vragen of eisen van een remedie of compensatie ('claiming'). Wanneer de aangesproken partij daarmee niet akkoord gaat en de ander bij zijn eisen blijft, ontstaat er een geschil of een conflict. ${ }^{52}$

Er kan ook nog een iets andere - in zijn algemeenheid overigens niet aantrekkelijker - benadering gehanteerd worden. Deze invalshoek is ontleend aan een criminologische studie naar het omgaan met criminaliteit. ${ }^{53}$ Het uitgangspunt van deze studie was de voorkeur van mensen voor het volgens bepaalde verwachtingspatronen verlopen van veel alledaagse gebeurtenissen en activiteiten. ${ }^{54}$ Dat ordent het leven van alledag en vergemakkelijkt het aanzienlijk. De doorbreking van deze routines kan ervaren worden als een problematische storing van de routine. Of dat zo is hangt af van wat mensen verwachten, van wat hun referentiekader is. Dergelijke storingen kunnen aan mensen als storingsbron worden toegeschreven of niet. En met die mensen kan een relatie bestaan of niet. Met name de storingen binnen het kader van een relatie zijn in het verband van dit onderzoek interessant. Wat in een relatie een problematische storing is hangt af van het type relatie en van hetgeen daarin 'normaal' gesproken te verwachten is. Met leveranciers en klanten worden ruilrelaties onderhouden waarvoor het element van expliciete planning, gericht op een min of meer welomlijnde activiteiten en resultaten, kenmerkend is. De meest voor de hand liggende veronderstelling kan zijn dat het niet-nakomen van afspraken een storing van de planning zal zijn, die aanleiding kan zijn tot klachten en eventueel conflicten. ${ }^{55}$

Het beginpunt zijn de 'storingen' in de geplande gang van zaken. Wanneer een relatie in verband met een storing wordt aangesproken zullen we hier spreken van een 'klacht'. Veelal zal dat in het volgende betekenen dat de begrippen op hetzelfde neerkomen. De volgende transformatie wordt overeenkomstig de eerdere omschrijving een 'conflict' of 'geschil' genoemd. Het aantal stappen in het traject is beperkt gehouden om de eigen definities niet al te zwaar aan te zetten: mogelijk gaat het in de praktijk anders.

Wat als een 'probleem' geldt is afhankelijk van de waardering van betrokkenen en derhalve (zoals gezegd) moeilijk objectief vast te stellen. Het zoeken naar een

52 Pieterman, t.a.p., p. 93.

53 Hanak, Stehr en Steinert (1989) Angernisse und Lebenskatastrophen.

54 Ibid, p. 5 e.v.

55 De 'relaties' met concurrenten verlopen waarschijnlijk heel anders, de vraag is alleen hoe. 
objectieve maatstaf kan zijn ingegeven door meer praktische, onderzoekstechnische overwegingen. Met name in extensief survey-onderzoek wordt dan (meestal per probleemveld) een objectief waarneembaar gegeven gekozen dat als uitgangspunt, standaard (base-line) kan dienen om het aantal claims, beroepen op rechtshulpverleners en procedures tegen af te zetten. Een dergelijke strategie is voor dit type onderzoek goed verdedigbaar. Middels kwantitatieve analyse kan dan getracht worden de invloed van bepaalde variabelen (zoals bijvoorbeeld de invloed van rechtsregels, de infrastructuur van de rechtshulpverlening, procedurele mogelijkheden en dergelijke) te traceren. Aan het geheel voordefiniëren van (rechts)problemen kleeft onder meer het bezwaar, dat respondenten niet noodzakelijk in de termen van de onderzoeker denken. ${ }^{56}$ Meestal zoekt men een hanteerbaar compromis tussen enerzijds het aandragen van bepaalde situaties of problemen door de onderzoeker, waarvan hij mag aannemen dat ze door de respondenten als problematisch zullen worden ervaren en aanleiding kunnen geven tot een beroep op rechtshulpverlening en juridische stappen en anderzijds het oordeel van de respondent of zich in een bepaalde situatie al dan niet een probleem heeft voorgedaan. ${ }^{57}$ Zoals hierna zal blijken is hier ook min of meer een zelfde tactick toegepast om misverstanden met de respondenten te voorkomen en antwoorden enigszins vergelijkbaar te houden.

Het in kaart brengen van alle 'juridische stappen' (vanaf het inschakelen van juridische bijstand) die in een bepaalde periode zijn gedaan bleek in de interviews moeilijk hanteerbaar. Daarom is vooral gevraagd naar de beperkter categorie 'gerechtelijke stappen' (inclusief arbitrage), dat wil zeggen: gevallen waarin een gerechtelijke procedure is overwogen of daadwerkelijk gestart.

\section{De interview-agenda}

De interviewagenda is samengesteld uit enkele segmenten van gespreksitems:

\section{1. over 'het bedrijf zelf}

- enkele kerngegevens over het bedrijf.

- een korte van de historie van het bedrijf.

- kenschets van de structuur van het bedrijf.

- een beschrijving van de belangrijkste producten en het productieproces.

S6 CBS (1991) Recbosbulp in Nederland, p. 8

57 Cf. Schuyt, Groenendijk en Sloot (1976) De weg naar het recht, p. 123 e.v.; Klijn (1991) Recheshulp ovendacht, p. 254. 


\section{2 en 3 over de 'leveranciers' en 'klanten'}

- de duurzaamheid van de relaties.

- de frequentie en behandeling van enkele categorieèn klachten.

- gebruik en aard van methoden van behandeling en preventie van klachten.

\section{4. over de 'concurrenten'}

- de bekendheid en het eventuele contact met concurrenten.

- de frequentie en behandeling van klachten, preventieve werkwijzen.

\section{5. over het doen van juridische stappen}

- beschrijving van casus waarin gerechtelijke stappen zijn gedaan of overwogen.

- overwegingen bij het afzien van of de keuze van opties voor de afhandeling van geschillen.

- verloop, duur en afloop.

De segmenten 2 en 3 zijn enigszins voorgestructureerd met een klein aantal mogelijk veel voorkomende problemen in de sfeer van wat in het juridisch jargon 'tekortkoming' wordt genoemd: niet-nakoming, ondeugdelijke nakoming, te late nakoming. Een open vraag zou de rest moeten vangen.

\section{Keuze van bedrijfstakken}

De selectie van te benaderen bedrijven is niet willekeurig gegaan. In de eerste plaats is besloten om ondernemingen uit het midden- en kleinbedrijf te benaderen. In dergelijke bedrijven heeft het management doorgaans een redelijk precies beeld van wat er in het bedrijf op werkvloerniveau omgaat, in ieder geval meer dan dat het geval zal zijn bij grote ondernemingen. Zo zou waarschijnlijk met één gesprek per bedrijf volstaan kunnen worden. Voorts zou een geheel willekeurige selectie het moeilijk maken een beeld te construeren van de 'logica van het ondernemen', die typerend is voor bedrijven, die min of meer in vergelijkbare omstandigheden opereren. Er zijn daarom telkens een aantal bedrijven uit een bedrijfstak bevraagd. Dit zou door onderlinge vergelijking een typering mogelijk moeten maken. De vraag is dan welke bedrijfstakken te kiezen.

Een kernelement in de onderzoeksopzet was de selectie van branches die duidelijk meer of minder conflictrijk zijn in hun commerciële relaties. Geprobeerd is bedrijfstakken te vinden die in dit opzicht duidelijk contrasteren, in de verwachting dat door vergelijking van contrasten meer inzicht zou kunnen worden verkregen over de achtergronden van die contrasten en de mogelijke rol van reflexieve methoden daarbij. Een ander, minder prominent element was - met het oog op de these van Galanter en Rogers - de verzorging van enige variatie wat be- 
treft het internationaal, respectievelijk nationaal of regionaal actief zijn van de bedrijven. Aan de hand van impressies van enkele lokale rechtshulpverleners en gegevens van de Kamer van Koophandel is een eerste selectie van branches gemaakt. Van de aannemerij werd gezegd dat er veel conflicten in voorkwamen. Ten aanzien van de softwarebedrijven bestond dezelfde verwachting, op grond van de overweging dat in nieuwe bedrijfstakken aanvankelijk 'wild-westtoestanden' zullen voorkomen. Voor de internationaal opererende bedrijfstakken was het oog gevallen op de kunststofverwerkende bedrijven en op wegtransportondernemingen. Over de mate waarin de activiteiten van de bedrijven uit deze branches als meer of minder conflictrijk getypeerd konden worden bestond aanvankelijk geen zekerheid. Wel was het aannemelijk dat de kleinere aannemersbedrijven en staalconstructiebedrijven zelden over de grens actief zouden zijn. Om meer duidelijkheid te verkrijgen is besloten alle vijf bedrijfstakken in het onderzoek te betrekken.

De verwachtingen ten aanzien van de kenmerken van de bedrijven werden in de interviews niet allemaal bewaarheid. De softwarebedrijven bleken aanzienlijk minder conflictrijk dan was aangenomen. Daarvoor zijn een drietal omstandigheden in hoofdzaak verantwoordelijk. In de eerste plaats bleken de geïnterviewde bedrijven al een aantal jaren (de meeste bedrijven bestonden tussen de 10 en 20 jaar) de strijd om het bestaan te hebben overleefd. Voorts waren de relaties met leveranciers niet erg gevarieerd. Het ging hoofdzakelijk om importeurs of fabrikanten van hardware en randapparatuur, waarmee men meestal vaste en met waarborgen omklede relaties onderhield. Problemen (met name defecten) deden zich wel voor, maar die konden altijd in overleg worden opgelost. Ten slotte waren ook de relaties met de klanten niet erg conflictrijk omdat het overwegend vaste relaties met vaak grotere bedrijven betrof. Bovendien konden zich voordoende problemen vaak direct worden opgelost door de medewerker van het bedrijf die bij de klant was gedetacheerd. De IT-bedrijven bleken bij hun klanten veelal kind aan huis.

De hoofdaannemerij bleek inderdaad een relatief conflictrijke bedrijfstak. De staalconstructeurs bleken in dit opzicht, maar ook in tal van andere opzichten zeer sterke overeenkomsten te vertonen met de aannemers. Uiteindelijk is de keus gevallen op de hoofdaannemers als de conflictrijke pool. Voor de conflictarme pool zijn de kunststofverwerkende bedrijven geselecteerd. Een middenpositie werd ingenomen door het wegtransport. Om de contrasten scherp te houden en het verslag niet al te caleidoscopisch te maken, zijn deze twee andere branches niet in het verslag opgenomen. 
Tabel 1 Geselecteerde Nederlandse ondernemingen naar branche en bedrijfsgroorte

\begin{tabular}{|l|c|c|c|}
\hline & \multicolumn{3}{|c|}{ Branche } \\
\hline Bedrijfsgrootte naar: & $\begin{array}{c}\text { Kunststof } \\
(6)\end{array}$ & $\begin{array}{c}\text { Wegvervoer } \\
(6)\end{array}$ & $\begin{array}{c}\text { Bouw } \\
(6)\end{array}$ \\
\hline Aantal werknemers: & & & \\
\hline Klein <50 & 1 & 3 & 2 \\
\hline Middel $50-250$ & 4 & 2 & 4 \\
\hline Groot $>250$ & 1 & 1 & - \\
\hline Omzet: & & & $(1)^{*}$ \\
\hline Klein <10 mln. & 2 & 3 & 4 \\
Middel $10-40$ mln. & $(2)^{*}$ & 1 & 1 \\
\hline Groot >40 mln. & 2 & & \\
\hline - Schatting betreffende én onderneming. & & & \\
\hline
\end{tabular}

\section{De internationale vergelijking}

\subsection{Vergeleken gebieden}

De keuze van de te vergelijken landen (de Belgische en Duitse regio's aan weerzijden van Nederlands Zuid Limburg) is voor een deel op praktische gronden gedaan. Die hebben te maken met de positie van mijn uitvalsbasis. Andere gronden hebben te maken met de factor 'juridische infrastructuur' die hiervoor aan de orde is gekomen.

Het niveau van het beroep op de civiele rechter van de drie landen wordt doorgaans afgeschilderd als duidelijk verschillend. Nederland staat bekend als 'procesmijdend', wat wil zeggen dat er vergelijkenderwijs weinig civiele procedures worden gevoerd. In Duitsland (dat wil in het vergelijkend onderzoek meestal zeg- 
gen Noordrijn -Westfalen) en België zijn in vergelijking met Nederland de aantallen civiele procedures per 100.000 inwoners beduidend hoger. ${ }^{58}$ Deze verschillen zijn in verband gebracht met institutionele verschillen, met name in kenmerken van de rechtshulpvoorziening, de beschikbaarheid van diverse vormen van buitengerechtelijke geschilbehandeling en gerechtelijke faciliteiten. Zo is in Nederland het aantal advocaten dat per 100.000 inwoners beschikbaar is beduidend kleiner dan in de twee andere landen. Daar staat tegenover dat in Nederland het verlenen van juridisch advies geen monopolie van de advocatuur is, zoals in Duitsland het geval is.

Als een andere belangrijke verklarende factor is gewezen op de omstandigheid dat in Nederland meer dan in de andere landen de mogelijkheid bestaat om buiten het gerecht klachten in behandeling te brengen bij diverse instanties, zoals bijvoorbeeld bij consumenten geschillencommissies, huurcommissies, directeuren voor de arbeidsvoorziening en de Raad van Arbitrage in het bouwbedrijf. Tenslotte zijn er in Nederland weer minder rechters werkzaam per 100.000 inwoners dan in de andere twee landen. ${ }^{59}$ Dit zijn uiteraard hele globale gegevens en het is de vraag of ze ook gelden voor de bedrijven waar het hier om gaat.

\section{Juridisch advies en bijstand}

Wat Nederland betreft zijn enkele gegevens beschikbaar die een beeld kunnen geven van het beroep op advocaten in het bedrijfsleven. Uit onderzoek valt op te maken dat $60 \%$ van de ondervraagde bedrijven zich 'wel eens' voor een zakelijk juridisch advies tot een advocaat had gewend. ${ }^{60}$ Een vrij groot percentage $(40 \%)$ gaf dus te kennen nooit een advocaat te hebben geraadpleegd. Dit totaalcijfer wordt echter in hoge mate bepaald door de kleine bedrijven. Van de bedrijven met meer dan tien werknemers zei meer dan $80 \%$ een advocaat te hebben geraadpleegd, voor de (zeer) kleine bedrijven was dat percentage $58 \%{ }^{61}$

58 Blankenburg en Verwoerd (1989)Prozesehäufigkeiten en Blankenburg (1991) Legal cultures compared en (1994) Tbe infrastructure.

59 O.m. Blankenburg (1991), p. 16 c.v.

60 Van der Veen en Dicke (1990) Fusies in de advocatuur; in het onderzoek waren 236 ondernemingen betrokken.

61 Ibid., p. 10. Grotere bedrijven doen ook met een grotere frequentie een beroep op een advocat dan kleine bedrijven. Van de bedrijven met meer dan 100 werknemers zegt $8 \%$ (binnen een tijdsbestek van 5 jaar) 1 of 2 maal cen advocaat te hebben geraadplecgd, terwijl $64 \%$ dat meer dan 10 maal had gedaan (niet is aangegeven hoeveel meer). Voor de middelgrote en kleine bedrijven lagen de verhoudingen anders: voor de bedrijven met cen aantal werknemers tussen de 10 en 100 lagen de percentages op 23\% (1-2 maal) respectievelijk 39\% (meer dan 10 maal); voor de bedrijven met minder dan 10 werknemers bedroegen de percentages $34 \%$ (1-2 maal) en 36 (meer dan 10 maal). Zo op het oog zijn deze aantallen in het MKB weinig indrukwekkend, zeker binnen een dergelijk 
Is dit een kwestie van beschikbaarheid? Uit een onderzoek naar het inwinnen van zakelijk advies door het midden- en kleinbedrijf (m.k.b.) kwam een andere verklaring naar voren. De advocaat bleek daar een weinig gezochte zakelijk adviseur te zijn. ${ }^{62}$ In het rijtie (binnen een tijdsbestek van 3 jaar) meest geraadpleegde zakelijke adviseurs stond de advocaat (in 1992) op de achtste plaats, achter onder meer de accountant, de verzekeringsadviseur en de boekhouder. ${ }^{63}$ Men bleek in het m.k.b. als zakelijk adviseur de accountant te prefereren boven de advocaat:

"Er is een sterke neiging van de advocaat weg te denken. Dit 'advocaatvermijdingsgedrag' houdt onder meer verband met de voorkeur in dit milieu van ondernemers voor het soepel oplossen van conflicten" en "Essentieel is het probleem dat de advocaat geassocieerd wordt met het conflict, terwijl in dit milieu conflictvermijding voorop staat ${ }^{\text {" }}$ -

Deze associatie bleek ook in daden bevestigd te worden. Meestal werd een advocaat ingeschakeld in verband met 'een zaak', waarbij de aanvrager dat ook nog voornamelijk deed in de hoedanigheid van 'gedaagde', ${ }^{65}$

Iets dergelijks komt naar voren uit onderzoek naar de juridische dienstverlening in België bij kleine en middelgrote ondernemingen (k.m.o.'s). ${ }^{66}$ Ook daar bleek de advocaat slechts één van de vele juridische dienstverleners. En ook hier is de tendens duidelijk:

"Het hoofdaccent van de advocaat ligt dus voor vele ondernemingen nog steeds op bet oplossen van geschillen in de curatieve sfeer. $" O$

De andere juridische dienstverleners werden in hoofdzaak voor juridisch advies geraadpleegd.

Uit onderzoek in Duitsland bleek de advocaat minder grote en diverse concurrentie te hebben: het waren vooral vakorganisaties, accountants en belastingdeskundigen die - buiten de advocaat - om advies werden gevraagd. ${ }^{68}$ Maar ook hier lag onmiskenbaar het accent minder op advies dan op geschilbehandeling. ${ }^{69}$ Ook hier werd een verband gelegd met het imago van de advocaat:

tijdsbestek.

62 ISK-rapporten van de NOvA (1987) en (1992) De advocaat en het MKB; de gegevens hadden betrekking op 252 (1987) resp. 101 (1992) ondernemingen.

63 Ibid. (1992) p. 7.

64 lbid. (1987) p. 1 en 5.

65 Ibid. (1992) p. 24-25.

66 Van Houtte, Thielman en De Valck (1996) De zakenwereld en de juridische dienstverlening de gegevens hadden betrekking op ruim 1100 bedrijven.

67 Ibid., p. 27

68 Wettmann en Jungjohann (1989) Inanspruchnahme anvaltlicher Leistungen, p. 61; in dit onderzoek werden 186 ondernemers betrokken.

69 Ibid., p. 242-242. 
"Die enge Assoziation von Anwalt und Prozesz bzw. die Tatsache, dasz der Anwalt weithin als "Drohgebärde" empfunden wird, begrenzt in starken Masze die Inanspruchnahme anwaltlicher Beratung im bereich geschäftlicher Beziehungen." Blijkens deze onderzoeken is de huiver onder ondernemers om voor juridisch advies een advocaat in te schakelen een internationaal verschijnsel. Anderen hebben daarbij de voorkeur, in ieder geval in Nederland en België. De Duitse advocaat lijkt tegenover zijn concurrenten iets sterker te staan. Als er evenwel een geschil is ontstaan geldt de advocaat in de drie landen als de meest aangewezen deskundige voor bijstand. Als het zover komt is de advocatendichtheid in België en Duitsland groter dan in Nederland maar daarmee is niet gezegd dat Nederlandse bedrijven moeite hebben met het doen van een beroep op hun diensten.

\section{De kanalisering van geschillen}

Niet in discussie is hier de stelling dat de infrastructuur van instanties die beschikbaar is voor geschilbehandeling invloed zal hebben op de keuzes die gemaakt worden voor het doen van gerechtelijke of andere stappen inzake gerezen geschillen. Voor het onderhavige onderzoek is ten minste één punt van verschil tussen de drie landien van beteḱenis.

Dit verschil is dat er in Nederland voor geschillen over bouwwerken een veel gebruikte arbitrageprocedure bij de Raad van Arbitrage voor het Bouwbedrijf bestaat, een voorziening die in België en Duitsland tot dusverre geen rol van betekenis heeft gespeeld. In de Nederlandse bouwnijverheid is een arbitragebeding gebruikelijk waarbij partijen overeenkomen dat in het geval zich een geschil voordoet, ze "afstand doen van hun recht de tussenkomst van de gewone rechter in te roepen". ${ }^{71}$ Het geschil wordt in arbitrage vooral beoordeeld door deskundige arbiters, i.c. bouwkundigen. ${ }^{72}$ Zaken waarin het betwiste belang de fl. 65.000 (en sinds $1998 \mathrm{de}$ fl. 100.000) niet overschrijden worden door één arbiter behandeld; boven dat bedrag bestaat de arbitragecommissie uit 3 arbiters. ${ }^{73}$ De arbitragekosten bedragen in ruim de helft van de zaken niet meer dan fl. 6000 en betrekkelijk zelden (ongeveer $20 \%$ vàn de zaken) meer dan fl. 10.000 . Het arbitrale vonnis kan middels een verlof van de bevoegde rechtsbankpresident (art. $1062 \mathrm{Rv}$.) eventueel een executoriale titel opleveren.

70 Ibid., p. 43.

71 Cf. par. 49 van de Uniforme Administratieve Voorwarden, in: SDU(1990) Bundel neonchriften, p. 230.

72 Het Wetboek van Burgerijike Rechtsvordering bevat (in boek vier) algemene regels betreffende arbitrage. (artt. 1020-1076 Rv.). Deze regels betreffen onder meer de benoeming van de arbiters, het voeren van het arbitraal geding en het arbitraal vonnis.

73 Raad van Arbitrage voor de Bouwbedrijpen in Nederland (2000) Jaarverslag. 1999, p. 3. 
De Raad heeft de afgelopen jaren tegen de duizend geschillen per jaar ter behandeling ontvangen. ${ }^{78}$ Vermeldenswaard is dat in de periode $1995-1999$ per jaar ongeveer een derde van de afgewikkelde zaken blijken (voor de arbitrale uitspraak) te zijn ingetrokken en ongeveer een kwart van de uitspraken betreft een schikking; ongeveer de helft van de afgewikkelde zaken is derhalve ingetrokken of bij vonnis geschikt.

Een ander verschil is het feit dat er in Nederland geen afzonderlijke rechterlijke instantie is voor handelsgeschillen, zoals in België en Duitsland. In deze 'rechtbanken van koophandel' en 'Handelsgerichte' hebben naast beroepsrechters ook lekenrechters zitting die als koopman te boek staan en uit dien hoofde als inhoudsdeskundig gelden. ${ }^{76}$ In beginsel behandelen deze gerechten geschillen tussen 'kooplieden' waarbij moet worden aangetekend dat ook vennootschappen als zodanig plegen te worden beschouwd.

\section{Kostendrempels}

Volgens Blankenburg zijn de rechtsprekende instanties in Duitsland: "too efficient and inexpensive to create incentives for plaintives to avoid them." 77 Op het punt van ak rfnanciélie k'osten van procedüres is tiet moeilijk een algemeen beeld' te schetsen omdat ze uit verschillende componenten zijn opgebouwd en sterk variëren met de kenmerken van het geschil in kwestie. Wel valt er iets te zeggen over de 'efficiëntie' - voor zover daarmee de doorloopsnelheid bedoeld wordt - van de procedures die hier van belang zijn. Als we ons concentreren op het niveau van de rechtbanken (in eerste aanleg) dan blijken de Landgerichte in Noordrijn-Westfalen inderdaad zaken relatief het snelst af te wikkelen. In 1995 was de gemiddelde doorloopsnelheid van civiele zaken 6,7 maanden. ${ }^{78}$ Afzonderlijke cijfers voor de Handelsgerichte werden niet vermeld. Voor de Nederlandse Arrondissementsrechtbanken is voor 1995 een gemiddelde doorloopsnelheid van contradictoire zaken berekend van 17 maanden ofwel 1,4 jaar. ${ }^{79}$ De doorloopsnelheid van zaken die zijn aangebracht bij de Belgische Rechtbanken in eerste aan-

74 De absolute aantallen zijn 866 (1995), 848 (1996), 914 (1997), 951 (1998), 956 (1999); ibid., p. 2.

75 Ibid. p. 3.

76 De bevoegdheid en samenstelling van de Duitse 'Kammern für Handelssachen' is geregeld in par. 95 e.v. Gerichtsverfassungsgesetz; op de Belgische 'Rechrbanken van Koophandel' zijn de artt. 84-85 en 573-576 Gerechtelijk Wetboek van toepassing; zie voorts Pottschmidt en Rohr (1990) Privatrecht für den Kaufman en Van den Bergh en Dirix (1992) Handels-en economisch recht.

77 Blankenburg (1994) The infrastructure, p. 806.

78 Deze gegevens zijn te vinden op de site van het Ministerie van Justitie van Noordrijn-Westfalen: www.jm.nrw.de

79 Zie Klijn (1999) Over(-)tijdige gerechtelijke afdoening, p. 105. 
leg wordt aangegeven in jaren: voor 1995 wordt 2,84 jaren opgegeven. ${ }^{80}$ Voor de Rechtbanken van Koophandel wordt voor hetzelfde jaar een doorloopsnelheid opgegeven van 3,18 jaar. Er moet bij dergelijke cijfers wel bedacht worden dat de doorloopsnelheid per gerecht aanzienlijk kan verschillen.

Gezien het feit dat er in Duitsland en België vrij veel in hoger beroep wordt gegaan, is ook de doorloopsnelheid van de beroepsinstanties van belang. Voor de Oberlandesgerichte van Noordrijn-Westfalen wordt voor 1995 een gemiddelde doorloopsnelheid opgegeven van 8,7 maanden. Voor de Belgische Hoven van Beroep is voor 1995 een (theoretische) doorloopsnelheid berekend van 5,16 jaar.

Op papier lijkt het er op dat de drempels voor het doen van gerechtelijke stappen in Noordrijn-Westfalen lager zijn dan in België. Nederland neemt wat dit betreft een tussenpositie in, met dien verstande dat in bouwgeschillen buitengerechtelijke arbitrage een (gebruikelijke) optie is.

\subsection{Branches}

Voor de internationale vergelijking was het de bedoeling die te beperken tot de branches die in Nederland het meest bleken te contrasteren, zowel wat betreft de frequentie waarmee zich klachten en geschillen voordoen als wat betreft internationale oriěntatie. Het lag na de analyse van het Nederlandse materiaal voor de hand de keuze te laten vallen op de kunststofverwerkende industrie en de aannemers in de bouwnijverheid. Tabel 2 geeft een beeld van de bedrijfsgrootte van de ondernemingen per branche en per land.

\section{Materiaalverzameling en -verwerking}

De adressen van bedrijven zijn verkregen via de Kamers van Koophandel in de verschillende regio's of via hun private opvolgers. Het verkrijgen van toestemming voor een interview was een heel karwei. De ondernemers hadden uiteraard dringender zaken te doen. De moeite die het kostte om toestemming te verkrijgen leek per branche en per land te variëren. In Nederland waren de aannemers het minst toeschietelijk, gevolgd door de wegtransporteurs. In Duitsland waren de aannemers ronduit weigerachtig, maar in België gingen zij betrekkelijk gemakkelijk op een zelfinvitatic in. In België waren de ondernemers uit de kunststofver-

80 Demuylder c.a. (1999) De gerechtelijke achtentand in Belgie, p. 28. Het betreft hier wel een theoretische behandelingsduur: het gaat om het aantal niet-afgehandelde zaken aan het eind van het jaar gedeeld door het aantal gedurende het jaar afgedane zaken. 
werkende industrie moeilijk bereikbaar, door reislustigheid en de effectieve barrières die hun secretariële hulp wisten op te werpen. In Duitsland was ook deze bedrijfstak moeilijk te benaderen voor een interview. De gesprekken in Nederland en België verliepen doorgaans in een goede sfeer, al waren sommige respondenten merkbaar op hun hoede. In Duitsland maakten de zegslieden van de onderneming het meest de indruk op hun hoede en terughoudend te zijn.

Tabel 2 Geselecteerde Belgische en Duitse ondernemingen naar branche en bedrijfsgrootte

\begin{tabular}{|c|c|c|c|c|}
\hline \multirow[b]{2}{*}{ Branche } & \multicolumn{2}{|c|}{ België } & \multicolumn{2}{|c|}{ Duitsland } \\
\hline & $\begin{array}{c}\text { Kunststof } \\
\text { (5) }\end{array}$ & $\begin{array}{c}\text { Bouw } \\
\text { (5) }\end{array}$ & $\begin{array}{l}\text { Kunststof } \\
\text { (5) }\end{array}$ & $\begin{array}{c}\text { Bouw } \\
\text { (5) }\end{array}$ \\
\hline \multicolumn{5}{|l|}{ Bedrijfsgrootte naar: } \\
\hline \multicolumn{5}{|l|}{ Aantal werknemers: } \\
\hline Klein $<50$ & 2 & 1 & 1 & 1 \\
\hline Middel 50-250 & 2 & 4 & 4 & 3 \\
\hline Groot $>250$ & 1 & - & - & 1 \\
\hline \multicolumn{5}{|l|}{ Omzet: } \\
\hline Klein $<10 \mathrm{mln}$. & - & - & 1 & 1 \\
\hline Middel $10-40 \mathrm{mln}$. & 2 & 3 & 2 & 2 \\
\hline Groot $>40 \mathrm{mln}$. & 3 & 2 & 2 & 2 \\
\hline
\end{tabular}

De interviews in Nederland zijn gevoerd in de loop van 1995 en 1996. De Duitse en Belgische interviews zijn afgenomen in de loop van 1997 en 1998. Uiteindelijk is in Nederlands Limburg bij zes ondernemingen per branche een interview afgenomen. Het grootste bedrijf, een kunststofverwerkend bedrijf, was recentelijk zeer snel gegroeid van de driehonderd personeelsleden die in de gegevens van de Kamer van Koophandel stonden genoteerd naar vijfhonderd. Niette$\mathrm{min}$ is het daarmee nog een relatief klein bedrijf wanneer we het vergelijken met het personeelsbestand van een echt groot bedrijf. Zo telde bijvoorbeeld DSM (weliswaar geen kunststofverwerker maar - onder meer - een kunststofproducent) in 1996 een aantal van ruim 18000 werknemers in het jaarverslag. Ook onder de bouwondernemingen zijn er veel grotere bedrijven. Ballast Nedam gaf in het jaarverslag van 1996 een personeelsbestand op van ruim 8000. En de eveneens beurs- 
genoteerde wegtransporteur Frans Maas gaf in hetzelfde jaar een aantal van bijna 4000 werknemers op.

De interviews zijn met een taperecorder opgenomen en uitgewerkt. Op basis van deze verslagen is het onderzoeksverslag gemaakt. Daarbij is in grote trekken de structuur van de interviewagenda gevolgd. 


\section{HOOFDSTUK 4}

\section{De logica van het ondernemen}

Wanneer ik mijn respondenten voor een interview trachtte te winnen en uitlegde waar het om ging, kreeg ik regelmatig, op de cue 'juridisch', als reactie de mededeling dat ik aan het verkeerde adres was, want: "zoiets komt bij ons zelden voor!" Uit de interviews bleek daar waarheid in te schuilen, maar niet voor alle bedrijfstakken in dezelfde mate. Sommige bedrijfstakken bleken vrij duidelijke contrasten te vertonen in de mate waarmee zich klachten en geschillen in de relaties met leveranciers en klanten voordeden. Dat is ook het criterium waarmee de volgende paragrafen zijn gerangschikt. De kunststofverwerking is, waar het de bedoelde relaties betreft relatief vrij van fricties. In de bouwnijverheid treden ze daarentegen regelmatig op. Het wegtransport neemt in dit opzicht een tussenpositie in.

\section{Kunststofverwerking: dominante partners}

De kunststofverwerking opereert in de slagschaduw van de grote industric. De kunststofverwerkende industrie is voor een belangrijk deel een internationaal georiënteerde bedrijfstak, zowel wat de inkoop van grondstoffen als de verkoop van producten betreft. De branche is internationaal actief en enkele bedrijven vormen duidelijk een onderdeel van de wereldomspannende industriële netwerken (waarbij de wereld dan vooral bestaat uit: de Verenigde Staten, Europa en Azië). De internationale relaties komen tot uitdrukking in de spreiding van vestigingen en de relaties met moederbedrijven. Verschillende bedrijven in deze branche bleken productiebedrijven te zijn. Dat wil zeggen dat er dag en nacht geproduceerd en dus gewerkt wordt. De onderneming koopt grondstoffen, bewerkt ze in de eigen fabriek en verkoopt de aldus vervaardigde halffabrikaten, onderdelen en in sommige gevallen eindproducten. Twee bedrijven bewerkten kunststof ook 'in opdracht': de klant levert dan zelf de te verwerken grondstof aan en neemt ze na bewerking weer af. 
Van de benaderde bedrijven zijn er vier middelgroot (rond de 100 medewerkers). Eén bedrijf bleek in korte tijd sterk gegroeid tot een grote onderneming ( 500 medewerkers). Vijf bedrijven vertoonden, ondanks alle verschillen, toch een duidelijke verwantschap in de manier van werken en zaken doen. Eén bedrijf (Summer) week van dit patroon af. ${ }^{1}$ Daarvan zal apart verslag worden gedaan. Het volgende verslag is vooral gebaseerd op de gegevens die van de overige vijf bedrijven zijn verkregen.

\subsection{Leveranciers}

De belangrijkste leveranciers in deze branche zijn leveranciers van grondstoffen. Het zijn veelal grote chemische concerns, waarbij grote hoeveelheden chemische (bulk-)producten worden afgenomen. In de relaties met deze leveranciers (evenals trouwens in die met klanten) doen zich vrijwel nooit problemen voor die uitmonden in het ondernemen van gerechtelijke stappen. In de afgelopen drie jaar is dat bij deze bedrijven niet voorgekomen. Dat wil natuurlijk niet zeggen dat altijd alles geheel volgens verwachting gaat. Er doen zich in de relatie met leveranciers met een zekere regelmaat 'problemen' voor, voornamelijk met betrekking tot de kwaliteit van het geleverde product. Op het vlak van de levertijden is de logistiek blijkbaar dermate gevorderd dat zich daarbij vrijwel nooit problemen voordoen. Rubber heeft bijvoorbeeld een 'leveringsbeoordelingssysteem' dat aantoont dat de leveranciers vrijwel $100 \%$ betrouwbaar zijn wat betreft de nakoming van de levertijd.

Gebreken in de leveranties van grondstoffen komen doorgaans aan het licht bij de 'ingangscontrole' middels analyse van een monster in het eigen laboratorium of anders middels handmatige controle, op het moment dat het bestelde product bij de fabriek wordt afgeleverd. Soms komt het gebrek pas aan het licht wanneer de klant (de uiteindelijke afnemer van het door de fabriek verwerkte product) erover reclameert. Het probleem is dan meestal dat een hele leverantie (of een significant gedeelte ervan) niet aan de afgesproken specificaties blijkt te voldoen.

Aan dergelijke 'problemen' blijkt men evenwel niet zo zwaar te tillen. $\mathrm{Er}$ wordt in ieder geval enigszins luchthartig over gesproken. Dat komt deels omdat dergelijke problemen relatief zelden voorkomen en deels omdat ze volgens een bepaalde min of meer vaste routine met de leverancier worden opgelost. In die zin zijn dergelijke storingen geen problematische storingen, dat wil zeggen zaken waaraan veel tijd en inspanning hoeft te worden besteed. Deze houding maskeert

I Een kort profiel van de bedrijven is te vinden aan het einde van dit hoofdstuk. 
evenwel dat deze stand van zaken veelal het resultaat is van aanzienlijke inspanningen die verschillende betrokkenen (de leverancier, de afnemer en soms ook de klant van de afnemer) zich getroosten om de kans op problemen zoveel mogelijk te reduceren of anders gezegd: om zoveel mogelijk te garanderen dat de gewenste kwaliteit wordt geleverd.

\section{Het reduceren van de kans op problemen}

Wat doet men dan om de kans op kwaliteitsproblemen te verkleinen?

\section{A) Contracten}

De leverantie van grondstoffen wordt juridisch vormgegeven door middel van een combinatie van 'raamcontracten' en orders. In deze raamcontracten worden principe-afspraken gemaakt over op afroep te leveren grondstoffen. Deze contracten bevatten naar men zegt hoofdzakelijk (1) zo gedetailleerd mogelijke technische specificaties van de te leveren grondstof, (2) prijsafspraken die gekoppeld zijn aan de afgenomen hoeveelheid en (3) leverings- en betalingsvoorwaarden. Men legt zich bij deze raamafspraken niet vast op een bepaalde afname van grondstoffen. Dat gebeurt middels de orders van het bedrijf aan de leverancier onder verwijzing naar het raamcontract. De raamcontracten leiden dus pas tot feitelijke leveranties als er door het bedrijf orders worden verstuurd naar de leverancier en pas dan wordt er (per order) gefactureerd. De te leveren grondstof wordt in het raamcontract zover mogelijk technisch gespecificeerd. Bij veel chemische producten kan dat zeer precies. $\mathrm{Bij}$ andere producten echter, zoals bijvoorbeeld rubber, moet soms worden volstaan met het aangeven van kwaliteitsmarges. Rubber wordt in grote hoeveelheden ('batches') tegelijk aangemaakt en heeft nooit helemaal precies dezelfde kwaliteit. Wanneer deze afwijkingen binnen bepaalde marges blijven is er geen probleem. In het eigen productieproces worden die marges dan verkleind tot de eisen die de klanten stellen. De zegsman van Folie geeft aan dat contractuele specificaties in de loop der tijd steeds preciezer worden:

"Dat is een proces dat loopt al vijfien jaar tussen Folie Europe en die spelers, dat is helemaal uitgekristalliseerd, iedereen weet precies waar hij aan toe is en...er ontstaan geen problemen. Dat is zo degelijk geregeld dat zelfs de losslang, die op die truck zit, daarvan is gespecificeerd: wat moet dat voor materiaal zijn, hoe schoon moet die zijn, hoe schoon moet de truck zijn, de truck moet gewassen zijn. "(Folie) Contractuele afspraken vormen een belangrijke, maar niet de enige factor die van belang is voor de reductie van de kans op kwaliteitsproblemen. Een andere factor van belang is het feit dat (zoals de man van Folie ook al aangeeft) vaak een beperkt aantal vaste leveranciers van grondstoffen is geselecteerd. 


\section{B) Vaste leveranciers}

De keuze van vaste, naar eigen ervaring betrouwbaar gebleken, relaties kan in beginsel het effect hebben dat de kans op problemen wordt gereduceerd. Maar dat wil niet zeggen dat de selectie van vaste relaties met bepaalde leveranciers door een bedrijf alleen wordt gedaan vanuit dit oogmerk. De keuze van vaste leveranciers is zelfs niet altijd een keuze van het bedrijf zelf. Er zijn meer factoren die de selectie van vaste leveranciers bevorderen. Er zijn soms bedrijfseconomische motieven in het spel:

"... we kunnen niet zeggen van we hebben een bepaalde kwaliteit rubber en we kopen hem vandaag bij [chemisch bedrijf $X$ ] en morgen bij [chemisch bedriif $Y$ ], want die is drie centen goedkoper en daarna gaan we weer voor 6 centen goedkoper daarheen, nee. Dat kan je niet doen, want dan moet je elke keer weer je recepturen in je fabriek, je fabricagemethoden in je fabriek gaan veranderen. Want, ik zei $U$ al, batches zijn niet vergelijkbaar van éen leverancier, maar als je dan een batch krijgt ook nog van een andere leverancier... dan moet je alles weer gaan aanpassen." (Rubber)

Bovendien kan prijs gerelateerd zijn aan kwaliteit waardoor het op zoek gaan naar koopjes, als een bepaalde kwaliteit wordt vereist, weinig zin heeft. De keuze van een vaste leverancier is dan vooral een kwestie van efficiency.

Het opteren voor vaste leveranciers kan voorts een eis van de klant zijn. Klanten laten soms in het raamcontract vastleggen van welke grondstoffenproducent een bepaalde grondstof of onderdeel in het product moet worden verwerkt. De reden daarvoor is dat ze absoluut zeker willen zijn van de kwaliteit van de onderdelen van hun product. Enkele grote klanten van Rubber stellen stringente eisen op dit vlak:

Interviewer (I): Je mag niet shoppen?

Respondent (R): Nee, die willen weten wanneer je wijzigt van leverancier van grondstoffen. $U$ moet zich voorstellen: $x$-miljoen van die rollen maken wij wereldwijd voor [kantoormachinefabrikant]. We hebben het een aantal jaren geleden meegemaakt, dat is nog niet zo heel eng lang geleden, dat onze fabriek in Amerika aan het shoppen ging zonder dat iemand het wist. Die hakten nog niet zolang met dat bijlije en die gingen aan het shoppen en een half jaar later werd het afgekeurd. En toen konden ze bijna cen miljoen printers terugnemen uit de markt. Weet $U$ wat dat betekent?

I: Jaja.

$R: J a$, dat kan niet. Nee, dat moet je absoluut niet doen. De kwaliteiten die wij kveren die zijn gekeurd, die zijn getest, die zijn goedgekeurd. Het duurt lang voordat je een goedkeuring krijgt, hoor.

I: Een goedkeuring van wie?

$R$ : Van onze klant, van [kantoormachinefabrikant]. Wij sturen op en zij doen daar sesten mee, fieldrests, die worden heel uitgebreid getest, die zaken. En op een 
gegeven moment zeggen zij: dit is de kwaliseit die wij wensen en dan moet je wel zorgen dat je die kwaliteit levert. (Rubber)

Uiteindelijk is de keuze van een vaste leverancier ook hier ingegeven door angst voor kwaliteitsproblemen, maar in dit geval ligt de bezorgdheid van de klant van het bedrijf ten grondslag aan die keuze en niet in de eerste plaats die van het bedrijf zelf. Dergelijke arrangementen kunnen blijkbaar uitvloeisel zijn van pijnlijke ervaringen in het verleden.

Soms gaat de klant nog een stapje verder in de bemoeienis met de leverancier:

$R$ : "[elektrische apparatenfabrikant] doet dat bijvoorbeeld. [Die] is zelf heel erg deskundig op het gebied van kunststoffen, die hebben zelf spuitstof-fabrieken en die schrijven je gewoon voor die en die grondstof te gebruiken en speciale kleuren, die ze dan bij [chemieconcern X en Z] in hele grote massa's laten aanmaken - want wij zijn éen van de leveranciers van [dit bedrijf] - maar ze hebben bepaalde eigen [bedrijf]-kleuren en ze laten die kleuren aanmaken bij [chemieconcern Z] 100 ton en dan zeggen ze dan moet je 20 ton aan Rubber leveren en 20 ton aan die leveren en 10 ton aan die en 5 ton aan die. Dus daar heb je eigenlijk helemaal niks over te vertellen. "(Rubber)

Een enigszins verwante gang van zaken is aangetroffen bij Korrel. Deze firma maakt kunststoffen halffabrikaten, die vooral gebruikt worden bij de vervaardiging van kunststofonderdelen in de auto-industrie. Ruim de helft van de omzet van het bedrijf is wat genoemd wordt 'derden'-omzet, dat wil zeggen dat de klant zelf de grondstof aanlevert en het product na bewerking door Korrel weer afneemt. De klant is in dat geval zelf verantwoordelijk voor de aangeleverde kwaliteit. Voor dit deel heeft het bedrijf dus eigenlijk geen grondstofleveranciers. Het is dan meer een dienstverlenend bedrijf. De firma Pellet is net als Korrel een bewerker van kunststoffen tot halffabrikaten en werkt zelfs helemaal in opdracht ("loonbemaling').

Resultaat van dergelijke arrangementen is dat de kans op klachten over de kwaliteit van het product sterk wordt gereduceerd: alles is erop afgestemd om te garanderen dat de klant precies de kwaliteit krijgt die hij verlangt. Sommige klanten blijken geneigd daarbij weinig aan het toeval (zoals de beslissingen van hun toeleveranciers) over te laten.

Tenslotte wordt de keuze van bepaalde vaste leveranciers bij sommige bedrijven gedaan door (een onderdeel van) het moederbedrijf. Zo stelt bijvoorbeeld het Europees hoofdkantoor van de foliepoot van het petrochemische concern waartoe Folie behoort de raamcontracten op met een vijftal door haar geselecteerde grondstoffenleveranciers, op basis waarvan Folie vervolgens naar behoefte bij deze leveranciers orders kan plaatsen. Een reden voor deze bemoeienis is dat Folie slechts één van de productiefaciliteiten is in Europa waarvan de producten identiek moeten zijn. De distributie van de producten staat namelijk onder regie van een centraal distributiecentrum en het is mogelijk dat een klant een levering krijgt 
die is samengesteld uit producten van verschillende fabrieken. De klant mag dat niet merken want die heeft een nauwkeurig gespecificeerd product besteld bij het moederbedrijf. Daarnaast zijn er natuurlijk schaalvoordelen verbonden aan gemeenschappelijke raamcontracten ("wij zijn de grootste polypropeen-koper in Euro$p a$, dus het heeft zin dat centraal te doen"). Bovendien geeft deze opzet enige flexibiliteit bij het opvangen van productiestoringen in een van de fabrieken. Ook bij Korrel loopt een deel van de inkoop van grondstoffen bij een vijftal grote ondernemingen over de band van zijn Aziatische moeders. Deze concerns regisseren de inkoop en levering van een deel van de grondstoffen die Korrel bewerkt. Dat doen ze in het kader van hun vaste relaties met grote autofabrieken. De bewerkte kunststof heeft dan ook meestal een van de vestigingen van deze concerns als afnemer. De onderneming is overigens niet uitsluitend een productiefaciliteit want men werkt ook voor eigen rekening voor zelf aangeworven opdrachtgevers.

In een enkel geval is de toeleverancier een onderdeel van het eigen bedrijf. Zo koopt Rubber metalen onderdelen voornamelijk in bij een Zwitserse zusteronderneming.

\section{C) Kwaliteitszorg}

In de chemische industrie lijkt 'kwaliteitszorg' een vanzelfsprekendheid geworden. De werkwijze, die zo wordt genoemd, beoogt een productie van constante door de klant gewenste kwaliteit te waarborgen en wordt gezien als een garantic voor een goede interne organisatie van het bedrijf. De meeste kunststofverwerkende bedrijven bleken zelf ook een kwaliteitssysteem te hebben geïnstalleerd en ten bewijze daarvan een 'ISO-certificaat' te hebben verworven van een organisatie die dergelijke systemen toetst (en na de verkrijging van het certificaat regelmatig controleert). In paragraaf 4.1 zal verder uit de doeken worden gedaan wat dit allemaal om het lijf heeft. Het gaat kort gezegd om stelselmatig 'monitoren' van alle onderdelen van het productieproces, met de bedoeling van voorgekomen fouten te leren, zodat ze in het vervolg kunnen worden voorkomen. Een typisch 'reflexieve' werkwijze volgens de omschrijving van Giddens.

$\mathrm{Bij}$ het merendeel van de bedrijven maakt men geen gewag van het belang van het kwaliteitssysteem voor het reduceren van de kans op problemen in de relatie met de leveranciers. Alleen bij Compound voert men het feit, dat alleen zaken worden gedaan met 'ISO-gecertificeerde' bedrijven, uitdrukkelijk aan als verklaring voor het zelden voorkomen van problemen in de relatie met toeleveranciers. Eén van de onderdelen van het meestal gebruikte kwaliteitssysteem (ISO-9000 genaamd) bestaat uit het installeren en bijhouden van procedures voor "het evalu- 
eren en selecteren [van toeleveranciers] op basis van hun vermogen om te voldoen an de eisen van het toeleveringscontract". 2 De gecertificeerde bedrijven zullen derhalve wel in enigerlei vorm de betrouwbaarheid van hun toeleveranciers evalueren. Maar bij de selectie van de toeleveranciers lijkt het hebben van een ISO-certificaat voor het merendeel van de bedrijven van ondergeschikt belang (voor zover men er al iets over te zeggen heeft), bijvoorbeeld omdat het (naar sommige zegslieden zeggen) slechts in beperkte mate selecteert (de meeste toeleveranciers zijn ISO-gecertificeerd) en omdat men vooral ook op eigen ervaringen afgaat. De ISO-procedures zijn van veel groter belang voor de preventie van problemen in de relatie met klanten, zoals nog zal blijken.

\section{De behandeling van problemen}

Al deze voorzorgsmaatregelen kunnen niet voorkomen dat er zo nu en dan toch iets fout gaat. Dat wordt gezien als een onvermijdelijk en ook wel begrijpelijk gegeven. In ieder geval wordt er rekening mee gehouden dat er iets mis kan zijn met een leverantie.

Toegeleverde goederen worden (overigens ook in overeenstemming met de geldende ISO-normen voor kwaliteitsmanagement) veelal aan een 'ingangscontrole' onderworpen, waarbij een monster in het laboratorium wordt geanalyseerd of een steekproef uit een levering anderszins wordt gecontroleerd op het voldoen aan de gestelde specificatie. Als er fouten worden geconstateerd handelt men die volgens een bepaalde routine af. Meestal stuurt men de lading retour afzender en ontvangt een nieuwe. Bij bulkladingen kunststof kan dat moeilijk anders.

"Wat wij doen is dat van iedere truck een monster wordt getrokken. Als er twijfels zijn dan wordt er even door een of twee mensen naar gekeken en als er echte twijfels zijn dan gaat hij gewoon terug. Daar is eigenlijk nooit een discussie over, dan komt er een andere. Je praat dan over denk $i k$, misschien 0,1 of 0,2 procent van die totale leveranties. En die gaan gewoon terug en die worden vervangen en daar wordt verder niet meer over [gesproken]. Ja er wordt misschien nog eens over gepraat wat is er gebeurd... [...]

Klachten worden snel geregeld. Er zitten open lijnen ook op het kwaliteitsgebied tussen de 'plants' en die leverancier, waar technische mensen en logistieke mensen met elkaar in overleg gaan. Het kan variëren van dat er eens een lading spinnen in een truck zat, waar een van de mensen hier een van die spinnen in een doosje deed en in een enveloppe naar die mevrouw aan de andere kant stuurde en die sprong zo hoog! Maar dat heeft veel meer effect dan moeilijk met elkaar te gaan praten en te 
gaan corresponderen. Dan lach je daar een keer met elkaar over en dan wordt dat gewoon opgelost." (Folie)

Bij Rubber komen problemen met levering van rubber en kunststof vrijwel nooit voor. De geleverde kunststof en rubber levert nooit problemen op, omdat altijd binnen de kwaliteitsmarges wordt geleverd en de grondstof (zoals hierboven al is aangegeven) middels receptuur van het eigen laboratorium wordt aangepast.

"Eigenlijk hebben we daar nooit last mee gehad. Er is wel eens een zak kunststof die te nat is, er is wel eens een zak opengescheurd of iets dergelijks.. nou dan bellen we op en dan zeggen we er is een zak kapot, nou dat is helemaal geen probleem hoor, dan krijgen we de volgende keer een zak extra, daar doen ze echt niet moeilijk over. Nee daar hebben we eigenlijk eh. Ja in het verleden [ 8 jaar geleden] wel, we hebben een keer in Oost-Duitsland een ramsjpartij gekocht, man dat was verschrikkelijk, daar zat meer regenwater in dan rubber...ja en dan gaat gewoon die hele vrachtwagen terug." (Rubber)

Ook bij de andere bedrijven worden gebrekkige leveranties teruggestuurd en vervangen. En wanneer het slechts om een deel van de levering gaat wordt het gebrekkige deel door de leverancier gecompenseerd door een creditnota (Compound). Deze procedure wordt ook gevolgd door Rubber wanneer het gaat om metalen onderdelen:

"... we hebben hier een ingangscontrole, en als die op een gegeven moment fouten constateert, dan gaat het via de afdeling inkoop en die neemt dan contact op met de leverancier, en omdat het meestal onderdelen zijn die wij dringend nodig hebben; we hebben liefst niet zoveel voorraden. Ik moet zeggen, dat gaat eigenlijk vrij prettig met onze leveranciers. We maken gewoon afspraken: weet je wat, of we sorteren gewoon hier intern uit, dat gebeurt vaak... of we sturen zaken terug, dan zeggen ze: jongens stuur maar terug dan krijg je morgen een nieuve partij...als er voorraad is... en als het niet op voorraad is, en dat zijn ze nogal eens, nou dan sorteren we het zelf uit, sturen de fouten naar de [leverancier] en krijgen we keurig een creditnota, eigenlijk bebben we daar eigenlijk niet zo verschrikkelijk veel problemen mee." (Rubber)

Korrel werkt zoals gezegd veel met kwaliteitsgaranties van opdrachtgevers. Kwaliteitsproblemen met leveranties waarvoor geen garantie is gegeven komen aan het licht bij een ingangscontrole. Gebleken fouten worden afgehandeld zoals hiervoor beschreven. Bij de grondstoffen die met een kwaliteitsgarantie worden aangeleverd gaat het anders. Dan vindt de controle pas plaats, na de bewerking van de grondstof, op het 'gereed product'. Dit houdt verband met het feit dat de toeleverancier zich garant heeft gesteld voor de kwaliteit van de grondstof:

"Je hebt integrale kwaliteitszorg onder ISO, wij zijn ISO 9002 gecertificeerd, en daarbinnen is eigenlijk een belangrijke voorwaarde bij bet inkopen van grondstoffen, dat van elke grondstof die binnenkomt: of is vastgesteld dat hij aan de juiste specificaties voldoet, of dat er een verklaring is van de leverancier is, dat het die en 
die grondstoffen zijn met die en die specificaties. In het laatste geval worden die grondstoffen ontvangen en die worden dan patsboem in de productie gebruikt." (Korrel)

Dan kan het zijn dat tijdens het productieproces uit een test of naar aanleiding van een klacht van de uiteindelijke afnemer blijkt dat het gereed product niet aan de specificaties voldoet. Dan wordt nagegaan of de fout tijdens het productieproces is gemaakt of dat de oorzaak bij de grondstof ligt. In het laatste geval zal de toeleverancier de grondstof moeten aanvullen of vervangen en moeten opdraaien voor de eventuele schade die de klanten of derden hebben geleden. Ook bij Pellet gaat men op die basis te werk.

Als blijkt dat de door de klant ter veredeling aangeleverde kunststoffen niet de kwaliteit hebben die werd verondersteld en daardoor het halffabrikaat niet aan de gestelde specificaties voldoet, dan is dit het probleem van de klant. Hij heeft immers de betreffende grondstof aangeleverd. In een dergelijk geval brengt Korrel wel de compounding fee bij de klant in rekening als dekking van de manuren, machine-uren en verkoopmarge. Claims in verband met kwaliteitsproblemen worden naar de ervaring van Korrel over het algemeen zonder mankeren gehonoreerd.

Uit de gesprekken blijkt, dat gerezen problemen met een levering meestal min of meer routinematig door de medewerkers van de afdeling inkoop direct met hun contactpersonen bij de leverancier in een goede verstandhouding worden 'geregeld'. Het zijn problemen die met een zekere regelmaat voorkomen, maar het gaat daarbij op het totaal van de leveringen om een betrekkelijk klein percentage. Waarschijnlijk kan deze werkwijze ook slechts bestaan bij de gratie van dit kleine percentage.

Daarnaast wordt als verklaring van deze soepele gang van zaken door verschillende respondenten aangevoerd dat men te maken heeft met grote ondernemingen, waarmee vaak reeds een langdurige relatie bestaat. Dat noemt bijvoorbeeld de zegsman van Korrel als verklaring van het feit dat er vrijwel nooit problemen over claims naar aanleiding van kwaliteitsproblemen met grondstoffen ontstaan:

$R$ : Het werkt ook goed, omdat we vaak of bijna altijd laten we zeggen in een multinational-achtige omgeving werken.

I: Waarom is dat belangrijk?

$R$ : Ik denk wel dat dit belangrijk is. We hebben ook wel eens producties voor wat kleinere ondernemingen en daar is het iets moeilijker overeenstemming te bereiken over een claim dan bijvoorbeeld met DSM of Dow, ik noem maar even twee namen. Die begrijpen heel snel dat het gewoon aan hen ligt en die gaan daarvoor ook niet hun verantwoording uit de weg, laat ik het zo maar noemen. En overeenstemming op basis van, hoe moet ik het noemen, een soort gentlemen-achtige gevoelens die zijn bij die grote ondernemingen wat meer aanwezig dan [bij de kleinere].

I: Waarom zou dat bij de grote ondernemingen meer aanwezig zijn? 
$R$ : Ja, dat blijkt uit de praktijk tenminste, ik weet ook niet waarom. Omdat het hun geld niet is, of omdat ze professioneel genoeg zijn om te onderkennen dat ze fout waren, of dat ze niet op lange termijn problemen willen hebben. Je moet Korrel binnen [de grootste moedermaatschappij] zien en er zijn bepaalde aspecten die gewoon op de lange termijn bekeken worden. Kijk, een productie van bijvoorbeeld 100.000 kilo, daar hangt misschien een half miljoen gulden aan grondstoffen mee samen. En dat gaat bijna altijd goed, maar daar zitten wel eens slippers tussen. In elke onderneming worden wel eens fouten gemaakt. Wij merken gewoon in de praktijk als wij bijvoorbeeld een claim plaatsen, die wij reëel achten, dat die voor $90 \%$ gewoon altijd meteen wordt goedgekeurd door de tegenpartij, en die $10 \%$ die dan nog overblijft dan wordt het $80 \%$ van dat bedrag of zo. Dat blijkt uit de praktijk. En dat heeft nog nooit geleid tot enig juridisch geschermutsel. Zover komt het belemaal niet. (Korrel)

Bij Folie wordt een vergelijkbare verklaring gegeven. Over de verhouding met de leveranciers wordt opgemerkt:

"Kijk, dat spel is zo groot dat niemand van die spelers het zich kan permitteren om daar heisa om te maken. Wij als grootste koper en zij als grootste spelers: in die relatie ga je niet vechten, want je hebt elkaar nodig... Wat daar speelt is met name... ja, hoe moet ik dat zeggen... Je hebt een hoop tegenstrijdige belangen, want er wordt tot op de laatste cent geknokt over prijzen, met name in dit soort markten, omdat het een business is van hoge volumes en kleine manges. Maar je blijft elkaar nodig hebben, dus je gaat het niet bederven op een transactie van 100.000 gulden." (Folie)

We zullen nog zien dat over de verhouding met de klanten ongeveer hetzelfde wordt gezegd. De grote bedrijven doen niet moeilijk bij het afwikkelen van problemen. Dat ziet men eerder gebeuren met de (enkele) kleinere bedrijven waarmee men zaken doet. Maar ook met kleinere leveranciers worden problemen blijkbaar uiteindelijk in der minne opgelost, want geen van de respondenten kan zich in de relatie met leveranciers een kwestic herinneren die in de afgelopen drie jaar tot juridische stappen heeft geleid.

\subsection{Klanten}

De relatie met de klanten in deze branche levert een iets minder maar toch nog vrij rimpelloos beeld, als we afgaan op hetgeen de respondenten daarover zeggen. Wel is het scala van problemen iets groter. Naast kwaliteitsproblemen worden er in een enkel geval een betalingsprobleem en problemen rond de levering gesignaleerd.

Aan de verkoopzijde liggen door de bank genomen de verhoudingen niet veel anders dan aan de inkoopzijde. Men doet veel zaken met grote (vaak multinationale) ondernemingen. Leveranties aan klanten vinden plaats binnen een juridisch kader van jaarlijks opgestelde 'raamcontracten' of 'overall contracten' en naar 
anleiding van orders. De raamcontracten bevatten ook hier in de eerste plaats zo precies mogelijk specificaties van de op afroep te leveren producten, prijsafspraken gekoppeld aan geleverde hoeveelheid en voorts leverings- en betalingsafspraken. Bij Folie worden de raamcontracten geheel, en bij Korrel voor een belangrijk deel, afgesloten door het Europese hoofdkantoor, respectievelijk het moederbedrijf. Daar worden ook de orders verdeeld over de verschillende plants. Korrel verkoopt zijn 'eigen omzet' in feite aan het moederbedrijf, dat het uiteindelijk aan de klanten verkoopt. Rubber en Compound opereren wat de verkoop van producten betreft geheel zelfstandig.

De relatie met in ieder geval een belangrijk deel van de klanten heeft een duurzaam karakter. Men doet al jaren zaken met elkaar en in een enkel geval zijn de producten van het bedrijf zelfs in samenwerking met de (technische afdeling van de) klant ontwikkeld. Orders, leveranties en betalingen zijn in deze branche van productiebedrijven constante stromen, die het nodige administratieve verkeer tussen het bedrijf en de klant met zich mee brengen. Deze innige relatie komt bij Rubber tot uitdrukking in een administratieve samenwerking die de kant opgaat van administratieve integratie. De administratieve handelingen verlopen volgens bepaalde routines. Aangezien de klanten (en zeker de grote ondernemingen daaronder) verwachten als koningen behandeld te worden, krijgen deze routines vaak de vorm die de klant wenst. Als deze routines geïnstalleerd zijn gaat er doorgaans weinig mis. Dat geldt in ieder geval voor defecten en betaling.

\section{Organisatorische vervlechting: Rubber in de slagschaduw van reuzen}

De banden tussen bedrijf en klant zijn niet bij alle bedrijven even nauw aangehaald als bij Rubber. Dit bedrijf verkoopt een belangrijk deel van de omzet (onderdelen voor kantoormachines als faxen, printers en kopieerapparaten) aan een beperkt aantal multinationale elektronicafabrikanten. Met deze klanten bestaan duurzame en zeer nauwe relaties. De relatie met dergelijke klanten heeft veel weg van wat wel 'verticale quasi-integratie' wordt genoemd: er is hiërarchie zonder eigendom. ${ }^{3}$ Soms worden producten in samenwerking tussen (de technische afdelingen van) klant en bedrijf ontwikkeld, die dan gedurende enkele jaren (zolang als een bepaald model van het eindproduct in de verkoop is) wordt geleverd. In contractueel opzicht lijkt de klant de broek aan te hebben. In de raamcontracten worden de producten uitputtend gespecificeerd, waarbij (zoals we gezien hebben) de klant zich soms ook bemoeit met de inkoop van de door het bedrijf te verwerken grondstoffen. Ook moet het bedrijf zich voegen naar de betalingsroutines van 
de klanten. De dominante opstelling van dergelijke klanten wordt ook met zoveel woorden door de zegsman van Rubber aangegeven:

"Het is niet meer zoals vroeger: de oude klant en een oude leverancier en je zegt maar wat je hebben wil en ik lever het wel, je moet me niet vragen hoe ik eraan kom, hoe ik het gemaakt heb etc., etc. En als de prijs maar goed is. Dat is tegenwoordig niet meer zo. Ze willen echt alles weten. Ze willen tegenwoordig zelfs weten hoe duur het is, wat onze uurtarieven zijn, hoeveel stuks we per uur maken etc. Daar hebben ze geen donder mee te maken. Wel globaal kunnen we vertellen hoe we het maken. Maar het gaat heel ver. Eigenlijk wordt je een onderdeel van je klant."

Deze opstelling van klanten komt deels voort uit het feit dat de klant op zijn beurt wat betreft de kwaliteit van zijn product afhankelijk is van wat zijn toeleveranciers kunnen presteren. Als een elektronicafabrikant een betrouwbaar product wil leveren of zelfs bij zijn marketing een 'zero-default policy' wil voeren, vraagt hij om grote problemen als hij zijn leveranciers van onderdelen veel discretie geeft over de kwaliteit van de onderdelen die zij aandragen. Hierboven is al een voorbeeld genoemd van de risico's die de klant dan loopt. Vandaar waarschijnlijk dat men het zekere voor het onzekere kiest en ook alle relevante details regisseert.

Deze quasi-integratie komt tot uitdrukking op het vlak van de orderadministratie en de betalingsmethodiek. Het heeft zin hierop iets dieper in te gaan, omdat het ook iets zegt over de manier, waarop de kans dat problemen op deze terreinen zullen ontstaan, wordt geminimaliseerd.

\section{Administratieve vervlechting: betalingsroutines bij Rubber}

De meeste klanten van Rubber zijn constant producerende bedrijven die op basis van het raamcontract een regelmatige stroom orders (afroepschema's) naar Rubber sturen voor leveringen van producten. Deze orders komen via de computer binnen en worden op dit moment nog handmatig verwerkt in de productieschema's. Ook de facturering doet men nog zelf. Maar er wordt gewerkt aan een verdergaande administratieve integratie:

R: Heel veel zaken gaan vanaf nu via EDI (Electronic Data Interchange). [kantoormachinefabrikant] doet het. [elektrische apparatenfabrikant] doet het. Wij krijgen nu het papierloze kantoor. Dan krijg je inkoop orders en ook verkooporders... Wij willen dat op den duur ook met onze leveranciers gaan opzetten, maar we spelen het cerst met onze klant, aan onze klantenkant, onze verkoopafdeling in feite om daar ervaring mee op te doen. Maar [elektrische apparatenfabriek] bestelt al in feite via de computer, die stuurt zijn afroepschema's... Vroeger kreeg je van die grote vellen papier... Die komen op het ogenblik nog bij ons binnen op een aparte $p c$, daar stoppen we gewoon [...] Maar de bedoeling is dat [elektrische apparatenfabriek] rechtstreeks onze eigen computer ingaat, dat we eigenlijk helemaal niet meer zien dat er orders binnenkomen. Nee, dat zie je straks wel aan productieschema's 
en afleverschema's. Ja, dat gaat heel ver. Dat gaat zelfs zover, dat we straks leveren en dat er helemaal geen facturen meer gemaakt worden, dat er elektronisch facturen gestuurd worden en dat we onszelf betalen.

I: Wacht even, dat gaat te snel.

$R$ : Ja, dat gaat snel hè...

I: Dat lijkt me een witstekende regeling..

$R:$ Nee, dat is heel simpel. Ik ben daarvoor in Singapore op een cursus geweest, daar zijn ze al heel ver daarmee. Trouwens hier in Europa ook hoor, [Kantoormachinefabriek] hier [ter plaatse] is er ook al heel erg ver mee...Je stuurt je spullen naar [elektrische apparatenfabriek] toe, die komen daar in het magazijn... Daar moeten papieren bij, want een vrachtwagenchauffeur doet niets zonder papieren, dus daar moet wel een stuk papier bij, maar dat is geen factuur. 'Transportorder'. De factuur gaat automatisch over de lijn naar [elektrische apparatenfabriek] toe, die wordt er ontvangen en gaat daar de boekhouding in en daar is aan gekoppeld, omdat eh...en dan betaal je ook gewoon. We hebben een afspraak van betalen binnen 14 dagen en daar zit aan vast dat die dingen automatisch binnen 14 dagen betaald worden. Dat gaat allemaal automatisch, daar komt in feite geen vent meer aan te pas. Als alles goed gaat hoor, dat duurt nog tien jaar voordat dat allemaal goed gaat. Het gaat stapje voor stapje. Nu komen de orders binnen, en we zijn proeven aan het doen met het oversturen van facturen. het zijn maar fake-facturen hoor. Onze automatisering en die van [elektrische apparatenfabriek] zijn daar volop mee bezig en dat gaat prima. In Singapore doen we dat al, daar zijn we er direct mee begonnen.

$\mathrm{Nu}$ komen [in Nederland] de orders over de lijn binnen en worden ze handmatig in ons systeem ingevoerd, zoals je normaal altijd een order kreeg via de telefoon of op een stuk papier en dan werd er door een juffrouw een order ingetoetst. Dat gaat straks automatisch en dan zie je het niet eens meer. (Rubber)

Uiteraard kunnen deze informatiestromen wel gecontroleerd worden. Verschillende klanten hebben overigens een eigen betalingsregime:

$R$ : Bij [kantoormachine fabrikant] hebben ze nog een heel ander systeem, het zogenaamde 'pay on production'. Daar stuur je dus goederen naar [kantoormachine fabrikant] toe, die gaan dan naar het magazijn en dan betalen ze niet, daar factureer je ook niet. Je factureert pas op het moment dat zij het afnemen uit hun magazijn en het versturen naar hun productieafdeling en het uit hun magazijn weggaat. Dus 'pay on production': zij betalen pas dan, maar dan betalen ze ook onmiddellijk. Dan sturen zij zelf de factuur die wij eigenlijk zouden moeten sturen, zij maken dus zeg maar de Rubber-factuur, zij crediteren ons, net andersom, zij zeggen nou heb je zoveel van ons tegoed en dan betalen ze hem ook gelijk. Zodra er iets is afgenomen voor de productie betalen ze ook. Dat is een proef waar ze mee bezig zijn, maar het functioneert wel. En zo gaat dat in de toekomst. [...] 
In Engeland doen we een proef met 'pay on receipt'. Wij sturen ook geen facturen, maar sturen het daarheen en dan betalen zij op het moment als ze het ontvangen. Aan deze administratieve arrangementen zitten wel juridische (bewijstechnische) haken en ogen, maar daar wordt aan gewerkt. Het optimisme waarmee deze ontwikkelingen worden omarmd lijkt deels gebaseerd op het feit dat zich rond de betaling thans reeds weinig problemen voordoen:

"Onze klanten zijn grote jongens en onze leveranciers zijn grote jongens en die doen niet zo moeilijk. Dat is heel gek, maar dat komt waarschijnlijk ook omdat ze...kleinere firma's aan wie je levert, dat zijn meestal private ondernemingen, vaak kleinere en die zitten veel scherper op de centen dan bijvoorbeeld DSM. Er zijn klanten van ons die betalen gewoon een factuur twee keer en als je ze niks vertelt dan laten ze dat lopen. dat zijn mammoetorganisaties, die.. voor hun is het eigenlijk maar peanuts...nee daar hebben we weinig problemen mee. (Rubber)

De grote bedrijven zijn in ieder geval kredietwaardig en betrouwbare (zij het misschien niet altijd snelle) betalers. Dat is ook de reden dat niet met bankgaranties en kredietverzekeringen wordt gewerkt. Dergelijke klanten hebben hun eigen vaste betalingsroutine waarin het bedrijf zich blijkbaar schikt. Men lijkt in deze gang van zaken te berusten als ware het overmacht, maar waarschijnlijk stoelt deze berusting voor een deel tevens op begrip voor dergelijke routines, want het bedrijf zelf heeft namelijk ook een vaste betalingsroutine ten opzichte van zijn eigen leveranciers.

Bij Folie lopen orders en betalingen via het hoofdkantoor in Luxemburg. Op de afwikkeling daarvan heeft men op dit niveau weinig zicht. Wat de plant wel zelfstandig verkoopt is materiaal dat niet aan de kwaliteitsspecificaties voldoet ('off-spec'materiaal) en gerecycled materiaal. Daarbij doen zich nooit problemen voor. Als reden daarvoor wordt in de eerste plaats genoemd, dat men voor deze producten slechts enkele afnemers heeft die voor het hele concern werken ("...die gaan niet hun business at risk zetten door hier problemen te maken") Als er al eens problemen zijn dan komt men daar in overleg uit. Het zijn redelijk grote bedrijven en het gaat om relatief kleine belangen (van hoogstens $f .75 .000$ ) en een zeer klein deel van de omzet van de plant.

Volgens de zegsman van Korrel doen zich rond betalingen nooit problemen voor. Dat verklaart hij uit het feit dat het doorgaans grote bedrijven zijn, waarbij de kans op liquiditeitsproblemen zeer klein en in de praktijk gelijk aan nul gebleken is. Men betaalt binnen de gestelde betalingstermijn van een maand. Als er al problemen zijn over een betaling heeft dat meestal te maken met cen vermeende fout in de factuur. Bij Pellet wordt hetzelfde beeld geschilderd.

Bij Compound levert men aan diverse vaste afnemers die een open rekening hebben. Men hanteert een betalingstermijn van 30 tot 60 dagen. Dit wordt in feite als krediet beschouwd en afgedekt met een kredietverzekering. Als de kredietverzekeraar geen kredietlimiet geeft dan vraagt men een bankgarantie. Blijkbaar 
ligt het vragen van bankgaranties bij vaste klanten gevoelig. Toen een bestaande kredietlimiet van een klant werd verlaagd, heeft men met succes getracht die beslissing te laten herzien. Een bankgarantie vragen van een vaste klant vond men 'gênant'.

Het gebruik van methoden om betalingsrisico's af te dekken vertoont overigens geen duidelijk patroon. De verwachting, dat dergelijke zekerheden vooral belangrijk zijn met kleinere en incidentele afnemers, komt niet helemaal uit. Een kredietverzekering wordt bijvoorbeeld wel gehanteerd door het Folie-concern voor de reguliere afzet via het hoofdkantoor, terwijl het naar verluidt toch gaat om vaste grote klanten. Voor de producten, die de fabrick zelf verkoopt is geen kredietverzekering afgesloten. Rubber maakt geen gebruik van kredietverzekering of bankgarantie, omdat dit gezien de grootte van de klanten niet nodig geacht wordt. Bij Korrel wordt evenmin gewerkt met kredietverzekering of bankgarantie.

Over het algemeen lijkt het feit dat de klanten grote ondernemingen zijn, voldoende waarborg tegen het ontstaan van betalingsproblemen. Men dekt zich ook niet stelselmatig in tegen het risico van wanbetaling. Betaling is een administratieve handeling die volgens een afgesproken (of door de klant bepaalde) routine verloopt. Problemen doen zich op dit vlak bijna nooit voor als gevolg van liquiditeitsproblemen. Juridische stappen worden op dit vlak dan ook hoogst zelden ondernomen. Alleen Rubber meldt een faillissement van een klant in Engeland bij wie nog rekeningen open stonden. Deze kwestie is vervolgens door het Engelse verkoopbureau van Rubber met behulp van een Engelse jurist afgewikkeld.

\section{Defecten}

Op de kwaliteit van het eigen product wordt door de bedrijven zelf nauwlettend toegezien. Steekproefsgewijs wordt nagegaan of het product aan de gestelde kwalificaties voldoet. Men is ook onder ISO verplicht kwaliteitscontrole te organiseren. De leidende gedachte achter dit vereiste is, dat door de bron van de defecten op te sporen toekomstige fouten kunnen worden voorkomen. Als de fout bij de toeleverancier gemaakt is dient deze in ieder geval van het gebrek op de hoogte gesteld te worden. Als de fout tijdens het eigen productieproces is gemaakt en het bedrijf het gebrek zelf heeft geconstateerd dient men in beginsel (aan de instantie die de kwaliteitsaudits verricht) duidelijk te kunnen maken, welke maatregelen er zijn getroffen om deze fout voortaan uit te sluiten. Ook de klant voert ingangscontroles uit en is eveneens onder ISO verplicht fouten aan het leverende bedrijf te melden, opdat dit in staat is de bron van de fouten zo mogelijk te ecarteren. Ook in dergelijke gevallen moet het bedrijf kunnen laten zien welke maatregelen er zijn getroffen om dergelijke fouten te voorkomen. Er wordt dus veel gedaan om 
te voorkomen dat producten geleverd worden, die niet aan de verlangde specificaties voldoen.

Desondanks gaat er zo nu en dan toch iets mis met de kwaliteit van het product. Het bedrijf krijgt daarover (in het kader van het kwaliteitssysteem) in ieder geval feedback van de klant. In deze branche worden producten gedetailleerd technisch gespecificeerd, wat discussie over het al dan niet aanwezig zijn van een gebrek vrijwel uitsluit. De vraag is dan wel waar de fout is gemaakt. Als het gaat om defecten in een hele levering en de fout is door de fabriek zelf gemaakt, dan is de standaardoplossing, dat de klant voor de levering gecrediteerd wordt en een nieuwe levering ontvangt. De zegsman van Korrel noemt het voorbeeld van een levering die door een spuitgietfabriek voor het vervaardigen van witte bromfietshelmen werd gebruikt, welke na productie zwarte puntjes bleken te hebben. In dergelijke gevallen kan vaak naar aanleiding van de claim van de klant (aan de hand van bewaarde monsters) worden nagetrokken waar de fout is gemaakt. Ligt het aan een van de grondstoffen dan wordt de claim verwezen naar de toeleverancier. In het geval dat dit niet (meer) duidelijk is aan te tonen of de fout in de fabriek zelf is gemaakt, wordt de klant voor de levering gecrediteerd.

Bij gebreken in een klein deel van de geleverde producten, zoals wel voorkomt bij partijen kant en klare onderdelen, is de gang van zaken vaak meer rourinematig. Rubber heeft de ervaring dat grotere klanten daarbij anders te werk gaan dan de kleinere afnemers:

$R$ : Als ik hier naar X, een kleinere firma hier, die bijvoorbeeld schuifdaken maaks of iets dergelijks en waar 80 man werkt, meneer als we daar 100 onderdelen leveren en er zijn er 5 fout, dan krijg je die 5 wel terug. Maar als we cen [kantoormachinefabrikant] 100.000 onderdelen leveren en er zijn er 500 fout. die zien we nooit meer terug. Als bet beneden de zoveel procent is doen ze er niks mee. Ze vertellen je wel vaak.., ze beginnen nu wel met engeneeringsafdelingen die al die fouten dan bekijken en zeggen van we bebben zoveel fouten gehad enne je hoeft niks te betalen, maar die en die fouten hebben we geconstateerd. Maar meestal zijn het fouten van henzelf, met uitpakken in het magazijn...

I: Er zit een bepaalde marge op?

$R:$ Nou, tegentwoordig de marges worden wel kleiner... zero defect of boe noemen ze dat tegenwoordig...

I: Er mag eigenlijk niks..

R: Er mag eigenlijk niks. Er zijn klanten bij ons... [elektronicafabriek] in Nederland heefi een zero defect... die sturen elk ding terug wat ze aan de band eruit halen..

1: Dat ondergraafi weer Uw stelling dat de groten niet moeilijk doen.

$R$ : Ja, ze sturen het terug, maar je boeft het niet te betalen. [...] Behalve natuurlijk als ze partijen van 20.000 stuks afkeuren al bij ingangscontrole of zoiets dengelijks. dan betaal je dat natuurlijk wel he. 


\section{Alleen de kleine dingetjes.}

R: Die betaal je niet nee. Nee, dat kost ze teveel geld. Als ze er eén uitsorteren en ze moeten dat ook nog factureren, want dat is moeilijk hoor, voor zo'n organisatie dan via de computer - want ze kunnen niet zomaar een bonnetje schrijven - dat is beel eng moeilijk hoor.. "(Rubber)

De behandeling van kleinere defecten is bij de grotere klanten van Rubber vooral een kwestie van administratieve routine, en het zijn gebeurtenissen die vrijwel nooit leiden tot onenigheid. Als het voorkomen van defecten binnen aanvaardbare marges blijft kan de soepele afhandeling van dergelijke kwaliteitsproblemen een indicatie zijn van de goede verstandhouding tussen het bedrijf en de klant. Maar het is natuurlijk ook relatief goedkoop. Zo blijkt de zegsman van Rubber zijn grotere klanten bij hun genereuze behandeling van kleine defecten niet meer dan puur zakelijke overwegingen toe te dichten.

Tenslotte komt het soms voor dat een gebrek in een product niet door de klant wordt ontdekt dan nadat het in de productie is gebracht. De klant kan daardoor schade lijden. De zegsman van Folie noemt bijvoorbeeld het geval dat aan een Italiaanse fabriek folie was geleverd waarin gedroogde boontjes moesten worden verpakt. Door een verkeerde kwaliteit van het verpakkingsmateriaal liet de lijm waarmee de verpakking werd afgesloten korte tijd later los. De hele fabriek kwam dientengevolge onder de boontjes te staan, die uiteraard verloren waren. Rubber verhaalt van een geval, waarin rubberen afdichtingsringen voor een waterleiding in Afrika (overigens een klimaat waarvoor de ringen niet berekend waren) na verloop van tijd bleken te lekken. De schade vloeide in dit geval voort uit de noodzaak om de waterleiding weer op te graven om het euvel te kunnen verhelpen. Dergelijke gebeurtenissen zijn incidenten die niet frequent voorkomen. Niettemin zijn zulke risico's doorgaans met een productaansprakelijkheidsverzekering afgedekt, hetzij door het bedrijf zelf hetzij door de moedermaatschappij.

\section{Levering aan de klant}

Tussen de order en de betaling vindt de levering plaats. Alleen Rubber meldde hierover problemen. Er doen zich daar met sommige klanten wel met enige regelmaat problemen voor. Aan een deel van de klanten wordt 'af fabriek' geleverd en eventuele verschillen tussen wat wordt afgehaald en bij de fabriek van de klant aankomt, zijn de verantwoordelijkheid - en voor rekening - van de klant. Dan zijn er geen problemen. Maar bij levering 'aan fabriek' schuift de klant de verantwoordelijkheid en de rekening naar de leverancier. Volgens de pay on receipt betalingsroutine wordt alleen betaald wat wordt ontvangen. Wanneer het om substantiële verschillen gaat en de fout is niet door het bedrijf zelf gemaakt, dan ontstaat een probleem, dat niet gemakkelijk gecorrigeerd kan worden. De klanten zijn meestal ISO-gecertificeerd, wat betekent dat mag worden aangenomen, dat ze 'zorgvuldig 
tellen'. Bovendien wordt er just in time geleverd, dus tegen de tijd dat het verschil bij de Rubber bekend wordt is het onderdeel al in de productie verwerkt, zodat controle van de lading zelfs niet meer mogelijk is. In dergelijke situaties trekt de leverancier aan het kortste eind. Er kan nog verhaal bij de transporteur worden gehaald, want het is aan te tonen hoeveel producten hij heeft vervoerd. Maar de vervoerders betalen, overeenkomstig hun standaardvoorwaarden, slechts een klein bedrag voor elke productkilo die verloren gegaan is. Daarom heeft men deze risico's afgedekt met een eigen wereldwijde transportverzekering via het moederbedrijf.

Dit type problemen wordt dus niet routinematig afgedaan, omdat er gezocht wordt naar waar de fout gemaakt is. De klant stelt zich daarbij blijkbaar formed (zich beroepend op zijn betalingsvoorwaarden) op en behandelt het als een probleem van zijn leverancier

\subsection{Concurrenten}

Er is ook gevraagd naar eventuele problemen met concurrenten. Een respondent wees erop dat dergelijke kwesties zich in de industriële marketing (dus in de productielijn) minder vaak voordoen dan in de commerciële marketing (in de distributielijn). Toch was de vraag voor deze branche wel op zijn plaats, want het bleck dat zich op dit vlak wel eens problemen voordoen. De problemen houden voornamelijk verband met de technologische know-how die in deze branche wordt ge bruikt. Eigen producten worden meestal beschermd met een patent en er wordt op toegezien dat deze niet door de concurrentie worden geschonden. Bij Folie werd de patentbewaking verricht door de juridische afdeling van het hoofdkantoor in de Verenigde Staten. Meer zelfstandig opererende bedrijven moeten dat zelf doen. Bij Rubber hadden zich op dit vlak geen problemen voorgedaan, maar bij Compound wel. Een groot chemieconcern had een patent van Compound geschonden en men had daarin ogenblikkelijk juridische stappen ondernomen. Men had zich gewend tot een van de grote advocatenkantoren in de Randstad om aan deze toestand een einde te maken. Deze kwestie liep uit op een gerechtelijke procedure waarin uiteindelijk ten gunste van Compound werd beslist.

Een ander gevoelig punt heeft betrekking op het personeel. Met name het technisch personeel beschikt (onder meer door de bedrijfsopleiding, waarin veel wordt geïnvesteerd) over veel bedrijfsspecifieke kennis en er wordt door de concurrentie regelmatig getracht dergelijke medewerkers weg te kopen. Bij Folie heeft men in verband daarmee in de arbeidsvoorwaarden een concurrentiebeding opgenomen:

"Het is meer cen psychologische zet naar onze mensen toe dan een zet waar je formeel iets mee kan. Als [de concurrent] mij mongen twee keer zoveel salaris biedt, ik noem maar iets, dan zal Folie b.v. mij niet tegen kunnen houden. "(Folie) 
In feite wordt tegen het vertrek van een medewerker naar een concurrent geen juridische stappen ondernomen, omdat de kans op succes van een dergelijke actie niet groot wordt geacht in verband met de bewijslast. Bij Compound meldde men nog een geval van enkele oud-werknemers, die vlak over de grens met bedrijfskennis een eigen bedrijf waren gestart. Men had in dit geval een advocatenkantoor in de regio in de arm genomen. Daarmee had men 'politieke' bedoelingen, dat wil zeggen dat het doel was de zaak te traineren, in de hoop dat de onderneming daardoor in financiële problemen zou komen. Er was gedreigd met een kort geding, maar men had niet echt de intentie om het uit te vechten. De bewijslast was moeilijk en het risico van een enorme schadeclaim werd gevreesd. Men voorzag een schikking.

\subsection{Summer}

Summer is een kunststofverwerker die afwijkt van de anderen. De onderneming heeft meer weg van een bouwbedrijf dat werkt met kunststof. Van de gevelelementen bestaan een serie typen die op maat worden geconstrueerd. De onderneming heeft weinig vaste klanten, op 'de overheid' na. Het bedrijf is aangesloten bij een branchevereniging bij wijze van kwaliteitswaarborg. ISO-certificering is niet aan de orde geweest. De belangrijkste categorie problemen vormen de betalingsproblemen. Wanneer de termijn van 30-dagen wordt overschreden, komt een administratieve procedure op gang die uiteindelijk eindigt bij de vaste advocaat, die zal dreigen met een incassotraject. Het afgelopen jaar is dat punt drie maal bereikt. De kunststof wordt geleverd door een enkele leverancier van profielen. De contractuele planning van de bestellingen is minimaal. Er zijn mondelinge afspraken over kortingen en voor het overige wordt er besteld en geleverd. Dat loopt naar verluidt op rolletjes. Eventuele kwaliteitsproblemen worden in overleg opgelost. De firma is nog nooit daadwerkelijk in een gerechtelijke procedure betrokken geweest.

\subsection{Resumerend}

De hierboven besproken bedrijven vertonen in hun structuur en werkwijze tal van verschillen. Een sterk afwijkend geval is Summer. Het vertoont meer de kenmerken van een bouwonderneming. Van de overige bedrijven valt desondanks een enigszins samenhangend beeld te construeren. Uit de mist van details komen enkele gemeenschappelijke trekken naar voren wat betreft het afhandelen en voorkomen van problemen.

Aan de kant van de opdrachtgevers doet men zaken met overwegend grote of zeer grote ondernemingen, die hoge eisen stellen. Dat betekent onder meer dat er een geringe tolerantie is voor fouten. Er wordt dus het nodige gedaan om fouten 
te voorkomen. Er worden zeer precieze afspraken gemaakt. Soms wordt bij de voorbereiding van de productie al op voorhand getracht fouten te voorkomen. Het gehele productieproces wordt voortdurend op reflexieve wijze gecontroleerd. Van productiefouten is vrij objectief vast te stellen wie er voor verantwoordelijk is. Dit is zelden een bron van onenigheid tussen het bedrijf en opdrachtgevers. Bovendien probeert men aan de fouten die desondanks geconstateerd worden preventielessen te ontlenen. Alles is er op gericht de productiemachine (niet alleen die van het bedrijf, maar ook die van de opdrachtgever) zo frictieloos mogelijk te laten draaien. Ook de leveranciers dragen daaraan bij. Het gaat hier veelal om grote chemische concerns die gewend zijn aan strenge eisen te voldoen. Ook hier is de verantwoordelijkheid voor fouten objectief vaststelbaar en zelden een bron van discussie. Fouten worden voor het merendeel voorkomen, en als ze optreden worden ze in overleg afgewikkeld. Verschillende verzekeringen dekken de risico's van kostbare fouten af. Betaling is vooral een kwestie van administratieve routine. Daarom doen zich in deze constellatie zelden geschillen voor.

Van bijzonder belang zijn de hier gesignaleerde kwaliteitssystemen. Enerzijds de ISO-kwaliteitszorg, die door verschillende bedrijven blijkt te zijn ingevoerd. Ze lijken een treffend voorbeeld van de reflexieve methoden, zoals door Giddens omschreven. Anderzijds is er het 'eigen' kwaliteitssysteem van enkele grote opdrachtgevers, waarvan door Rubber gewag werd gemaakt. Volgens de zegsman van Rubber was met name dit laatste kwaliteitssysteem erg effectief. Maar de zegsman van Compound, die alleen met ISO-kwaliteitszorg werkte, meende dat dit systeem veel klachten voorkwam.

Er is de nodige afstand in de relatie met concurrenten. Men kent elkaar maar heeft zelden direct met elkaar te doen. Een enkele keer doet zich een conflict voor, dat meestal draait om de bescherming van know how. Daarover gaat men conflicten niet uit de weg. Ook gerechtelijke stappen worden niet geschuwd, maar duidelijk alleen wanneer men zich in het bedrijfsbelang bedreigd voelt. Zulke acties worden ondernomen om een tegenstander door dreigementen van koers te doen veranderen of desnoods via een rechterlijke uitspraak op de knieën te krijgen.

\section{Wegtransport}

In enkele opzichten lijkt deze branche meer op de kunststofverwerkende industrie dan op de aannemerij. In ieder geval een gedeelte van de branche is internationaal (dat wil vooral zeggen Europees) georiënteerd. Bovendien wordt er niet per se projectmatig gewerkt, wat betekent dat het in beginsel mogelijk is vaste relaties op te bouwen. Het wegtransport heeft met de aannemerij gemeen, dat de marktverhoudingen sterk geïnstitutionaliseerd zijn. Verdrag, wet en standaardvoor- 
warden reguleren tal van aspecten van de vervoersovereenkomst. Gedeeltelijk speelt daarbij - vooral op Europees vlak - de behoefte aan uniformering een rol. Daarnaast is de wens, de verhouding tussen vervoerder en opdrachtgever in termen van rechten en plichten in evenwicht te brengen, een zelfstandig motief voor regulering geweest. Op de achtergrond vermoedt men de invloed - zoals in de aannemerij - van vrij scherpe concurrentieverhoudingen.

Anders dan in de industrie ligt bij de dienstverlening het accent in de relationele context sterk op de opdrachtgevers, om de simpele reden dat er niet zo ontzettend veel wordt ingekocht.

\subsection{Leveranciers}

De inkoop betreft in hoofdzaak brandstof, banden, trekkers/trailers en onderdelen. Voor dieselolie - meestal de grootste post - heeft men veelal vaste adressen, die men gekozen heeft op grond van de prijs. Gezien de hoeveelheden die men afneemt (een middelgrote vervoerder noemde een verbruik van 1,8 miljoen liter per jaar) is elke cent kwantumkorting die men kan bedingen interessant. Sommige bedrijven onderhouden een eigen pomp, anderen tanken bij een pomp in de buurt van het bedrijfsterrein. Ook voor de banden heeft men zijn vaste adressen, al komt het daar vaker voor dat bestellingen gespreid worden over enkele leveranciers. Als reden voor deze praktijk wordt vermeld dat men zodoende niet afhankelijk is van een enkele leverancier. Daarbij heeft men niet alleen een eventuele stagnatie van de leveranties in gedachten; men heeft ook graag meerdere ijzers in het vuur met het oog op de prijsontwikkeling. Op die manier kan men soepel bestellingen verschuiven in de richting van de meest aantrekkelijke prijs, zonder dat er abrupt naar een andere (en misschien ook wel onbekende) leverancier moet worden overgeschakeld. Ook voor de aankoop van trucks en trailers bestaan er veelal vaste contacten met diverse dealers (variërend van 2 tot 5 ). De grootste onderneming heeft zelf twee dealerschappen en bestelt direct bij de fabriek.

De inkoop verloopt doorgaans zonder veel fricties. De kans op problemen wordt verkleind door enkele factoren. Men doet zaken met leveranciers met wie men vaak lange tijd goede ervaringen heeft. De ISO-gecertificeerde bedrijven werken met de lijst van geaccepteerde leveranciers:

"In principe als we een nieuwe leverancier zouden aantrekken voor bepaalde onderdelen, ik noem maar iets: veren of banden, dan moet er in principe gehandeld worden volgens bepaalde normen die staan beschreven in een handboek; we hebben dus een aantal handboeken, een procedure handboek en een lijst van geaccepteerde leveranciers: daar moet hij dus op staan. Staat hij er niet op dan moet je cen zogenaamde proeforder plaatsen en na twee of drie keer kijken of het goed gaat en dan mag hij op de lijst. In principe mag je daar niet buiten bestellen, uiteraard in noodgevallen wel. Maar in principe moet je zeggen: dat is de lijst en daar bestellen we. 
Dat is allemaal vrij strikt geregeld. Dat zijn bepaalde normen en daar moet je je aan houden, want mensen komen kijken en die prikken gewoon, twee man een hele dag, door alles heen." (Jansen)

De vervoerder weet zich ten opzichte van de leverancier doorgaans in een sterke positie, omdat de overstap naar een concurrent (door lage transactiekosten) niet moeilijk is, dan wel bewust niet moeilijk is gemaakt door het spreiden van bestellingen over verschillende leveranciers (zoals bij de trucks). Deze verhouding speelt ook een rol in het geval er zich problemen aandienen:

"Als er nu bij die leveranciers, van auto', banden, een kink in de kabel komt: ze le. veren iets te laat of wat ze leveren niet helemaal goed of iets dergelijks: hoe wordt daar dan mee omgegaan?

"Dat wordt in principe dan teruggestuurd of teruggehaald, of er wordt gepraat over een korting, of een vergoeding of een creditnota of iets dergelijks. Er zijn, althans tot nu toe, eigenlijk nooit dusdanige problemen geweest dat daar rechtszaken van zijn gekomen. [...] Meestal lukt dat wel. Want uiteraard als je daar een flink bedrag per jaar aan afneemt dan [...] ligt dat wat makkelijker dan wanneer je een keer een auts knqhr an dav nist mest "Slanson)

Verschillende respondenten geven te kennen, dat er regelmatig onenigheid is met vrachtwagendealers over garanties. Dergelijke onenigheden worden voornamelijk 'uitonderhandeld'. (Pietersen)

Bij de contractuele planning van de inkoop van brandstof en banden spelen de (periodieke) prijsafspraken de hoofdrol. Over de schriftelijke vastlegging van die afspraken wordt verschillend gedacht. Soms wordt schriftelijke vastlegging van belang geacht, omdat daarop bij onenigheid over afspraken op kan worden teruggevallen (Gerritsen); soms wordt het niet nodig geacht (Klaassen); en soms wordt het als hinderlijk ervaren, omdat dan minder gemakkelijk van leverancier zou kunnen worden gewisseld (Willemse).

\subsection{Opdrachtgevers}

De bedrijven van de meeste respondenten vervoeren zowel binnen Nederland als naar het (Europese) buitenland. Het accent ligt overwegend op het internationaal transport, met name naar Duitsland.

Sommige 'vaste' opdrachtgevers zijn grote bedrijven. Een beperkt aantal van dergelijke klanten kan bij een transporteur voor een verhoudingsgewijs groot deel van de omzet zorgen (er worden percentages genoemd van 65 tot 90 ). Als vootdeel van deze vaste opdrachtgevers (naast bedrijfszekerheid) wordt genoemd dat ze, als men tevreden is, trouw zijn. Als nadeel wordt genoemd dat ze zo mogelijk de prijs stellen.

"En als wij of iemand anders bij (grote opdrachtgever) $O$. komen en zeggen wij) doen het zelfde werk en doen het voor 5 cent minder, dan zal $O$. zeggen we bebben 
al een jarenlange relatie met $Z$. Ze leveren goed werk, want je moet uiteraard goed werk leveren, en we durven het met jou niet aan. Maar als de mensen van (grote opdrachtgever) $P$. zeggen er moet zoveel van de prijs af, dit jaar blijft de prijs betzelfde, maar ik kan het niet maken: ik heb opdracht van mijn directie om zoveel uit te geven en als jullie het daar niet voor doen, ja dan hebben we tien anderen. Wat dat betreft is het: iedereen vecht voor zijn eigen houtje. [...] Als je zegt ik wil 10 cent meer hebben, dan kun je dat wel willen maar dat krijg je niet. Of het moet zover komen dat men tekorten heeft, dat het zo druk is dat men te weinig trucks beeff, dan moet men uiteraard wel. "(Pietersen)

Met het goederenvervoer gaat regelmatig iets mis. De chauffeur is te laat, aanrijdingen, bij aankomst blijkt de lading niet te kloppen, goederen blijken verdwenen of beschadigd, om de meest voorkomende problemen te noemen. Soms verdwijnen hele trucks onderweg. Dergelijke kwesties worden soms langs juridische weg afgewikkeld.

Dat neemt echter niet weg dat er toch enkele factoren zijn aan te wijzen die de kans op klachten en onenigheden verkleinen. In de eerste plaats dient de standaardisering van de nationale en internationale vervoerscondities genoemd te worden. De nationale AVC-voorwaarden en de internationale CMR-voorwaarden voorzien onder meer in uniforme regels voor aansprakelijkheid in geval van schade aan ladingen. ${ }^{4}$ Dergelijke condities verkleinen de kans op onaangename verrassingen: bij alle vervoerders is men in dat opzicht doorgaans even goed of even slecht af. In de tweede plaats zijn de ondernemers op verschillende terreinen pro-actief bezig. Bijvoorbeeld op het vlak van de 'vervoerstechnische' kwesties, met name natuurlijk het op tijd afleveren. Verschillende vervoerders wijzen er met nadruk op dat het van groot belang is de ontvanger van een transport zo spoedig mogelijk op de hoogste te stellen van een te verwachten vertraging. Via communicatiesystemen (o.m. via satellietverbindingen) is men in staat vrij nauwkeurig de bewegingen van de trucks te volgen. Dat maakt het mogelijk de ontvanger precies op de hoogte te houden. Dit is vaak al voldoende om de klant tevreden te stemmen. (Thomassen) Dergelijke vertragingen dienen weer bij de afdeling planning gemeld in verband met de non-conformity review, een ISOprocedure, die het mogelijk maakt de oorzaak van regelmatige klachten op te sporen. Als het gaat om een chauffeur die regelmarig te laat komt, dan is dat aantoonbaar en wordt hij erop aangesproken. (Pietersen.)

4 De Algemene Vervoerscondities zijn het resultaat van overleg tussen het Ministerie van Verkeer en Waterstaat en een samenwerkingsverband van belangenorganisaties uit de transportwereld. De 'Coventions relatives au contracts de transports internationales de marchandises par route' zijn de dwingendrechtelijke bepalingen van een international verdrag over condities van internationaal vervoer. 
Ook op het vlak van de betaling geven enkele respondenten te kennen vooral het accent te leggen op preventie van betalingsproblemen. De solvabiliteit van de opdrachtgevers wordt vooraf nagetrokken en ook nadien gevolgd, onder meer op grond van het orderverloop en de betalingsdiscipline. Een respondent vertelde hoe een klant die solvabiliteitsproblemen ontwikkelt wordt geloosd: het is slechts nodig de prijs op te schroeven, opdat voor de diensten van de concurrent zal worden gekozen. (Thomassen)

Deze voorzorgsmaatregelen kunnen niet helemaal voorkomen dat er zich kwesties voordoen die tot claims leiden. De meeste standaardrisico's zijn via de verzekering afgedekt. Er is een verzekering voor vervoersaansprakelijkheid in verband met beschadiging of vermissing van vervoerde goederen. Een enkele keer ontstaan daarover claims.

".... dan komt er cen expert kijken en we zijn via de verzekeringsmaatschappij aangesloten bij de [rechtsbijstandverzekering] als er problemen zijn dan wordt de [rechtsbijstandverzekering] ingeschakeld. Die handelt dat verder af. Die komen een keer met ons praten of met de chauffeur praten: hoe was het precies, hoe zat dat

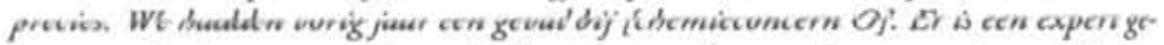
weest en dat loopt nog. Er is een lading geweest, dan worden er van bovenaf in een aantal luiken in zo'n container, daar worden dan een bepaald soort zakken ingehangen, nou daar zijn zakken gescheurd, van dat spul is op de vloer terecht gekomen. Dus dat is uiteindelijk niet verscheept kunnen worden, het is ergens anden moeten gelost worden. Daar loopt een claim over. En men is nog aan het bakkeleien of onze chauffeur nou schuld is of dat aan de hand van de scheur die de experts hebben vastgesteld [opdrachtgever] zelf schuld is. Dat zoekt die verzekeringsmaat. schappij uit en daar wordt een keer een uitslag over bepaald en dan betalen ze of de andere maatschappij betaalt." "(Hendrikse)

Maar het is om diverse redenen van belang het aantal van dergelijke claims te beperken:

"En met die vervoersaansprakelijkheidsverzekering: 16 grote pallets kun je tellen, en dan moeten er geen vijftien opstaan, want dan hebben we een probleem. Maar kijk, als je 1398 banden op een trailer worden gegooid door vier of vijf man, dan kun je tellen als een meikever, maar dat lukt je nooit. Maar goed, dan moet je dat onder voorbehoud op je vrachtbrief opnemen. Als je dat doet en het zaakje wordt daarna verzegeld, dan is dat ook nog niet zo'n probleem. Maar als je dat niet doet en er komen er maar 1298 uit in Engeland of Italië, dan mis je er honderd en dan heb je wel een probleem. En dan gaat de rekening in onze richting en dat proberen we uiteraard [te beperken] zowel naar onze opdrachtgevers toe, het moet niet tt vaak voorkomen, als naar onze eigen verzekeringsmaatschappij toe.. ". (Jansen)

De meeste claims komen voort uit aanrijdingen. Die komen regelmatig voor en zorgen voor regelmatig contact met de verzekeringsmaatschappijen. Strikt geno- 
men gaat het hier meestal niet om claims van de opdrachtgevers maar om die van of jegens derden.

Een regelmatig voorkomende categorie problemen betreft de betaling door de opdrachtgever. Hierin volgt ieder zijn eigen aanpak. Een tweetal (Willemse en Thomassen) heeft slechte ervaringen met een incassobureau. De ene - die hoofdzakelijk binnen Nederland transporteert - doet tegenwoordig een beroep op een advocaat (ongeveer tienmaal per jaar). De ander - die vooral internationaal opereert - heeft zich gericht op pro-actief beleid en trekt oninbare vorderingen af van de belasting. Deze ondernemer kiest soms voor een onconventionele oplossing:

"Enkele jaren geleden zijn problemen ontstaan met een Duitse opdrachtgever, eveneens een transportbedrijf. Wij zouden voor deze firma charters rijden voor cen tegenwaarde van $40.000 \mathrm{DM}$. De Duitse firma bleek niet te betalen. Na inschakeling van een Duitse advocaat bleek bij deze debiteur 'officieel' niets te halen (het ging om een notoire failliet). Daarop hebben wij de Duitse firma benaderd voor een (fictieve) opdracht die in Nederland zou moeten worden geladen. De Duitse vrachtauto is na aankomst op ons bedrijfsterrein twee weken vastgehouden om de firma tot betaling te dwingen. Deze betaalde niet, maar ondernam gerechtelijke stappen tegen ons vanwege het vasthouden van de truck. Die zaak loopt nog steeds." (Thomassen)

Anderen hebben een eigen incassotraject en doen zo nodig een beroep op een advocaat of een extern incassobureau. Een enkele keer leiden deze kwesties tot gerechtelijke procedures. Kredietverzekeringen worden naar men zegt niet gebruikt.

\subsection{Concurrenten}

De concurrentieverhoudingen zijn niet van dien aard dat de branchegenoten elkaar naar het leven staan. Wel wordt de branche in de gesprekken gekenschetst als een groep individualisten. Ieder werkt voor zich en zal er niet voor terugschrikken middels onderbieding klanten weg te lokken. De grote opdrachtgevers gaan daar meestal niet op in, maar kunnen het aangrijpen om de prijs bij hun vervoerder omlaag te krijgen (Gerritsen). Een enkeling geeft aan hoe naar zijn inzicht de scherpe prijzen worden mogelijk gemaakt:

$R$ : Aan de andere kant gaat in de branche de mare dat er nogal wat zwart gewerkt wordt. Uren niet uitbetaald, onkostenvergoeding waar mee gesjoemeld wordt. Dat zal best wel gebeuren denk ik. Dan zou je van oneerlijke concurrentie kunnen spreken. Als wij onze mensen op zaterdagmorgen terug laten komen dan moeten we $150 \%$ zaterdaguur betalen, en als ze meer dan 40 uur in de week werken is het $130 \%$. In principe alle gewerkte uren, en dan kun je nog twisten wat zijn wachturen en wat zijn rusturen. Dat zijn van die geijkte dingen in de branche. Als je je 
in principe aan de $C A O$ houdt, dan heb je daar wel eens wat problemen mee. En je hebt concurrentie van België en zo, die op de markt opereren.

I: Ja, als de lonen in Nederland hoger liggen dan in België...

$R$ : De algemene tendens is dat de brutoloonkosten, dan praat ik over lonen plus al. les erbij, dat die in Nederland een stuk hoger liggen dan in België en ook dan in Duitsland. Wij hebben wel eens wat mensen hier die komen van Duitse bedrijven af. Daar hoor je dan van: ze kregen een bepaald bedrag per week en daar deed men het voor. Of je nou 40 uur draaide of vijfig of zestig...je krijgt $700 \mathrm{DM}$ per week punt uit. Volgens Frans Maas zijn de brutoloonkosten in Duitsland $20 \%$ lager dan bij ons. Men zegt wel de Nederlandse chauffeur is de beste van Europa, maar hij is ook de duurste. (Jansen)

Dergelijke kwesties zijn evenwel nooit aanleiding tot claims of gerechtelijke stappen.

\subsection{Resumerend}

In deze branche worde veel zaken gedaan met duurzame relaties, meestal grote opdrachtgevers. En in die relaties bestaat er de mogelijkheid voor routinisering en fine-tuning, in ieder geval in een belangrijk deel van de relaties met de opdrachtgevers. Er wordt door meerdere bedrijven (vier stuks) met een systeem voor kwaliteitsborging gewerkt. Voorts worden veel standaard terugkerende problemen routinematig doorgesluisd naar de verzekeraar. Ook aan de kant van de leveranciers onderhoudt men vaste relaties. Maar men waakt er voor niet al te afhankelijk te worden van één vertrouwd adres.

\section{Hoofdaannemers in de bouwnijverheid}

De bedrijven in de bouwnijverheid hebben enkele specifieke eigenschappen, die deze bedrijfstak scherp doen contrasteren met die van de kunststofverwerking. Kleine en middelgrote bouwbedrijven opereren overwegend regionaal. Dat heeft een logistieke achtergrond. Het is eenvoudig te duur personeel en materiaal over een grote afstand te vervoeren. Bovendien werkt men meestal ook niet grensoverschrijdend in de richting van de buurlanden. Dat heeft vooral te maken met verschillen in regulering, onder meer op het vlak van kwaliteitseisen en aansprakelijkheid.

Een ander belangrijk kenmerk is dat er vooral projectmatig gewerkt wordt. De meeste producten (de seriebouw uitgezonderd) zijn min of meer uniek. Dat stelt beperkingen aan de mogelijkheden de productie te routiniseren en aan de continuilteit van de cliëntèle. De opdrachtgever heeft zijn gebouw en het is niet vanzelf- 
sprekend dat hij daarna nog een ander gebouw nodig heeft. Men moet dan weer zorgen voor nieuwe opdrachten van andere opdrachtgevers. Dat heeft tot gevolg dat planning een hoge mate van onzekerheid kent. Daarnaast is bouw conjuncruur- en seizoengevoelig, wat de productieonzekerheid nog aanzienlijk vergroot.

Bovendien zullen als gevolg van de projectmatige productie de opdrachtgevers vaker wisselen dan in branches waarin de klant een bestendige behoefte heeft aan het voortgebrachte product. Dat sluit de mogelijkheid tot het opbouwen van een bestand van min of meer vaste klanten niet uit, maar beperkt wel de mogelijkheid tot het organiseren van een continue stroom van opdrachten van dezelfde opdrachtgever.

De ongewisheid die de planning kenmerkt wordt gedeeltelijk ondervangen door flexibiliteit ten aanzien van personeel, dat doorgaans naar behoefte wordt betrokken via min of meer gespecialiseerde onderaannemers die per project voor de benodigde metselaars, timmerlieden en voegers zorgen. Daarmee wordt de noodzaak om in tijden van slapte personeel te ontslaan sterk gereduceerd. Deze praktijk brengt - naar nog zal blijken - wel weer andere problemen met zich mee.

Voorts wordt deze sector van de bouwnijverheid gekenmerkt door een nogal scherpe concurrentie. Dit is gevolg van het feit dat bouwwerken steeds meer worden aanbesteed. Dit leidt er toe dat er scherp op prijs wordt geconcurreerd en dat dientengevolge de winstmarges krap zijn. Er moet scherp gecalculeerd worden en daardoor is het niet gemakkelijk tegenvallers flexibel op te vangen of soepel met extra wensen van de opdrachtgever om te gaan.

\subsection{Leveranciers}

Het bouwbedrijf heeft te maken met twee belangrijke categorieën leveranciers: de leveranciers van bouwmaterialen en de onderaannemers. De verhoudingen met deze beide groepen zijn verschillend, onder meer wat betreft de frequentie waarmee zich problemen daarin voordoen. We zullen ze daarom afzonderlijk behandelen.

\section{A) Leveranciers van bouwmaterialen}

Er doen zich naar aanleiding van transacties met leveranciers van bouwmaterialen zelden problemen voor die aanleiding geven tot het nemen van juridische stappen. Alleen bij een groter bedrijf, dat beschikt over een juridische afdeling, kwam het een enkele maal voor dat een leverancier formeel in gebreke werd gesteld in verband met een te late levering of een levering die afwijkt van de afgesproken specificatie. Gerechtelijke stappen zijn een zeldzaamheid.

Ofschoon er zich onvermijdelijk rond geleverde bouwmaterialen onregelmatigheden voordoen, wordt de relatie met deze categorie leveranciers overwegend afgeschilderd als 'probleemloos'. Gedeeltelijk heeft dit te maken met het feit dat 
dergelijke onregelmatigheden niet zeer frequent voorkomen. Daarnaast wordt deze kwalificatie ingegeven door de wijze waarop ze worden afgewikkeld. Onregelmatigheden kunnen worden voorkomen door precieze afspraken en door de selectie van toeleveranciers.

Vooral de grotere bouwbedrijven, die door hun grotere omzet enigszins een inschatting kunnen maken van hun behoefte aan bouwmaterialen, sluiten met leveranciers van materialen, die uit voorraad leverbaar zijn, jaarcontracten waarbij prijsafspraken worden gemaakt over nauwkeurig gespecificeerde materialen. Leveringen vinden plaats op afroep. De kleinere bedrijven hebben veelal te maken met de leveringscondities van de leverancier. Grotere bedrijven hanteren hun eigen inkoopvoorwaarden, tenzij het om zeer grote leveranciers gaat of om leveranties die elders nauwelijks te verkrijgen zijn. Er is bij de grotere bedrijven meestal een vaste kern van toeleveranciers waarmee goede ervaringen bestaan, de ISO-gecertificeerde bedrijven werken met een lijst van 'aanvaarde leveranciers'. Nieuwe leveranciers worden soms door een informatiebureau op hun betrouwbaarheid getoetst, althans wanneer men twijfels heeft. Want over het algemeen kent men de leveranciers wel: iedereen kent iedereen in de bouwwereld, vooral in de buitendiensten.

Kleinere bedrijven volgen niet altijd deze praktijk, met name omdat men zich genoodzaakt ziet de kosten van deze materialen laag te houden:

"En we behouden ons gewoon nog het recht voor om te zeggen nou, zo gauw er even tijd is informeren we ook nog eens naar andere prijzen. Dus je blijf altijd wel met de markt bezig, om te kijken naar de meest gunstige prijs en kwaliteit. Want dat speelt natuurlijk ook een grote rol, want er zijn maar enkele (als we bij hout blijven) enkele goede bedrijven, die goede kwaliteit leveren; en de ene keer doe je weer eens cen half jaartje met dat bedrijf. Over het algemeen blijven wij toch bij het zelfde bedrijf. Kijk, er is toch een bepaalde relatie, die ook weer vele jaren is gegroeid. Maar goed, het moet wel eens een keer, dat we in een directievergadering acggen: hoor eens hier, ga toch maar eens ergens anders informeren van die prijs. Je hebt het gewoon nodig door de kleine mange en de geweldige concurrentie, is het gewoon nodig." (Susteren)."

Overigens melden deze bedrijven met 'wisselende contacten' niet meer problemen dan de andere.

5 Deze werkwijze heeft ook nadelige kanten: "Bij behoorlijke bedragen boven de 5.000 of 10.000 gulden willen we erover praten. Dat is de structuur van het bedrijf. Of dat goed is of niet goed is moeten we in het midden laten. Want het is natuurlijk ook zo, het brengt veel werk mee. Terwijl als je vaste afspraken hebt gaat dat sneller. De verantwoordelijke man zal het altijd moeten afmaken qua prijsvorming. Daar kom je niet onderuit. Terwijl als je een vaste prijs hebt, dan kan iedereen ook in de uitwoering bestellen." 
Problemen doen zich met enige regelmaat voor met betrekking tot levertijden en kwaliteit, in die zin dat de levering afwijkt van de afgesproken specificaties (zoals type tegel, balken, betonijzer e.d.). Dergelijke problemen worden doorgaans geconstateerd middels visuele inspectie op het bouwterrein door de uitvoerder. Meestal kan de uitvoerder zo'n probleem ter plekke afhandelen door aan te geven wat niet in orde is en hoe het kan worden opgelost. Het zijn betrekkelijk 'onproblematische problemen', die routinematig worden afgedaan.

"Ja, daar heb je natuurlijk kwaliteit. Daar hebben we de minste problemen mee eigenlijk. Want meestal is het zo, dat komt op de bouw, die kwaliteit wordt meestal meteen gecontroleerd door de uitvoerder, die meestal ook zo zoals afyesproken is. De prijs is duidelijk afgesproken, daar kan geen verschil in zijn. Hoeveelheid wordt gecontroleerd, dat kan ook geen verschil van mening over zijn. Dus daar heb je eigenlijk de minste problemen mee. Ik durf eigenlijk wel te zeggen: als je ziet wat hier, als ik dat moet inschatten, wat wij inkopen van leveranciers gewoon van materialen (stenen, hout, al die toestanden meer) dan zijn er zeker 10 miljoen op een jaar waar je eigenlijk geen problemen mee hebt. Waar heb je problemen mee? Met de verwerking ervan, met de onderaannemer." (Heerlen)

In een enkel geval werd er melding gemaakt van een structureel probleem in de relatie met leveranciers van bouwmaterialen. Het had betrekking op het levertijden en betrof een bedrijf dat gespecialiseerd was in 'mutatiewerk' (kleinschalige renovatie van woningen). De opdrachtgever verwacht dat de mutatie in korte tijd wordt verricht, maar de materialen worden pas besteld als de opdracht definitief is geworden. De levertijden gaan dan al snel over de oplevertermijn heen. Dit probleem vindt men moeilijk oplosbaar. Een ander bedrijf maakt melding van het feit, dat het een enkele keer voorkomt dat een bepaald product niet geleverd kan worden. In dat geval zegt men zich te beroepen op overmacht.

\section{B) Onderaannemers}

De relatie met de leveranciers van diensten, de onderaannemers, wordt door enkele zegslieden als een bron van problemen afgeschilderd. Een eerste probleem is dat ze niet altijd even precies hun afspraken nakomen. Daarvoor worden verschillende verklaringen gegeven. Sommige vaklieden zijn schaars en laten zich niet gemakkelijk dirigeren. Zo wordt het voorbeeld van de voegers genoemd:

"Nou, met voegersbedrijven, laat ik het zo stellen, het zijn meestal mensen op een bepaald niveau, die weten dat ze ontzettend nodig zijn en daar misbruik van maken. Dat is kort geformuleerd. En daar bedoel ik mee: iedereen weet, na het weekend hebben we maar's maandags op ons werk te zijn. Dat is van een zodanig niveau, en die kunnen zich dat permitteren, om te zeggen ik kom bijvoorbeeld niet. Dan heb je al natuurlijk, dat kan gewoon niet. Als je erop vertrouwt dat die mensen er 's maandags zijn... Het zijn een van de weinige mensen, voegers, die zich dat kunnen permitteren. Als die geen zin hebben dan komen ze niet. Maar als ze ko- 
men zijn ze in staat om 's avonds tot een uur of tien, elf door te werken en dan halen ze het in. Dat zijn van die typische mensen, dat zijn allemaal kleine koninkrijkjes op zich." (Heerlen)

Een andere oorzaak zou zijn dat met name de kleinere bedrijfjes zich met moeite handhaven in het onberekenbare bouwbedrijf. De onzekerheden die de planning van de grotere bedrijven reeds bemoeilijken, gelden a fortiori voor de kleinere bedrijfjes. Als geplande werkzaamheden onverwacht wegvallen lopen de vaste kosten toch door.

"Ik mag wel zeggen, ik loop al zo'n veertig jaar mee, het is ontzettend moeilijk om in de bouw, in een bouwbedrijf, een voegersbedrijf, metselaarsbedrijf, om daar een vaste structuur mee op te bouwen, vaste mensen voor te hebben. Waarom? Je weet gewoon niet wat voor omzet je gaat hebben. Daar komt zoveel op die mensen af, die hebben te doen met die hele bouwwereld, met die lonen, die wekelijks worden be taald, wekelijks alle lasten betalen. Je moet behoorlijke financiële middelen hebben om zo'n bedrijf te kunnen runnen. En ook zo'n voegersbedrijf. Want niet altijd heb je die mensen aan het werk en die moet je toch betalen, en dat is juist het probleem. Terwijl in een ander soort bedrijf weet je wel ongeveer, in mijn automobiel bedrijf bijvoorbeeld, dan wist ik ongeveer: ik krijg zoveel binnen ongeveer, zoveel van de werkplaats, zoveel van het tankstation, en daar kan je een klein beetje de hele zaak op baseren. Dat is moeilijk hier. Ik heb nu een prognose gemaakt voor 1996 voor ons bedrijf. Ik kan rustig zeggen: $90 \%$ van de omzet ligt nou vast. Maar, nou komt het, er zit altijd een klein maartje aan. We weten dat we de opdracht krijgen om een aantal woningen daar en daar te bouwen. Maar stel dat het bij de gemeente stagneert, of dat het ergens anders stagneert, dan loopt bet wit tot oktober. Dan moet je toch van april tot oktober, dan is de hele planning weg. En dat is het vervelende van het geval. In de jaren dat ik in de bouw werk hebben we wel moeilijke jaren gehad, maar over het algemeen hebben we wat geluk gehad. Maar ik ken gevallen van grote bedrijven, waar plotseling een grote klap kwam omdat een bepaald verwachtingpatroon niet gerealiseerd werd. Als jij bijvoorbeeld 100 mensen in dienst hebt en je rekent erop dat je, ik noem maar iets, in april ga je beginnen met leen vakantiepark], dat hier in [de buurt] komt, en je krijgt dat niet en dat is dan een park dat misschien voor 40 of 50 miljoen wordt aangenomen, dan begin maar eens te zeggen hoe je je daar tegenover gaat stellen als je dat niet krijgt. Dat zijn van die dingen, dat is niet niks. Maar dat maakt ook weer het leuke uit van het bedrijf." (Heerlen)

Om dit probleem af te dekken bestaat er de neiging meer werk aan te nemen dan men eigenlijk aankan. De hoofdaannemer die de meeste druk uitoefent wordt dan het eerst bediend. Deze druk kan de vorm aannemen van dreigementen: aanmaningen en aansprakelijk stellen voor de opgelopen vertraging in het werk. Een andere methode is het opbouwen van een goede relatie door persoonlijke contacten en stipte betalingen: 
$R$ : Dus op een gegeven moment, ja je moet er op kunnen vertrouwen, dat die komt. Want die hebben zoveel afspraken gemaakt, die moeten op een gegeven moment gewoon schuiven. En dan bel je op en dan zijn ze niet thuis. En dan krijg je hem aan de lijn en dan krijg je cen heleboel smoesjes, en hij zal komen en dan komt ie de dag daarna toch niet. Dus dan heb je een probleem en dan moet je dus die mensen aansprakelijk stellen. Het beste kan je dan zoveel mogelijk proberen bij een ander te komen die zich wel aan zijn afspraken houdt, maar daar kan je ook hetzelfde mee hebben. Dus het is ontzettend moeilijk. Er zijn, in de bouw heb je nu cenmaal bepaalde figuren, vooral bij de voegers is dat heel erg, tegelzetters en zo, daar moet je een bepaalde relatie mee hebben, dat ze jou prettig vinden om mee zaken te doen, dat ze je niet in de steek laten. Dat is het persoonlijk contact dat zo'n uitvoerder heeft met zo'n man. En wat verwennen door snel te betalen, meer kan je niet doen.

I: Wat zegt $U$ nu..?

R: Snel te betalen. Daar moet je al helemaal voorzichtig mee zijn, kijk ik moet de opdrachtgevers zeggen van aanmanen en zo, dat kan ik me met die mensen niet permitteren. Ik zal heel snel moeten betalen anders komen ze niet. Dat snapt $U$ wel. Als je op een gegeven moment werk doet waar iedereen om staat te springen dan wil die snel betaald krijgen. En als je dat niet doet dan komt ie niet meer. Zo werkt dat nu eenmaal. (Heerlen)

Het is duidelijk dat het opbouwen van een relatie met betrouwbare onderaannemers van groot belang wordt geacht. Naast betrouwbaarheid is ook 'meedenken' van belang. (Gronsveld)

Dit betekent, dat men waar mogelijk selectief te werk gaat bij het inschakelen van onderaannemers. Van de vaste relaties weet men dat ze de capaciteit hebben en kapitaalkrachtig genoeg zijn om het werk uit te voeren. De ISO-gecertificeerde bedrijven hebben een lijst van aanvaarde onderaannemers, die periodiek wordt geëvalueerd. Een firma zei een zwarte lijst bij te houden van onderaannemers waarmee slechte ervaringen zijn opgedaan. Nieuwe onderaannemers laat men soms door een informatiebureau op de genoemde punten screenen. Het komt voor dat, als men niet helemaal zeker van zijn zaak is, financiële risico's worden afgedekt middels een bankgarantie. Daarop kan eventuele schade, bijvoorbeeld ten gevolge van niet of niet tijdig presteren, worden verhaald.

De afspraken met de onderaannemer worden gemaakt op basis van het bestek. Daarin wordt aangegeven wat door hem gemaakt moet worden onder verwijzing naar de door de onderaannemer uitgebrachte offerte. Meestal zijn daarbij tevens de voorwaarden van onderaanneming van de hoofdaannemer van kracht. Schriftelijke explicitering van de afspraken zijn onder meer van belang vanwege de bewijspositie van de hoofdaannemer ten aanzien van de aan de onderaannemer verschuldigde betalingen en daarmee ook ten aanzien van de stortingen op de G-rekening in het kader van de Wet Ketenaansprakelijkheid. 
Middels deze voorzorgsmaatregelen kan de kans op problemen worden gereduceerd. Niettemin kunnen problemen niet helemaal worden voorkomen. Verschillende typen problemen doen zich enkele malen per jaar voor.

\section{Capaciteitsgebrek}

Bij verschillende bedrijven wordt dit type probleem genoemd (Gronsveld, Schinnen, en Heerlen). De repercussies voor het bedrijf van een onderaannemer die het af laat weten wordt geschetst door de zegsman van Schinnen:

"Dan zit je op dat moment met een probleem. Je kunt niet verder. De bouw stagneert. De volgende disciplines lopen vertraging op, iedereen wil verder. Dat betekent vaak dat je bij een ander bedrijf voldoende capaciteit moet zien te krijgen of dat je het contract moet beëindigen met die ene partij en alles moet onderbrengen [bij een ander] met alle kosten van dien. Dat is vrij ingrijpend. "(Schinnen)

Bij Heerlen zet men de onderaannemer dan onder druk door aan te manen en te dreigen met aansprakelijkstelling voor de schade in geval van contractbreuk. Deze aanpak heeft vaak het gewenste effect. Gerechtelijke stappen zijn door deze firma in dergelijke gevallen nog noojt ondernomen. Warom dit niet per se noodzakelijk is wordt duidelijk uit het relaas van Schinnen over de wijze waarop men in geval van contractbreuk te werk gaat:

$R$ : Die [schade] proberen we wel altijd te verhalen. We zeggen: we hebben een bepaalde schade geleden, die proberen we dan in kaart te brengen en die verhalen we dan op de onderaannemer. Dan hebben we het voordeel dat we in dit soort gevallen wel nog facturen achter de hand hebben van die onderaannemer. Dan zeggen we: we houden even die post vast, stellen eerst de schade vast en dan gaan we afrekenen. Op die manier hebben we het wel een beetje in de hand.

I: Gaat dat dan goed op die manier, hoort $U$ daar dan niets meer over, als het op die manier gaat?

$R$ : Vaak wordt dat wel geaccepteerd, zij het na veel morren, want niet iedereen is daar natuurlijk blij mee. Vaak wordt er ook nog wel over geprocedeerd. Maar we hebben toch wel de ervaring dat we dat in de meeste van die gevallen wel winnen. Daar staan we redelijk sterk in. We hebben het dan uiteraard wel goed onderboutd. (Schinnen)

Bij de overige firma's wordt deze categorie problemen niet als zodanig genoemd. Deze bedrijven zeggen veel met vaste onderaannemers te werken, waarbij zich zelden problemen voordoen die niet onderling oplosbaar zijn.

\section{Faillissement}

In geval van faillissement van de onderaannemer heeft de hoofdaannemer een groot probleem met verschillende kanten. In de eerste plaats is het niet eenvoudig om een ander zover te krijgen om het werk van iemand anders af te maken. Bovendien moet dan een nieuwe prijs worden vastgesteld en die pakt meestal hoger 
uit dan de prijs die was afgesproken met de failliete onderaannemer. Door Schinnen wordt dan een concurrente vordering bij de curator ingediend. Twee andere aannemers noemen faillissement vooral in verband met problemen rond de aansprakelijkheid in het kader van de Wet Ketenaansprakelijkheid. Er ontstaat wel eens onenigheid met de curator over de afdracht van verschuldigde premies, waarbij men het gevaar loopt hetzelfde bedrag dubbel te moeten betalen. De zegsman van Heerlen heeft daar slechte ervaringen mee en heeft zijn gedragslijn daarop aangepast:

"...ik heb nu toevallig weer een briefje gekregen van een onderaannemer die failliet is gegaan en die curator heeft mij aangeschreven - en met diezelfde curator heb ik al cens problemen gehad - en die heeft nou... bij de rechter-commissaris gevraagd om verpanding van het bedrag naar de bedrijfsvereniging en de belasting. Als hij dat niet had gedaan dan had ik het weer niet gestort op zijn faillissementsrekening. Want [...] je weet nooit wat er gebeurt met dat geld.

... Je hebt gewoon een juridische aanpak nodig om je gelijk te zoeken daarin. Het is toch van de zotte, dat je op een gegeven moment iemand betaalt en dat die het geld van de G-rekening afhaalt, op een of andere manier, God weet hoe, en dat je later weer zou moeten betalen. Ja, dan weet ik het niet meer."

\subsection{Opdrachtgevers}

Ook de relatie met de opdrachtgever is voor de aannemers een bron van betrekkelijk veel problemen en geschillen, waarin tevens regelmatig juridische stappen worden ondernomen. Overigens wordt wel getracht de kans op problemen te reduceren, maar de mogelijkheden daartoe zijn in deze branche minder ruim dan bijvoorbeeld in de sector van de kunststofverwerking. In deze vergelijking treden enkele in dit verband relevante verschillen naar voren. Over de kwaliteiten van het beoogde product is tussen opdrachtgever en hoofdaannemer blijkbaar meer discussie mogelijk dan tussen de kunststofbewerker en zijn klant. Dergelijke misverstanden kunnen bovendien meestal niet in de loop der tijd uit de weg worden geruimd, zelfs niet met min of meer vaste opdrachtgevers, want elk product is weer anders en kan weer aanleiding zijn tot nieuwe misverstanden. Voorts is er, wanneer met opdrachtgevers een probleem ontstaat, meestal een aanzienlijk bedrag mee gemoeid. Dat laat weinig ruimte voor coulance, zeker niet wanneer de marges erg krap zijn. Tevens lijken de productiefactoren in de kunststofverwerking beter beheersbaar dan in het aannemersbedrijf, waar men te maken heeft met onder meer niet altijd even berekenbare onderaannemers. Tenslotte kan men wat de opdrachtgevers betreft niet al te kieskeurig zijn, omdat men anders het gevaar loopt zonder werk te komen zitten. Anders dan in de kunststofverwerking, waar men een netwerk van bestendige en betrouwbare afnemers kan op- en uitbouwen, 
moet men in het aannemersbedrijf meestal voortdurend nieuwe opdrachten zien te verwerven.

Niettemin doet men in het aannemersbedrijf het mogelijke om problemen te voorkomen. Van diverse kanten werd beklemtoond, dat het schriftelijk vastleggen van afspraken van het grootste belang is. Het belangrijkste document in dit verband is het bestek. Daarin wordt - meestal door de opdrachtgever - gespecificeerd wat er van de uitvoerend aannemer verwacht wordt, vervolgens wordt het werk openbaar aanbesteed of aangeboden aan een of meer aannemers die op basis van het bestek een offerte uitbrengen. Bij het afsluiten van de overeenkomst worden tevens afspraken gemaakt over de prijs en de oplevertermijn. Daarnaast maken meestal ook de standaardvoorwaarden (de Uniforme Administratieve Voorwaarden voor de uitvoering van werken, kortweg UAV) die in de bouw worden gebruikt, deel uit van de bouwovereenkomst. Voor het voorkomen van problemen wordt de kwaliteit van het bestek als het meest belangrijk beschouwd.

"Het cerste stuk van de contractvorm is het bestek. Dat het belangrijkste, dat is vrij uitgebreid. Ik heb het vaak met arbitrages meegemaakt, en dan zie je ook, als je bijvoorbeeld praat over meerwerk - en daar komen we weer terug in de autobranche: als ik tegen $U$ zeg ik maak dat in orde en $U$ krijgt van mij een ruilauto en $U$ krijgt dit en dat, dan is er een mondelinge afspraak. Maar in de bouwwereld kan dat niet. Als ze aan het bouwen zijn en dan komen de opdrachtgevers en die zeggen ik wil dat nog en dat nog, dan zal je die man dat meteen moeten bevestigen, want het kan zijn dat je dan over 10,20,30 of 40 duizend gulden praat. Je praat niet zo over duizend gulden. Dus je zal dat meteen goed moeten bevestigen zoiets. En je moet je akkoord hebben van je opdrachrgever of de directie van de bouw. Dat zijn zaken, dan ben je formeel bezig en je moet je formeel opstellen. Als wij voor de cerste keer samen, $U$ als opdrachtgever en ik als bouwer contact krijgen, op het moment dat we hebben getekend daarna dan moeten we al van het informele af, dan moet ik formeel blijven. In ons beider belang eigenlijk. Want als er iets mis gaat dan moet je ergens op kunnen serugvallen. Het spreekt ook ten dele [vanzelf]. Het is niet zo - om even terug te komen op het autobedrijf-als je het over een accuutje hebt, nou goed daar kom je wel overheen. Maar als er een gebouw staat waar de fundering niet goed van is, dan is de hele bouw niets waard. "(Heerlen)

Er wordt getracht zo expliciet mogelijk afspraken vast te leggen en zonodig wordt naar de op schrift gestelde afspraken verwezen. Precieze formuleringen spelen een cruciale rol bij het voorkomen van onenigheid over de interpretatie van het bestek.

$R$ : Laat ik arggen als wij met een opdrachtgever een afspraak maken: dat moet binnen 230 werkdagen klaar, dan moet er duidelijk in het bestek staan dat je over 230 werkbare dagen praat en niet over kalenderdagen. Ik noem maar iets. Dat is altijd een heel groot item in de boutw: de een wil kalenderdagen en de ander wil werkbare dagen. Kijk, je moet alles goed afspreken. 
I: Er wordt dus veel aandacht besteed aan dat soort precieze formuleringen van condities?

R: Ja, tot in den treure. (Heerlen)

Dat men zich terdege bewust is van de mogelijkheid dat onduidelijkheid aanleiding kan zijn tot een geschil dat kan uitmonden in een arbitrale procedure, blijkt uit het feit dat een bedrijf bestekken soms laat controleren door de juridische dienst van de moedermaatschappij.

"Het kan best zijn dat wij bepaalde zaken niet helemaal begrijpen of dat we het er niet helemaal mee cens zijn. Dan laten we het [bestek] eerst screenen. Dat is ook iets wat de laatste tijd steeds meer naar voren komt, omdat wij zelf hier geen specialisten in huis hebben. Dan zeggen we: jongens, dit is een heel belangrijk stuk, daar zouden problemen uit kunnen voortkomen, omdat het vrij gewichtig is. We laten bet screenen, om te kijken of we het aan kunnen passen. Want je mag best risico's lopen, maar dat moeten weloverwogen risico's zijn. Vandaar dat als wij twijfelen, het wordt doorgespeeld. We kunnen niet alles laten screenen door de juridische dienst. Dat zou teveel werk zijn. " (Eysden)

Wanneer men in zee gaat met grote en bekende opdrachtgevers wordt het inwinnen van informatie over zijn financiële situatie meestal achterwege gelaten. Bij kleinere onbekende opdrachtgevers wordt soms wel informatie ingewonnen, al zijn de ervaringen daarmee niet altijd goed. ${ }^{6}$

De opdrachtgever probeert meestal de financiële risico's van een bouwwerk af te schermen. Het is gebruikelijk dat de opdrachtgever een bankgarantie van de aannemer vraagt. Ook kan de eerste betalingstermijn worden achtergehouden als zekerheid, de zogenaamde inbrengtermijn. De aannemer vindt zijn zekerheid overwegend in de overeengekomen periodieke betaling ('termijnen') naar mate het werk vordert. Blijft betaling achterwege dan is zijn positie niet altijd even gunstig, zoals zal blijken. Een enkele keer worden risico's (als men het niet helemaal vertrouwt) afgedekt met een kredietverzekering, bankgarantie of verdisconteerd in de offerte (door een hogere inschrijvingsprijs).

Er komen in de relatie met de opdrachtgever regelmatig problemen voor. Naast problemen rond de betaling worden er problemen genoemd rond 'meer- en minderwerk' en rond de kwaliteit van (onderdelen van) het bouwwerk. Deze problemen hangen vaak met elkaar samen.

6 Gronsveld is op basis van een positief bericht van de NCM met een opdrachtgever in zee gegaan die door een faillissement het meerwerk niet heeft betaald. Uiteindelijk heeft het bedrijf een anzienlijk verlies moeten nemen. 


\section{Betaling}

Naar verluidt zijn er regelmatig betalingsproblemen, maar daar wordt veelal bij aangetekend dat ze samenhangen met andere problemen zoals over meerwerk of over kwaliteit. Het inhouden van betalingen kan in deze branche, waar een precaire financiële situatie niet uitzonderlijk is, een krachtig drukmiddel zijn om iets van de aannemer gedaan te krijgen. Voor het overige is het voorkomen van betalingsproblemen afhankelijk van het type opdrachtgever waarmee de aannemer te maken heeft. In de utiliteitsbouw, waar meestal grotere instellingen en bedrijven de opdrachtgevers zijn, komen serieuze betalingsproblemen niet vaak voor (tenzij weer in verband met andere problemen). Een dergelijk probleem kan zich voordoen bij een faillissement of wanneer de opdrachtgever (vermoedelijk) krap bij kas zit. In het onderhoudswerk wordt betrekkelijk veel met vaste opdrachtgevers gewerkt, waarmee in de sfeer van de betaling weinig ernstige problemen ontstaan.

Wel gebeurt het regelmatig dat betalingstermijnen worden overschreden. Volgens een zegsman zou dit inherent aan de branche zijn. Soms wordt daarbij een vaste aanpak gevolgd om betaling te bespoedigen.

$R$ : Dat ziin een drietal aanmaningsbrieven die zïir avtouikbeld din in wuant" een beetje verschillen natuurlijk. Na vier weken gaat de eerste, na twee weken geen reactie gaat de tweede, en twee weken daarna gaat de derde. Dat is de procedure. Onderwijl wordt er getracht telefonisch contact op te nemen. En als het probleem dan nog blijft bestaan dan wordt het doorverwezen naar Mr. P. en die neemt het dan van ons over. Maar dat is nog maar éen keer voorgekomen in de tijd dat ik hier werk (6 jaar, AJ). (Susteren)

Opdrachtgevers willen soms wel eens proberen via een klacht betaling wat uit te stellen. ${ }^{7}$ Opvallend is overigens dat voor incassowerk hoofdzakelijk advocaten worden ingeschakeld.

\section{Bestekinterpretatie, meer-en minderwerk, kwaliteit}

De interpretatie van het bestek en meer- en minderwerk (waarmee bedoeld wordt het werk dat aan het bestaande bouwplan tijdens de bouwwerkzaamheden wordt toegevoegd respectievelijk er vanaf gaat) en de kwaliteit van het bouwwerk zijn bronnen van meningsverschillen tussen opdrachtgevers en aannemers. Ze worden hier bij elkaar genomen omdat ze in de praktijk vaak moeilijk te scheiden zijn

7 De zegsman van Schinnen wees daarop: "Wanneer er klachten zijn over de kwaliteit proberen we dat te herstellen. Of als het niet te herstellen is, proberen wij een bepaald bedrag af te spreken, dat wij zeggen: de kwaliteit voldoet niet aan de eisen die gesteld mogen worden, en dan worden er bepaalde kortingen gegeven. Maar dan moet het wel erg duidelijk zijn dat er een kwaliteitsaspect hier een rol in speelt. Vaak wordt dat ook gebruikt door opdrachtgevers om betalingen te vertragen. Dat blijkt dan achteraf dan niet zo te zijn. Maar dan hebben ze een of twee weken extra betalingsruimte." 
of tegelijkertijd een rol spelen. Wat de opdrachtgever als inbegrepen in het bestek beschouwt kan de aannemer als meerwerk zien. En wat de opdrachtgever voor minderwerk houdt kan de aannemer voor overeenkomstig her bestek houden. En misverstanden over het bestek kunnen aanleiding zijn tot meningsverschillen over de kwaliteit van het bouwwerk.

Ondanks het feit dat men zegt veel aandacht te besteden aan de duidelijkheid van het bestek en dat men er op gespitst is alleen tot meerwerk over te gaan wanneer er spijkerharde afspraken over zijn gemaakt met de opdrachtgever, komt het toch regelmatig voor dat er over deze zaken 'discussies' ontstaan. Dat heeft (volgens de zegsman van Sittard) te maken met het feit, dat de administratieve afhandeling van afspraken over meer- of minderwerk enige tijd neemt en de bouw ondertussen doorgaat. Dan kan het zijn dat er meningsverschillen aan het licht komen, wanneer het werk al gedaan is.

Dergelijke geschillen worden betrekkelijk snel (wat men in de literatuur noemt) juridisch 'gethematiseerd', dat wil zeggen in termen van rechten en plichten geherformuleerd. De zegsman van Sittard geeft aan dat als er zich problemen in deze relatie voordoen, door de firma via de juridische afdeling een standpunt wordt ingenomen en dit standpunt wordt dan door de juridische afdeling aan de opdrachtgever meegedeeld. Ook volgens de zegsman van Heerlen wordt bij dit type problemen regelmatig een advocaat ingeschakeld:

"Als je cen probleem hebt, waarvan je denkt dat die man toch wel ten onrechte deze brief heeft geschreven en je meent dat het hem snel duidelijk te maken is, dat hij verkeerd bezig is, maar je wil dat gewoon verwoorden in juridische termen, dan vraag je hem dat even of hij [de advocaat, A]] dat even wil doen. En dan gaat de brief op ons briefpapier terug. Meestal is het dan opgelost. Is dat niet het geval dan schrijfje een brief en dan zeg je: je hoort van mijn advocaat. En dan laat ik hem de adviserende stem daarin over hoe we dat oplossen. [...] Dat is ook zo gevaarlijk met afspraken. Ik merk dat ook, als je een afspraak maakt om dat zo vast te leggen dat bij daar niet op terugkomen. Dat kan je wel zeggen: finale kwijting en weet ik veel. Je moet dat toch goed formuleren en soms zijn het hele kleine dingetjes die je als niet-jurist niet ziet, waar je naderhand toch wel problemen mee krijgt."

Meestal komt men er na verloop van tijd wel samen uit, maar soms loopt het geschil uit op een zaak voor de Raad van Arbitrage. Bijna elk bedrijf heeft in verband met deze kwesties of in verband met geschillen over kwaliteit wel een of meer zaken die in een arbitrageprocedure uitmonden. De ramingen per jaar variëren van 1 tot 3 . Enkele voorbeelden:

"Dat is het geval dat wij om een woningbouwcomplex een tuinmuur moesten bouwen. Een tuinmuur volgens het bestek, daar was een detail van gegeven. Later bleek bij doormeting van de grond, dat die nogal slap van samenstelling was, dus dat je een hele deugdelijke funderingsconstructie - een keerwand constructie - moest maken, die honderdduizend gulden meer zou gaan kosten. Daar had de opdrachtgever 
bij het ontwerp rekening mee moeten houden. Die hebben twee jaar om zo'n project te ontwerpen, ze doen zelf de sonderingsonderzoeken van de grond. Nou, dan moet hij nu niet aankomen dat hij dat niet wil betalen. Het is allang opgeleverd, het project is al opgeleverd enzovoort." (Sittard)

$R$ : Er is eentje [een arbitragezaak, $A]$ ] geweest...daar is een discussie gegaan over de kwaliteit van het geleverde. We moesten een pand verbouwen tot appartementen. De plannen waren door de opdrachtgever naar onze mening vij slecht voorbereid. Het pand bleek...als je gaat verbouwen kun je wel een inschatting doen van de toestand van het geheel, maar je kunt niet achter bepaalde zaken kijken, je kunt niet zien wat achter een muur zit bijvoorbeeld. Je doet een inschatting van het aantal vierkante meters dat je moet stucken... Daar bleek punt een dat de toestand van het pand veel slechter was dan in eerste instantie was aangenomen. Punt twee was de voorbereiding in de zin van de besteksomschrijving en de duidelijkheid omtrent wat men nu eigenlijk precies wilde, die was er niet. Vergunningen waren er niet volledig aanwezig. En dat heefi dan als consequentie dat tijdens de rit er cen aantal kunstgrepen moeten uitgehaald worden om die zaak op een verantwoorde manier op te leveren. Die kunstgrepen hebben ons veel geld gekost, in die zin dat...ja, het op een bepaald moment stilgelegd omdat de vereiste vergunningen niet aanwezig zijm. Dat betekent dus meestal dat wij die kosten dus claimen bij de opdrachtgever. In de praktijk kwam je tegen dat zaken slechter waren dan verondersteld was. We hebben dat hersteld, maar dat heeft weer meerwerk tot gevolg. En je zit in een bepaalde trein waar je mee door moet gaan, tenzij je aan de noodrem trekt, maar dan ligt alles plat. Dus dan probeer je in eerste instantie toch zoveel mogelijk door te gaan, de opdrachtgever is in eerste instantie wel meegaand. Tot het moment dat de rekening komt en dan heb je een probleem. Nou daar zijn wij op gestuit dan, het extra geld dat wij daar naar toe hebben moeten brengen. Daar zijn wij mee naar de Raad voor Arbitrage gegaan. En die heeff geoordeeld dat het plan onvoldoende was voorbereid. En dat dit grotendeels de opdrachtgever te verwijten was. Zo hebben we een gedeelte, maar niet alles, van onze vordering nog hebben [kunnen innen].

I: Als dat soort dingen gebeuren, worden er dan nog nadere specifieke overeenkomsten gemaakt, bijgesteld aan het contract, als je ziet dat er nieuwe onverwachte dingen moeten gebeuren?

$R$ : Nee, aan het hoofdcontract an sich wordt niets bijgesteld. Het is natuurlijk wel zo dat er besprekingen zijn, bouwbesprekingen, waar opdrachtgever en aannemer aanvesig zijn. Daar worden een aantal afspraken....althans dat is de bedoeling dat daar de afspraken keihard gemaakt worden. In dat traject gaat, denk ik, nog wel eens iets mis. Dat men elkaar wederzijds niet bogrijpt, of niet wil begrijpen. (Susteren)

$R$ : Bij én geval loopt een discussie over meer en mindenverk. Er was meerwerk uitgevoerd in mondelinge opdracht van de opdrachtgever. Die betwist dat naderhand 
en stelt dat het in de aanneemsom zit. Dat is een kwestie van: hoe interpreteer je het bestek. (Schinnen)

Toch wordt er voor de stap naar de Raad van Arbitrage een heel traject doorlopen en ook het omstreden belang moet het de moeite en kosten waard maken:

"Als er problemen zijn met betrekking tot de oplevering of de opleveringstermijnen (er kunnen door allerlei omstandigheden, door bijvoorbeeld meerwerk dat de opdrachtgevers in een keer aandragen, kunnen een aantal termijnen niet gehaald worden die men in eerste instantie is overeen gekomen) daar kun je dan achteraf discussies over krijgen van: is het werk nu wel of niet op tijd opgeleverd? Daar wordt in eerste instantie overlegd met de opdrachtgever, met eventuele architecten erbij, of directievoerders. Wij proberen mensen dan te overtuigen dat de termijn waarbinnen we het project hebben opgeleverd en de kwaliteit waarmee het is opgeleverd (daar heb je soms ook nog wel een discussie over) dat het voor de opdrachtgever toch acceptabel is. Het kan zijn dat men daar toch niet uitkomt. En dat de architect c.q. de directievoerder het wel met ons eens kan zijn, maar dat de opdrachtgever toch volhardt in zijn standpunt. En dan proberen we nog een keer een voorstel te doen om uit de impasse te komen. En dat voorstel kan zijn om nog wat vermeende gebreken te herstellen of eventueel als het om kleine vragen gaat om een financiële tegemoetkoming in beperkte mate. Maar als dat niet acceptabel is dan zien wij elkaar voor een arbitragecommissie. Maar dat is een hele lange weg die je dan hebt te gaan en de belangen die daarmee gemoeid zijn moeten ook dusdanig zijn dat zo'n procedure wel verantwoord kan worden gestart. Dat ga je niet voor vijfduizend gulden doen. "(Susteren)

De belangen waarom het gaat zijn vaak echter dermate groot dat het niet gemakkelijk is het met de opdrachtgever op een akkoordje te gooien. Dit is een structurele factor die de kans op een arbitrageprocedure vergroot. Niettemin houdt men voor, maar ook tijdens de arbitrageprocedure de kosten en baten van arbitrage scherp in het vizier. Een volle procedure neemt (naar men zegt) minstens een jaar en is in de ogen van betrokkenen kostbaar. Niet alleen de directe kosten van de procedure tellen daarbij mee, maar ook de advocatenkosten, de kosten van overleg en een eventueel verschijnen voor de commissie. Bovendien kan een aanvankelijk sterk geachte positie bij nader inzien toch minder sterk blijken.

Het komt derhalve regelmatig voor dat lopende de arbitrageprocedure partijen alsnog tot een vergelijk komen:

"Maar het is meestal zo, dat heb ik nu ook ervaren: probeer een arbitrage te vermijden, want het is meestal op het laatst [dat gezegd wordt] laten we maar delen, het is gewoon markthandel. Dan zijn er allerlei technische mensen bij geweest en dat heeft hopen geld gekost. Want dat kost geld. Want als je arbitrage begint moet je al een borg storten. Dat zijn toch mensen die van een dermate niveau zijn [...] die vergoedingen liggen toch op een fl. 150,-per uur. Ze zijn afhankelijk van het be- 
lang met drie of vier arbiters, dat zijn al snel grote bedragen. [...] Ik heb daar van geleerd." (Heerlen)

\subsection{Concurrenten}

Verhoudingsgewijs wordt in deze branche her meest geklaagd over de concurrentieverhoudingen. Er is een tijd geweest dat geïnteresseerde aannemers, in collusie met opdrachtgevers, het werk in onderling overleg verdeelden. Maar de opdrachtgevers en de aannemers zijn voorzichtig geworden. ${ }^{8}$ Dat heeft - naar sommige respondenten beweren - geleid tot bij gelegenheid desperaat gedrag van aannemers die cen tekort aan werk hadden:

"Je hebt in een bedrijf als het onze gewoon een bepaald bedrag nodig waarmee je indirect je kosten moet dekken en dan heb je je winstopslag. Maar als ik u vertel dat eigenlijk de hele aanbestedingsformule normaal vroeger, ieder bouwbedrijf zou ongeveer moeten hebben 7 en $3 \% .7 \%$ dekking van de a.k. (algemene kostendekking) en 3\% winst. Kijk als ik nou 20 mln. omzet dan kan ik hier in die tent voor $1,4 \mathrm{mln}$. mensen plaatsen en andere zaken (computers en personeel) en dan weet ik dat ik voor $20 \mathrm{mln}$. omzet moet binnenhalen om dat te dekken. Dus dat is de cerste vraag. Maar dan wil ik ook nog wat verdienen en dan zou ik uit moeten gaan van de normale problematiek van het bouwbedrij is 7 en 3\%. Maar dat is al jaren niet meer. Als je [het hebt over] aanbesteden en als ik $U$ dan vertel dat sommigen dat doen zonder winst en dan 4 of $5 \%$ maar durven [laten] betalen, anders doen ze helemaal niet mee, dan heb je een idee hoe die concurrentie daar zit. En ik moet zeggen dat als ik zo om me heen kijk, zeker de laatste tijd, dan is dat een heel slechte ontwikkeling. Ik bedoel, het is zo dat daar de hele aanbestedingsproblematiek in de gemeenten op dit moment, door al die publicaties van dat de aannemers teveel hadden geteld, U hebt er misschien wel over gelezen. Dat heefi er toe geleid dat alles via aanbesteding gaat. En als je dan ziet op welke manier en met cijfers sommige mensen inschrijven..." (Heerlen)

I: Is er een vaste kern van opdrachtgevers?

$R:$ Nee, dat is niet meer. Vrocger had je dat wel, toen had je $I$ op 1 verkeer. Bij $Z$ (groot bedrijf) had je mensen waar je goed mee kon spreken... Maar dat is over. Want de concurrentie is moordend geworden en de prijzen kunnen daardoor fink gedrukt worden. Wat doen ze? Ze besteden alles aan. Het steekpenningenverhaal dat kent $U$ ook wel in principe. Dat de mensen bang zijn om beticht te worden dat men steekpenningen heeft aangenomen. Dus een etentje is er ook niet meer bij. Dus men regt: ik wil niet beticht worden. Dus we besteden het aan. [...] Met name in

8 Een verslag van deze praktijken is te vinden in: Dohmen (1996) De vriendenrepubliek. 
Limburg is dat het geval. In het Noorden heb ik begrepen is er nog wat meer 1 op 1 verkeer. Hier is het een ramp wat dat aangaat. Het betekent eigenlijk dat je constant aan het concurreren bent." (Susteren)

Maar men is ook elkaars collega in een sterk regionale branche en er werd wel gezegd dat er samenkomsten werden georganiseerd voor de collega's uit de regio voor de bespreking van gemeenschappelijke kwesties en het onderling contact.

\subsection{Resumerend}

Uit deze opmerkingen blijkt dat voor de kleine bouwbedrijven de mogelijkheid voor het onderhouden van duurzame relaties met opdrachtgevers beperkt is. Niet alleen vanwege de geschiedenis van de bouwschandalen en de reactie daarop, maar ook vanwege het simpele feit dat opdrachtgevers zelden een permanente stroom van opdrachten te vergeven hebben. Daardoor ontbreken hier veelal ook de voordelen van een duurzame relatie: de mogelijkheid tot het opbouwen van vertrouwen, de routinisering van aspecten van de bedrijfsvoering en het voorkomen van problemen. Een gevolg daarvan is dat de relatie met het personeel en de onderaannemers een meer onzeker karakter heeft. Een onzekere planning maakt de relatie met de onderaannemers kwetsbaar. Bovendien is het productieproces in de bouwnijverheid het minst beheersbaar van de drie branches. De afhankelijkheid van de weersomstandigheden vertaalt zich in extra complicaties in de relatie met leveranciers en opdrachtgevers. Deze omstandigheden maken de bouwnijverheid tot een branche die rijk is voorzien van conflictstof. Regelmatig doen zich conflicten voor die soms hoog oplopen en tot juridische stappen leiden. Het is hier meestal niet mogelijk luchthartig over deze kwesties heen te stappen. De bedragen die er mee gemoeid zijn, maken dat voor de aannemer onmogelijk. Het is gebruikelijk zich daarbij tot de Raad voor Arbitrage voor de Bouwnijverheid te wenden. Men geeft aan meestal nog tijdens de procedure door te onderhandelen en regelmatig voor de beslissing tot een compromis te komen.

\section{Eerste conclusies}

Het bovenstaande verslag bevat informatie die van belang is voor verschillende elementen van de vraagstelling. In de eerste plaats wordt er gewag gemaakt van enkele reflexieve methoden voor de afhandeling en preventie van 'storingen in de planning'. Dat zijn de kwaliteitssystemen van de ISO-standaarden en daarnaast is een kwaliteitssysteem van grote opdrachtgevers gesignaleerd. In de tweede plaats wordt duidelijk dat 'duurzame relaties' nog springlevend zijn, ook in internationale bedrijfstakken. Ze blijken echter niet voor alle branches evenzeer tot de mo- 
gelijkheden te behoren. Er is ook iets meer duidelijk geworden hoe dit samenhangt met de omstandigheden waarin de verschillende groepen ondernemers werken.

\subsection{Reflexieve methoden}

Er wordt in de diverse branches het nodige gedaan om problemen in de relaties met leveranciers en klanten te voorkomen. Het selecteren van betrouwbare 'relaties', het opstellen van duidelijke contracten en het uitvoeren van controles behoren tot de gebruikelijke methoden.

De kwaliteitssystemen die werden aangetroffen zijn in dit verband een interessante ontdekking. De ISO-kwaliteitsborging is een betrekkelijk recent verschijnsel, dat bezig lijkt aan een snelle opmars in allerlei sectoren van het bedrijfsleven. De kwaliteitssystemen van grote bedrijven hebben waarschijnlijk al een langere geschiedenis.

\section{ISO-kwaliteitszorg}

De ISO-standaarden die ik aantrof behoren voornamelijk tot wat de ISO-9000 serie genoemd wordt. Deze standaard is gericht op het 'borgen' (vasthouden) van de kwaliteitscontrole van het productieproces die al in het bedrijf wordt gehanteerd. Het is bedoeld als een opstap naar 'Total Quality Management' (de zogenaamde ISO-14000 standaard, die door enkele bedrijven wordt aangehaald), een systeem dat naast het productieproces ook nog de werkomstandigheden en het milieu bestrijkt.

Het is een controlesysteem, waarin in feite de traditionele preventicinstrumenten (zoals selectie, contract en controles van het productieproces) zijn samen gebracht en geordend. Wat er apart aan is, is het nadrukkelijk reflexieve karakter ervan. Het is de bedoeling dat van fouten wordt geleerd. Daarvoor is het nodig dat ze geregistreerd worden, zodat ze geanalyseerd kunnen worden om er voor de organisatic een les uit te trekken zijn. Ook tussen de 'relaties' kan zo'n registratiesysteem dienen als informatiebron voor het evalueren en scherpstellen van de relatie. Alle activiteiten die met een dergelijk systeem verband houden worden vastgelegd in het 'kwaliteitshandbock'.

Kwalteitszorg is erop gericht een bedrijfsorganisatie te creëren die garant staat voor het permanent voldoen aan een bepaalde kwaliteitsstandaard. ${ }^{10} \mathrm{Al}$ deze in-

9 Over de krachten achter die opmars: Jetringhoff (1997) Een grval sun aelfregulering

10 Er worden verschillende invullingen van het begrip 'kwaliteit' gehanteend. Er bestaat blijkbaar geen algemeen geldige definitic. Een veelgebruikte omschrijving is: het leveren van een product met een constante kwaliteit overeenkomstig de wensen van de klant. Gijsbers \& Romme (1996) 
spanningen zijn erop gericht 'klanttevredenheid' te behouden door het voorkomen van afwijkingen van het product van de overeengekomen specifcaties in alle fasen van de productie. ${ }^{11}$

Het installeren en onderhouden van een systeem van kwaliteitszorg is een tijdrovend en duur proces. Ook de kwaliteitssystemen worden getoetst en wel door certificerende instellingen, die het hele proces tegen vergoeding begeleiden en na een succesvolle afronding belonen met een diploma, het ISO-certificaat. Dergelijke instellingen verzorgen ook de controle: met enige regelmaat worden bedrijven bezocht voor een 'audit'. Het is dan de bedoeling dat wordt nagegaan of alle registratiesystemen wel aantoonbaar naar behoren functioneren, en of er naar aanleiding van de registraties actie is ondernomen.

Uit de interviews is op te maken dat het ISO-certificaat al een redelijke verspreiding had, zeker onder de grotere ondernemingen. ${ }^{12}$ De redenen die men angeeft voor de stap naar een kwaliteitssysteem zijn divers. Sommigen zijn duidelijk enthousiast over de mogelijkheden om ook daadwerkelijk kosten te bespaten en de klanten tevreden te stellen. Dit zijn de enthousiasten. Anderen zien het meer als iets dat er in de branche bij hoort. $\mathrm{Zij}$ passen zich aan. Enkele respondenten gaven te kennen dat ze door hun grote opdrachtgevers voor het blok waren gezet: óf een kwaliteitssysteem óf geen opdrachten meer. Volgens onderzoek zijn er ook nog bedrijven die een certificaat als een middel zien om zich te profileren uitsluitend om hun marktaandeel te vergroten. ${ }^{13}$ Deze laatstgenoemde motieven doen twijfels rijzen over wat een ISO-certificaat eigenlijk garandeert. Het is duidelijk dat de grote opdrachtgevers een belangrijke rol spelen in de verspreiding van de ISO-standaard. Maar daar is niet noodzakelijk mee gezegd dat ze meer krijgen dan gecertificeerde toeleveranciers. Voor de kwaliteit van een kwaliteitssysteem lijkt de inzet van de onderneming zelf van doorslaggevend belang.

\section{Bedrijfsspecifieke kwaliteitssystemen}

Ook nog op een andere manier kunnen grote opdrachtgevers de toon aangeven ten aanzien van de kwaliteit. Dat gebeurt soms door het hanteren van bedrijfsspecifieke kwaliteitssystemen. Zulke systemen zijn typisch door een groot concern

\section{ISO-certificatie als opstap naar TQM?, p. 374}

11 Zie voor een verdere beschrijving van aspecten van ISO-kwaliteitsborging: Jettinghoff (1997) t.a.p., p. 55 c.v.

12 De Kwaliteitsdienst Industrie (KDI) te Rotterdam registreert de certificering in ons land. Volgens de opgave van deze dienst gaven de tellingen van begin 1997 aan dat ongeveer 6.500 ISO-certificaten waren verleend. Dat is cen flink aantal, maar dekt in kwantitatief opricht toch slechts een beperkt deel van het totale aantal bedrijven.

13 Zwetsloot en Sprengers (1992) Op zoek naar synergie, p. 18) 
ontworpen om te garanderen dat alle toeleveranciers van dit bedrijf hun uiterste best doen om precies te leveren wat de opdrachtgever verlangt, zodat het de opdrachtgever in kwestie mogelijk is om bijvoorbeeld een 'zero default' standaard te verwezenlijken. Een voorbeeld wordt genoemd door Rubber en naar zijn zeggen zijn deze kwaliteitssystemen aanzienlijk meer veeleisend dan wat een ISOcertificaat aan standaarden meebrengt.

\subsection{Duurzame relaties}

Het lijkt er op dat de duurzame relaties, die Macaulay in de zestiger jaren heeft gesignaleerd, ook in de huidige internationaliserende economie (anders dan Galanter en Rogers aan het eind van de jaren ' 80 veronderstelden) voortbestaan en mogelijk zelfs in sterkere mate dan voorheen. De onderzoeksresultaten sluiten wat dat betreft goed aan bij macro-analyses. Volgens het overzicht dat Castells van deze literatuur geeft, heeft de economische herstructurering, die in de jaren ' 80 is ingezet, geleid tot enkele ingrijpende organisatorische veranderingen in grote ondernemingen die in dit verband van belang zijn. ${ }^{14}$ In de eerste plaats heeft de grote, verticaal geïntegreerde onderneming plaats gemaakt voor een kernonderneming die op grote schaal werk uitbesteedt aan een stabiel netwerk van kleine en middelgrote ondernemingen. Het gaat om een op de Japanse automobielindustrie geinspireerd model, waarin planningsconformiteit hoog in het vaandel staat. ${ }^{15}$ Elementen van dit patroon zijn duidelijk herkenbaar bij enkele ondernemingen in de kunststofverwerking. Daarbij bleek ook dat deze kleinere bedrijven meestal participeerden in de netwerken van verscheidene internationale ondernemingen, een andere ontwikkeling die Castells signaleert. En tenslotte wijst hij op de vervlechting van de grote ondernemingen in strategische allianties. Dergelijke allianties zijn vooral ontstaan als methode om de torenhoge ontwikkelingskosten in de high-tech sector te kunnen dragen. Deze allianties zijn specifiek voor bepaalde markten, producten en processen en sluiten concurrentie voor het overige (de niet door de alliantie gedekte activiteiten) zeker niet uit. Castells concludeert, dat de grote onderneming niet langer meer in zelfgenoegzaamheid kan opereren:

"Their actual operations are conducted with other firms: not only with the bundreds or thousands of subcontracting and ancillary enterprises, but with the dozens

14 Castells (1996) The rise of the network society, vol. 1, p. 152 e.v.

15 Dit wordt kernachtig samengevat met de slogan "five zero's": zero defect in the parts, zero mischief in the machines, zero inventory, zero delay, zero paperwork. Ibid., p. 158. Over de Amerikaanse automobiel-industrie: Kenworthy, Macaulay en Rogers (1996) "The more thing change: 
of relatively equal partners with whom they cooperate and compete at the same time in this new brave economic world where friends and foes are the same. "it Maar ook blijkt dat niet alle bedrijfstakken op deze leest zijn geschoeid. Dat is zeer evident in de bouwnijverheid. Het is aannemelijk dat het met name de aard van het product is die het onderhouden van vaste relaties bemoeilijkt.

\subsection{Klachten, geschillen en juridische stappen}

De frequentie waarmee zich in de relaties met toeleveranciers en klanten storingen en geschillen voordoen lijkt per branche te verschillen. De kunststofverwerkende bedrijven zijn relatief storingsarm. Over elke gesignaleerde storing wordt in beginsel geklaagd bij de relatie om klachtpreventie mogelijk te maken. Bij de hoofdaannemers komen storingen verhoudingsgewijs veel voor. De wegtransporteurs nemen in dit opzicht een middenpositie in. Voor deze verschillen zijn enkele mogelijke oorzaken aanwijsbaar. Het gaat om een complex van omstandigheden die samen de typische 'logica van het ondernemen' in een bepaalde bedrijfstak vormen.

De kunststofverwerkers zijn productiebedrijven, die hun product aan een aantal vaste afnemers afzetten. In deze relaties kunnen de werkwijzen in de loop der tijd steeds beter op elkaar afgestemd worden. Deze afnemers zijn bovendien gewend hun hoge eisen gehonoreerd te krijgen. Ten slotte is het productieproces in deze branche bijna volledig afgesloten en dus niet toegankelijk voor contingente invloeden. In de bouwnijverheid treffen we een tegengestelde situatie. Er wordt meestal projectmatig geproduceerd, het product is een unicum. De opdrachtgevers hebben zelden een vaste stroom opdrachten te vergeven. En het productieproces speelt zich grotendeels in de open lucht af, met alle storingsmogelijkheden van dien. Het wegvervoer heeft de combinatie van vaste opdrachtgevers en open productieprocessen.

De hantering van klachten en geschillen is onder invloed van deze omstandigheden ook verschillend. De kuststofverwerkers krijgen weinig met problematische klachten te maken en als zich klachten voordoen hebben beide partijen, gerien het belang van hun relatie, er alle belang bij de kwestie in der minne te schikken. In deze context is het doen van juridische stappen een zeldzaamheid. Bij de hoofdaannemers komen problematische klachten regelmatig voor, ook aan de kant van de opdrachtgevers. In deze relaties is er geen vaste verhouding die als extra prikkel kan fungeren om te trachten er samen uit te komen. Hier is meestal de omvang van het omstreden bedrag de stimulans om (vooral spoedig) tot een vergelijk te komen. 


\section{BIJLAGE: Profielen van Nederlandse bedrijven}

\section{Kunststofuerwerking}

Summer is een klein bedrijf met 28 werknemers. Het is een dochteronderneming van een bouwbedrijf. De firma fabriceert gevelelementen. De gebruikte kunststofprofielen worden hoofdzakelijk bij één leverancier ingekocht. De onderneming levert zowel aan de particuliere als de publieke sector.

Pellet is ook een klein bedrijf met 28 werknemers. Het is de Nederlandse vestiging van een onderneming die is gespecialiseerd in het malen en recyclen van kunststof. Meestal gaat het om 'loonmaling', waarbij de klant zelf de kuststof aanlevert. Het bedrijf is ISO-gecertificeerd.

Korrel heeft 70 werknemers, waarvan ongeveer een derde op uitzendbasis. Ook dit bedrijf bewerkt kunststof, voor eigen rekening of voor derden die de kunststof zelf aanleveren. Het is een joint venture van enkele Aziatische chemiereuzen. Veel opdrachten lopen via deze moederbedrijven. De firma heeft een ISO-certificaat.

Compound heeft bijna 100 werknemers in dienst en is een geheel zelfstandig bedrijf. De onderneming fabriceert grote kunststofproducten. De toeleveranciers zijn de grote kunststofproducenten. Het bedrijf exporteert het grootste deel van de productic naar klanten in diverse Europese landen. Het bedrijf is ISO-gecertificeerd.

Folie is een bedrijf met 167 werknemers. Het produceert kuststoffolie en is een productiefaciliteit van een een petrochemische multinational. De afnemers zijn bedrijven uit de verpakkingsindustric in Europa. De productie en verkoop worden centraal aangestuurd. Het bedrijf is ISO-gecertificeerd.

Rubber heeft ongeveer 500 werknemers, waarvan 100 uitzendkrachten. Het bedrijf is de Europese vestiging van een internationaal bedrijf met vestigingen Aziě en de Verenigde Staten. De onderneming fabriceert onderdelen voor randapparatuur van computers en levert aan de grote merken. De leveranciers zijn de grote Europese chemieconcerns. Het bedrijf is ISO-gecertificeerd.

\section{Wegtransport}

Willemse is een klein familiebedrijf met 17 werknemers. De onderneming vervoert vooral afvalproducten voornamelijk in de regio. Er wordt niet in het buitenland gewerkt.

Gerritsen heeft 40 werknemers in dienst. De onderneming is actief in het internationaal transport, onder meer van stukgoed, gevaarlijke stoffen en bouwma- 
teriaal. De bestemmingen liggen overal in Europa, maar vooral in Spanje. De onderneming is ISO-gecertificeerd.

Pietersen is een klein familiebedrijf met $\mathbf{4 2}$ werknemers in dienst. Het bedrijf is gericht op internationaal transport, in het bijzonder groupagevervoer (gepalletiseerde vrachten). Er wordt vooral gereden op Spanje. De onderneming is ISO-gecertificeerd.

Jansen heeft 70 personeelsleden in dienst. De onderneming is actief in het zeecontainervervoer, vanuit grote havens in Nederland en België naar allerlei bestemmingen in Europa. Er wordt voornamelijk gewerkt voor een klein aantal grote opdrachtgevers. Het bedrijf is ISO-gecertificeerd.

Thomassen is een internationaal transportbedrijf met 80 werknemers. Het bedrijf heeft ook nog een vestiging in Frankrijk. Naast transport is de onderneming actief in overslag en ompakken. Bestemmingen liggen vooral in West Europa. Het merendeel van de opdrachtgevers zijn vaste klanten. Het bedrijf is ISO-gecertificeerd.

Hendrikse is een grote onderneming met 300 werknemers. Het bedrijf is ondergebracht in een holding, samen met een vrachtwagendealerschap. Het is actief in het internationaal transport, met bestemmingen in West en Oost Europa. Het bedrijf is ISO-gecertificeerd.

\section{Bouwnijverheid}

(N.B.: de plaatsnamen verwijzen niet naar de werkelijke plaats van vestiging van het bedrijf)

Gronsveld is een kleine aannemer met 15 medewerkers. Het bedrijf was aanvankelijk een familiebedrijf maar is onlangs overgenomen. Nu is het een zelfstandige werkmaatschappij van een grotere onderneming. Men is actief in de verbouw en renovatie in de sectoren woningen en utiliteit. Er zijn vooral institutionele opdrachtgevers en daarnaast nog wat werk voor particulieren. De actieradius is Zuid-Limburg.

Susteren is een kleine aannemer met 40 werknemers. Ook dit is een oud familiebedrijf dat enkele jaren geleden bij gebrek aan opvolging aan een grote bouwonderneming is verkocht. Ook dit bedrijf is een zelfstandige werkmaatschappij. De bouwactiviteiten betreffen de utiliteitsbouw, groot onderhoud, restauratic en renovatie. Het werkgebied is Heerlen en omgeving.

Heerlen is een middelgrote hoofdaannemer met 56 werknemers. De onderneming is voor een deel het eigendom van een andere onderneming. Er wordt gebouwd in de sectoren woningbouw en utiliteitsbouw. De opdrachtgevers zijn de overheid, woningbouwcorporaties en beleggers. Er wordt weinig voor particulieren gewerkt. Het werkgebied is Zuid-Limburg. 
Schinnen is een middelgrote hoofdaannemer met 70 werknemers. De onderneming is ondergebracht in een holding, samen met nog diverse andere bouwbedrijven. De activiteiten richten zich op Zuid-Limburg. De firma is actief in de woningbouw, de utiliteitsbouw, onderhoud en projectontwikkeling.

Eysden is een middelgrote hoofdaannemer met een sterk in omvang fluctue rend personeelsbestand dat zich rond de 100 medewerkers beweegt. Ook dit was een familiebedrijf dat reeds geruime tijd geleden ten prooi is gevallen aan de schaalvergroting en is opgekocht door een groot bouwconcern. Een voormalig bedrijfsonderdeel is in België actief. De firma heeft projecten in de utiliteitsbouw, woningbouw, en weg- en waterbouw.

Sittard is ook een middelgrote bouwonderneming met ongeveer 200 medewerkers. Ook dit voormalige familiebedrijf is een onderdeel geworden van een groot bouwconcern. Binnen het moederbedrijf is het weer een onderdeel van een zelfstandige werkmaatschappij met diverse vestigingen in Nederland. De onderneming is actief in de sectoren woningbouw, utiliteitsbouw en projectontwikkeling. 


\section{HOOFDSTUK 5}

\section{De invloed van de juridische infrastructuur:}

\section{een grensoverschrijdend perspectief}

Een centrale vraag in dit vergelijkend onderzoek heeft betrekking op de relatie tussen het gebruik van reflexieve methoden ten aanzien van het afhandelen en voorkomen van klachten en conflicten enerzijds en variatie in de geboden justitiële faciliteiten. De achterliggende gedachte was dat wanneer die faciliteiten beperkt zijn (zaken)mensen de juridische weg mijden en andere wegen inslaan: ze bezinnen zich op mogelijkheden om klachten en conflicten te voorkomen of zullen meer geneigd zijn compromissen te sluiten of het erbij laten zitten als er conflicten ontstaan. En omgekeerd: als de faciliteiten royaler zijn zal de juridische weg minder gemeden worden en is het ook niet zo nodig werk te maken van het voorkomen van klachten en het sluiten van compromissen.

De Duitse juridisch-infrastructurele context voor het doen (of vermijden) van (civielrechtelijke) juridische stappen is globaal gekenschetst als toegankelijker (goedkoper en sneller) dan die in Nederland. De Belgische context biedt in ieder geval een duidelijk minder snelle behandeling van geschillen

Als de beschreven gedachtegang klopt zullen we bij de Duitse bedrijven indicaties van het volgende kunnen waarnemen:

1. er wordt minder belang gehecht aan en werk gemaakt van de preventie van klachten en het vermijden en beëindigen van conflicten in genoemde relaties. 2. er worden vaker juridische en gerechtelijke stappen ondernomen inzake (in de relatie met leveranciers, klanten en concurrenten gerezen) klachten en conflicten. Bij de Belgische bedrijven zou een omgekeerd patroon waarneembaar moeten zijn.

We zullen deze vragen benaderen vertrekkend vanuit de gegevenheden van het sociale veld waarin de ondernemer werkt en nagaan waarom vanuit die positie het voorkomen van problemen wenselijk en mogelijk is, hoe met gerezen proble- 
men wordt omgegaan en in hoeverre daarin de invloed van de kwaliteiten van de juridische infrastructuur te beluisteren valt.

\section{Kunststofverwerking in Duitsland en België: van eenzelfde laken.}

Om degenen ter wille te zijn die tevreden zijn met de grote lijn volgen hier alvast de belangrijkste conclusies voor deze sector. In de eerste plaats zijn de inspanningen die in deze bedrijfstak worden gedaan om klachten en geschillen te voorkomen in geen van de drie landen aanwijsbaar ingegeven door kenmerken van de juridische infrastructuur. De relatie met de klanten en vooral het behouden van die relatie vormt duidelijk het overheersende motief. In de tweede plaats lijken de bedrijven in deze branche er in elk van de drie landen in geslaagd het aantal klachten die aanleiding zouden kunnen zijn tot geschillen, in hoge mate te beheersen en voor het overige volgens routines of in overleg op te lossen. Het gevolg is dat geschillen in de commerciële relaties betrekkelijk zeldzaam zijn en het ondernemen van juridische stappen hoogst zelden overwogen wordt. Er zijn in dit opzicht geen merkbare verschillen waar te nemen tussen de bedrijven uit de verschillende landen. Het streven naar klanttevredenheid is niet gebaseerd op goedgunstigheid van de kunststofverwerkers, maar is een standaard in hun branche. Deze standaard wordt vooral gedefinieerd binnen (soms wereldomspannende) industriële netwerken waarin verschillende van de kunststofverwerkende bedrijven participeren. In de volgende paragrafen passeren enkele illustratieve voorbeelden van dergelijke netwerken de revue. Het gaat in deze bedrijfstak, ook in België en Duitsland, vooral om productienetwerken. In deze netwerken wordt een belangrijke rol gespeeld door de bedrijven die op de overgang tussen productie en distributie gesitueerd zijn. Een Nederlands voorbeeld de fabrikanten van kantoormachines, de opdrachtgevers van de firma Rubber, is in het vorige hoofdstuk beschreven. Hierna zullen onder meer fabrikanten van auto's en levensmiddelen voor het voetlicht treden. Uiteindelijk zijn zij het die de kwaliteitseisen voor het netwerk formuleren, uiteraard uitgaande van wat technisch mogelijk is. De toeleveranciers - zoals de bedrijven die hier aan het woord komen - verplichten zich de organisatie van de onderneming zo in te richten dat het nakomen van deze standaarden zo goed mogelijk gewaarborgd is. Zo ontstaat een soort gelede productiemachinerie waarin alles in het werk wordt gesteld fricties te voorkomen en de transactiekosten zo laag mogelijk te houden.

In deze relaties wordt derhalve aan beide kanten veel geïnvesteerd en ze kunnen mede daardoor vrij complex worden, in de zin dat er een aanzienlijke verwevenheid en verbondenheid (en daarmee afhankelijkheid) kan ontstaan. Daarvan 
biedt het volgende nog enkele aardige voorbeelden. Dergelijke betrekkingen worden met het oog op de langere termijn opgebouwd, als en zolang de klant tevreden kan worden gesteld. Dat is ook tegelijk het doel van het streven naar klanttevredenheid: het verwerven en behouden van de 'vaste' klandizie van deze en dergelijke 'toonaangevende' bedrijven. Klachten dienen in een dergelijke organisatie niet of nauwelijks voor te komen en als ze optreden moet dat aanleiding zijn tot het treffen van preventieve maatregelen. De klachten zelf kunnen dan in onderling overleg worden afgehandeld. De methoden van preventie van klachten en klachtenbehandeling zijn grotendeels hetzelfde als die bij de Nederlandse collega's zijn gesignaleerd. En ook de condities die een dergelijke werkwijze succesvol helpen maken zijn in wezen gelijk.

\subsection{Leveranciers}

\subsubsection{Preventie van klachten}

Evenals in Nederland beklemtonen mijn Duitse en Belgische zegslieden dat zich in deze branche met de leveranciers vrijwel geen fricties voordoen. Geen van de bedrijven heeft gedurende de afgelopen drie jaar in de relatie met een leverancier met een gerechtelijke procedure te maken gekregen.

In Nederland bleken een aantal werkwijzen daarbij een belangrijke rol te spelen. In de eerste plaats speelde een rol dat er zowel aan de inkoop- als aan de verkoopzijde veel zaken gedaan werd met grote ondernemingen, vaak ook in bestendige en complexe relaties. Voorts bleken goede schriftelijke afspraken over essentiële zaken van belang geacht te worden. In sommige gevallen waren controles van levering belangrijk. En met name in deze branche bleek bij enkele bedrijven het fenomeen 'kwaliteitssysteem' al deze elementen te omvatten en het streven naar het reduceren van klachten te integreren in alle relevante onderdelen van het productieproces. Ook bij de Duitse en Belgische kunststofverwerkers blijken deze elementen een rol te spelen.

\section{A) Selectie: internationale grondstoffenleveranciers en duurzame relaties}

Het vrijwel frictieloze karakter van deze betrekkingen is voor een deel een uitvloeisel van het feit dat de leveranciers veelal grote en goed georganiseerde bedrijven zijn waarmee reeds jaren zaken worden gedaan. In deze branche is een belangrijk gegeven dat de aanbodzijde van de markt voor de chemische grondstoffen die de Duitse en Belgische (net als de Nederlandse) bedrijven inkopen, bestaat uit een beperkt aantal internationaal opererende, grote Westerse concerns. Dat kan nadelen hebben (bijvoorbeeld wat betreft de prijsstelling), maar ook voordelen. 
Een van de voordelen is dat deze bedrijven naar verluidt: "...technisch van een zo hoog niveau [zijn] dat het voor ons probleemloos verloopt." (Flasche, D) Bij dit bedrijf speelt ondermeer een rol dat de producten die worden geleverd gestandaardiseerd zijn en dienovereenkomstig voorzien van een certificaat. De technische kwaliteit van de leveringen is blijkbaar zo betrouwbaar, dat soms niet in een controle vooraf is voorzien.

"Je moet het ook zo zien: als je voor automotive werkt is de leverancierskring waarin je kunt kopen beperkt. Dus meestal is zo'n kunststofstuk mee ontwikkeld door de materialenleverancier die samen met ons en onze eindklant bepaald heeft aan wel. ke specificaties die grondstoffen moeten voldoen. [...] Dus meestal hebben wij niet meer dan twee of drie bronnen waar wijgrondstof kunnen kopen voor een bepaald product en vaak maar een. "(Parts, B)

Zowel Duitse als Belgische bedrijven zijn dus selectief op grond van kwaliteitsoverwegingen:

[Zijn er nog andere motieven om vaste relaties te onderhouden?] "Daar is eerstens de kwaliteit. We zouden ook elders kunnen inkopen, in China bijvoorbeeld. Maar dat doen wij niet want het prijsverschil is niet zodanig groot dat men het risico wil aanvaarden dat de kwaliteit niet in orde is. Wij kunnen de grondstoffen hier niet analyseren voor ze in de productie gaan. We zien de kwaliteit pas bij de productie. Van de grote jongens met het certificaat kan ik er van verzekerd zijn dat de grond. stof aan de specificaties voldoet. Eigen onderzoek zou te kostbaar zijn omdat het technisch zeer moeilijk is. Bovendien zijn onze eindprijzen te laag om dat te kunnen bekostigen. Vandaar dat we de voorkeur geven aan de grote producenten." (Flasche, D)

Een leverancier die de juiste kwaliteit levert, bespaart onnodige inspanning en voorkomt veel problemen.

"Je kent hun producten, zij kennen onze behoeften. Het is telkens een probleem bij een nieune leverancier om te krijgen wat je nodig hebt. Dat is niet zo eenvoudig." (Thermo, D)

"Er is ook enige vorm van samenwerking. Misschien een groot woord. Maar in onze branche is het niet zo dat je zomaar een product koopt. Je kunt dat ook doen in Korea. We doen dat niet omdat het investeringsgoederen zijn. Je bent er venantwoordelijk voor, je moet een beetje ingedekt zijn naar de kwaliteit toe. Je kunt niet zomaar op de hoek van de straat wat gaan kopen. Dat is goed voor kunststof dat nadien in de vuilbak belandt. Maar bij ons is dat niet $20 . "$ (Kist, B)

1 De zegsman van Kist specificeert later in het gesprek de eisen die aan de kratten worden gesteld: "Er gaan zeven lagen op een pallet, drie pallets op elkaar. De onderste moet dus drieduizend kilo dragen. Dus heel het concept van uw krat is darop gebouwd. Met als gevolg dat ze oersterk zijn." en "Wat voor ons van belang is is de UV-stabiliteit. Rood blijft rood, over zes jaar is dat nog dezelfde tint." 
Deze relaties zijn overigens meestal niet exclusief: men onderhoudt graag enkele alternatieve relaties, met name met het oog op de prijs en de leveringszekerheid. Dat geldt niet alleen voor de grote chemiereuzen maar vaak ook voor de leveranciers van andere benodigdheden.

"Wij hebben alternatieve leveranciers. Wij hebben hofleveranciers, maar we hebben twee of drie alternatieve leveranciers. We sluiten raamcontracten af met twee leveranciers: enerzijds om zekerheid te hebben, anderzijds om een gunstige prijs te krijgen." (Schaum, D)

"De centrale inkoop wordt o.m. gedaan om zeker te stellen dat de dochterondernemingen voorzien zijn. Op dat vlak waren wel problemen. Dat is het eerst voorgekomen tijdens de oliecrisis van 1973. Er kan mij niets ergers overkomen dan dat ik geen grondstoffen meer heb. Daarom kopen wij ook bij iedereen in grote hoeveelheden zodat we relatief zeker zijn van toevoer. Wat de prijs betreft zijn ze allemaal gelijk." (Flasche, B)

Zoals ook bij een Nederlands bedrijf het geval bleek, bemoeit de klant zich soms ook met de keuze van leveranciers, hetzij uit bezorgdheid om de kwaliteit ("die zeggen dan: geen Russisch materiaal gebruiken." Kist, B), hetzij om redenen van (waarschijnlijk) leveringszekerheid - over het hoofd van hun toeleverancier heen:

"...wat je vaak ziet is dat elke autoconstructeur ermee gebaat is om er voor te zorgen dat er in zijn auto's (zijn range) alle kunststofleveranciers wel eens aan bod komen. Dat er van onze klanten een aanbeveling komt van: ga maar bij Piet kopen, want wij hebben met Piet een afspraak dat hij voor $20 \%$ van de bumpers levert. [Dat gebeurt ook meestal?'] Ja, dat is een eis die ze stellen. Vaak gebeurt het dat op de eindtekening gespecificeerd wordt welke grondstofleverancier... "(Parts, B)

\section{B) Partnerschap}

Dat er vaak duurzame relaties bestaan is geen toevallig gegeven, maar iets dat om verschillende redenen actief wordt nagestreefd. Dat men duurzame relaties op prijs stelt komt overigens maar gedeeltelijk voort uit de wens om expliciete afspraken nagekomen te zien. Met name uit de gesprekken in Duitsland en België in deze branche kwam naar voren dat duurzame betrekkingen blijkbaar nog andere aantrekkelijke kanten kunnen hebben dan kwaliteit en zekerheid van belevering. Men zoekt 'partners'.

Verschillende respondenten, zowel Duitse als Belgische, geven uitdrukkelijk te verstaan dat men van een duurzame relatie meer verwacht dan het naar de letter uitvoeren van wat is afgesproken. De klant verwacht soms blijkbaar ook een zekere solidariteit van zijn leverancier wanneer hij door onvoorziene omstandigheden in het nauw wordt gedreven. Het gaat dan vooral om 'flexibiliteit' die men verwacht van de partner. Als men onder prestatiedruk staat wordt van de vaste relatie een extra inspanning verwacht. Als men onder margedruk staat geldt hetzelfde. 
De 'partner-leverancier' wordt verondersteld tot op zekere hoogte mee te denken en mee te werken met zijn 'goede klant'.

"We kennen de organisatie, we kennen de kwaliteit. Hij ziet ons als partner omdat we al zolang samenwerken. Gemeenschappelijk probleemoplossing, dat loopt ved beter. Hij levert ook zaken waar hij niets aan verdient. En we gaan wel met ze praten en zeggen: kijk, dat zijn de prijzen die we daarbuiten krijgen en als je ons niet helpt dan krijgen we de opdracht niet en jij dus ook niet. Dat loopt dus allemaal heel collegiaal met die leveranciers." (Rein, D)

Een ander aspect van deze verhouding is de verwachting dat als er iets bij de leverancier mis dreigt te lopen, deze zo vroeg mogelijk aan de bel trekt. Soms bestaan er standaardoplossingen die inspelen op de eigenaardigheden van het productieproces van de klant.

De zegsman van Thermo gaf een illustratief voorbeeld. Hij zei dat de leverancien van verf zo waren 'opgevoed', dat als er een probleem dreigde te ontstaan met het tijdig leveren van voldoende verf van een bepaalde kleur uit de gebruikelijke serie, dit zo snel mogelijk door de verfleverancier aan de productieafdeling van Thermo

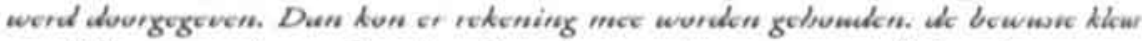
werd dan overgeslagen. Zou dat niet gebeuren, dan zou men enkele weken met een onafgewerkt product blijven zitten. "Zo zijn we eigenlijk op elkaar ingespeeld". (Thermo, D)

De klant is natuurlijk koning en daar is men zich uitdrukkelijk van bewust. ${ }^{2}$ Maar dat betekent niet dat alleen hij de eisen kan stellen. De rol van de klant bestaat waarschijnlijk vooral uit het honoreren van het coöperatieve gedrag van de leverancier met (een liefst niet aflatende stroom van) bestellingen. De zegsman van het Belgische bedrijf Kist geeft als voorbeeld dat er door de leverancier zeer snel bepaalde producten worden geleverd om testen te doen in verband met een voorstel voor een klant; of dat er in extremis nog aanpassingen nodig zijn wanneer de marketingafdeling van de klant twijfelt over een bepaalde specificatic (bijvoorbeeld de kleur) en op het laatste ogenblik van gedachte verandert, terwijl de orders voor de grondstoffen in feite de deur al uit zijn. Dergelijke flexibiliteit bij de leverancier heeft uiteraard een prijs:

"...je moet cen relatie opbouwen. Als je gaat flierefluiten en je koopt hier en daar en je geeft die mensen niets - want voor wat hoort wat - dan kun je nooit komen tot zo'n relatie flexibiliteit. Ze weten: als ik me inspan krijg ik ook een groot deel van de koek. Als de prijs juist is. Dat is de manier waarop je moet werken en de manim om je problemen opgelost te krijgen." (Kist, B)

2 Zo merkt de zegsman van Thermo over de relatie met leveranciers: "In deze relatie domineret natuurlijk onze wensen. En wanneer wij klachten hebben, dan verwachten we - omdat we de afnemer zijn - dat die behoorlijk worden behandeld." 
Het ziet eruit als een stelsel van wederzijdse beloningen dat voor zijn voortbestaan voornamelijk regelmatige bevestiging nodig heeft. ${ }^{3}$

Dit kenmerk van de relatie met leveranciers is niet alleen belangrijk wanneer het gaat om internationale chemieconcerns, maar ook bij kleinere leveranciers. Bij de firma Plaat (B) gaat het om leveranciers van kunststof dakbedekking. Daar is het opbouwen van een relatie met de leveranciers van belang voor (naast goede kwaliteit en de beste prijs) een flexibele opstelling ten aanzien van de betaling. Dat is voor het bedrijf van gewicht omdat de klanten uit de bouwsector niet vlot van betalen zijn. Als er op dat vlak moeilijkheden zijn gaat men met de leverancier praten en wordt er naar een oplossing gezocht: "In een goede relatie wordt dat panvaard en begrepen. Zo werk ik." In feite komt het er op neer dat men (tenmingte) een deel van de problemen waarvoor de klanten het bedrijf plaatsen door het pedrijf worden afgewenteld op de leverancier.

Zo ontstaan er over en weer afhankelijkheden. Het bedrijf is ten dele afhankelijk van zijn leveranciers voor het voldoen aan de wensen van de klanten. Zijnerzijds verwacht de leverancier (overigens net als het bedrijf tegenover zijn klant) op vaste klandizie van het bedrijf. ${ }^{4}$ Deze afhankelijkheid wordt ook onderstreept door Markies. Deze producent van - wat men zelf noemt - 'technische raamdecoratie' heeft te maken met pieken tijdens het zonseizoen en wil toch just-in-time beleverd worden. Dat eist zorgvuldige afstemming met de leveranciers:

"Wij noemen dat 'partners'. We kunnen niet teveel wisselen, dat is organisatorisch onmogelijk. De leveranciers moeten hun voorraden kunnen afstemmen op de opdrachten die ze van ons kunnen verwachten. Zij zijn belangrijk in het realiseren in de afspraken die wij [met klanten] maken..." (Markies)

Het beschikken over een dergelijk netwerk van partners-leveranciers blijkt ook hier een belangrijke factor voor de reductie van de kans op fricties, niet alleen met leveranciers maar blijkbaar tevens met klanten.

Men kan zich voorstellen dat een dergelijk stelsel van relaties van 'levensbelang' kan zijn als het er op aan komt. Ook daarnaast zal het voor de continuïteit

3 Er kwamen voorbeelden ter sprake van relaties die al ruim 20 jaar bestonden.

4 In ieder geval worden vaste leveranciers, ook wanneer er kritiek is, zorgvuldig behandeld. Zo gaat het in ieder geval bij Parts: $\mathrm{Er}$ is ook naar onze leveranciers de zekerheid dat we ze niet laten vallen [als de prijs iets lager is]; daar heb ik geen belangstelling voor. Wat we wel doen is, als er iemand komt met een heel goede prijs, dan checken we dat uit. Dan kijken we of die man waardig is onze kverancier te worden. Er zijn allerlei andere dingen even belangrijk als de prijs. [... Blijkt het een wardig alternatief te zijn, dan ben ik natuurlijk verplicht om met mijn leverancier te gaan praten. Dan zeg ik, sorry, ik heb dit aanbod, dat ligt voor. De relatie mankeert op een punt: de juiste prijs. En wat kunt u daaraan doen? Wat ik nooit zal doen is die leverancier zonder enige melding te laten vallen: niet voor kwaliteit, niet voor prijs, niet voor iets anders." 
en rentabiliteit van de bedrijfsvoering van gewicht zijn. Overigens blijken dezt wensen ten aanzien van de zakenrelaties niet alleen in deze branche te leven. Ze zijn bijvoorbeeld ook in de aannemerij gesignaleerd. In hoeverre men erin zal slagen de wens in werkelijkheid om te zetten, zal afhangen van de positie in de markt: niet elk bedrijf is even aantrekkelijk voor het aangaan van coöperatieve re laties. De respondenten in deze branche klinken tot dusverre alsof ze er in geslaagd zijn zich te omringen met leveranciers die grotendeels aan het gewenste profiel voldoen.

\section{C) Contracten}

Enkele Duitse respondenten stellen dat expliciete contractuele planning van transacties van belang is voor het voorkomen van problemen. Ze vinden dat vanzelfsprekend, onder verwijzing naar ISO-normen (Rein, Thermo). Schaum benadrukt sterk het belang van de documentatie rond de transactie zonder over kwaliteitsprocedures te praten:

"Wat wij doen is onze behoefte schriftelijk vastleggen, dat wij een opdrachtbevesti. ging verwachten, dat wij deugdelijke leveringspapieren krijgen en een leveringsbewijs, dat wij de goederen testen en dat wij een deugdelijke rekening krijgen. Dat betekent: wij hebben reeds binnen het bestek van de correspondentie een duidelijkt voorstelling over hetgeen we wensen te krijgen. Dat moet hij in de opdrachtbevestiging vastleggen zodat er geen verschillen in verwachtingen optreden." (Schaum, D) Contractuele planning wordt bij andere Duitse respondenten minder sterk benadrukt. Dat is bijvoorbeeld het geval bij Flasche, met name omdat er niet veel variatie in de bestellingen zit en (vooral ook) omdat er centraal wordt ingekocht. Het gaat bij hen om jaarcontracten die door het hoofdkantoor worden afgesloten (waarbij prijsafspraken worden gemaakt). De productiebedrijven kunnen vervolgens op afroep bestellen. De kwaliteit van het product is volledig gespecificeerd volgens een internationale standaard, dus daar kan weinig verschil van mening over zijn. Bij Form wordt er veelal per fax besteld (met uitdrukkelijke specificatic van het materiaal, de levertermijn, de betalingstermijn). Men krijgt daarna de opdrachtbevestiging terug en die wordt weer gecontroleerd met de bestelling. Maar soms gaat bestellen ook over de telefoon: "Maar dan weet ik dat het zin heeft, dat heeft nooit grote problemen opgeleverd."

Ook Belgische respondenten spreken over het belang van de 'stroom van juiste informatie'. Dat wil zeggen dat precies schriftelijk wordt vastgelegd wat men van de leverantie verwacht, met name op het vlak van technische specificaties. Dete documentatie is de basis waarop de verschillende onderdelen van het bedrijf ope reren. Men dient uiteraard precies te weten wat er besteld is om het gewenste product te kunnen maken. Daarnaast is die documentatie essenticel voor het geral dat men later controles wil kunnen uitvoeren en de verantwoordelijke voor gebreken wil kunnen aanwijzen (Kist). Andere vaste onderdelen zijn de prijs en de 
plaats en tijd van leveren. Over de te leveren hoeveelheden geeft men op diverse manieren indicaties af. Het gaat soms om jaarcontracten met levering op afroep zoals bij Buis. Bij Parts sluit men open contracten voor in beginsel onbeperkte hoeveelheden waarbij per order wordt aangegeven wat de te verwachte behoefte is voor de volgende drie maanden, de volgende maand en de volgende week:

"In principe gelden die afspraken voor alles behalve de prijs zolang de order duurt. Dus als ik vandaag een product begin te maken, dan heeft dat een looptijd van 4 tot 5 jaar. De kleur kan wijzigen. De grondstof blijf gewoon in gebruik. Voor alle aspecten behalve de prijs geldt die onbeperkt. En zolang ik of de tegempartij geen reden zien die raamopdracht af te breken." (Parts, B)

De bedrijfsleider van Plaat (B) hecht - overigens als enige - nadrukkelijk zo grote waarde aan wat hij noemt de 'professionaliteit' van de contracten dat hij zelf de formulering van de vaste (niet onderhandelbare) onderdelen van de contracten ter hand neemt, daarin bijgestaan door externe juridische adviseurs.

\section{D) Controles}

Een goede methode om de risico's te voorkomen die verbonden zijn aan een ondeugdelijke levering is het testen van de aangeleverde goederen. We hebben zojuist gezien dat niet iedereen dat doet (Flasche, D). Dezelfde werkwijze wordt gevolgd door Kist (B):

"Als het [de specificatie/A]] op papier staat rekenen we erop dat het zo is. We heb-

ben geen laboratorium om dat te testen. We rekenen erop dat de toeleveranciers dat hebben en quality control, dat wordt ook besproken... " (Kist)

Maar verschillende respondenten doen dat wel, hetzij in eigen laboratorium, hetzij door een externe instelling. Bij Form (D) heeft men ook geen eigen laboratorium, maar daar wordt wel een beroep gedaan op de faciliteiten van een grote klant. Een interessante methode die zij toepassen met te bestellen materiaal, is dat men een monster neemt van de leverancier; die laat men vervolgens beoordelen door de klant. Men koopt vervolgens alleen grondstoffen die de klant heeft getest en goedgekeurd. Bij Buis (B) beschikt men wel over een eigen laboratorium waar een steekproefsgewijze ingangscontrole plaatsvindt van grondstoffen op conformiteit met het productcertificaat. De hulpstukken worden visueel gecontroleerd bij aankomst en wanneer ze naar de klant gaan. Bij Parts (B) heeft men een gedifferentieerde aanpak. Het is een onderdeel van een sterk ontwikkeld kwaliteitssysteem van de grote klanten (op basis van de ISO 9001 met eigen toevoegingen), warvoor het bedrijf is gecertificeerd. De klanten verlangen ook dat de toeleveranciers van het bedrijf minstens voor ISO 9002 gecertificeerd zijn:

"Dat betekent dat $u$ een doorgedreven kwaliteitsysteem heeft met alle mogelijk controles. En wij volstaan normaal met bij elke levering een [product]certificaat te vragen. Intern, wanneer er fouten vastgesteld worden, geven we die leverancier een status. 'Groen': dat betekent alles is $O K$. Dan is er een status 'oranje' waarbij hij 
een verkeerde levering heeft gedaan. Dan versterken wij de ingangscontrole. En heeft hij een status 'rood' dan heefi hij ons ernstig in de steek gelaten en is de ing. angscontrole nog sterker. In principe proberen wij ernaar te streven onze ingang. controle te beperken tot hoeveelheidcontrole. En dat we wat betreft de kwaliteit afgaan op de certificaten." (Parts)

De overige kleinere bedrijven beperken zich tot visuele controle en tot vertrouwen in het productcertificaat.

\section{E) Kwaliteitssystemen en -procedures}

De betrekkelijke zeldzaamheid van geschillen met leveranciers kan ook mede het gevolg zijn van ISO-kwaliteitsprocedures. Een Belgische en twee Duitse respondenten wijzen hierop uitdrukkelijk. Alle overige bedrijven zijn overigens ook ISO-gecertificeerd, maar noemen de invloed van de ISO-procedures niet. Wel worden er bepaalde handelingswijzen gememoreerd die overeenstemmen met procedures voor kwaliteitsborging uit de ISO-9000 serie. Zo worden vaste leveranciers geèvalueerd, en nieuwe leveranciers worden tegen het licht gehouden. Maar het is natuurlijk niet gezegd dat dergelijke procedures alleen gehanteerd worden omdat men ISO-gecertificeerd is.

\subsubsection{Omgaan met klachten in de relatie met leveranciers}

De inspanningen om klachten te voorkomen zijn aanzienlijk en naar de respondenten aangeven succesvol. Niettemin gaat er - zoals ook bij de Nederlandse bedrijven bleek - toch nog wel eens iets fout. Problemen die in Nederland werden genoemd lagen in hoofdzaak op het vlak van: kwaliteit, kwantiteit en timing. Wat gaat er mis bij de kunststofverwerkers in Duitsland en België en hoe gaan ze met die klachten om?

Om met het laatste, ook in aansluiting op de bovengenoemde kwaliteitsprocedures, te beginnen: enkele respondenten bevestigden de feedback praktijk die ook bij enkele Nederlandse bedrijven is gesignaleerd. Eén van de gevolgen van de verspreiding van het kwaliteitsdenken is, dat in beginsel alles wat niet naar wens gaat tussen leverancier en bedrijf over en weer wordt gemeld. En al die berichten wotden ingevoerd in het systeem van klachtenregistratie, ook als het niet de bedocling is dat er aan de klacht zelf iets gedaan wordt. Op die manier heeft men een volledig beeld van wat er mis gaat en kunnen de oorzaken worden onderzocht en mogelijk worden weggenomen, geheel overeenkomstig de adagia van het moderne kwaliteitsmanagement. Zo zegt de zegsman van Parts (B) dat gebrekkige produc ten voor een bepaalde tijd voor de leverancier beschikbaar blijven zodat hij ze kan ophalen voor nader onderzoek naar de mogelijke bron van de gebreken:

-...in ieder geval gaat er elke maand een fax buiten waarop staat: mijnheer, dast maand waren er 6 of 8 slechte van de 10.000 stuk. Ze worden bij ons bewaard en 1 
heeft een bepaalde tijd om ze bij ons op te halen. Wat zie je meestal: wanneer die fout begint te stijgen dan is er van ons ook een actie naar hem: let op, want dit is gaande. Wanneer het beneden de 50 of $100 \mathrm{ppm}$ [parts per million/A]] blijf dan reageert hij daar niet op. Binnen de marge? Gooi ze weg en trek ze af lvan de rekeningl."

Ook biedt de klachtenregistratie een basis voor een evaluatie. Verschillende bedrijven maken melding van de (minder vrijblijvend ogende) praktijk om jaarlijks de plus- en de (gedocumenteerde) minpunten van de relatie op een rij te zetten.

"Wat ik nooit zal doen is de leverancier zonder enige melding te laten vallen: niet voor kwaliteit, niet voor prijs, niet voor iets anders. Gelijk mijn klanten met mij doen. In onze wereld gaat het niet op dat je met de grote middelen werkt, dat je kapt. Je zet elkaar om de tafel, je gaat praten: de goeie dingen zijn dit en dit, de onaangename kantjes zijn dat en dat. Wat kunnen we doen om de relatie op die punten waarover ik niet zo tevreden ben aan te passen? Omgekeerd hebben zij ook het recht om naar mij toe te stappen en te zeggen: we hebben last van wat jij doet, met afroepen of zo. Hoe maken we het beter?" (Parts, B)

"Dat hebben we nu ingevoerd. Wij registreren de fouten die er geweest zijn in een jaar. En op het einde van het jaar gaan we praten naar de toekomst toe, over projecten, en dan komt het boek van Sinterklaas te voorschijn. Kijk eens, daar en daar hadden we toch wel problemen. En naar de toekomst toe...Dat willen we vergelijken, of daar een evolutie in is. " (Kist, B)

De zegsman van Kist geeft aan dat er desnoods vergaande consequenties aan zo'n foutenregistratie verbonden kunnen worden:

"Ik weet, sommige bedrijven werken met codering. Je bent een A-leverancier of een B. Als je cen X-aantal fouten hebt dan lig je eruit. Dus daar zijn we nu mee bezig om dat in te voeren. Maar het begint met een registratie. Je kunt niet zomaar in de lucht gaan praten. Maar als je dat gefundeerd kunt doen..."

Binnen een dergelijk regime moet ook een vaste leverancier blijven opletten. Wanneer men binnen een bepaalde foutenmarge blijft zal dat (mits de fouten in overleg hersteld worden) weinig consequenties hebben voor de relatie. Maar wie de marges overschrijdt zonder daarin verbetering te brengen kan verwachten stapsgewijs op weg te zijn naar de uitgang.

Resten nu nog de aard van de meest voorkomende klachten.

\section{A) Kwaliteitsgebreken}

Met name op het vlak van de kwaliteit worden wel problemen gemeld, zij het van beperkte omvang. Verschillende respondenten schatten het in de orde van grootte van twee procent van het totaal. Er wordt dan ook wel gepoogd mogelijke kwaliteitsgebreken zo snel mogelijk te signaleren via de gememoreerde controles. Als het gebrek vroegtijdig wordt vastgesteld dan gaat de zending terug en krijgt een 
Iwaar worden opgevangen en uit de weg geruimd. Mocht het er dan toch nog naar uitzien dat er tekorten ontstaan dan wordt bij een ander besteld en wordt de oorspronkelijke leverancier aangesproken voor de schade. Het gaat daarbij met name om het prijsverschil want doorgaans geldt de regel: wie geen vaste klant is en haast heeft, betaalt een hogere prijs.

Soms wordt bij dit type problemen door de leverancier met succes een appèl gedaan op 'flexibiliteit' van de klant. Thermo (D) zegt dat er soms wel vertragingen in leveringen optreden (ongeveer 1 maal per maand), bijvoorbeeld als gevolg van een defecte weefstoel. De leverancier meldt het defect [direct] en er worden dan nieuwe termijnen afgesproken. Misschien moeten ze dan in het weekend doorwerken om het te halen. Maar er zijn op dit gebied weinig moeilijkheden. Ook enkele Belgische bedrijven geven aan ook gevoelig te zijn voor het relaas van de leverancier:

"Ik heb een leverancier in Duitsland, die levert ons verticalen, een zeer goed levenancier. Die heeft stoffen die nu al 7 of 8 weken over tijd zijn. Omdat ze niet afgewerkt kunnen worden. Problemen. Klanten die misteureden zijn. Dan doet die man zijn verhaal en dan zeg je: ja, het is een samenloop, de spinnerij maakt fouten, dan dat, dan dat... Dat zijn zaken die gebeuren en daar heb je dan begrip voor. Het moet je maar gebeuren, dat die dingen samenkomen bij zo'n stof. En je gelooft het verhaal van die mensen. Dit is niet normaal." (Markies, B).

"Te laat komen van leveringen... dan gaan er rekeningen. Dat staat in het contract. Maar als ik een serieuze nitleg krijg en ik kan me daarbij neerleggen, dan geef ik dezelfde uitleg aan mijn klant. Als het een serieuze klant is, is het ook aanvaardbaar. We proberen het op een serieus-menselijke manier op te lossen. "(Plaat, B) Maar doorgaans wordt, als er te laat geleverd wordt, de eventuele schade die daar het gevolg van is in rekening gebracht.

De vraag of de feitelijk geleverde hoeveelheid overeenstemt met wat de papieren vermelden is slechts zelden een grote zorg. De tankwagens van chemieconcerns zijn geijkt en de lading wordt volgens protocol gewogen:

"Als ik 5 ton bestel en er komt 4,8 ton, is dat eigenlijk geen probleem. Als er cen tankwagen komt wordt er in kilo's gerekend en dat wordt betaald. Bedrijf $Y$ heeft een weegprotocol voor de tank. Die [wagen] wordt bij ons leeggemaakt en verder kunnen wij dat niet nacontroleren. [We krijgen ook wel goederen in vaten] In vaten zit altijd 220 kilo. Het aantal vaten kan men controleren en dat doen we ook. Niet of er een kilo meer of minder in zit." (Form, D)

Er zijn dus enkele standaardoplossingen voor klachten ten aanzien van de leveranties. Welke gekozen wordt is afhankelijk van de aard en de omvang van de klacht en eventueel de verzachtende omstandigheden die leverancier weet aan te voeren. Confrontaties met leveranciers doen zich over deze kwesties zelden voor. 


\subsection{Klanten}

De relatie met de klanten is in deze branche min of meer een spiegelbeeld van die met de leveranciers. In deze relaties doet zich eveneens, door vergelijkbare inspanningen van de Duitse en Belgische kunststofverwerkers om klachten te voorkomen, betrekkelijk weinig conflictstof voor. We zullen de belangrijkste elementen in de klachtenpreventie langslopen en daarna de klachtenbehandeling nader bezien.

\subsubsection{Klachtenpreventie in de relatie met klanten}

\section{A) Selectie: 'assemblers' en duurzame relaties}

De geïnterviewde Belgische (Parts, Kist en gedeeltelijk Buis en Plaat) en Duitse (Flasche, Thermo, Schaum, en gedeeltelijk Rein) productiebedrijven verkeren wat de relaties met de klanten betreft in een grotendeels vergelijkbare positie. Deze bedrijven onderhouden relaties met een beperkt aantal min of meer permanente opdrachtgevers waaraan grote porties van de productie wordt verkocht. Het prototype van dergelijke klanten zijn 'assemblers', dat wil zeggen bedrijven die aan de top van een productienetwerk staan en die het eindproduct uit onderdelen samenstellen en distribueren. Dit zijn veelal internationaal opererende megaconcerns die wat betreft de toelevering trachten zo min mogelijk aan het toeval over te laten. De relaties met de toeleveranciers (onze productiebedrijven dus) zijn vaak complex en er worden hoge eisen gesteld.

Er worden onder druk van de opdrachtgevers hoge kwaliteitsmaatstaven gehanteerd. Het bedrijf moet in staat zijn producten te leveren die aan zeer nauwkeurig omschreven technische specificaties voldoen. Daarnaast dient het productieproces in alle onderdelen op de wensen van de klant georiënteerd te zijn. Fouten moeten niet alleen opgespoord en afgehandeld worden, maar ook geregistreerd, op hun oorzaak onderzocht en in het vervolg voorkomen worden. De aanwezigheid van een kwaliteitssysteem is een indicatie dat daarvoor procedures zijn ingevoerd. In bepaalde sectoren houdt de opdrachtgever er een eigen kwaliteitssysteem op na. Vaak ook wordt het product in samenwerking tussen experts van het bedrijf en de opdrachtgever (en soms ook de leverancier van het bedrijf) ontwikkeld.

Als de situatie aan de leverancierskant dezelfde trekken vertoont zijn de omstandigheden optimaal voor het tot stand komen van een goed geoliede productic machine waarin klachten en conflicten tot een minimum worden gereduceerd. Ter illustratie van deze wat abstracte schets twee voorbeelden.

Flasche (D) is een bedrijf dat sterk verknocht is aan een aantal grote, vaak globsle klanten. Het zijn grotendeels transnationale concerns die wereldwijd voedings: middelen (olie, ketchup, water etc.) en andere huishoudelijke consumptiegoederen 
(wasmiddelen, shampoo, reinigingsmiddelen etc.) fabriceren. Daarnaast bedient Flasche een groep bedrijven die handelen in 'witte' producten uit dezelfde sector. Met deze bedrijven wordt een hechte relatie opgebouwd. Daarbij speelt enerzijds het product een rol: samen ontwikkelen Flasche en de opdrachtgever een container overeenkomstig de wensen van laatstgenoemde, waarvoor vervolgens een productie-installatie wordt ingericht die alleen voor deze opdrachtgever gebruikt kan worden. De klant moet deze kosten via de afname van containers opbrengen, anders draait hij op voor de gemaakte kosten. De containers kunnen immers niet an andere klanten worden geleverd omdat het model het eigendom van de oorspronkelijke klant is en blijft. Men zit dus voor een bepaalde duur aan elkaar vast, anders komt de klant niet uit de kosten. Flasche gaat er bij de vestigingsstrategie min of meer van uit dat de klant niet al te wispelturig zal zijn. Wanneer een kandidaat-afnemer een bepaald volume (het gaat om tientallen miljoenen stuks) wil afnemen is een nieuwe vestiging verantwoord. De productiefaciliteit van Flasche wordt dan in, naast of vlakbij de fabriek van de klant opgetrokken. Soms gaan de geproduceerde containers direct de fabriek van de klant in. Eenmaal gevestigd heeft Flasche nog de mogelijkheid naar nieuwe klanten in die omgeving (in verband met de vervoerskosten binnen een bepaalde actieradius) uit te zien. Het gaat dus om een vrij sterke mate van symbiose. Die wordt natuurlijk wel vergemakkelijkt door het feit dat het vaak dezelfde klanten zijn die meer van hetzelfde willen.

Parts (B) vertoont een sterke gelijkenis met bedrijven als Flasche (D) en Rubber (NL). Met vrijwel alle klanten van Parts bestaan al relaties zolang het bedrijf bestaat. De kunststof auto-onderdelen die Parts fabriceert worden in nauw overleg met en vaak ook in samenwerking met de klanten ontwikkeld. Daarbij heeft de klant ook een belangrijke stem in het bepalen van de specificaties van de grondstoffen en soms ook van de keuze van de grondstofleverancier. Op grond van die ervaring zijn de bedrijven op elkaar ingespeeld wat betreft elkaars mogelijkheden en wensen. In het netwerk rond Parts wordt een dominante rol gespeeld door enkele internationale autofabrikanten waarvoor wordt gewerkt. Grote porties van de productie worden verkocht aan dit zeer selecte gezelschap. Deze fabrieken hanteren een eigen kwaliteitsregime dat zij ook aan hun directe ('first tier') tocleveranciers opleggen. Er wordt veel aan gedaan om de kans op productiefouten zo klein mogelijk te maken. Al in de fase van de ontwikkeling is men daar al mee bezig:

6 Zo was er sprake van, dat cen grote klant van plan was cen grote fabrick in Azië op te zetten. Het moederbedrijf van Flasche werd uitgenodigd mee te gaan voor de productie van de benodigde miljoenen containers. 
"Als wij beginnen met het ontwikkelen van het product is het eerste wat wij doen: een foutenanalyse schrijuen die eruit bestaat een aantal mensen rond de tafel te brengen [o.a. zijdens de klant/AJ], een aantal technici en die zeggen: als wij dit product maken, wat kan er dan fout gaan? Wat weten wij uit ervaring en hoe kun. nen we al bij de ontwikkeling van het product vermijden dat het fout gaat; dw dingen doen die later tot effect hebben dat het niet meer fout gaat. Dat doe je enerzijds voor de ontwikkeling en dat doe je anderzijds ook wanneer je het productiproces en het product gaat analyseren. Bij die foutenanalyses zijn altijd een aantal elementen die te maken hebben met de leverancier. "(Parts, B)

Een dergelijke werkwijze is ongetwijfeld gerelateerd aan de foutenmarges die de autofabrikanten hun directe toeleveranciers toestaan:

"In onze wereld maken wij elke maand een analyse van de onderdelen die wij aan de klant fout leveren. Wat je fout mag leveren is (afhankelijk van het product) tus. sen de 50 en 500 ppm (parts pro million). Maar wij streven naar zero. En er zijn ook maanden dat wij dat halen. En idem dito naar onze leveranciers want die keten moet shiten." (Parts, B)

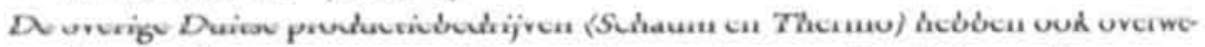
gend grote klanten waarmee al jaren zaken gedaan worden. Schaum levert voor $80 \%$ aan vaste klanten uit de groothandel in hoofdzakelijk Europa. Thermo verkoopt het grootste deel van de omzet aan de verkoopmaatschappijen van de eigen moeder (die ook producten van anderen verkopen). Een klein gedeelte van de omzet wordt verkocht aan...concurrenten. Daarover zo dadelijk meer.

De duurzaamheid van de relaties met klanten wordt - evenals bij de leveranciers - door de bedrijven gezocht op grond van vergelijkbare redenen. Het geeft de afzet het perspectief van continuïteit:

"In de eerste plaats de contimuïteit. Waar overigens ook onze klanten waarde aan hechten. Door de jarenlange samenwerking kent men elkaar wederzijds, wordt daar een vertrouwensrelatie opgebouwd. Wat de prijs betreft moet je zakelijk zijn. Dat spreekt vanzelf. Maar als ik een billijke prijs kan bieden krijg ik steeds de opdracht tegenover een nieuwe concurrent." (Flasche)

In ruil daarvoor wordt de 'goede' klant uitdrukkelijk als koning behandeld (en dat verwacht hij waarschijnlijk ook). ${ }^{7}$ De klant moet men koesteren, aldus de zegsman van Schaum (D). Men is er dus op uit de klant zo min mogelijk aanleiding

7 Ook hier hebben we te maken met een stelsel van wederzijdse beloning, met een voornamelip zakelijk karakter. Zo moet de prijs niet teveel met die van de markt uit de pas lopen, anders is het gedaan met de duurzame relatic. Een enkele maal (bij Rein) wordt er gesproken vat kameraadschappelijke relaties "die zijn opgebouwd doordat men ook private contacten onderhoude. Samen uit eten, soms ook samen op vakantic." Bij dit bedrijf doet men tevens aan "klantenzorg' on 'klantenadvies'. 
tot klagen te geven, niet alleen omdat het ISO-kwaliteitssysteem dat voorschrijft, maar vooral om de goede klant te behouden. Binnen het bestek van dergelijke duurzame relaties zal de kans op het ontstaan van klachten tevens worden gereduceerd, doordat men op elkaar ingespeeld geraakt is en ook doordat producten samen met de opdrachtgever worden ontwikkeld.

\section{B) Projecten en toch vaste klanten}

Twee Duitse bedrijven (Rein en Form) zijn gedeeltelijk productiebedrijven, maar houden zich daarnaast ook bezig met projecten. Ook het Belgische Kist is een projectbedrijf. Deze projectmatige werkwijze is een interessant punt want dit zou - indachtig hetgeen bij de Nederlandse bouwbedrijven gesignaleerd is tengevolge van eenmalige projecten voor telkens wisselende klanten - kunnen betekenen dat er bij dit segment vaak problemen zijn. Dat wordt evenwel door de Duitse respondenten niet zonder meer bevestigd. Voor een deel is de verklaring voor dit gegeven waarschijnlijk dat de klanten in dit segment voortdurend een beroep op deze bedrijven doen voor telkens nieuwe projecten. Dat heeft wel de beperking van het eenmalige product, maar ook het voordeel van de permanente samenwerking. Bovendien wordt dit aspect van de verhouding versterkt door het feit dat beide bedrijven het product samen met hun opdrachtgever ontwikkelen. Bij Rein zegt men dat deze klanten - grote firma's die in verschillende delen van de wereld energie-installaties bouwen - vrijwel geen problemen opleveren. De meeste problemen (overwegend betalingsproblemen) ontstaan met de m.k.b.-klanten die Rein in serie gemaakte onderdelen van airconditioningmachines levert. Form (D) heeft echter ook klachten over zijn grote projectmatig werkende opdrachtgevers. Mogelijk speelt hierbij een rol dat Form een zeer kleine speler is in deze wereld die men als grote opdrachtgever ongestraft wat achteloos kan behandelen. Rein is een onderdeel van een veel groter concern en een dergelijke handelwijze zou in dat geval mogelijk ongewenste repercussies kunnen hebben.

Ook het Belgische bedrijf Kist is een projectmatig werkend bedrijf. De klanten van Kist willen niet alleen mooie en sterke kratten, ze willen ze soms ook zeer snel aangeleverd krijgen. Want als zonnig weer de consumenten extra dorstig makt willen zij hun frisdranken en bieren snel in de winkel en op het terras beschikbaar maken. En daarvoor zijn de kratten onontbeerlijk. Dit betekent dat het bedrijf de flexibiliteit moet hebben om vraagpieken op te kunnen vangen teneinde de klanten tevreden te kunnen stellen (en te kunnen behouden). Die flexibiliteit is bij Kist toch al onmisbaar omdat de productiecontinuïteit niet zo berekenbaar is als bijvoorbeeld bij Parts. De kratten worden niet permanent geproduceerd, maar het gaat om een opeenvolging van kortere productieprojecten voor verschillende kratten. De kratten hebben in beginsel een vrij lange levensduur en de klant heeft er maar een bepaald aantal van nodig om zijn productie naar zijn afnemers te kunnen brengen. De kratten komen daarna weer terug en 
kunnen zo jarenlang dienst doen. De aanmaak van kunststof kratten gebeurt derhalve in een 'run' van enkele maanden waarin de hele gevraagde hoeveelheid wordt geproduceerd. Daarna worden er weer andere kratten geproduceerd voor andere opdrachtgevers of voor dezelfde, maar dan voor andere producten. Als het goed gaat ontstaat er een successie van projecten voor een groep duurzame en grotere klanten, waardoor er toch weer continuïteit in de productie ontstaat. Maar de planning is duidelijk kwetsbaar, wat nog versterkt wordt door de seizoensinvloeden op de vraag. Dat vraagt de nodige flexibiliteit van het machinepark ("als jeer voor de piekmomenten 9 [spuitgietmachines/AJ] nodig hebt, dan moet je er 9 hebben") en van het personeel (ploegendienst, vakantie als het slecht weer is, flexwerk). Dit zijn de elementen die van wezenlijk belang worden geacht voor het voldoen aan de wensen van de klant op het gebied van de leveringstermijn, en derhalve ook voor het voorkomen van klachten van de klant over het overschrijden van de leveringstermijn.

\section{C) Schriftelijke contracten}

Voor het voorkomen van problemen wordt wederom goede documentatic als een belangrijk middel genoemd:

"Er is een opdracht waar alles in komt te staan. Men maakt een offerte met veel in. formatie zodat de klant weet wat hij onder die voorwaarden bestelt: [specificaties van] het onderdeel, het materiaal, levering en de betaling. Hij bestelt dan op grond van die informatie. En dan krijgt hij weer een opdrachtbevestiging terug. Dan moet alles duidelijk zijn, zowel wat hij moet betalen als wat wij moeten leveren." (Form, D)

Het belang van de productspecificaties wordt ook sterk benadrukt door de zegsman van Kist (B). Naar zijn zeggen hebben verkopers teveel de neiging zelf teveel te praten in plaats van goed te luisteren naar wat de klant wil. Het gevaar bestaat dat er dan misverstanden ontstaan. Het is zaak goed te luisteren naar wat de klant wil en op basis daarvan met de ontwikkelingsafdeling een product te ontwerpen. Daarna wordt het weer aan de klant voorgelegd om te horen of dit het product is dat hij voor ogen had. Zo komt men tot een product waar beide partijen gelukkig mee zijn. Deze specificaties worden uitvoerig gedocumenteerd, niet alleen voot de klant, maar ook voor de ontwikkelingsafdeling:

"Die mensen die ontwikkelen kunnen dan nooit zeggen: "dat heeft u nooit verteld". Dat staat mooi op papier. En dat is een formulier dat [door de verkoopleider] wordt afgetekend: ze hebben begrepen wat hier ingevuld is. "(Kist, B)

Maar de positie van de opdrachtgever is sterk en als het zo uitkomt, houdt hii blijkbaar soms ook zijn opties open:

"In principe krijgen wij een contract voor de levensduur van een product. $U$ mods dat ook zo zien: zijn dat vaste geschreven contracten? Ja en nee. Er staat nergens dat het voor de levensduur van het product is. Er wordt dus wel een prijs bepaald en ent 
technische specificatie. Wij maken meestal de matrijzen. Die zijn meestal het eigendom van de klant. Dat betekent dat hij in principe de productie weg zou kunnen nemen. Maar daar zit zo'n ontwikkelings-know-how achter, daar zit een geschiedenis achter, dat het al heel erg moet zijn wil er geresourced worden. Ik zeg niet dat het nooit gebeurt. Met ons is het nooit gebeurd maar we hebben in onze groep wel eens cen product overgenomen dat van ergens anders kwam. Maar dan moet de relatie al heel erg verziekt zijn. "(Parts, B)

\section{D) Kwaliteitssystemen en -procedures}

$\mathrm{Na}$ alles wat reeds over de kwaliteitsprocedures in het voorgaande is gezegd kunnen we hier kort zijn. Het merendeel van de bedrijven in deze sector bleek ISO-gecertificeerd. Bovendien worden in sommige sectoren (zoals de automobielindustrie) bedrijven onderworpen aan een regelmatige kwaliteitstest van hun grote internationale opdrachtgevers. Maar ook minder internationale opdrachtgevers kunnen veeleisend zijn.

Bij het Belgische productiebedrijf Buis vertoont met name de afzet aan grote klanten (zoals water- en gasmaatschappijen) sterke gelijkenis met de klantenverhouding van de zojuist genoemde bedrijven: het zijn duurzame en grotere afnemers die over het algemeen braaf hun rekeningen betalen, maar voor het overige wel veel noten op hun zang hebben. Bij Buis betreft dat vooral de kwaliteit van het product. Om die zoveel mogelijk te garanderen gaat men niet over een nacht ijs. 'Men', dat wil zeggen: niet alleen het bedrijf maar ook de water- en gasmaatschappijen zelf. Deze klanten mengen zich niet (anders dan via specificaties) in de aankoop van grondstoffen. Maar de bemoeienis met het voldoen van het product aan de gestelde specificaties is ingrijpend. De machines waarmee de kunststof buizen worden gefabriceerd worden door een onafhankelijke instantie getest op hun vermogen bepaalde specificaties (overeenkomstig NBN-normen) te produceren. Dan pas is de opdrachtgever akkoord met het produceren van een bepaald buistype op een bepaalde machine. Wanneer de buizen geproduceerd zijn, controleert men in het eigen laboratorium de kwaliteit. Maar de grote klanten doen daar nog een schepje bovenop. De watermaatschappijen laten elke week een volledige visuele en administratieve controle doen en laten de buizen voorzien van een kwaliteitszegel. Alleen deze buizen mogen door (de erkende) annemers worden gebruikt. De gasmaatschappijen laten de buizen steekproefsgewijs onder supervisie in het laboratorium van de firma zelf testen. In dit afzetsegment doen zich van de kant van de klant weinig klachten voor. Bovendien zijn er weinig klachten over de betalingsbetrouwbaarheid van deze categorie klanten. 


\subsubsection{Omgaan met klachten in de relatie met klanten}

Al deze factoren samen reduceren het aantal klachten van de kant van de opdrachtgevers tot een hanteerbare omvang. En de meeste geselecteerde bedrijven zijn dermate solide dat betalingsproblemen zeldzaam zijn. Maar toch zijn er soms problemen. Hoe gaat men met deze klachten om?

\section{A) Betalingsproblemen.}

Voor het merendeel zijn de grote vaste klanten van deze kunststofverwerkers betrouwbare betalers. Problemen doen zich op dat vlak zelden voor. Maar dergelijke problemen zijn niet met alle klanten uit te sluiten. Voor nieuwe (onbekende) klanten tracht men dergelijke risico's af te dekken met het inwinnen van informatic. Voor buitenlandse (exotische) relaties wordt het risico gedekt door een kredietverzekering. Dat is in deze branche een veel gebruikt instrument. En als men een slechte ervaring heeft gehad of het risico te groot vindt, dan levert men alleen tegen vooruitbetaling.

Als er onverhoopt toch betalingsproblemen ontstaan dan zijn er de vaste routines van aanmaning, persoonlijk contact, inschakelen van de advocaat. Overigens wordt er wel een onderscheid gemaakt: als het een erg goede klant is probeert men die te helpen met de financiering:

"We stellen voor dat hij ons een wissel geeft die 90 dagen looptijd heefi, dan heeft

hij weer even lucht. Dat kost hem niets. Of we verlenen hem een bijzonder krediet.

Dat gebeurt wel eens." (Rein)

Interessant is dat sommigen erop wijzen dat de betalingsmoraal niet overal hetzelfde is:

"Ja, waar beginnen de betalingsproblemen? Er zijn nu cenmaal klanten dic je moet aanmanen, als de betalingstermijn verstreken is...en dat is verschillend tussen klanten (afspraken) en ook in verschillende landen. Frankrijk en België hebben lange termijnen tot 90 of 120 dagen; daar beeft men een bepaalde zekerheid nodig. Want in drie maanden kan ik een half miljoen flessen bebben geleverd en ik beb geen geld. [...] Duitsland is relatief goed in betalingsmoraal. Daar zijn veel mensen die met korting betalen: als ze binnen 10 dagen betalen krijgen ze 2 of $3 \%$ korting En anders is 30 dagen gebruikelijk." (Flasche)

Blijkbaar zijn er dan ook verschillen in opvatting over wanneer er een probleem is. Bovendien neemt men die zaken niet overal even zwaar op. Volgens de zegsman van Thermo beschouwen ook grote bedrijven in Italië het te laat betalen als een soort sport. Hij pareerde die tactiek door de levering stop te zetten. En tot zijn verbazing had hij gemerkt dat zo'n firma na verloop van tijd weer met een bestelling kwam alsof er niets gebeurd was.

Over het algemeen probeert men dus juridische stappen te vermijden en ook als men geen andere weg ziet dan verwacht men er weinig heil van. Soms wordt 
ervoor gekozen het verlies maar te nemen. Niettemin worden er met dergelijke klanten na verloop van tijd (onder bepaalde condities) toch wel weer zaken gedaan.

\section{B) Overige klachten}

Wat betreft de overige standaardproblemen (kwaliteit, kwantiteit en timing): men is erop uit die zo snel mogelijk en in der minne uit de wereld te helpen. Als de klant zegt dat er een probleem is dan is er een probleem:

"De firma $Z$ (grote multinational) meet alles na en als er iets niet klopt dan is er een probleem. Dat komt wel eens voor. En bij zo'n klant moet je niet de flinke vent gaan uithangen. Die moet terugkomen." (Form, D)

Voor het oplossen van dergelijke klachten bestaan routines die erg gelijken op de routines die we ook in Nederland zijn tegengekomen. Kwaliteitsproblemen poogt men te herstellen. Afhankelijk van de omvang van het probleem worden leveringen teruggenomen of worden de defecte producten op kosten van het bedrijf uit de levering geselecteerd en gefactureerd.

Voorts zijn er soms aansprakelijkheidskwesties die met enige regelmaat terugkeren. Dat is het geval bij Buis (B). Het gaat daarbij vooral om de afzet van hulpstukken voor waterleidingen. Er treden regelmatig moeilijkheden op met hulpstukken. Die moeilijkheden nemen meestal de vorm aan van schadegevallen door defecten die na plaatsing aan het licht komen. Er gaat dan iemand van de kwaliteitsafdeling van het bedrijf ter plekke op inspectie om vast te stellen waar het defect door veroorzaakt is. Het kan ontstaan door een foute installatie door de aannemer, maar ook door een gebrek in het hulpstuk. In sommige gevallen kan men er samen met de aannemer uitkomen, in andere gevallen loopt de afwikkeling via de verzekeringsmaatschappij. Er worden pogingen gedaan te leren naar aanleiding van dergelijke klachten:

"Vorig jaar hebben we problemen gehad met enkele bochten. Daar hebben we verschillende schadegevallen mee gehad. Toen hebben we door de leverancier testen laten doen hoe dat kwam en hebben we een oplossing gezocht. We hebben gezorgd dat de producten nu in ander materiaal gespoten zullen worden en sterker zijn ook. Maar dat is inderdaad een langdurig proces want ik weet dat we er twee jaar geleden mee begonnen zijn om al die klachten te sorteren. En er moet veel schade zijn eer dat de leverancier wil kijken of het zijn fout is. Voordien wordt er heel wat heen en weer geschreven." (Buis, B)

\subsection{Concurrenten}

Door alle Duitse bedrijven wordt de concurrentie gekenschetst als hard, vooral op het vlak van de prijzen. Maar er wordt niet veel geklaagd over dingen die niet door de beugel kunnen. Ook niet over het schenden van patenten. Bij Flasche is dat 
vooral een kwestie van de klant: die is de eigenaar van het model. Bij Thermo zouden patenten niet meer zo van belang zijn (maar men heeft wel video rond de productie geplaatst toen er 'vreemde dingen' gebeurden). Dat is wel het geval in de sector waarin Schaum opereert. Volgens de zegsman van Schaum houden de concurrenten elkaar scherp in het oog: het gaat echter meer om 'kapieren' dan om 'kopieren'. Door Schaum wordt het enige conflict met concurrenten (i.c. over een patent) gemeld waarin ook met gerechtelijke stappen is gedreigd. Het ging om een patentclaim waarvan Schaum vond dat het eigenlijk ging om een onderdeel van de 'huidige stand der techniek'. Met het dreigement de kwestie juridisch te willen laten beslechten, lukte het om de andere partij rond de tafel te krijgen en tot een compromis te bewegen. Rein zegt veel patenten (enkele honderden) te hebben waarvan de bewaking in handen is gegeven aan een wereldwijd netwerk van patentadvocaten:

"Het komt voor, maar de concurrentie is niet sterk. Het zijn er geen honderdtallen, maar 5 tot 8. En die zullen zich er wel voor hoeden zoiets regelmatig te doen. Ze weten dat wij dat ook niet doen."

Form overziet het concurrentieveld niet zo goed omdat het bedrijf zoveel verschillende producten maakt. Overigens heeft men bij Form geen klachten over de concurrentic.

Er blijkt nogal eens met de collega's te worden samengewerkt. Schaum en Thermo produceren voor hun concurrenten en omgekeerd. Er zijn verschillende redenen om daartoe over te gaan. Soms levert het bedrijf een kwaliteit die de concurrent niet kan fabriceren; zo kan Thermo breder doek leveren dan de concurrent. Soms is de prijs (door productiemethode) aantrekkelijker. En soms geeft het gemak van de plaatselijke connecties de doorslag (Schaum). Flasche is soms door de klant gedwongen samen te werken met een concurrent, als die bijvoorbeeld door twee bedrijven beleverd wil worden. Maar men streeft ernaar (met sterke argumenten ten aanzien van prijs, zekerheid en kwaliteit) dit waar mogelijk te vermijden. Rein meldt nog een regelmatig contact over prijzen met de concurrenten waarmee men op goede voet staat: "we moeten uitkijken niet de indruk te wekken een kartel te zijn."

Bij de Belgische bedrijven wordt weinig geklaagd over oneerlijke praktijken van concurrenten. Alleen de zegsman van Plaat zegt dat hij de indruk heeft uit beroepsorganisaties te worden geweerd sinds zijn bedrijf deel uitmaakt van een Frans concern. Hij wijt deze chauvinistische houding aan overcapaciteit in deze productiesector. Samenwerking met collega's wordt gemeld door de zegslieden van Buis en Kist. Bij Buis sprong men bij toen een nabijgelegen fabriek van een collega afbrandde. Door Kist wordt regelmatig samengewerkt in grote projecten. De samenwerking betreft dan vooral de ontwikkeling van het product: dat moet dezelfde specificaties hebben. Op het vlak van de prijs gaat ieder zijn weg. 
In de gesprekken hebben enkele respondenten gewezen op spanningen met name in de relatie met klanten die een nadere beschouwing waard zijn. Het gaat met name om de effecten van de verscherping van concurrentie op het alliantienetwerk dat de bedrijven trachten in tact te houden. De zegsman van Kist wees op het verschijnsel dat enkele grote klanten de flexibiliteit van het bedrijf op het vlak van productiesnelheid op de proef stelden door steeds kortere levertermijnen te bedingen:

"Er zijn zeer grote bedrijven, wat inherent is aan grote bedrijven, die zeggen "ik ben de grootste, dus jullie moeten wel volgen wil je blijven leveren bij ons". En als dan een of andere grote Piet zegt "zo is het" en die neemt zijn wens voor werkelijkheid aan en alle mensen die er onder zitten brengen de boodschap door, wetende dat de toeleverancier het niet kan, maar toch zegt "men heefi gezegd dat het moet", dan heb je een probleem. Soms zeg je dan wel eens ja, je kleedt het nog in, het gaat niet. Maar je kunt niet zeggen dat het niet gaat. [...] je gaat uit elkaar zonder een akkoord te hebben. De één blijf op zijn standpunt staan, de ander ook. [...]

Als dat de markt is, daar zijn we naar gegroeid, dan kun je daar wel over zeuren ("dat is toch niet normaal dat ze dat vragen?"). Degene die dan op winst speelt van collega-bedrijven, die is de man, die kan het wel. Die gaat proberen je iets voor te zijn. De grenzen worden steeds verlegd. " (Kist)

Dergelijke ontwikkelingen kunnen leiden tot klachten en conflicten als het bedrijf er niet in slaagt aan de (op dat moment niet realistische) eisen van de klant te voldoen. De duurzame oplossing van een dergelijk probleem is niet zo evident. Het is onzeker of dergelijke klanten de extra kosten die verbonden zijn aan het voorzien in de noodzakelijke voorwaarden voor snellere productie (machines, personeel) zullen willen betalen. Ook wat de prijs betreft zullen er kapers op de kust zijn.

Voorts is in dit verband een opmerking van de zegsman van Plaat vermeldenswaard die eveneens te maken heeft met de effecten van toegenomen concurrentie, met name wat betreft de frequentie van klachten en de kans op duurzame relaties. Naar zijn zeggen staan in Europa door toegenomen concurrentie de prijzen in de bouwsector, waaraan hij hoofdzakelijk levert, onder druk. Daardoor gaat iedereen economiseren en ook de leverancier is gedwongen in zijn eigen keuken te gaan kijken. Die gaan te rade bij hun technische mensen en dan wordt er aan de kwaliteit gesleuteld:

"Dan komt het product aan. Wijzien het niet onmiddellijk. En men merkt het pas als het wordt verwerkt. En dan zijn het de klanten die reclameren. En dan gaan natuurlijk de poppetjes dansen. Het is niet zo moeilijk om een stuk te nemen. Ik vlieg naar het labo en laat het testen. Dan zie je toch wel dat hier en daar de resultaten ietsje minder zijn. Maar net zoveel - die leveranciers zijn zo slim-dat ze nèt boven de grens van de fourchette [kwaliteitsmargelAJ] werken." (Plaat) 
Eventuele klachten van de klanten tracht men overigens vooral 'commercieel' op te lossen. Dat houdt in dat er een technisch geschoolde verkoper aan de klant uit komt leggen hoe de vork in de steel zit: "En dat wordt nogal eens aanvaard." Als de kwaliteit onder de tolerantie komt wordt het product teruggenomen. Maar meestal ("die leveranciers zijn zo slim") zit men net binnen de tolerantie.

Maar de klanten weten wat er gaande is en het kan een reden voor ze zijn om naar een concurrent-leverancier over te stappen. De verkooprelaties zijn door de slinkende marges 'fragiel' geworden. Als er maar iets fout gaat of er is elders een aantrekkelijker prijs dan haakt men af: "...tegenwoordig kan elk punt vanaf de inkoop tot aan de betalingstermijn een reden zijn naar een ander te gaan." De scherpere concurrentie kan op die manier de kans op klachten vergroten en de kans op duurzame relaties met klanten verkleinen. Wat dit laatste betreft zegt de zegsman van Plaat: "Dus ik beweer: een klant? Je hebt geen klant in de oude zin van het woord."

\subsection{Geschillen en juridische stappen}

Er is duidelijk een verschil tussen de verhoudingen met grote vaste leveranciers en klanten en de meer 'wisselende contacten', zoals bij enkele Belgische bedrijven.

Het inschakelen van een advocaat en procederen in verband met klachten zijn in de relaties met grote leveranciers en klanten - ook in Duitsland - doorgaans een zeldzaamheid.

"[Als er een gebrek is geconstateerd] dan wordt nagegaan of we met het gebrek kunnen leven. Zo ja, dan proberen we bij de leverancier de prijs te drukken. Zo nee, dan moet de leverancier de waren terugnemen. Meer alternatieven zijn er niet. We hebben gelukkig nog niet meegemaakt dat we tegen een leverancier gerechtelijke stappen moesten ondernemen. [En het inwinnen van juridisch advies?] Zeer zelden. De advocaat erbij halen is de laatste 5 jaar 3 of 4 keer gebeurd. Die halen we er alleen bij als we weten dat we in ons recht staan: de leverancier wil eenvoudig niet. Dat is zeer zeldzaam. Wij proberen van te voren met de leverancier altijd persoonlijk in het reine te komen voordat we keihard zoggen we gaan er juridisch tegenaan." (Rein, D)

"Vroeger kwam bet wel voor dat er kwaliteitsverschillen in de leveringen waren. $\mathrm{Nu}$ is dat niet meer zo. Toen was het vooral met PVC dat we 1 a $2 \%$ slechte waren hadden. En die werden dan geruild. Je ziet het direct aan het product dat je er niet aan hebt. Dan wordt de technicus erbij gehaald. Die geeft zijn oordeel en dan wordt de lading zonder bezwaar geruild. Leveranciers zijn daarvoor verzekend en wij ook tegenover onze klanten wanneer er flessen kapot zouden gaan. Dan wond de schade automatisch vergoed. Dat je daarvoor naar het gerecht zou moeten, kennen wij niet, dat zoiets noodzakelijk zou zijn." (Flasche, D) 
Alleen in sectoren waar grote aantallen klanten worden bediend, treden met name betalingsproblemen in grotere frequentie op en ziet men zich ook vaker genoodzaakt gerechtelijke stappen te ondernemen.

Zo zijn de problemen met de kleinere klanten bij Buis overwegend betalingsproblemen. Het zijn vooral aannemers en onderaannemers in de bouw die - zoals elders in dit verslag is gebleken - vaak krap bij kas zitten. Een vrij groot deel van de afzet gaat naar deze menigte (enkele duizenden) kleinere klanten die voor relatief kleine bedragen afnemen. Nieuwe klanten worden gescreend door een informatiebureau en moeten tot die tijd contant betalen. Als er een gunstig bericht afkomt krijgt de klant een kredietlimiet en dat wil meestal zeggen: betaling binnen 30 dagen na factuurdatum. De betalingen worden 'opgevolgd' in een maningssysteem. Om de veertien dagen wordt er een betalingsherinnering gestuurd tot negen weken na factuurdatum. Daarna neemt de advocaat de aanmaning over. Als er dan binnen vijf dagen nog niet betaald is wordt er een vertegenwoordiger langs gestuurd om uit te zoeken wat er aan de hand is. Als de betaling dan nog achterwege blijft, gaat de advocaat over tot gerechtelijke incasso. Alles bijeen zorgen deze activiteiten voor veel werk. Om de veertien dagen worden er ruim duizend aanmaningen in enveloppen gestoken en verstuurd:

"Van die aanmaningen zijn er tot de brief van de advocaat een 50-tal over. Van die 50 gaan er [na de brief van de advocaat] misschien 45 betalen en blijven er 5 over waarvoor we de advocaat inschakelen; die worden gedagvaard. Op jaarbasis misschien een 50-tal. Maar ja, dat komt omdat we met zoveel klanten zitten." (Buis)

Het is een procedure die veel gelijkenis vertoont met de incassotrajecten van bedrijven die te maken hebben met grote aantallen particuliere debiteuren.

Ook bij Markies (B) zijn er betalingproblemen. Die zijn er vooral in de sector van de vakhandel. In de projectensector dekt men zich goed in omdat het daar meestal om grote bedragen gaat. Als er slechte informatie is over een klant wordt er een bankgarantie gevraagd. De betalingstermijn van 60 dagen wordt wel vaak overschreden, desnoods wordt gedreigd met het stopzetten van het project, maar uiteindelijk wordt er toch betaald. Dat ligt anders bij de vakhandel. Het gaat in deze sector meestal om kleinere bedragen, maar ook daar wordt de betalingstermijn regelmatig ruim overschreden. Deze betalingsachterstanden ontstaan vooral door seizoensinvloeden. In het hoogseizoen wordt er veel besteld en geïnstalleerd, maar de betaling kan pas volgen als de vakhandel zelf betaald is. Het probleem is meestal dat men daardoor in het hoogseizoen krap bij kas zit. De betaling wordt opgevolgd door de bekende reeks acties: eigen aanmaningen, telefonisch contact, aanmaning van de advocaat. Lopende bestellingen worden dan geblokkeerd. Jaarlijks belanden naar schatting 20 van deze zaken bij de gerechtelijke incasso.

Min of meer dezelfde problematiek tekent zich af bij Plaat. Ook daar zijn nogal eens betalingsachterstanden, meestal kleinere bedragen die men tegoed heeft 
van dakdekkers. Maandelijks gaan er 5 tot 10 vorderingen naar de advocaat, maar meestal wordt er daarna betaald. Een gerechtelijke procedure komt een enkele keer per jaar voor. Het voeren van zo'n procedure laat men dan meestal aan de advocaat over.

\section{Hoofdaannemers in de Duitse en Belgische bouwnijverheid: verschillende structuren en calculaties}

De beantwoording van de vraag of de verschillen in de 'kosten' van gerechtelijke stappen van de drie landen van invloed zijn op het gebruik van methoden om klachten te voorkomen en op het vermijden van geschillen is voor de aannemers in de bouwnijverheid ingewikkelder dan voor de kunststofverwerkende bedrijven. In ieder geval is in deze branche de kans op klachten en geschillen groter dan bij de kunststofverwerkende bedrijven; en in de bouwnijverheid is het doen van juridische stappen zeker een optie bij het omgaan met dreigende geschillen met leveranciers en klanten. Dat bleek in Nederland het geval te zijn en ook in Duitsland en België is het in grote trekken niet anders.

Het is gebleken dat het in Nederland in hoge mate gebruikelijk is dat men in het geval van 'discussies' besluit tot het voorleggen van de kwestie aan de arbiters van het Arbitrage-instituut in de bouw. Deze procedure is betrekkelijk kort (ongeveer een jaar volgens de respondenten). Het meest tijdrovend is een procedure in Belgiè. Respondenten klagen over termijnen van 5 tot 10 jaar. Duitsland bevindt zich volgens respondenten tussen deze uitersten in. Het is de vraag of deze institutionele verschillen tussen Duitsland en België ook aanleiding geeft tot andere keuzes dan het geval is in Nederland.

Een eerste conclusie is: in ieder geval blijkt het juridisch institutionele verschil tussen België en Duitsland niet duidelijk tot verschillende afwegingen van aannemers te leiden. In beginsel vinden aannemers in België en Duitsland de tijd die een gerechtelijke procedure kost te lang om er veel toe over te gaan. Of dat nu drie jaar is of langer maakt niet zoveel uit. Het is allebei te lang. Zolang kunnen de meeste aannemers niet op hun geld wachten. We stuiten hier op een belangrijk onderdeel van de 'logica van het ondernemen' in de aannemerij: het project legt beslag op financiële middelen van de aannemer; in verband met nieuwe opdrachten is het van belang het geld er snel weer uit terug te krijgen. Het geld moet snel circuleren en als het te lang blijft hangen in projecten kan de continuïteit van het bedrijf in gevaar komen.

Een tweede conclusie is dat deze logica ook weer niet altijd even dwingend blijkt te zijn In sommige gevallen nemen sommige aannemers, mogelijk vooral degenen die over een solide financiële basis beschikken, bewust om commercięle 
redenen het risico van het ontstaan van een geschil. Zoals bijvoorbeeld wanneer de aannemer inschrijft met een afgeslankt bestek en de winst uit het meerwerk tracht te halen. Daarmee wordt de kans vergroot op onenigheid met de opdrachtgever die tijdens de loop van het project voor (soms aanzienlijke) onverwachte kosten komt te staan. Soms laat men een geschil rustig escaleren omdat het financieel niet onaantrekkelijk is. Zoals bijvoorbeeld bij de aannemers die de wettelijke rente wel aantrekkelijk vinden die over de looptijd van een procedure over het gevorderde wordt berekend.

\subsection{Leveranciers van bouwmaterialen}

\subsubsection{Preventie van klachten}

\section{A) Duitsland}

De verhoudingen met de toeleveranciers van bouwmaterialen worden door alle respondenten als harmonieus gekenschetst. Dat is naar men zegt vooral het resultaat van selectie en concentratie van bestellingen.

Bij de selectie van leveranciers wordt in de eerste plaats leveringsbetrouwbaarheid als het belangrijkste criterium aangewezen. Als niet punctueel wordt geleverd, moet het werk worden stilgelegd en dat veroorzaakt schade. En in de bouw wordt dergelijke schade snel grote schade, niet alleen omdat de werknemers dan improductief zijn, maar met name ook omdat een vertraging een ketting van (vertragende) gevolgen kan hebben op het verdere verloop van het project. De leveringsbetrouwbaarheid wordt in de praktijk getest. Er komen geen informatiebureaus aan te pas. Wie op grond van de ervaringen niet voldoet valt af. Bij Alsdorf wordt daarbij de ISO-procedure gevolgd (lijst van geaccepteerde leveranciers, evaluatie, selectie), bij de anderen spelen vooral de bouwleiding en de afdeling inkoop een belangrijke rol bij de selectie. Daarnaast moet de prijs in orde zijn. Wie betrouwbaar is en een goede prijs heeft kan een vaste leverancier worden.

Blijkbaar loont het dan ook de moeite om bestellingen te concentreren; in de eerste plaats omdat bij een groot volume de prijs 'bespreekbaar' wordt en in de tweede plaats omdat vaste afnemers op extra égards kunnen rekenen.

"... het heeft ook als groot voordeel dat een leverancier die ons reeds decennia bedient, ook voor een zak cement met de vrachtwagen naar de bouwplaats komt gereden. Iemand bij wie we nog niets gekocht hebben zal zeggen: voor éen zak kom ik niet, ik kom alleen voor een lading. " 8 (Alsdorf)

8 Direct aansluitend schetst hij de schaduwzijde van deze werkwijze: "Het heeft ook nadelen. Als ze elkar veel buiten het werk zien, dan wordt het oppassen dat de leveranciers niet teveel geld krijgen." (Alsdorf) 
Een en ander kan resulteren in langdurige relaties. Alsdorf noemt een relatie met een leverancier die al meer dan twintig jaar bestaat. Met een andere leveranciet doet men al vijftien jaar zaken. Ook Birk gewaagt van langdurige relaties. De overige zegslieden geven aan in hoofdzaak met beproefde leveranciers te werken.

Daarbij is de concentratie van bestellingen soms zeer groot. De zegsman van Hitfeld geeft aan dat ruim $60 \%$ van de bestellingen bouwmaterialen door de firma naar een enkele leverancier gaan. Het klinkt logisch dat een toeleverancier voor dergelijke klanten zijn best doet. De zegsman van Alsdorf spreekt dan ook over afhankelijkheid:

Die zijn van ons afhankelijk. We kopen veel beton, stenen, mortel, ijzer en zij doen in het algemeen hun uiterste best om ons voorkomend en correct te behandelen. Geen klachten. [... .... men kent elkaar en zij willen hun klanten niet verliezen. Wij zijn voor hen vaste opdrachtgevers. (Alsdorf)

Het lijkt hier dus vooral te gaan om wederzijdse afhankelijkheid: de aannemer is aangewezen op een leveringsbetrouwbare leverancier, de leverancier heeft graag vaste en grote afnemers. Dat wil zeggen: als ze goed betalen. Dat is volgens de zegsman van Stolberg de beste manier om de relatie vrij van fricties te houden: nauwgezet betalen. Andere elementen die in dat verband door sommigen worden genoemd zijn: persoonlijk contact en 'goed partnerschap'. Voor Birk is persoonlijk contact van belang:

Niet altijd met de chefs; maar met degene die het werk doet, die als aanspreekpunt fungeert. Als ik een probleem heb en ik kan niet verder dan sturen ze iemand of een adviseur van de fabrikant. Dat functioneert hier in Duitsland zeer goed. (Birk) Hij gaat er regelmatig langs, ook om te horen of er nog nieuwe producten op de markt zijn gekomen. Stolberg daarentegen zegt aan persoonlijke bekendheid minder belang te hechten. Doorslaggevend is hoe adequat "je behandeld wordt". Dat is voor hem een selectiecriterium.

Daarnaast noemt de zegsman van Birk het belang van 'goed partnerschap'. Dat houdt in dat als er problemen rijzen (over leveringen of betaling) daarover door beide partijen open gesproken kan worden.

Dan heeft men de minste problemen. Als ik materiaal bestel en hij kan niet leveren dan moet hij mij dat zeggen: "het gaat niet, ik heb het niet, ik heb het dan en dan". Daarnaar wordt ons personeel ingepland. (Birk)

Contractuele elementen spelen een ondergeschikte rol in het voorkomen van problemen. De orders aan de leveranciers zijn sober, bevatten uitsluitend essentiele informatie (over de kwaliteit en de hoeveelheid van het product en verder tijd en plaats van levering). Offertes, orders en orderbevestigingen worden doorgaans via de fax verstuurd. Dat verkleint naar men zegt de kans op misverstanden. Bij telefonische afspraken - de voorheen gebruikelijke werkwijze - treden die gemakkeliiker op. 


\section{B) België}

Bij de levering van grondstoffen doen zich volgens de aannemers regelmatig problemen voor, maar die monden zelden uit in 'discussies' of juridische stappen. De problemen betreffen voornamelijk de kwaliteit van de materialen en in mindere mate de kwantiteit en timing van de levering. Opmerkelijk is dat verschillende annemers (met name Bilzen, Hoelbeek en Waterschei) nadrukkelijk aangeven dat ze trachten dergelijke onvolkomenheden onder controle te krijgen met methoden die een onderdeel vormen van kwaliteitssystemen zoals ISO-9000. De lijst met geprefereerde leveranciers, klachtenprocedures en de jaarlijkse evaluatie worden genoemd als belangrijke middelen om het aantal problemen in deze relaties beperkt te houden. Men is uitgesproken quality minded.

Wekelijks worden problemen besproken en als er klachten zijn wordt er een klachtenformulier gemaakt en overgemaakt aan de leverancier. De meeste leveranciers kennen dat niet, die verschieten dan wel eventjes. In België is het nog zo het traditionele familiale gebeuren in de bouw. Daar wordt dus nog wel degelijk aandacht aan besteed. En op ons lorder]formulier staan dus ook altijd de klachten die in het verleden zijn gebeurd: "... [de goederen] worden speciaal gecontroleerd op de volgende klachten die zijn gebeurd. "Dat is eigen aan de ISO-procedure. Sinds die invoering zijn er niet zoveel klachten. Vroeger waren die kosten er ook, maar die werden nooit geformuleerd. Dat werd opgelost, ter plaatse. Dan waren er kwaliteitskosten door die klachten, maar daar werd verder geen aandacht aan besteed. We zijn er nu vijf jaar mee bezig geweest. Het is zo dat men nog concurrenticel kan zijn. Want kwaliteitskosten, dat gaat in de meeste bedrijven zonder dat men het weet om tussen de 12 en $17 \%$ van de omzet. Daar zijn studies van. Wij zijn er in geslaagd - we hebben gepoogd dat statistisch na te gaan - dat $10 \%$ te drukken. (Bilzen)

Voor enkele producten waarvan de kwaliteit moeilijk te objectiveren is (zoals hout), is het van bijzonder belang met leveranciers te werken, op wier oordeel naar de ervaring heeft geleerd - vertrouwd kan worden.

De preventie van problemen is overigens niet de enige reden waarom een groot deel (enkelen noemen een percentage van 60 ) van de leveranciers vaste relaties zijn. Kamerlo noemt bijvoorbeeld als voordeel:

"...dat u op uw wenken wordt bediend. Want als u een grote leverancier hebt en ge zegt ik moet het nu hebben, dan zal hij eerder genegen zijn te pogen dat inderdaad te doen. Een occasionele mens, ja, die ene keer..." (Kamerlo)

Soms is de kleine kring regelmatige leveranciers het gevolg van een concentratie van de aanbodzijde van de markt. Zo heeft Hoelbeek te maken met een zeer beperkt aantal leveranciers van stalen profielen. Dat kleine aantal is het gevolg van concentratie in de Europese staalproductie. Derhalve is er een beperkte keus van leveranciers, hetgeen voor het geestesoog van de afnemers direct het kartelspook oproept: 
" $U$ kunt wel begrijpen dat die heren, aangezien ze met zo weinig zijn, nog wel een afspraken willen maken over prijzen. We merken dat hier doordat ze tot op de centime dezelfde zijn. Dan weten we hoe laat het is. En voor ons komt het er dan op aan het spelletje zo snel mogelijk te doorprikken. Als er een lost in dat systeem krijgt de prijs weer terug vrij spel." (Hoelbeek)

Het is dus de kunst zaken te doen met een beperkte kring van geprefereerde leveranciers te werken zonder dat de prijs te veel oploopt. Dat doet men door de aankopen over de leveranciers te spreiden of af te wisselen; er wordt gewaakt voor te grote concentratie van de inkopen:

"Nee, als je dat doet gaan de prijzen omhoog. We hebben de vier mensen die vast leveren, en als we een prijs gaan vragen voor iet of wat waarde, dan gaan we er een of twee mensen vreemd bijhalen om de prijs te controleren. Want anders gaan ze elkaar tegenkomen en met elkaar praten..." (Kamerlo)

Toch komt het blijkbaar wel eens voor dat men zich verlaat op een leverancier. Zo betrekt Hoelbeek betonproducten bij één enkele leverancier en bij Genk is de beslissing genomen alle stalen wandplaten waarmee de hoofdzakelijk industriële gebouwen worden bekleed bij één buitenlandse producent in te kopen. Dat heeft voor beide producten onder andere te maken met het gemakkelijker afwikkelen van klachten over gebreken. Beton is - zowel los als in prefab - een lastig product dat gemakkelijk voor problemen kan zorgen. Dan is het van belang een leverancier te zoeken die daar aan mee wil werken (en die zal daartoe des te meer bereid zijn naarmate het volume van de bestellingen groter is). De betonleverancier van Hoelbeek heeft zelfs geholpen met het schrijven van de richtlijnen voor de montage van prefab elementen. Ook bij Genk is het een afweging geweest van voor- en nadelen van een leverancier waarbij het hebben van een aanspreekpunt voor het geval er problemen ontstaan als een belangrijk voordeel wordt beschouwd. Ook daar spreekt men van een 'partnerschap':

"Het is dan een kwestie van een goede leverancier te hebben. Daar bedoel ik mee: de prijs moet interessant zijn (het moet verkoopbaar zijn), de kwaliteit moet goed zijn, eventuele probleemsituaties wat betreft kwaliteit, levertijd - daarvoor moet snel een oplossing komen. Ik denk we die nu gevonden hebben. We hebben een soort partnerschap opgericht met die mensen en dat functioneert nu heel goed. Nadeel is natuurlijk: we kunnen niet zo snel terugswitchen naar een andere leverancier. Alls is te doen uiteraard. Maar dat zullen we niet zo snel doen [...]. Of er moet iets gebeuren, een van die factoren die serieus storend gaan zijn. Als er een concurrent op de markt komt met veel lagere prijzen en toch ook een bepaalde kwaliteit kan leveren die verlangd wordt, dan wordt er natuurlijk wel gepraat." (Genk)

Met deze leverancier worden door de inkoopleider van Genk maandelijks de 'probleempjes' doorgesproken: de manier van aanleveren, de facturatie, allerlei factoren die ertoe bijdragen om de gang van zaken te vereenvoudigen, te verbeteren, te 
versnellen ("Dat kun je niet met een leverancier waar je af en toe iets koopt."). Men probeert van de problemen te leren.

Dit leereffect is een voordeel van vaste leveranciers, maar er zijn er meer zoals uit het bovenstaande blijkt. En in sommige gevallen is het onvermijdelijk. Het belangrijkste nadeel is het gevaar dat het de prijs opwaarts beïnvloedt. Dat is wat vaste leveranciers de das om kan doen en nieuwe leveranciers kansen biedt. Maar men laat een vaste relatie niet zomaar zonder meer vallen, overigens voornamelijk uit berekening. Alleen de zegsman van Bilzen noemt nog een ander element dat doet denken aan de 'good old Max' relaties van Macaulay. Hij noemt het 'traditie'. Maar daar kleven ook nadelen aan die niet meer sporen met de huidige manier van bedrijfsvoering:

"Dat was met bedrijf $X$, maar daar heb ik me stillekens van teruggetrokken, want dan durfden mijn mensen hun gedacht niet zeggen omdat ze denken: de baas kent die, dus daar mag ik dus niets van zeggen. Dat is herleid tot het minimum. "(Bilzen)

Het in huis halen van ISO-procedures kan duiden op het overschakelen van persoonlijke ('traditionele') naar meer zakelijke verhoudingen met leveranciers en klanten; en soms ook binnen het bedrijf. Een van de aannemers zegt de introductie van het kwaliteitssysteem te hebben gebruikt als breekijzer om de familiale structuur van het bedrijf te veranderen, dat wil zeggen dat de overige medewerkende familieleden de veranderingen in de bedrijfsvoering niet meer hebben willen meemaken en daarin aanleiding hebben gezien om zich uit het bedrijf terug te trekken.

Goede afspraken moeten worden voorbereid. Op de werfvergaderingen zullen de te gebruiken materialen en hun technische kwaliteiten worden voorgelegd en besproken. Mogelijke problemen kunnen dan worden voorkomen. Bilzen gaat zelfs zover leveranciers uit te nodigen op de werfvergadering zodat zij direct van de architect kunnen vernemen wat hij wil. Een consequentie van deze werkwijze is dat de aansprakelijkheid voor eventuele problemen rond de kwaliteit worden doorgeschoven naar de leverancier ("Ja, anders zijn wij degenen die de geldelijke problemen moeten opvangen van de misinterpretatie van de leverancier"). Bij Waterschei wordt ook gelet op het tijdig doen van bestellingen, dit om het vastlopen van de planning te voorkomen vanwege het niet tijdig leverbaar zijn van de benodigde materialen. Dit is iets wat bij Genk nogal eens problemen oplevert, zoals we nog zullen zien.

Verschillende respondenten onderstrepen het belang van schriftelijk vastgelegde afspraken en condities bij het voorkomen van problemen. Met name bij Bilzen wordt veel werk gemaakt van het zich 'juridisch afdekken'. Dat is een direct gevolg van de ervaringen van de directeur als lekenrechter bij de Handelsrechtbank. Het is zijn ambitie in dit opzicht misverstanden zo min mogelijk ruimte te geven, want zijn ervaring leert dat daaruit het merendeel der geschillen voortko- 
men. Interessante elementen uit de vonnissen die hij onder ogen krijgt worden in de voorwaarden opgenomen. Bij de anderen staat de explicitering van afspraken en condities minder op de voorgrond, maar bijna allen menen dat het expliciteren van afspraken, met name wat betreft essentialia als de prijs, levertermijn en productkwaliteit, problemen voorkomt. Waar mogelijk wordt gebruik gemaakt van normen voor productkwaliteit. Jaarcontracten worden door deze aannemers weinig afgesloten. Enkelen hebben een jaarcontact voor mortel. Voor het overige wordt er per project besteld.

De laatste mogelijkheid om problemen rond de grondstoffen te voorkomen is bij de bezorging en verwerking op de werf of de werkplaats. Afgeleverde bestellingen worden ter plaatse door de verantwoordelijke integraal of steekproefsgewijs gecontroleerd, voorzover dit althans mogelijk is. Bij Hoelbeek bijvoorbeeld kunnen eventuele mankementen pas worden geconstateerd bij de verwerking:

"Wij zetten wel een stempel op de bon dat we de levering aanvaarden behoudens aantallen en fouten of mankementen. Als er dan iets scheelt merken we dat bij de eerste bewerking. ${ }^{9}$ Die stempel op die bon is ingevoerd in het kader van ISO-9000.

En als die stempel er niet op zou staan? Dan riskeren wij dat we iets getekend heb-

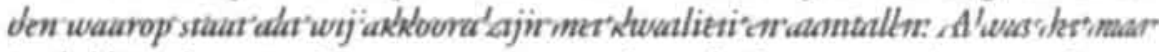
in de kleine lettertjes. Dan moet je weer een hoop druk gaan uitoefenen via de commerciële relatie en ons gewicht als klant, om het weer rechtgezet te krijgen." (Hoelbeek)

\subsubsection{Omgaan met klachten in de relatie met leveranciers}

\section{A) Duitsland}

Er komen in deze verhoudingen met leveranciers van bouwmaterialen - daarover zijn de respondenten het duidelijk met elkaar eens - betrekkelijk weinig problemen voor die aanleiding geven tot klachten. En als er klachten zijn dan worden die in onderling overleg opgelost. Men geeft aan dat conflicten uiterst zeldzaam zijn. Het inschakelen van een advocaat of het ondernemen van gerechtelijke stappen komt vrijwel niet voor in deze relaties.

\section{B) België}

Problemen rond de leverantie van bouwmaterialen komen voor: de materialen vertonen met enige regelmaat gebreken, ze worden wel te laat afgeleverd, er wordt soms te weinig geleverd. Maar men geeft meestal aan dat de omvang van de pro-

9 Overigens komen deze specifieke problemen zelden voor (150 vrachtwagens met proficken. 2 problemen). 
blematiek in dit deel van de bedrijfsvoering niet erg groot is en bovendien dat de gesignaleerde problemen overwegend in overleg met de leverancier uit de wereld worden geholpen.

Dat wil uiteraard niet zeggen dat de aannemer (als klant van de leverancier) altijd zonder slag of stoot in alles zijn zin krijgt. Het moet wel duidelijk worden dat de leverancier aansprakelijk is voor de tekortkoming. Duidelijke afspraken bewijzen dan hun waarde. De zegsman van Hoelbeek schetst de gang van zaken rond (regelmatig) voorkomende problemen bij betonelementen als volgt:

"Als wij fouten bebben gemaakt draaien wij daar voor op. Maar het is altijd terug te vinden. En als het gevonden is, is die leverancier weer correct in zijn afhandeling. Maar overuren, niet controleerbare zaken, wachturen, daarover krijgen we dan toch wel wat geëmmer." (Hoelbeek)

De soepele afhandeling van klachten is waarschijnlijk terug te voeren tot de selectie van leveranciers. Waar het kan, zijn deze bedrijven selectief ten aanzien van hun leveranciers en de wijze waarop problemen worden opgelost is een van de selectiecriteria. Er wordt geselecteerd aan de hand van ervaringen. De zegsman van Waterschei schetst de gang van zaken in het geval er minder aan bouwmaterialen op de bouwplaats wordt afgeleverd dan was afgesproken:

"...de procedure is: er wordt gebeld, eerst vanaf de werf. Krijgt die het niet opgelost, dan is aankoop aan de beurt. Krijgt die het niet voor elkaar dan wordt er door het hoofd van de verkoop, dus eigenlijk vanuit de directie, een aangetekend schrijven gestuurd. Maar tegen die tijd is het probleem meestal opgelost. Want onze leveranciers die selecteren zich dan vanzelf. Als dat gebeurt met een betonvloer, en ge merkt bij iedere mixer die komt - dat is een hoeveelheid die ge eigenlijk niet juist kunt berekenen; dat wordt per zes kuub geleverd - stelselmatig dat ge net niet toekomt met die zes kuub, ook al rekent $u$ dat het met zes kuub moet uitkomen, dan wordt er al eens een briefje geschreven. ${ }^{10}$ Maar die selecteert zijn eigen als die er niet op ingaat. De keren nadien, als dat twee of drie keer gebeurt, dan gaat die gewoon van de lijst. Daar is concurrentie genoeg in. Iets wat exclusief op de markt is, dan is het wat anders, dan staat u wat zwakker. Maar met zoiets sta je als aannemer redelijk sterk." Waterschei)

De selectiecriteria worden bij al deze bedrijven tot uitdrukking gebracht in een van de procedures van het kwaliteitssysteem. Maar ook zonder ISO zal het op dit punt niet wezenlijk anders gaan.

10 Mogelijk is het voorbeeld enigszins theoretisch, want van een andere aannemer begreep ik dat het afvullen van mixers meestal computergestuurd geschiedt. 


\subsection{Onderaannemers}

\section{A) Duitsland}

Er wordt door de respondenten weinig geklaagd over onderaannemers. Volgens de statistieken wordt in Duitsland een kleiner deel van de bouwproductie in onderaanneming gerealiseerd. ${ }^{11}$ Een oorzaak van dit verschil op het vlak van de onderaanneming met de situatie in Nederland en België is waarschijnlijk dat aannemers in Duitsland vaker projecten uitvoeren met eigen personeel. Dat is met name mogelijk door het bouwproces anders te organiseren. In Duitsland wordt vaak (meer dan in Nederland en België) gewerkt met wat 'nevenaanneming' genoemd wordt. Daarbij wordt het project in onderdelen gesplitst en aan verschillende aannemers aanbesteed die zich ieder voor hun deel van het project met de opdrachtgever te verstaan hebben. ${ }^{12}$ Vooral in de Tiefbau (grond-, wegen waterbouw) - zoals bij Birk, Hitfeld en Alsdorf - en in de ruwbouw (zonder afwerking) - zoals bij Stolberg en Alsdorf - kan men op die manier veel zonder onderaannemers doen. Volgens de zegsman van Hitfeld speelt bij het mijden van onderaannemers door zijn firma ook de angst voor de zwartwerk problematick een rol. Dit is een gevoelig punt en kan voor enkele respondenten een reden zijn geweest om over dit onderwerp minder mededeelzaam te zijn.

Onderaannemers komen echter wel te pas bij de bouw van kant en klare fabriekshallen/bedrijfsinstallaties en bij woningbouwprojecten. Maar deze relaties worden niet afgeschilderd als een belangrijke bron van klachten. Waarschijnlijk speelt daarbij een rol dat men het zich in de huidige omstandigheden kan permitteren kieskeurig te zijn:

I: In Nederland is dit een bron van problemen. Hoe verloopt dat bij U?

$R$ : Dat was bij ons ook het geval. Jaren hadden we er problemen mee. Maar in de loop der jaren - ook omdat we steeds hetzelfde bouwen - hebben we die [onderaannemers] geselecteerd met wie het loopt. Of ik nu materiaal inkoop of diensten, dat gaat precies hetzelfde. Als het niet functioneert, dan neem ik hem niet meer [als onderaannemer]. En na verloop van tijd heb je onderaannemers waarmee het functioneert. (Koslar)

\section{B) België}

De relaties met onderaannemers in België zorgen doorgaans voor meer problemen. De voornaamste oorzaak is dat het overwegend gaat om kleine bedrijfes:

11 Schellevis e.a. (1995) De Nederlandse bousv, p. 23; al zijn die verschillen nu ook weer niet heel erg groot; de percentages voor de Nederlandse en Duitse bouwproductic zijn: 25\% resp. $20 \%$. 12 T.a.p., p. 38. 
"In de afwerking heb je twee soorten onderaannemers: de grote afwerkingsbedrijven; die zijn niet geïnteresseerd in onze soort activiteiten; die gaan liever zelf rechtstreeks aannemingen afsluiten bij banken, winkelbedrijven e.d. Dat maakt dat wij bij de kleinere terechtkomen en daar moet dan vraagtekentje bij als het gaat om hun interne organisatie, planning, hun kwaliteitsbesef, de kwaliteit van hun mensen. Daar zit volgens mij de grote oorzaak." (Hoelbeek)

"Het blijven bouwvakkers. Die houden niet zo van dingen op papier, dat is hun vreemd. Die is al blij als de vrouw hun een factuur kan maken. Maar om een planning op te stellen, planningslijsten: kennen ze niet. Een kleine zelfstandige heeft niemand op kantoor zitten." (Genk)

Maar de berichten klinken iets minder alarmerend dan in Nederland. Mogelijk is dat het gevolg van het feit dat bij deze groep aannemers ook de kleinere zeer uitgesproken kwaliteitsbewust zijn: er worden expliciete en precieze afspraken gemaakt en er wordt geëvalueerd en geselecteerd. De zegsman van Bilzen zegt dat er bij zijn bedrijf vroeger op dit vlak meer problemen waren, omdat alles verliep via mondelinge afspraken. Maar dat wordt tegenwoordig anders aangepakt:

"... wij maken hun papieren op en ze moeten dat tekenen. Ze weten dat wij communicatief zeer goed zijn ten opzichte van hun juist te definiëren wat ze moeten doen. We geven ze de mogelijkheid problemen te voorzien. Hier wordt veel aandacht besteed aan de voorbereidende negotiatie tot het contract werkelijk ondertekend wordt. Alles wordt doorgepraat. Wij proberen ons in de plaats van de onderaannemer te stellen: wat moet ik weten om het goed te laten lopen. En de wet van Murphy, die komt toch. Wij proberen alles duidelijk te maken aan de onderaannemer voor hij begint. Dan heb je later ook weinig problemen van "dat wist ik niet". Dat is het probleem van de communicatie." (Bilzen)

$\mathrm{Hij}$ is er stellig van overtuigd dat deze werkwijze het aantal problemen sterk heeft gereduceerd. Daarnaast is ook van belang dat men ervaring opdoet met wat de onderaannemer kan:

"We werken met stalen. Het contract voorziet: als je voor het eerst komt werken zijn de eerste 14 dagen op proef. Voldoet hij niet, ja dan... Dan wordt het vrijdags bekeken. Is hij goed, dan komt hij op de lijst en kan hij verder werken. Zo niet, dan wordt zo snel mogelijk getracht van hem af te komen. Zelfs in de loop van het werk. Als ge problemen gaat ontdekken, dan gaan ze komen. Maar er zijn contracten waar je niet onderuit komt. Dan wordt op die man heel speciaal toezicht uitgeoefend." (Bilzen)

"We hebben beoordelingssystemen, ook met onderaannemers....een maal per jaar worden ze geëvalueerd. De evaluatie gebeurt door de mensen die met ze werken, dus van de uitvoering, en altijd door de mensen van de aankoop. En dan wordt er een globaal cijfer gegeven...om te zien of er verandering moet komen in de samen- 
werking. En degenen die op de zwarte lijst moeten komen, komen à la minute op de zwarte lijst, voor het jaar voorbij is, die vliegen er gelijk uit." (Hoelbeek)

Dat is wat iedereen probeert te doen: het selecteren van betrouwbare onderaannemers. Meestal is dit overigens ook een standaardonderdeel van ISO-9000. Met het merendeel van de onderaannemers doet men regelmatig zaken. Dat heeft ook nog een ander voordeel, zeggen verschillende aannemers:

"[We] proberen met een langere relatie te werken want als je een eenmalige ondernemer hebt op de werf waar je gedonder mee hebt, dan gaat het tot het uiterste. Heb je iemand waar je 10 a 20 miljoen frank onderaanneming mee hebt, dan kan je via de volgende projecten toch weer druk uitoefenen om het vorige op te lossen." (Hoelbeek)

Ook enkele andere aannemers maken gewag van dit extra voordeel van de duurzame relatie met onderaannemers. Alleen Bilzen geeft aan nog een ander middel (dat we ook al bij de Nederlandse aannemers tegenkwamen) aan te wenden om onderaannemers aan zich te verplichten: de vlotte betaling. Dit is minder ruimhartig dan het lijkt want naast goodwill levert contante betaling ook een aantrekkelijke korting op.

Ondanks alle voorzorgsmaatregelen zijn er toch regelmatig problemen op het front van de onderaannemers. Een belangrijke categorie problemen heeft betrekking op wat men noemt 'timing': de onderaannemer komt op het geëigende tijdstip niet opdagen. Het kan zijn dat de oorzaak bij aannemer zelf ligt doordat de bouw vertraging heeft, zodat de onderaannemer op het afgesproken tijdstip niet aan de slag kan. Als hij dit gat opvult met ander werk, kan het zijn dat hij op het moment dat het wel uitkomt geen mensen meer vrij heeft. Het kan ook zijn dat de onderaannemer gewoon te veel hooi op zijn vork neemt.

"We hebben eigenlijk niet zo heel veel problemen. Behalve de laatste tijd met een onderaannemer die al onze houten deuren zou doen. In een bepaalde periode vielen er zoveel werven tegelijk, die man kon het niet bolwerken. Die zei tegen iedereen: ik kom morgen. Maar dan kom je jezelf togen. Dan moet je zeggen: volgende week kan absoluut niet. Toen hebben we gezegd: zo gaat dat niet meer. Voor al die dingen moeten we minimaal twee onderaannemers hebben. Zodat ge gemakkelijk kunt omswitchen." (Genk)

"We hebben hier een planning. Mensen worden op de hoogte gehouden. Dan doen ze toch nog een toezegging aan een ander. Dan laten ze ons wachten. Dan is het de grote baas die moet bellen. In ons contract staat dat als zij na een aangesekend schrijven niet aanwezig zijn, mogen wij iemand anders aanstellen onder aftrek van de meerprijs op hun lasten. Als het geld gaat kosten wordt er meestal bijgebeend. (Bileen)

In alle gevallen wordt het de onderaannemer zwaar aangerekend als hij nalaat zijn verhindering aan te kondigen ("laat ons in de steek"). Dat is een ernstige zonde 
want daardoor kan de planning volledig in het honderd lopen en resulteren in een aanzienlijke vertraging die weer uitloopt op een boete van de bouwheer.

"Te laat is heel frequent. Slechte manieren ook. Ik bedoel: zeggen dat ze morgen gaan en er komt dus niemand. En men verwittigt dus ook niemand. Daar kunnen we van door het dak gaan. En die vinden dat dan 'normaal', dat is hun bedrijfscultuur." (Hoelbeek)

"...of hij van goede wil is kun je zien. Als hij voldoende op tijd zegt: wij kunnen niet maandag maar pas op woensdag, dan kun je dat inlopen. Maar iemand die niks zegt en hij komt niet op maandag, maar op vrijdag, ja dat is een ander verhaal." (Kamerlo)

Ook rond de kwaliteit van het verrichte werk doen zich wel problemen voor. Soms houdt men de vinger aan de pols:

"Elke onderaannemer moet na het beëindigen van zijn werk een opmetingsbon laten maken door de werfleider, die ze samen opnemen. Op die opnemingsbon moet vermeld worden of de werken correct zijn uitgevoerd. Of ze lossen het direct op en anders moet gekeken worden of de klant het accepteert. In de bouw loopt altijd wel iets mis, soms is dat niet op te lossen. Dan zal er over een prijsvermindering moeten worden gesproken." (Genk)

Als door het doen of laten van de onderaannemer tijdens de bouw problemen ontstaan probeert men ze op tal van manieren op te lossen: er worden ernstige gesprekken gevoerd over de toekomst, er wordt gescholden, er worden "juridische brieven' geschreven door de huisadvocaat, er wordt gedreigd met extra kosten. Meestal draait de onderaannemer dan wel bij. Lastiger is het wanneer het probleem aan de orde komt als het werk bijna klaar is of voorlopig is opgeleverd:

"...de problemen die we krijgen, die krijgen we na de voorlopige oplevering. Als iedereen betaald is en alles onder de voeten uit is. Na een jaar stelt men links en rechts iets vast. Dat is dan het probleem." (Waterschei)

"Soms is het dus zo dat die man voor $90 \%$ betaald is voordat het probleem eigenlijk kenbaar wordt. Iemand die middenin de planning onderaannemer is geweest, wordt dus aangerekend aan de klant, hij rekent ons aan, de klant betaalt aan ons en wij betalen aan hem. Maar terwijl de werf naar zijn einde gaat komt er betwisting over dat onderdeel van het werk en gaat de klant inhouden op andere onderdelen. Dat is natuurlijk ook niet allemaal legaal, maar zo gebeurt het. "(Hoelbeek) Soms komt men dan tot een vergelijk (al dan niet middels advocaten), maar vooral als er grote bedragen in het spel zijn kan het op procederen uitdraaien. Daarvan zullen zo dadelijk nog enkele voorbeelden ter sprake komen.

Dergelijke problemen met onderaannemers worden door de aannemers als frustrerend ervaren en niet alleen omdat ze er geld bij inschieten, maar ook omdat ze afbreuk doen aan de tevredenheid van de klant. En juist klanttevredenheid staat bij een ISO-gecertificeerd bedrijf hoog in het vaandel. Duidelijk is dat het 
geval bij een bedrijf als Hoelbeek, dat niet geruggensteund wordt door een solide reputatie van generaties her:

"Alleen blijf je dan zitten met dat enge gevoel van die ergernis op het einde van de werf. Terwijl het tot dan toe allemaal prima gelopen is. En in feite moeten wij onze nieuwe projecten krijgen van de mondelinge publiciteit van onze klant bij een nieuwe klant. Dus wij vinden dat absoluut niet goed. Maar goed, op een gegeven moment wordt daar de spons over geveegd. De uitzonderingen gaan hoe dan ook naar de rechtbank. En de uitzonderingen die naar de rechtbank gaan, dat zijn dan toch dikwijls serieuze bedragen." (Hoelbeek)

\subsection{Opdrachtgevers}

\section{A) Duitsland}

Duidelijk sombere geluiden klinken er over de relatie met de opdrachtgevers. Daaraan zal niet vreemd zijn dat de situatie op de bouwmarkt al enige jaren weinig rooskleurig is. Als de opdrachten schaarser worden, neemt de concurrentie toe en de marge derhalve af. Daarbij zegt men ook de concurrentie te ervaren van buitenlandse firma's (met name uit Zuid- en Oost-Europa), die beduidend lagere loonkosten hebben dan de Duitse firma's. Elke hapering in de betaling wordt onder deze omstandigheden scherp gevoeld door de aannemer, want het legt beslag op de financiële middelen die hard nodig zijn om de onderneming draaiende te houden.

Een deel van de problemen wordt veroorzaakt door de gemeenten, belangrijke opdrachtgevers voor de grond- weg- en waterbouwprojecten (Tiefbau). De gemeenten in de regio kampen met krimpende budgetten en volgens verschillende respondenten vangen zij een deel van de financieringsproblemen op door de betaling van verrichte werkzaamheden uit te stellen. ${ }^{13} \mathrm{Er}$ worden betalingstermijnen genoemd van 90 tot 100 dagen, wat voor Duitse begrippen erg lang is. Bedrijven die veel in deze sector werken (zoals Birk en Hitfeld) zitten dan in een moeilijk parket. Het zijn vaste klanten die men weliswaar niet graag wil verliezen door niet-inschikkelijke reacties op de betalingsvertraging, maar de trage betaling legt wel een beslag op de schaarse financiële middelen. Met name in deze sector worden problemen gesignaleerd in verband met meerwerk. Omdat de bodemgesteldheid soms onverwachte verrassingen oplevert, moeten er soms extra kosten gemaakt worden om het werk te voltooien. Als dan niet direct het werk wordt stilgelegd en alles precies wordt overeengekomen en schriftelijk vastgelegd, kan de opdrachtgever daarin later een aanleiding vinden om een gedeclte van de rekening

13 Deze krimpende budgetten worden in verband gebracht met een reallocatie van middelen ten gevolge van de Duitse eenwording. 
niet te voldoen. Enkele van dergelijke voorvallen worden gerapporteerd door Birk. Ook Alsdorf geeft aan dat er regelmatig problemen over meerwerk zijn.

Een ander type problemen waarover men klaagt wordt door een van de respondenten treffend geschilderd:

"Er wordt wel gezegd: onze klanten kennen drie vormen van financiering; met eigen kapitaal, met vreemd kapitaal en met wanbetaling. Ze zoeken net zolang tot ze iets vinden dat niet $100 \%$ perfect is en dan zeggen ze: daarvoor is geen geld tot het gecorrigeerd is. Maar er zijn van die dingen die niet te corrigeren zijn: wanneer een muur wat scheef is kan men niet het halve gebouw afbreken. En dan blijf het bedrag betwist. " (Alsdorf)

De zegsman van Alsdorf situeert dit type problemen vooral bij niet-routiniers, zoals particulieren. $\mathrm{Zij}$ verwachten - naar zijn ervaring - van een bouwwerk dezelfde kwaliteit als van een auto: zo goed als perfect. En als er dan iets niet helemaal volgens verwachting is, wordt de laatste tranche van de rekening niet voldaan. Een dergelijke werkwijze kan uiteraard ook gevolgd worden - zoals al eerder is gesignaleerd - door meer professionele opdrachtgevers die krap bij kas zitten. Men ziet zich dus ook in deze sectoren geconfronteerd met betalingsproblemen, waarvoor men onder de gegeven omstandigheden extra kwetsbaar is.

In de interviews komen in ieder geval twee herkenbare (en soms gecombineerde) reacties op deze omstandigheden duidelijk naar voren. (1) Verschillende aannemers hebben hun activiteiten aan de veranderingen aangepast door inkrimping en/of specialisatie. Onder de gegeven omstandigheden worden minder renderende opdrachten verworven, wat noodzaakt tot afslanking. Birk, Koslar en Alsdorf hebben het personeelsbestand gedurende de afgelopen jaren sterk gereduceerd. (2) Daarnaast ziet men heil in het zich concentreren op - wat de betaling betreft risicoarme sectoren of projecten. Zo heeft Birk zich meer toegelegd op onderhoudswerkzaamheden die contant (dat wil zeggen binnen 10 dagen na facturering) betaald worden. Voorts zijn vanuit dit oogpunt ook de industriële 'turn key' projecten interessant. Koslar heeft zich toegelegd op industriële standaardprojecten van kapitaalkrachtige klanten, vooral tankstations en wegrestaurants. Daarnaast bouwt Koslar particuliere woningbouwprojecten in eigen beheer en verkoopt ze zelf ("we maken het dan liever zelf dan voor een ander die niet betaalt"). Diverse andere activiteiten van de firma zijn afgebouwd. Stolberg was al gespecialiseerd in industriebouw, en zegt niet meer problemen te hebben dan anders. Alsdorf heeft de laatste tijd een aanzienlijk deel van het personeel afgestoten, overigens zonder echt in een bepaalde sector te specialiseren.

Overigens worden andere methoden om problemen te voorkomen niet vergeten. Met name bij Alsdorf wordt het belang van een kritische bestudering van het bouwplan onderstreept. De bouwcontracten worden grondig doorgenomen, want ogenschijnlijk kleine details kunnen grote gevolgen hebben 
"In Duitsland komt het voor: dan komt de architect en die geeft de ene opdracht na de andere, ook die kostenverhogend zijn, zonder dat hij een volmacht heefi. Dat gebeurt en de normale uitvoerder denkt: de architect leidt de bouw, die mag dus beslissen. Hij maakt van 15 garages 50 garages. Dan zegt de opdrachtgever later: er zijn er 35 teveel. Die heb je zonder opdracht gebouwd. Dat doen wij niet. Een bedrijfskundig medewerker en ik samen, we lezen zeer zonguldig de contracten. We onderhandelen ook lang over die contracten met de klant zonder advocaat. "(Alsdorf)

Deze uitdrukkelijke aandacht is een onderdeel van het systeem van kwaliteitsborging. Alsdorf is de enige Duitse hoofdaannemer met een ISO-certificaat. Anderen beamen het belang van het bouwcontract, zij het niet zo nadrukkelijk. Stolberg zegt daarentegen dat het bouwplan in zijn sector minder van belang is om problemen te voorkomen. De wensen van de klant zijn bekend en de klant weet dat het bedrijf kwaliteit levert en dan hoeft niet alles te worden opgeschreven, zo luidt de verklaring. ${ }^{14}$

Met name het - onder invloed van de huidige omstandigheden - selecteren van bepaalde opdrachtgevers en projecten wordt in verband gebracht met slechte ervaringen bij het incasseren van vorderingen via de gerechtelijke weg.

"We hebben geleerd dat we klanten moeten zoeken die correct betalen. Dat was een reactie op de ervaringen van daarvoor. Het duurt te lang. Een kleinen firma die 300.000 DM tekort komt gaat kapot als het [proces] drie jaren duurt." (Koslar) Blijkbaar sluit de afwikkeling van de betalingsproblemen via het gerecht niet goed aan op de behoeften van de bedrijven. De bezwaren die men in dat verband verder tegen het doen van gerechtelijke stappen aanvoert zal zodadelijk worden toegelicht. In ieder geval wegen deze bezwaren zo zwaar dat het voorkomen van problemen middels selectic van 'veilige' projecten en opdrachtgevers, door verschillende bedrijven geprefereerd wordt.

De specialisatic van Stolberg is niet ingegeven door de recessie want ze dateert van voor die tijd. Maar bij de keuze van de regionale 'niche' van dit bedrijf (industriebouw, met name herstel en onderhoud) was het conflictarme zakendoen naar verluidt destijds al een sterk argument. Ook de specialisaties van Hitfeld (spoorwegen, waterbouw) dateren van voor de recessie. De beperkte activiteiten in de industriebouw (ruwbouw) fluctueren bij dit bedrijf mee met de vraag en zijn op dit moment dan ook niet omvangrijk. Ook hier zijn er minder klachten over het betalingsgedrag van de industrie dan over dat van de gemeenten.

14 Mogelijk speelt hierbij ook een rol dat het bij dit bedrijf vaak om onderhoud- en herstelwerkzaamheden gaat. 


\section{B) België}

Het voorkomen van problemen in de relatie met de opdrachtgevers is moeilijk om verschillende redenen. In de eerste plaats omdat elk project anders is: het gaat in feite telkens om een uniek product. Verschillende respondenten wijzen op de invloed van het projectmatige karakter van hun productie in dat verband. Het naar wens voltooien van het product is van tal van factoren afhankelijk, die niet of niet geheel kunnen worden beheerst. We hebben al gezien dat het optreden (van de meestal per project samengestelde gezelschap) van leveranciers en onderaannemers kan resulteren in klachten van de opdrachtgevers. Dat geldt ook voor de in industriebouw gespecialiseerde bedrijven die, zoals Hoelbeek en Genk, verschillende onderdelen van het productieproces gestandaardiseerd hebben. Ook als op het werk van de leveranciers en onderaannemers niets valt aan te merken, kunnen nog onvoorziene omstandigheden voor grote problemen zorgen.

"We storten een vloer. Dit is recentelijk twee keer gebeurd. Die wordt dan vlak gestreken en binnen de 24 uur moet die dan vlak geschuurd worden, voordat hij helemaal opdroogt. Een productieproces dat in 24 uur moet gebeuren. Dat gebeurt met drie ploegen. Het is ons twee keer gebeurd, dat ze ook's nachts gewerkt hebben. Totdat ze moesten stoppen van de buren wegens lawaai. De werken moesten stilgelegd worden. Ondertussen is de beton gehard. Wij kunnen er niets aan doen. Aan de gemeente melden of zo, maar als de buren klagen dan moeten de werken stilgelegd worden. Dan is het probleem: die vloer moet zo goed mogelijk hersteld worden: afgeschuurd, polyesterlaag erop. Maar ge hebt niet die oorspronkelijk vloer die je gewild hebt. Dat kan de klant aanvaarden. Hij kan ook zeggen: ik wil die vloer niet. Dan komt ge in een dispuut, waar als beide partijen niet van goede wil zijn, dan komt ge er nooit uit." (Genk)

Voorts speelt mee dat met de klanten vaak geen duurzame relaties worden onderhouden. Wel hebben sommige bedrijven (Kamerlo en Waterschei) enkele grote bedrijven als opdrachtgevers die regelmatig terugkomen, met name in de industriebouw. Ook deze klanten hanteren een kwaliteitssysteem met de bijbehorende lijst van aanvaarde leveranciers. Aannemers met een goede staat van dienst maken zo een goede kans op vervolgopdrachten. Van deze opdrachtgevers kent de aannemer de specifieke wensen, en dat is belangrijke informatie als hij problemen wil voorkomen:

"Het eerste probleem is timing in de industrie. Die timing moet je halen. De industrie houdt je strikt aan de einddatum. Het tweede is dat u zeker aan de kwaliteitseisen moet voldoen. In feite komt het er op neer: zij mogen zelf geen problemen hebben. Het grootste probleem dat zij kunnen krijgen is dat het gebouw niet af is als de machines er zijn....Als ze die twee hebben zijn ze al een heel eind. De prijzen spelen minder een rol. Die kent men op voorhand." (Kamerlo)

Dergelijke klanten zijn goed in staat om hun wensen te (laten) expliciteren. De bestekken zijn steeds omvangrijker boekwerken, aldus de zegsman van Kamerlo. 
Bij minder ervaren en eenmalige opdrachtgevers is duidelijkheid over de wensen van de klant een gevoelig punt. Dat is de reden dat Bilzen daarbij zo weinig mogelijk onzeker wil laten. Zij omgeven het formuleren van de opdracht met veel aandacht, en nemen zonodig alle 'miserie' en paperassen van de opdrachtgever over. Dat is een onderdeel van wat hij zijn communicatieve systeem noemt:

"Dat we dus vanaf het begin bij de ontwikkeling weten wat de klant wil. We kunnen de klant begeleiden in het traject tussen ontwikkeling en afname van het product. En ook weer dat ge op de hoogte zijt: dat ge zijn behoefie kunt definiëren. En als ge dat kent, dan heb je weinig conflictstof." (Bilzen)

Het natrekken van de solvabiliteit van de kandidaat-opdrachtgever is een routinematige voorzorg (voor zover nodig). Genk vraagt een bevestiging van de bank van een verleend krediet, in het geval de investering uit een lening gefinancierd zal worden. Met betrekking tot de betalingstermijnen wordt soms een ander regime gevolgd dan in Nederland: er wordt maandelijks gefactureerd aan de hand van voortgangsstaten. De betalingstermijn is ook langer dan in Nederland: tot 60 dagen. Voor de industriebouw worden kortere betalingstermijnen genoemd (10 tot 15 dagen).

Maar desondanks zijn klachten en conflicten in de relatie met de opdrachtgever geen zeldzaamheid, zij het niet bij iedereen in dezelfde mate. Een belangrijke bron van geschillen vormt - net als in Nederland - het meerwerk. Alleen Bilzen zegt daarmee zelden problemen te hebben, dankzij - weer - zijn systeem:

"Wij blijven altijd binnen bet budget. Wil hij meer, dan nemen wij zijn rol over en dan zeggen we: dat gaat veel meer kosten, pas op. (...) Hier wordt nooit aan een werk begonnen dat niet op papier staat en getekend is. Wij moeten dus eigenlijk het budget van de klant bewaken." (Bilzen)

Maar het gaat niet bij iedereen altijd op die manier. Onvoorzien meerwerk wordt wel uitgevoerd zonder dat de opdrachtgever de prijs ervan heeft goedgekeurd omdat de bouw onder tijdsdruk staat. Het kan - volgens de zegsman van Waterschei ook zijn dat de vertegenwoordiger van de opdrachtgever (op de werf) de verantwoordelijkheid voor de goedkeuring wil ontlopen, om zich geen verwijten van de directie op de hals te halen. Als het project af is ontstaan daarover vaak 'discussies', want het kan om grote bedragen gaan. Zo meldt de zegsman van Kamerlo een geval van een door de firma gebouwde gevangenis voor het bedrag van 80 miljoen frank, waar 40 miljoen frank meerwerk bovenop kwam. Dat zijn overschrijdingen die menig opdrachtgever in financiële problemen kunnen brengen, en het is dan ook geen wonder dat over de niet geaccordeerde claims uiteindelijk stevig onderhandeld wordt. De zegsman van Kamerlo suggereert overigens ook een motief aan de kant van de aannemers om geïnteresseerd te zijn in meerwerk, zelfs als het niet is goedgekeurd: de aannemer verdient namelijk meer aan het meerwerk dan aan de initieel voorziene werken. Het aanvankelijk bestek moet concurrerend zijn, maar dat is voor meerwerk niet nodig. De klant weet dat en zal zich dan ook 
niet zonder afdingen gewonnen geven. Meestal worden dergelijke kwesties uitonderhandeld, overwegend door de werfleiding en desnoods op directieniveau. ${ }^{15}$ Maar soms lukt ook dat niet.

Problemen betreffende de betaling doen zich meestal niet voor met de grotere klanten, zoals die van Kamerlo. Wel met de kleinere klanten zoals die van Genk. Het kan zijn dat de klant de totale omvang van het project heeft onderschat:

"Wat komt erbij kijken? Dat is niet alleen het gebouw, de binnenafwerking, elektriciteit, verwarming plus het machinepark. Die totaliteit, plus de buitenafiverking wordt door de klant vaak onderschat. Het bouwwerk is maar een klein deel van het total. " (Genk)

Wanneer de opdrachtgever om die of een andere reden krap bij kas komt te zitten wanneer het werk nog gaande is, kan de aannemer als pressiemiddel de werkzaamheden stilleggen. Naar verluidt komen de problemen vooral aan het licht als het werk klaar is. De opdrachtgever heeft dan de mogelijkheid resterende betalingen uit te stellen onder verwijzing naar klachten over de kwaliteit van het product.

"De ervaring leert: als er een klant [geldelijke] problemen heeft blaast hij een technisch probleem zo hoog op. [...] Een dispuut dat een waarde heeft van een paar 100.000 frank, daar durfje hier in België rustig 3 tot 4 miljoen voor inhouden." (Genk)

Hetzelfde drukmiddel kan de opdrachtgever uiteraard ook aanwenden wanneer hij gebreken in het bouwwerk constateert die niet door de aannemer worden betwist.

"Voorbeeld: er is een stukje kunststof van een deur af. De klant zegt: "Als je dat er terug op vastmaakt is het voor mij goed. "Hij legt het in de kast. Maar dat kan dan weken duren voor het gebeurt. Je kunt daar geen advocaat voor inhuren. Dat weten [de onderaannemers] ook. Je bent afhankelijk van de goodwill van die mensen. Dat laat men te lang lopen. Dan gaat men het hebben over kleine prullen die maanden duren. Als je zo 5 of 6 prullen hebt houdt die klant met een glimlach zo 1 miljoen frank in. "Ja, maar dat is toch buiten verhouding?" zeggen wij dan. "Als je het maakt heb je morgen een cheque" zeggen zij dan. Probleem is: wij kunnen niet komen. De onderaannemer moet komen en voor hem gaat het om een veel kleiner bedrag (bijv. 20.000 frank). Die zegt "Ik zal het wel eens doen als het mij past"." (Hoelbeek)

Wanneer het om grote bedragen gaat kan ook een beperkt aantal van dergelijke kwesties het bedrijf voor grote problemen plaatsen wanneer het bedrijf niet over ruime reserves beschikt, want dan is het geld nodig voor nieuwe projecten. Hoel-

15 Volgens Kamerlo is de bereidheid om met de financiële consequenties van meerwerk akkoord te gaan bij de overheid groter dan bij de industrie. 
beek is nog bezig met het ontwikkelen van een goede strategie op dit front. Er wordt sinds kort gewerkt met kredietverzekering en gedacht over grotere betalingsvoorschotten.

Dergelijke kwesties worden soms opgelost met duwen en trekken: telefoneren, brieven schrijven, dreigen e.d. Als er betalingsachterstand is dan heeft men meestal wel een bepaalde administratieve routine waarmee men druk op de klant tracht uit te oefenen. Soms gaat het gepaard met geven en nemen:

"Dat komt altijd voor, van die kleine probleempjes die men moet oplossen. Voor kleine bedragen wordt de mantel der liefde gebruikt. Grote bedragen komen niet voor, omdat de begeleiding goed geweest is. Maar als het 50.000 frank is zwijgen we daarover. Dat is goodwill. Dat wordt in het reclamebudget gezet." (Bilzen) Maar ook in deze kwesties worden met enige regelmaat juridische stappen ondernomen.

Tenslotte komt het voor dat de planning niet gehaald wordt. Soms is dat te wijten aan de aannemer of de onderaannemer: de benodigde tijdsduur is onderschat. Het kan ook zijn dat de klant zelf daaraan deel heeft, bijvoorbeeld omdat hij om meerwerk heeft gevraagd dat niet in de oorspronkelijke planning was opgenomen. Met name in de industriebouw, met zijn korte productietijden, kan dat leiden tot problemen met wat men de 'timing' noemt. In het ergste geval komt een tijdsoverschrijding de aannemer op een boete te staan. Die loopt doorgaans met de tijd sterk op, dus hij zal zijn best doen het werk snel af te ronden.

\subsection{Concurrenten}

\section{A) Duitsland}

Met de concurrenten zijn er weliswaar weinig problemen, maar de collegialiteit lijkt op een laag pitje te staan. Er vallen geen incidentele samenwerkingsprojecten te melden, zoals in België. Naar verluidt bestaat er daarvoor op dit moment teveel 'jaloezie'. Er wordt wel melding gemaakt van duurzame samenwerkingsprojecten, zoals in verband met de aanleg van spoorwegtrajecten. Stolberg vermeldt ook een coöperatieve betonfabriek die door regionale bouwondernemingen is opgericht.

\section{B) België}

Verschillende respondenten ervaren al enige tijd een recessie in de bouw. Daarvoor houdt men enerzijds verschillende factoren aan de vraagzijde verantwoordelijk, anderzijds wordt er gewezen op grote Franse en ook Nederlandse bouwondernemingen die zich op de Belgische bouwmarkt zijn komen manifesteren met scherpe prijzen. Dientengevolge is er een sterke prijsconcurrentic, waardoor de marges onder druk staan. Bovendien wordt er, zoals een van de respondenten het uitdrukt, de bouw weinig meer 'gepraat', dat wil zeggen: er is weinig kans prijsafspraken te maken. 
Onder deze omstandigheden zoeken de aannemers naar andere middelen om zogoed mogelijk het hoofd boven water te houden. Soms kiest men voor een methode van de harde heelmeesters. Zo is bij Bilzen de personeelsbezetting drastisch teruggebracht (tot bijna de helft). Maar anderen trachten, naar verluidt, de marge elders te recupereren. De zegsman van Bilzen klaagt bijvoorbeeld over concurrenten die met zwartwerkers opereren, teneinde een lage prijs te kunnen realiseren (en dus daardoor hopen opdrachten in de wacht te slepen). En dan is er nog de mogelijkheid de aannemers en de leveranciers onder druk te zetten om de prijzen te verlagen, of om in zee te gaan met goedkopere. Maar dat kan, zoals de zegsman van Waterschei opmerkt, weer gevolgen hebben voor de kwaliteit en aldus aanleiding geven tot meer klachten.

Maar ook hier zijn de concurrenten soms weer collega's met wie goed is samen te werken. Dat gebeurt met name als een opdracht te groot is voor een ondernemer. Kamerlo noemt overigens nog enkele andere motieven voor het werken in 'tijdelijke vereniging'. Soms is dat verkieslijk als men tegen elkaar dreigt te gaan opbieden.

"...als men voelt dat men met twee heel scherp op de werf zit, dan kan men beter met iemand samen zitten en ieder de helft maken, want anders bent ge elkaar aam het doodschieten. "(Kamerlo)

En overigens wordt wel tot samenwerking besloten als men het gevoel heeft dat de opdrachtgever twijfelt tussen twee aannemers.

\subsection{Geschillen en juridische stappen}

\section{A) Duitsland}

Zoals gezegd is het risicomijdend gedrag van verschillende aannemers ten aanzien van opdrachtgevers mede ingegeven door slechte ervaringen met het innen van vorderingen via het gerecht. Eén van die bezwaren is de lange duur van een gerechtelijke procedure.

"Het gaat om de tijd die het duurt. Ook met geld. Als je al geld krijgt ben je al drie jaar ouder, omdat de gerechten zo overbelast zijn met procedures. Er zijn al kleinere firma's failliet gegaan, omdat het zolang voortgesleept heefi. Omdat men dat weet, probeert men het buitengerechtelijk af te handelen, zodat het sneller gaat. Die drie jaar kunnen voor kleine firma's dodelijk zijn als het om grote bedragen gaat. Dan zijn ze liever met tweederde tevreden dan met 100\% in drie jaar." (Koslar) "... de tijd die nodig is, duurt zo lang dat men liever andere wegen zoekt. Dat is sneller, dan kan men het vergeten, dan kan men weer rustig slapen, dan is de stress voorbij. Want het veroorzaakt veel stress om een advocaat in te schakelen, waarmee men uren en middagen teksten moet doornemen. Dus conflictvermijding komt zeker voor strijden voor het gerecht." (Alsdorf) 
Een ander bezwaar dat genoemd wordt is dat de uitkomst van een gerechtelijke procedure onzeker is. In de eerste plaats omdat de inschatting die praktijkmensen van hun rechtspositie maken niet altijd wordt gehonoreerd.

"Juristen denken anders dan praktijkmensen. Zij denken in contracten en zien aansprakelijkheidsgronden. En als het daaraan ontbreekt, kan iemand in feite gelijk hebben, maar bij krijgt voor het gerecht zijn recht niet, omdat hij geen bewijzen heeft of op een bepaald moment vergeten heeft het juiste document te verzenden. Praktijkmensen schrijven niet graag." (Alsdorf)

Hier speelt de advocaat een belangrijke rol in het inschatten van de kans op succes. Verschillende respondenten zeggen zonder een gerede kans op succes ('meer dan $50 \%$ ) aan een andere oplossing de voorkeur te geven.

Een andere bron van onzekerheid bestaat in de klaarblijkelijke voorkeur van rechters om zaken op een schikking uit te laten komen. Over deze praktijk wordt door de zegsman van Birk met enige verontwaardiging gesproken. Want de opdrachtgever kan daarop inspelen en er met een flinke korting uitspringen, terwijl het werk wel volledig gedaan is, zo luidt de redenering.

Liever probeert men er zelf uit te komen, en dat lukt blijkbaar uiteindelijk in het merendeel van de conflicten. Want het aantal gerechtelijke procedures dat respondenten opgeven is meestal gering. Birk heeft de afgelopen drie jaar twee gerechtelijke procedures gevoerd tegen industriële opdrachtgevers van grondwerkzaamheden, die bezwaren hadden tegen onverwachte kosten van meerwerk. Stolberg zegt in de afgelopen 25 jaar slechts drie gerechtelijke procedures te hebben meegemaakt. Koslar heeft op dit moment geen conflicten met industriële opdrachtgevers, maar zegt dat het tot voor kort wel voorkwam. Alsdorf heeft vooral last met klanten (zowel in de private als in de publieke sector) die de laatste tranche van de bouwsom niet willen betalen vanwege (vermeende) tekortkomingen. In de westelijke vestigingen wordt het aantal civiele procedures geschat op één per jaar. ${ }^{16}$

Alleen Hitfeld is een aannemer die frequent een beroep doet op de rechter. Elk jaar start de onderneming naar schatting drie tot vier nieuwe gerechtelijke procedures. Een specifieke oorzaak van deze frequentie is niet naar voren gekomen. Voor een deel kan de verklaring zijn dat men iets minder kritisch is bij het aannemen van nieuwe opdrachten; een gedeelte van de lopende procedures betrof faillissementen. De meeste andere zaken hebben vooral te maken met meerwerk, kwesties die in de grond- en waterbouw (de specialiteit van deze onderneming) regelmatig voorkomen

16 Terzijde wordt door Alsdorf opgemerkt dat et in de nieuwe Bondsstaten vaker geprocedeerd wordt. 


\section{B) België}

Enkele respondenten geven uitdrukkelijk aan erop uit te zijn gerechtelijke procedures zoveel mogelijk te willen vermijden. Bij Bilzen is die voorkeur te herleiden tot de opstelling van de directeur. Hij is handelsrechter en gebruikt de langs die weg opgedane kennis en ervaring om procedures te voorkomen. Hij besteedt veel aandacht aan contractuele condities - op het standaardcontract met de onderaannemers wordt aangegeven dat de firma de afgelopen 15 jaar geen enkele procedure heeft aangespannen - en vertrouwt verder op het uitvoerige 'systeem' van communicatie en begeleiding. Desnoods wil hij zijn status ook wel aanwenden om de tegenpartij te overbluffen. Ook Kamerlo geeft aan gerechtelijke procedures te willen vermijden. De standaardvoorwaarden met de leveranciers en de onderaannemers bevat een arbitrage clausule, die een eventueel verschil verwijst naar een particuliere arbitrage-instantie. Ook de zegsman van Genk geeft aan dat men de voorkeur geeft aan een gezamenlijke oplossing van een geschil:

"... we proberen het altijd snel op te lossen met de klanten. Soms lukt het. Als je genoeg van je prijs afdoet lukt heel veel. Maar hoever kun je gaan? Onlangs hebben we een probleem gehad met een klanr over een lamellenplafond: het was niet goed. En inderdaad: er zat een golving in. Die klant vroeg 400.000 frank vergoeding en het hele plafond had ons 450.000 frank gekost. Dus we hadden praktisch voor niks gewerkt. Dat kan dan niet. De leverancier was bereid 180.000 frank korting te geven. Dat accepteerde de klant niet. Maar na onderhandelen zijn we toch tot een overeenstemming gekomen. Zo moet je proberen het op te lossen, want als je het met juridische stappen gaat proberen, dan komt er uiteindelijk ook zoiets uit de bus, alleen kost het dan ook nog een keer een hoop geld." (Genk)

Men is doorgaans niet erg happig op gerechtelijk procedures. Het meest genoemde bezwaar is dat een procedure zeer lang duurt. De schattingen van de procesduur lopen uiteen, maar men is eenstemmig in de mening dat het 'hier in Belgiè' erg lang is. Het is een kwestie van meerdere jaren. Er worden wel termijnen genoemd van 8 tot 10 jaar, voordat een zaak in verschillende gerechtelijke instanties definitief is afgedaan. En dat is een groot bezwaar in een branche waarin het bedrijfskapitaal niet zo lang in een project kan blijven steken vanwege de afwikkeling van nieuwe projecten. De betalingstermijnen voor leveranciers en onderaannemers zijn relatief ruim, maar bedragen hooguit twee maanden en zeker geen jaren. Wie niet zeer ruim bij kas zit komt aldus snel in de knel met nieuwe opdrachten.

Voorts worden procedures vermeden als het om relatief (in verhouding tot de bouwsom) om kleine bedragen gaat. Zo is Kamerlo van plan een procedure aan te spannen tegen een non-profit organisatie die een onderdeel van de afrekening betwist. Het betwiste bedrag is 12 miljoen frank:

"Het bedrag is te groot. Als het I miljoen zou zijn, dan kun je dat links of rechts wel recupereren. 12 miljoen is wat veel." (Kamerlo) 
Nog een ander motief voor het vermijden van gerechtelijke stappen is dat men met de tegenpartij een goede relatie wil behouden. Zo stelt de zegsman van Hotbeek dat in projecten het opbouwen van een relatie soms jaren in beslag neent, maar dat een slechte reputatie snel gevestigd is. Het maakt wel uit om welke klanten het gaat. Hoelbeek heeft alleen opdrachtgevers uit de industrie. Ook Kamerio geeft aan dat procederen tegen regelmatige opdrachtgevers uit de industrie dodelijk is voor de relatie: "dan lig je eruit".

Niettemin worden conflicten soms met juridische middelen aangepakt. Het gaat daarbij vooral om kwesties met onderaannemers en klanten. Het is betrekkelijk uitzonderlijk dat conflicten met een leverancier niet in der minne worden gregeld. Alleen Hoelbeek verhaalt van een geschil met een verfleverancier, dat nitt kon worden bijgelegd. De schade werd uiteindelijk door Hoelbeek zelf gedragen en de leverancier kwam op de zwarte lijst. Het betreft een leverantie van brandw:rende verven. De verf wordt op de profielen aangebracht. De leverancier kont metingen doen in de werkplaats. Hij schrijft zelfs een papier dat hij metingen heeft gedaan conform de voorschriften. Die profielen worden gemonteerd op ce werf. De bouwheer vraagt op de werf in hoeverre de gebruikte producten geschilt zijn conform de Belgische normen. De vraag wordt doorgespeeld aan de leverascier. De feverancier spreekt over Franse en Italiaanse normen. Maar Belgische normen worden gevraagd. Hij moet dan toegeven dat zijn product daar niet aan voldoet. Hij stelt dat er in België niet een echt keuringsorgaan bestaat, waardoor hij zijn producten zou kunnen laten keuren.

"Op een bepaald moment ging het over serieuze bedragen, ongeveer 5 miljoen frank, die zouden worden ingehouden door de bouwheer. Wij zaten in een moeilijke situatie waarin wij vonden dat de leverancier in de fout ging waarin we eigenlijk de bouwheer gelijk gaven. We zijn een aantal keren rond de tafel gaan zitten met de leverancier. Die heeft eigenlijk het been stijf gehouden. Het gevolg is gewest dat Hoelbeek die schade op de werf hersteld heeft en naar de leverancier toe zijn alle bruggen opgeblazen. Die staat op de zwarte lijst. Dat hoort bij ISO. Maar dat zouden we toch gedaan hebben." (Hoelbeek)

Men blijft tenslotte zitten met een schadepost van 200.000 frank. Het voorstel van de leverancier vindt men 'onterecht': Hoelbeek zou bij volgende bestellingen korting krijgen. Hoelbeek is daar niet mee akkoord gegaan.

"Van die 200.000 frank is verder geen werk gemaakt. In de eerste plaats omdat men het werk wil afmaken teneinde de opdrachtgever tevreden te stellen. Maar zodoende zou men ook het bewijsmateriaal vernietigen. En bovendien vindt men het bedrag niet groot genoeg om de advocaat en (waarschijnlijk) de rechter voor in te schakelen." (Hoelbeek)

Alle respondenten zijn wel in een of meer conflicten betrokken geraakt die via de advocaat in de afgelopen 3 jaar uitmondden in een gerechtelijke procedure. Het zijn niet steeds grote aantallen. De zegsman van Waterschei heeft in 22 jaar 5 dos- 
siers verzameld, waarvan er nog één aanhangig is. Zelfs Bilzen heeft enkele gerechtelijke procedures onder handen. Het gaat om een tweetal vorderingen tegen kandidaat opdrachtgevers in verband met aanbestedingsperikelen. Daarnaast heeft Bilzen in de afgelopen 15 jaar eenmaal geprocedeerd regen een onderaannemer.

"Hij moest afbraak en grondwerken doen. Alleen het eerste beefi hij half gedaan. We hadden een contract en daarin stipuleren we dus zoveel voor afbraak, zoveel voor grondwerken. En ook wat er zou gebeuren als hij niet op tijd klaar zou zijn. Toen hebben we een andere aannemer erin moeten zetten, maar die was duurder omdat het snel moest. Toen is die man veroordeeld geworden voor 1 miljoen frank schadevergoeding. Het is nu in beroep. Als het beroep is uitgesproken wordt er dus betaald." (Bilzen)

Sommigen hebben meer ervaring. Daarbij gaat het vooral om gerechtelijke acties tegen klanten. Bij Hoelbeek komt het één tot twee maal per jaar voor dat men een procedure start tegen een klant die "onrechtmatig veel geld inhoudt". En bij Genk gebeurt dat tenminste driemaal per jaar, vooral in verband met het uitblijven van betalingen door de klant.

Er zijn overwegingen die bij alle aarzelingen tegen gerechtelijke stappen toch de balans naar de andere kant kunnen doen omslaan, in het geval dat partijen niet tot een gezamenlijke oplossing van het geschil kunnen komen en de positie van de eisende partij er niet bij voorbaat hopeloos uitziet. Het omstreden financiële belang moet allereerst zo groot zijn dat het de extra kosten waard is. Verder dient het gevaar afwezig te zijn dat het bedrijf vaste klandizie verliest. Dat is een omstandigheid die bijvoorbeeld bij Genk een rol lijkt te spelen: het bedrijf heeft voornamelijk eenmalige opdrachtgevers uit de industrie. Doorgaans geldt: wie in deze sector procedeert tegen een klant is die klant kwijt. Volgens de zegsman van Kamerlo is dat overigens niet noodzakelijk het geval wanneer de Staat de klant is. ${ }^{17}$

Als een procedure is opgestart prefereert men soms toch nog een tussentijds compromis, bijvoorbeeld naar aanleiding van een uitgebrachte gerechtelijke expertise. Maar enkele respondenten (Bilzen, Kamerlo) geven te kennen er in voorkomende gevallen geen been in te zien de zaak lang te laten lopen. De aantrekkelijke kant daarvan is de wettelijke rente die in het verschiet ligt, die veel

17 Tegen de Staat heeft zijn bedrijf enkele (reeds zeer lang lopende) procedures over enorme geldsbedragen lopen. Zijns inziens gaat het hierbij om cen mechanisme dat vooral draait om het ontgaan van verantwoordelijkheid: [...] Intussen heeft men al drie nieuwe ministers. Als ze gaan betalen zeggen ze: daar ben ik niet verantwoordelijk voor. De Staat gaat ook systematisch in beroep. [Ze denken] "Tegen die tijd ben ik met pensioen" en "Laat anderen het tegen die tijd maar oplossen". En ook de advocaat heeft er niets op tegen. Die wordt betaald. Zo is iedereen gelukkig. (Schrijn) 
hoger is dan de marktrente. Ze zien de procedure als een interessant spaarpotje. Toen ik deze optie memoreerde tegenover de zegsman van Hoelbeek reageerde hij met de veronderstelling dat het wel zou gaan om collega's die al generaties in de bouw zitten en goed bij kas zijn: hij zou zich dat als nieuwkomer niet kunnen permitteren.

\section{Resumerend}

De conclusie voor de kunststofverwerkende industrie is vrij eenduidig. De reflexieve methoden die men daar, zoals ook in Nederland inzet, staan niet in verband met de geboden justitiele faciliteiten in de verschillende landen. Die methoden zijn daar niet op gericht. Ze beogen in de eerste plaats klanttevredenheid te bewerkstelligen. Het gaat er om klachten te voorkomen. De procedures zijn in het geheel niet aan de orde. Voor zover deze werkwijzen tot gevolg hebben dat er minder klachten tot conflicten leiden en zo tot minder procedures, is dit gevolg een onbedoeld gevolg. Voor het overige komen procedures hoogst zelden voor.

In de bouwnijverheid is de situatie anders. "In de bouw gaat altijd wat mis", wordt wel gezegd en net als in de branche van de kunststofverwerkende industrie zullen de meeste knelpunten in overleg worden opgelost. Maar, zoals is gebleken, 'discussies' komen in de bouwnijverheid vaker voor. Uit de Belgische en Duitse gegevens komen ongeveer dezelfde aspecten van de bedrijfsvoering als conflictgevoelig naar voren als in Nederland. Aan de zijde van de onderaannemers zijn er de problemen met de 'timing' van de werkzaamheden, althans in België. Aan de kant van de opdrachtgevers ontstaan er regelmatig problemen over de betaling van meerwerk en over de betaling van de resterende bouwsom bij de oplevering in verband met al dan niet vermeende gebreken. Met leveranciers van grondstoffen en concurrenten zijn er zelden conflicten.

Toch gaat ook in deze sectoren, naar men zegt, de voorkeur uit naar het schikken van geschillen buiten het gerecht om. Daarvoor worden verschillende redenen aangevoerd, maar de belangrijkste is dat het te lang duurt voordat in rechte een definitieve beslissing wordt verkregen. Interessant is dat de procesduur die wordt opgegeven, in België (rond de 8 jaar) veel langer is dan de periode die men in Duitsland noemt (rond de 3 jaar), maar dat dit verschil in feite weinig uit lijkt te maken voor de mate waarin het vermijden van gerechtelijke procedures wordt geprefereerd. Dit wordt in verband gebracht met de ondernemingslogica van de bouwnijverheid: de aannemer steekt veel geld in een project en het is zaak dat er weer zo snel mogelijk uit te halen, omdat het nodig is voor andere projecten. Het gaat bij bouwprojecten snel om veel geld, dus ook enkele lang lopende procedures 
kunnen een aannemer bankroet maken. Een procedure van 3 jaar is daarbij evenzeer te lang als een van 8 jaar. Onder dergelijke omstandigheden geeft men als her even kan de voorkeur aan een schikking, als het minste van twee kwaden. Want ook een schikking kan kostbaar en frustrerend zijn.

Een tweede punt van belang voor dit onderzoek is dat uit de Duitse gegevens naar voren komt, dat onder omstandigheden het gegeven van voor de bouwnijverheid onaantrekkelijke gerechtelijke voorzieningen ook kan leiden tot bepaalde maatregelen om conflictstof te voorkomen. Als het relatief goed gaat in de branche kan men zich wel een risico veroorloven, maar als er een recessie optreedt, zoals dat bij toeval in Duitsland het geval bleek, vergroot dat de kans op problemen. Die problemen hebben dan vooral betrekking op het slecht of niet betalen van klanten. We hebben kunnen constateren dat verschillende Duitse bedrijven onder dergelijke omstandigheden structureel overgaan tot een strikte selectie van aantrekkelijke (dat wil zeggen goed betalende) klanten. Als dit een algemeen reactiepatroon zou zijn dan zou dit kunnen betekenen dat er geen lineair verband verwacht mag worden tussen het optreden van een recessie en de toename van het aantal door ondernemers aangespannen gerechtelijke procedures. Misschien zal dat verband er aanvankelijk wel zijn, maar na verloop van tijd zullen de ondernemers hun maatregelen nemen. De aannemers zullen proberen de recessie te overleven en selectie gecombineerd met het inkrimpen van het bedrijf is in dergelijke omstandigheden een mogelijke en begrijpelijke strategie. ${ }^{18}$ Op basis van het beperkte aantal respondenten van dit onderzoek kan daarover uiteraard geen stellige uitspraken gedaan worden.

Tot slot nog een enkel woord over ISO-kwaliteitsborging. Opvallend is dat alle Belgische respondenten ISO-gecertificeerd bleken, terwijl dat in Duitsland slechts met een enkel bedrijf (het grootste) het geval was. De overige Duitse respondenten voerden voor afwezigheid van een certificaat als redenen aan, dat het door de opdrachtgevers niet werd vereist en dat het overigens te duur was. Hun Belgische collega's legden daarentegen soms uitgesproken enthousiasme aan de dag voor de mogelijkheden van een kwaliteitssysteem. Overigens waren hun motiveringen uiteenlopend, maar het bedwingen van productiekosten werd meermalen genoemd. Ik heb evenwel niet kunnen constateren dat het daaraan bij de Duitse bedrijven vanwege het ontbreken van een kwaliteitssysteem ontbrak.

18 Een interessante vraag is of dat in Nederland niet zou gebeuren bij een recessic, omdat daar de arbitrageprocedure korter is? 


\section{BIJLAGE: Profielen van Duitse en Belgische bedrijven}

\section{Kunststofverwerking Duitsland}

Form is een klein bedrijf met ruim 30 werknemers. Het maakt kunststofonderdelen van allerlei machines. Het gaat hier om enkele exemplaren of kleine series. Het bedrijf is onderdeel van een familieholding, maar is in de bedrijfsvoering geheel zelfstandig. De grondstoffen komen voor een belangrijk deel uit de chemische industrie en onder de grootste afnemers zijn enkele multinationale concerns.

Schaum is een iets groter bedrijf met 70 werknemers. Het vervaardigt kunststof verpakkingen voor voedingsmiddelen. Het is een echt productiebedrijf. Het is een zelfstandig bedrijf met een buitenlandse vestiging en verkoopbureaus in twee continenten. Ook hier grote chemieconcerns aan de leverancierszijde. De afnemers zijn vooral groothandelsbedrijven.

Thermo is ongeveer even groot als Schaum. Het vervaardigt kunststof dock met een kunststof bekleding dat voor zeer uiteenlopende doeleinden kan worden gebruikt. Ook dit is een productiebedrijf. Het is onderdeel van een groot moederconcern en levert een belangrijk deel van de omzet aan verzelfstandigde verkoopbureaus die tot hetzelfde bedrijf behoren. De grondstoffen komen grotendeels uit de chemische industrie.

Flasche is een middelgroot bedrijf met ongeveer 100 medewerkers. Het is een van de tientallen zelfstandige productiefaciliteiten (verspreid over twee continenten) van een groot concern dat gespecialiseerd is in kunststof containers met allerlei stoffen kunnen worden gevuld. De grondstoffen worden betrokken uit de chemische industrie, en de klanten zijn hoofdzakelijk grote concerns die in hoofdzaak huishoudelijke producten fabriceren.

Rein is een middelgroot bedrijf met 120 werknemers. Het is een grotendeels zelfstandige dochter van een groot Scandinavisch bedrijf. Het is gespecialiseerd in de fabricage van onderdelen van reinigingsinstallaties. Het is zowel een productieals een projectbedrijf.

\section{Kunststofverwerking België}

Plaat is een klein bedrijf met 16 werknemers. Het bedrijf verkoopt materialen voor dakbedekking. Het is onderdeel van een grote internationale groep met enkele productiebedrijven en tientallen verkoopbureaus. Men voert verschillende producten van de groep, die ook het grootste deel van de inkoop vormen. Maar als cen ander product in de omgeving goedkoper is kan dat ingekocht worden. De grotere afnemers zijn distributeurs en daarnaast zijn er tal van kleinere klanten. 
Markies is eveneens een klein bedrijf met 34 werknemers. De onderneming vervaardigt, verkoopt en installeert systemen voor zonwering. Het bedrijf is bij een buitenlandse groep aangesloten, die vestigingen in verschillende Europese landen heeft. De inkoop gebeurt voor een groot deel bij bedrijven die tot de groep behoren. Het grootste deel van de afzet gaat naar de vakhandel, een kleiner deel wordt verkocht via installatieprojecten, dat wil zeggen het verzorgen van de complete zonwering in een bepaald utiliteitsproject.

Kist is een groter bedrijf met 90 werknemers. Het bedrijf fabriceert kunststof kratten. De leveranciers zijn in hoofdzaak grote chemische bedrijven. De klanten zijn fabrikanten van allerlei dranken. Het bedrijf is een onderdeel van een groot beursgenoteerd verpakkingsbedrijf.

Buis is een middelgroot bedrijf met ongeveer 100 werknemers; alle filialen meegerekend 150. Bij Buis worden kunststof buizen gefabriceerd en verkocht (direct of via de filialen) en daarnaast worden nog hulpstukken verkocht die elders gemaakt worden. Dit bedrijf is een dochteronderneming van een buitenlandse firma, die in verschillende Europese landen vestigingen heeft. En deze groep is weer gelieerd aan een nog weer grotere (beursgenoteerde) onderneming. De leveranciers zijn grote chemieconcerns die grondstoffen leveren en zusterbedrijven of externe bedrijven die hulpstukken vervaardigen. De klanten zijn enkele grote bedrijven in de gas-, water- en electriciteitsector en daarnaast een groot aantal grotere en kleinere aannemers.

Parts is net geen groot bedrijf met 250 personeelsleden en een omzet van 80 miljoen gulden. Er worden bij dit bedrijf kunststof onderdelen voor personenauto's gemaakt. Ook hier zijn de chemieconcerns de grote toeleveranciers en beperkte groep autofabrieken de opdrachtgevers. Dit bedrijf is een dochteronderneming van een groot verpakkingsconcern.

\section{Bouwnijverheid Duitsland}

Birk is een zelfstandig klein bouwbedrijf met 20 personeelsleden. Het is vooral actief in grondwerzaamheden, waarbij veelal gemeenten de opdrachtgevers zijn. De overige bouwactiviteiten betreffen vooral de constructie van kant-en-klare fabriekshallen ('turn key' projecten). Het personeelsbestand van het bedrijf is als gevolg van de teruglopende opdrachten (vooral van gemeenten) in de afgelopen tien jaar beduidend ingekrompen.

Stolberg heeft als middelgroot bouwbedrijf 60 werknemers in dienst. De onderneming is hoofdzakelijk actief in de industriebouw, voornamelijk in opdracht van ondernemingen in de regio. Het bedrijf is zelfstandig.

Koslar is een middelgrote zelfstandige bouwonderneming met 70 personeelsleden. Het bedrijf is in beginsel actief op een breed scala van bouwactiviteiten. Maar door de slechte bouwmarkt is het aantal werknemers en het spectrum van 
werkzaamheden sterk gereduceerd. Men concentreert zich op seriematige opdrachten (zoals tankstations) en woningbouwprojecten.

Hitfeld heeft als middelgrote zelfstandige bouwonderneming ongeveer 200 mensen in dienst. Er is een dochteronderneming in de 'neue Bundesländer'. Er worden grondwerken verricht voor de spoorwegen en gemeenten. Daarnaast is men actief in de industriebouw.

Alsdorf is een grote zelfstandige bouwonderneming met ruim 300 werknemers in dienst. Ook hier is onder invloed van de slechte marktomstandigheden het aantal werknemers de afgelopen jaren beduidend ingekrompen. Er zijn nog twee nevenvestigingen, waarvan een in de nieuwe deelstaten van de Bondsrepubliek. De onderneming verricht een breed scala van bouwwerkzaamheden. Een anzienlijk deel betreft industriële 'turn key' projecten. Alleen deze firma is ISO-gecertificeerd.

\section{Bouwnijverheid België}

Bilzen is een onderneming met ruim 50 werknemers. De activiteiten zijn verdeeld over woningbouw, utiliteitsbouw, industriebouw en projectontwikkeling. Het bedrijf is na een grondige voorbereiding ISO-gecertificeerd. De bedrijfsleider is zeer 'quality minded' en gaat er prat op in 15 jaar geen gerechtelijke procedures te hebben gevoerd.

Hoelbeek is een bedrijf met 60 werknemers. Men is gespecialiseerd in industriële gebouwen die geheel afgewerkt ('turn key') worden opgeleverd. Ook dit bedrijf is zeer op kwaliteit georiënteerd. Naast een ISO-certificatie is er ook een veiligheidscertificaat en het streven is op termijn ook milieuzorg toe te voegen, zodat het kan worden samengebracht in een ISO-14000 systeem (TQM). De actieradius van de onderneming omvat naast België ook het zuiden van Nederland en een stuk van Duitsland.

Kamerlo heeft 140 werknemers in dienst. De activiteiten omvatten utiliteitsbouw, kantoorrenovatie en industriebouw. Men bouwt uitsluitend in België. Het bedrijf is ook ISO-gecertificeerd.

Waterschei is een bedrijf met 180 werknemers. Naast de woningbouw is men ook actief in de utiliteitsbouw en industriebouw. Er is wel een ISO-certificaat maar geen certificaat voor bedrijfsveiligheid. Dat laatste wordt ervaren als een gemis, omdat men daardoor opdrachten denkt mis te lopen.

Genk is een onderneming met 220 werknemers. Het bedrijf is geheel gespecialiseerd in 'turn key' projecten voor de industrie. Het gaat daarbij voornamelijk om stalen fabriekshallen en showrooms annex garages (voor motorvoertuigen). Opmerkelijk is dat deze firma één van de belangrijkste bouwelementen (stalen paneien) volledig betrekt van één leverancier. Het bedrijf is ook ISO-gecertificeerd. 


\section{HOOFDSTUK 6}

\section{Conclusies}

De vraagstelling van dit onderzoek ligt in het verlengde van de eerdere bevinding dat bedrijven die grote aantallen consumenten bedienen, werkwijzen hebben ontwikkeld - en naar verluidt met succes gebruiken - om het ontstaan van mogelijke juridische problemen (met name betalingsproblemen) te voorkomen en de desondanks ontstane problemen zo efficiënt mogelijk af te doen. De gesignaleerde methoden bleken typisch administratieve procedures, waarmee getracht wordt lering te trekken uit opgedane eigen ervaringen. De preventie van deze problemen was vooral gebaseerd op het selecteren van klanten: het uitsluiten of apart behandelen van 'slechte' klanten, en daarnaast het aantrekken van 'goede' klanten. Gerezen betalingskwesties werden afgehandeld volgens op ervaringen gebaseerde routines.

In dit onderzoek vormen dergelijke preventieve methoden (hier 'reflexieve methoden' genoemd) het eerste onderzoeksthema: worden ze ook gebruikt in relaties tussen bedrijven onderling, wat zijn de overwegingen en omstandigheden die het gebruik (of niet-gebruik) van deze reflexieve methoden begrijpelijk kunnen maken en zijn ze van invloed op het omgaan met en de frequentie van klachten en geschillen? De antwoorden op deze vragen zouden ook licht kunnen werpen op twee rechtssociologische kwesties. Het tweede onderwerp van dit onderzoek vormen de zogenaamde 'duurzame relaties' die blijkens onderzoek van Macaulay in de jaren ' 50 en ' 60 valk kenmerkend waren voor het Amerikaanse zakenleven. In de jaren ' 80 suggereerden Galanter en Rogers dat dergelijke duurzame relaties aan erosie onderhevig waren, met name onder druk van de toegenomen internationale concurrentie. Dit zou een belangrijke verklaring zijn van de gesignaleerde toename van het aantal civiele procedures tussen bedrijven. $\mathrm{Zijn}$ er aanwijzingen te signaleren voor het verdwijnen van duurzame relaties in zakenrelaties en houden de reflexieve methoden mogelijk verband met of zijn ze zelfs een reactie op de door Galanter en Rogers veronderstelde ontwikkeling? Het derde onderwerp betreft de vraag hoe bepalend de juridische infrastructuur is op het omgaan met klachten en geschillen in relaties tussen bedrijven. Hierbij is een stel- 
ling van Blankenburg als uitgangspunt genomen die inhoudt dat deze invloed zonder meer bepalend is. In hoeverre wordt het gebruik van reflexieve praktijken vooral door de kwaliteiten van de juridische infrastructuur uitgelokt (of overbodig gemaakt) en wordt de hantering van ontstane klachten en geschillen door deze structuur beïnvloed?

Voor het verkrijgen van meer inzicht in de eerste twee kwesties zijn diverse bedrijven van enkele branches in Nederland bevraagd over de manier waarop ze met mogelijke conflictstof in de relaties met toeleveranciers, klanten en concurrenten omgaan. Er zijn branches geselecteerd die sterk verschillen wat betreft de frequentie waarmee zich in de relaties met andere bedrijven fricties voordoen. Getracht is om een antwoord op de aan de these van Blankenburg ontleende vraag te traceren door de branches die in Nederland het meest blijken te verschillen wat betreft het voorkomen van klachten en geschillen, ook te bevragen in nabijgelegen regio's (in Duitsland en België) met een ander regime wat betreft de kosten en snelheid van civiele procedures.

De belangrijkste conclusies van het onderzoek met betrekking tot deze vragen komen in de volgende paragrafen eerst aan de orde. Paragraaf 1 doet verslag van de bevindingen ten aanzien van de preventie van storingen en de reflexieve methoden die de laatste jaren in het bedrijfsleven in zwang zijn gekomen. Tevens wordt kort beschreven hoe de klachten en geschillen die niettemin rijzen in de verschillende branches worden gehanteerd en welke rol het doen van juridische stappen daarbij speelt. In paragraaf 2 worden de vragen naar (a) het bestaan en de betekenis van de 'duurzame relaties' in het bedrijfsleven en (b) de effectiviteit van reflexieve methoden samengebracht als elementen van de typerende 'logica van het ondernemen' van de verschillende branches die zakenrelaties arm of juist rijk aan fricties doet zijn en van invloed zijn op de kans op het ontstaan en escaleren van geschillen. In paragraaf 3 wordt afzonderlijk stil gestaan wat er in de interviews naar voren is gekomen over de aard van en de diversiteit aan motieven voor het onderhouden van de 'longterm continuous relations' van Macaulay. In paragraaf 4 wordt ingegaan op het gewicht van de juridische infrastructuur voor het gebruik van reflexieve methoden en hun invloed op het hanteren van gerezen geschillen. De afsluitende paragraaf 5 grijpt terug op de in hoofdstuk 2 ontwikkelde perspectivistische benadering van rechtspraak en bepleit de complementariteit van onderzoek betreffende de vraag-en de aanbodzijde van rechtspraak.

Deze conclusies hebben uiteraard een beperkte reikwijdte. Er zijn slechts enkele branches in het onderzoek betrokken, het aantal ondervraagde bedrijven is klein en het gaat vooral om kleine en middelgrote ondernemingen. Het onderzoek is immers niet in de eerste plaats gericht op een representatieve beschrijving, maar op het traceren van de logica van de positie waarin ondernemers uit verschillende branches opereren. Vanuit deze logica zou het (niet)gebruik en effect van reflexieve methoden, het al dan niet onderhouden van duurzame relaties en het al 
dan niet doen van juridische stappen begrijpelijker moeten worden. Toch worden er conclusies van beschrijvende aard getrokken, die echter steeds tentatief bedoeld zijn. Dit moet bij het volgende in gedachten worden gehouden, waar met clausuleringen spaarzaamheid is betracht om de leesbaarheid te bevorderen.

\section{Preventie en hantering van klachten en geschillen}

\subsection{Preventie}

Er zijn uit de gesprekken enkele methoden naar voren gekomen die gelijkenis vertonen met de 'routinisering van de probleembehandeling' die ook al in de consumentensector was gesignaleerd. Bij een enkel bedrijf met een groot aantal kleinere klanten (het duidelijkste voorbeeld is het Belgische bedrijf 'Buis') wordt gewag gemaakt van een organisatie van de afdoening van de problemen (ook vooral incassoproblemen) die lijkt op de manier waarop bedrijven dat doen, die te maken hebben met grote aantallen particuliere consumenten.

Een meer prominente rol lijkt er echter in het verkeer tussen bedrijven onderling weggelegd voor methoden die de risico's van de problemen die men moeilijk te vermijden acht, onschadelijk kunnen maken. Risico's in de sfeer van de betaling door klanten worden beperkt door het verlangen van vooruitbetaling of voorschotten. Allerlei risico's van eigen of andermans handelen worden afgedekt door verzekeringen. Verzekeringen spelen in alle bedrijfstakken een rol, maar blijkt met name in het Nederlandse wegtransport de aangewezen manier om de risico's van het vak te beheersen. Daarnaast blijkt voor internationaal opererende bedrijven een kredietverzekering vaak aantrekkelijk. In feite is dit een reflexieve techniek waarbij een onderzoek naar de kredietwaardigheid van de klant (door de verzekeraar) een belangrijke rol speelt.

Naast deze werkwijzen zijn met name de methoden interessant, die door de bedrijven zelf worden gehanteerd om problemen met leveranciers en klanten te voorkomen. Integrale probleempreventie van storingen is in de afgelopen jaren in het bedrijfsleven snel in de mode gekomen onder de noemer: 'kwaliteitszorg'. Verschillende onderdelen daarvan zijn echter direct herkenbaar als meer traditionele methoden om de kans op problemen met relaties te beperken.

\section{A) Traditionele methoden}

\section{De selectie van 'goede relaties'.}

Opmerkelijk is dat een aanmerkelijk deel van de inkoop en verkoop bij met name de kunststofverwerkers en de wegtransporteurs zich voltrekt tussen het bedrijf en 
een beperkt aantal klanten (en bij de kunststofverwerkers ook leveranciers) waarmee doorlopende betrekkingen worden onderhouden. Uiteraard is het onderhouden van vaste relaties niet altijd mogelijk, zoals met opdrachtgevers in de bouwnijverheid. Maar de indruk is ontstaan dat er in de zakelijke transacties met andere bedrijven een sterke voorkeur bestaat voor het aanknopen van duurzame relaties voor tenminste een deel van deze transacties. Dergelijke relaties bestaan er in verschillende modaliteiten, die allemaal - ook op verschillende manieren - van invloed zijn op de frequentie waarmee zich klachten voordoen.

Een belangrijke motief voor het aanknopen van vaste relaties met klanten en leveranciers is doorgaans, dat men zich zo op grond van eigen ervaring zekerheid verschaft over hun betrouwbaarheid wat betreft kredietwaardigheid en de capaciteit om te presteren wat verlangd wordt. Het risico van onbetrouwbaarheid is soms niet helemaal uit te sluiten, bijvoorbeeld wanneer er weinig alternatieven zijn of wanneer zich een op het eerste gezicht aantrekkelijk kandidaat-relatie aandient. In het eerste geval wordt getracht, zoals bijvoorbeeld met bepaalde onderaannemers in de bouw, het gewenste gedrag aantrekkelijk te maken. In het laatste geval wordt er over de aspiranten informatie ingewonnen, veelal bij gespecialiseerde instanties (bedrijven die 'handelsinformatie' verkopen) en vaak ook tegelijkertijd in de informele circuits, bijvoorbeeld bij collega's van de mensen in het veld. Daarna wordt de nieuwe klant of toeleverancier eerst uitgeprobeerd voor men zich verder op hem verlaat. Bij voorkeur gaat men af op eigen ervaringen. Waar duurzame relaties structureel niet goed mogelijk zijn, zoals aan de kant van de opdrachtgevers in enkele sectoren van de bouwnijverheid, zal de kans op problemen en geschillen en het escaleren ervan, navenant groter zijn.

Aan zakenrelaties worden echter vaak meer eisen gesteld dan aan relaties met consumenten. Uit de gevoerde gesprekken komt meermalen een voorstelling van de 'goede' zakenrelatie naar voren die meer omvat dan alleen het strikt nakomen van de afspraken. Een goede relatie noemt men wel een 'partner' en de benaming geeft aan dat men over en weer (daadwerkelijk) bereid is meer te doen dan is overeengekomen of zelfs dingen te doen waartoe strikt genomen geen enkele verplichting bestaat. Eén en ander lijkt hoofdzakelijk gebaseerd op het besef van wederzijdse afhankelijkheid, in voorspoed maar vooral ook in tegenspoed. Als dit type economische binding werkt zoals het bedoeld is, kunnen problemen voorkomen worden en onvermijdelijke problemen opgevangen en onschadelijk gemaakt worden. Voorts kunnen dergelijke relaties onmisbaar zijn om onvoorzienbare tegenslagen te overwinnen. Aan het verwerven en behouden van dergelijke relaties wordt derhalve belang gehecht. Op de regels die bij dergelijke verhoudingen opgeld doen, wordt in paragraaf 3 nader ingegaan. 


\section{Schriftelijk contract.}

Een andere methode om problemen en geschillen te voorkomen, die meermalen door bedrijven uit verschillende branches wordt genoemd (zowel in verband met leveranciers als met klanten) duidt men wel aan als 'het maken van duidelijke afspraken' of 'communicatie'. Wat dat precies betekent en de vorm waarin dat gegoten wordt kan per branche verschillen, maar het komt er meestal op neer dat zo groot mogelijke duidelijkheid dient te bestaan over essentiële zaken, zoals de specificaties van het product, de prijs, tijdstip, plaats en methode van levering en tijdstip en wijze van betaling. En er wordt dan meestal bijgezegd dat de op deze punten gemaakte afspraken bij voorkeur ook op papier moeten worden vastgelegd. Er bestaat op dit vlak blijkbaar weinig behoefte aan informaliteit.'

Bijvoorbeeld in de kunststofverwerkende industrie wordt veel nadruk gelegd op expliciete specificaties van het product, zowel in relatie tot de leverancier als tot de klant. Die specificaties zijn vaak gestandaardiseerd (bijvoorbeeld internationaal gehanteerde technische 'productnormen' voor chemische grondstoffen), maar soms ook in samenwerking (bijvoorbeeld speciale halffabrikaten, onderdelen en eindproducten) ontwikkeld. In beide gevallen laten de afgesproken specificaties weinig ruimte voor discussie als er problemen rijzen over de kwaliteit van het product. Deze duidelijkheid wordt overigens niet alleen van belang geacht tegenover de leverancier of klant. Ook voor de verschillende afdelingen binnen de eigen organisatie die bij de uitvoering van de order betrokken zijn, wordt zo'n document gewaardeerd als methode om problemen over belangrijke aspecten van het product te voorkomen.

In de bouwnijverheid liggen de zaken gecompliceerder. Ook daar zijn er voorstanders gesignaleerd van het zorgvuldig schriftelijk specificeren van bestellingen bij leveranciers en opdrachten aan onderaannemers; en bovenal van bestekken van opdrachtgevers. Maar met name in de twee laatste gevallen gaat het nogal eens mis met het maken van 'duidelijke afspraken'. Wat de onderaannemers betreft wordt dit vooral geweten aan hun geringere administratieve capaciteiten en daarnaast aan de onzekere economische positie waarin met name de kleinere bedrijven verkeren; zij voelen zich soms genoodzaakt te veel opdrachten aan te nemen uit angst voor een gebrek aan opdrachten. Dit laatste punt is interessant, omdat het aangeeft dat de onderaannemers er ook bij gebaat kunnen zijn op sommige punten niet al te duidelijke afspraken te maken. Iets dergelijks doet zich blijkbaar ook voor in de relatie tussen aannemer en opdrachtgever bij het maken

1 Tot dezelfde bevinding komen Deakin en Wilkinson, 1997: p. 123: "Numerous respondents saw contract formality as an essential aspect of doing business." 
van afspraken over de bestekspecificaties en 'meerwerk'. Daarover meer in paragraaf 1.2 .

\section{Controles}

Met name in de kunststofverwerking heeft men, waar het mogelijk en betaalbaar is, het productieproces ingebed in controles op storingen. Het is wel duidelijk, dat er daarover kosten/baten afwegingen worden gemaakt. Het (al dan niet zelf) testen van aangeleverde grondstoffen wordt soms nagelaten omdat de leveranciers naar de ervaring leert - weinig steken laten vallen en eventuele gebreken in de leveringen (en dus ook de verantwoordelijkheid daarvoor) objectief vast te stellen zijn. Het eigen productieproces (waar de eigen verantwoordelijkheid begint) is vaak voorzien van verschillende controlemomenten, zodat storingen kunnen worden achterhaald, hun bron kan worden getraceerd en voor de toekomst kan worden geëlimineerd. Dit zijn typisch de reflexieve methoden die hierna aan de orde komen.

Maar ook in de andere bedrijfstakken wordt met controles gewerkt. In het wegtransport wordt soms gebruik gemaakt van g.p.s. om na te gaan of de voortgang van de rit zich conform de planning voltrekt. En er is onderweg meestal communicatie mogelijk tussen de chauffeur en de thuisbasis over bijvoorbeeld verkeerssituaties en weersomstandigheden. Ook in de bouwnijverheid vinden er op allerlei momenten controles plaats, bijvoorbeeld naar het voldoen van de aangeleverde materialen aan de afgesproken specificaties, het tijdig op het werk verschijnen van onderaannemers, de kwaliteit van het geleverde werk en de conformiteit aan het bestek.

\section{Beveiliging}

De concurrenten hadden een weinig prominente rol in het relatiepatroon van de bedrijven: "Nee, daar had men weinig mee te maken." Maar dergelijke opmerkingen lijken met een korreltje zout te moeten worden genomen, gezien het feit dat er bij sommige bedrijven (vooral in de kunststofbranche) een buitengewoon indrukwekkend veiligheidssysteem operationeel was en alle verzoeken mijnerzijds om een blik te mogen werpen op het productieproces vriendelijk doch beslist werden afgewezen.

\section{B) Reflexieve methoden}

De bovengenoemde werkwijzen maken tegenwoordig vaak deel uit van een omvattend systeem van 'kwaliteitszorg'. Meestal wordt er gebruik gemaakt van de internationaal gebruikte standaard voor kwaliteitsborging van de ISO-9000 serie. Maar er bestaan ook kwaliteitssystemen van individuele opdrachtgevers. 


\section{Kwaliteitszorg volgens de ISO-standaarden.}

Het blijkt te gaan om een internationaal gehanteerde methodiek om het hele productieproces zodanig te 'monitoren' en bij te sturen dat de klanttevredenheid wordt gehandhaafd en zo mogelijk vergroot. Rond alle denkbare onderdelen van het productieproces worden daartoe procedures geïnstalleerd, die het mogelijk maken 'afwijkingen en gebreken' te registreren en niet alleen op te lossen, maar ook op hun oorzaak te onderzoeken en zo mogelijk in de toekomst te voorkomen. Het gaat om een hele serie elementen van het productieproces, zoals contractevaluatie, documentenbeheer, controle en evaluatie van de producten die van de vaste toeleveranciers zijn gekocht, monitoren van het productieproces, inspectie en testen van producten, controle van afwijkende producten, ontwerp en onderhoud van methoden om afwijkingen te corrigeren en te voorkomen, opslag, verpakking en aflevering en nog veel meer. De algemene standaard is 'leeg', volledig abstract, en moet voor (en door) elk bedrijf worden 'ingevuld'. Het is de bedoeling in eerste instantie wat al aan kwaliteitszorg wordt gedaan expliciet te maken (in een kwaliteitshandboek) en vast te houden, te 'borgen'. Vanaf dat punt is het de bedoeling in een volgend stadium stappen vooruit te maken, bijvoorbeeld in de richting van 'total quality management'. Wanneer de vertaalslag van het kwaliteitshandboek is volbracht en het personeel is geïnstrueerd en gemotiveerd, kan het ISO-certificaat worden aangevraagd bij een certificerende instantie. $\mathrm{Na}$ het verlenen van het certificaat zal het bedrijf regelmatig geïnspecteerd worden door de certificerende instantie (de zogenaamde 'audit'), om te verzekeren dat het certificaat nog steeds wordt verdiend. Deze hele operatie staat in het teken van 'klanttevredenheid'. Met 'kwaliteit' wordt in dit verband meestal bedoeld: het leveren van een product met constante kenmerken, overeenkomstig de wensen van de klant. Het koningschap van de klant wordt zodoende geïnstitutionaliseerd.

Deze werkwijze voldoet geheel aan wat Giddens verstaat onder 'reflexiviteit' bij organisaties: het verzamelen van gegevens met betrekking tot het eigen functioneren in relatie met relevante elementen uit de organisatiecontext, teneinde middels analyse van die gegevens de organisatie bij te kunnen sturen of zonodig te reorganiseren, ter verbetering van de prestaties. Bij kwaliteitszorg neemt het de vorm aan van een systematisch registratiesysteem van klachten over afwijkingen en gebreken van toegeleverde, verwerkte en afgeleverde producten - klachten van leveranciers of klanten jegens het bedrijf of omgekeerd of zelfs tussen afdelingen binnen het bedrijf - waardoor de gegevens worden gegenereerd waarmee het productieproces kan worden bijgestuurd.

Op het eerste gezicht is het verbazingwekkend, dat bedrijven zich - nota bene in een tijd die in het teken staat van 'deregulering' - vrijwillig onderwerpen aan dergelijke regelregimes, die veel tijd en energie vergen en bovendien zeer kostbaar zijn. De vraag naar het waarom van het adopteren van deze werkwijze komt in paragrafen 2 en 3.5 aan de orde. 


\section{Kwaliteitssystemen van opdrachtgevers}

Blijkens sommige gesprekken bestaan er ook volledig particuliere systemen van kwaliteitszorg bij grote internationale concerns, die deze systemen zelf hebben ontworpen en uitsluitend gebruiken voor hun eigen 'relaties'. Dergelijke bedijven beschikken doorgaans over een enorm netwerk van vaste toeleveringsbedijven, die halffabrikaten of onderdelen leveren voor het product dat zij op de makt brengen. Voorbeelden zijn te vinden bij de fabrikanten van computers, auto'sen voedingsmiddelen. De toeleveranciers die tot een dergelijk netwerk willen toeteden, dienen eerst het kwaliteitscertificaat van de opdrachtgever te verwerven. Pit certificaat geeft aan, dat men in staat is overeenkomstig de kwaliteitseisen van de opdrachtgever te leveren. Naar verluidt zijn de eisen die binnen deze kwaliteissystemen gelden buitengewoon stringent. Een voorbeeld van een dergelijke st:-ndaard wordt gememoreerd door een toeleverancier van de automobielindustrie: de foutenmarge voor de onderdelen, die door hem in opdracht van de autofabrikanten worden gefabriceerd en geleverd, bedraagt soms vijthonderd, in andite gevallen slechts vijftig "parts per million". Dit kwaliteitssysteem fungeert in fete als selectiedrempel. Hier is het geen raadsel waarom het bedrijf zich deze hele operatie op de hals haalt: zonder certificaat (en de daarbii behorende prestaties) gen klant.

\subsection{Omgaan met klachten over storingen}

Tussen de verschillende branches tekenen zich verschillen af wat betreft de frequentie waarmee zich storingen aandienen en ook wat betreft de manier waarop ze worden behandeld.

Kunststofverwerking. In deze branche valt vooral te beluisteren dat ernstige storingen zeer zelden voorkomen. Met name in de relatie met de leveranciers van grondstoffen en ook in die met klanten gaat betrekkelijk zelden iets echt mis. Er treden wel storingen op, maar veel van dergelijke storingen zijn 'normale' storingen die volgens een vaste routine of zo nodig in overleg worden afgedaan. Wel wordt voor een storing altijd een klacht ingediend ten behoeve van de toepasselijke kwaliteitsprocedure.

Een problematische storing is vooral een storing die de continuïteit van de eigen productie of die van de klant in gevaar brengt. Het stilvallen van het productieproces kan schadelijk zijn voor de machines, leiden tot tijdverspilling of (het meest rampzalige) de tijdige levering aan de klant (of van de klant aan zijn afnemers) in gevaar brengen. In dat geval is een eerste vereiste: de betrokkenen zo snel mogelijk op de hoogte stellen van het dreigende gevaar, zodat ze nog in staat zijn noodmaatregelen te treffen. Wie dat nalaat en pas waarschuwt als het te laat is om nog iets te redden, gedraagt zich niet zoals het een goed 'partner' betaamt en 
brengt zijn positie in gevaar. Als de storing nog te verhelpen is, wordt verwacht dat degene die voor de prestatie verantwoordelijk is alles in het werk zal stellen om dat ook te doen. De kosten van dergelijke operaties en de schuldvraag zijn van minder en vooral van later zorg. Als schade onherstelbaar is, wordt over de vergoeding overlegd. Opmerkelijk daarbij is dat wanneer duidelijk is door wiens toedoen de schade is ontstaan, het veelal niet de gedupeerde is die een claim op tafel legt. Verwacht wordt dat de verantwoordelijke met een bevredigend voorstel komt.

Wegtransport. De frequentie van storingen lijkt groter dan in de kunststofverwerking. Het gaat dan vooral om storingen in de relatie met klanten, want in deze bedrijfstak heeft men niet veel te maken met leveranciers. Ook hier staat voorop dat de productie van de klant niet in gevaar mag komen. Met moderne communicatiemiddelen zijn vertragingen tijdig te signaleren en aan de klant te melden. De belangrijkste risico's zijn met verzekeringen afgedekt en claims worden doorgeschoven naar de vaste verzekeringsagent.

Bouwnijverheid. Storingen treden in deze branche frequent op. In de relaties met de leveranciers van grondstoffen ontstaan regelmatig, doorgaans onproblematische, storingen die volgens vaste routines worden opgelost. Problematisch is een storing vooral, wanneer daardoor een vertraging in het bouwwerk optreedt. Elke vertraging kan desastreus doorwerken in de rest van het project. Wanneer een dergelijk gevaar dreigt en de leverancier biedt niet direct een oplossing, dan wordt een alternatief gezocht en daarna worden de meerkosten bij de leverancier in rekening gebracht.

De onderaannemers kunnen (vooral in Nederland) een belangrijke bron van problematische storingen zijn, met name wat betreft het stipt nakomen van afspraken. Opmerkelijk is dat de onderaannemers, op het eerste gezicht de zwakkere partij in deze relatie, soms een behoorlijke onderhandelingspositie blijken te hebben. De aannemers zijn van hun prestaties afhankelijk, omdat zij vanwege de kosten er niet zelf toe willen overgaan allerlei vaklieden in vaste dienst te nemen en voorts omdat bepaalde vaklieden soms schaars zijn. Derhalve trachten de aannemers, naar zij zelf zeggen, vooral met geld en goede woorden de onderaannemers in het gareel te krijgen, blijkbaar niet altijd met succes.

Over het algemeen zijn storingen die vertragingen opleveren problematisch. Alleen voor de interventies van de kant van de opdrachtgever ligt dat minder duidelijk. Een project kan geheel volgens het bestek worden afgerond. Maar de opdrachtgever kan tijdens de bouw aanwijzingen geven om meer of minder te doen dan in het bestek is vastgelegd. Dat is de wereld van het meer- en minder werk. Dit is een belangrijke bron van geschillen tussen aannemer en opdrachtgever. Rond meerwerk kan gemakkelijk onenigheid ontstaan, als niet glashelder wordt 
afgesproken en vastgelegd (a) of eraan verbonden kosten al dan niet extra kosten (boven op de oorspronkelijke bouwkosten) zijn en (b) welke gevolgen ze voor de planning mogen hebben. Aan die duidelijkheid ontbreekt het echter vaak en daardoor ontstaan bij de oplevering regelmatig problemen. Voor het ontbreken van duidelijkheid over het meerwerk zijn allerlei praktische oorzaken aanwijsbaar, maar soms liet men doorschemeren dat het de aannemer soms niet onwelgevallig is. De achtergrond daarvan is dat de marge op meerwerk meestal groter is dan die op de oorspronkelijke bouwsom, een omstandigheid die aan de betekenis van de term 'meerwerk' nog een andere dimensie toevoegt. De onenigheid met de opdrachtgever wordt dan op de koop toegenomen.

\subsection{Geschillen en juridische stappen}

Over het algemeen werd me te verstaan gegeven dat ik voor conflicten en juridische problemen aan het verkeerde adres was: dat kwam zelden voor. Maar hoc zit het nu als er onverhoopt toch een conflict ontstaat: hoe kijkt men dan tegen de optie van juridische stappen aan?

Dat ligt in Nederland niet in alle branches hetzelfde. In de kunststofverwerking valt een sterke voorkeur te beluisteren voor de gezamenlijke oplossing van een verschil van mening. Er wordt op vertrouwd dat het mogelijk is er 'samen uit te komen'. Ervaringen sterken dit vertrouwen en lijken een soort conventie te schragen. Over technische kwesties kan zonodig een onderzoek van een onafhankelijk laboratorium de doorslag geven. Er wordt wel gewag gemaakt van kosten/baten afwegingen ten aanzien van procederen, maar die zijn zeer globaal en vaag. Bovendien zijn ze meestal niet gebaseerd op een ruime ervaring, want er wordt naar verluidt in deze branche weinig geprocedeerd. Het komt een enkele keer voor als het absoluut niet anders kan, bijvoorbeeld in verband met een faillissement of een inbreuk op patentrecht. Ook de transportbedrijven zijn zuinig op hun belangrijke relaties. Maar in het wegtransport zijn zoals gezegd problematische storingen en de daaruit voortvloeiende claims moeilijker te voorkomen. Dergelijke claims worden veelal voor afhandeling doorgeschoven naar de verzekeringsmaatschappij waarbij het risico is ondergebracht of naar de rechtsbijstandverzekeraar. Daar worden dan de afwegingen en beslissingen ten aanzien van te nemen stappen genomen. De bouwbedrijven lijken ten aanzien van het doen van juridische stappen, met name in de relaties met opdrachtgevers, minder terughoudend te zijn dan bijvoorbeeld de kunststofverwerkende bedrijven. De vrees voor het verlies van een vaste klant is hier duidelijk minder overheersend. Uiteraard worden ook hier kosten/baten afwegingen gemaakt, maar die klinken preciezer. Eerst worden de advocaten aan het werk gezet en als die er niet uitkomen is in Nederland de gang naar Raad van Arbitrage voor de Bouwbedrijven de gebruikelijke stap. Over de daaraan verbonden kosten en de tijd die een uitspraak 
kan vergen is men adequaat geïnformeerd. Deze factoren worden afgewogen tegen hetgeen op het spel staat. Het gaat in de bouw bij geschillen al snel om grote bedragen en dit geld heeft men nodig voor nieuwe activiteiten. Hoe krapper het bedrijf zit, des te minder is het in staat op een uitspraak te wachten. Bovendien loopt arbitrage nogal eens uit op een 'gelijk spel'. Dat alles draagt ertoe bij dat er een redelijke bereidheid bestaat samen tot een oplossing te komen, ook nog wanneer de zaak al in behandeling is bij de Raad van Arbitrage.

\section{De logica van het ondernemen}

De patronen van het omgaan met klachten en geschillen in de relatie met leveranciers en klanten verschillen per branche en ook hun effectiviteit is niet hetzelfde. Deze verschillen houden verband met een min of meer samenhangend complex van omstandigheden, waarmee ondernemers hebben te rekenen. Voor elke branche zijn die omstandigheden weer iets anders. Maar niet iedere ondernemer verkeert op dit punt in dezelfde situatic. De belangrijkste elementen van dit complex kunnen voor de drie branches als volgt getypeerd worden.

Kunststofverwerking. Het bedrijf doet zaken met grote internationale bedrijven, tenminste aan de leverancierskant en vaak ook aan de klantenzijde. Voor deze internationale bedrijven is het in de West-Europese regio 'normaal' om, zowel voor zichzelf als voor hun relaties, zeer weinig storingen te tolereren in hun transacties. Het hebben van een ISO-certificaat is in deze context dan ook niet bijzonder. De meeste ondernemingen in het onderzoek uit deze branche hadden enige vorm van kwaliteitszorg. Er was in dit opzicht geen merkbaar verschil tussen de drie landen van vestiging.

Een bedrijf dat niet voor de grote internationale concerns werkt, heeft (ofschoon ook kleinere opdrachtgevers veeleisend kunnen zijn) in dit opzicht nog enigszins een keuze. Een bedrijf dat wel voor de internationale opdrachtgevers werkt heeft die in feite niet. Een dergelijk bedrijf wordt pas als toeleverancier geaccepteerd, wanneer gebleken is dat het aan de gestelde prestatic-eisen kan voldoen. Het krijgt dan een kwaliteitscertificaat van het de klant zelf en het is ook de klant die op gezette tijden de 'auditors' langs stuurt voor controle. Het verwerven van het certificaat is het minste wat het bedrijf moet doen om de klant te behouden. Overigens gaat het bedrijf niet merkbaar onder een dergelijk regiem gebukt, integendeel: het is een onderdeel van de identiteit van het bedrijf; men is er trots op de 'grote merken' als klant te hebben. Voorts wordt er in deze sector veel met vaste opdrachtgevers gewerkt. Het verlies van een grote vaste klant kan het bedrijf voor ernstige problemen plaatsen. Meestal is het bedrijf in de loop der tijd in- 
gesteld geraakt op een bepaald type product en is het organisatorisch (onder meer door de gemeenschappelijke ontwikkeling van producten en administratieve ultomatisering) verweven geraakt met bepaalde opdrachtgevers. De lijst met vergelijkbare en beschikbare alternatieven is soms ook zeer kort. De bereidheid om de klant tevreden te houden (ongeveer de definitie van kwaliteit) is derhalve aanzienlijk. Een storingsarme prestatie is een wezenlijke opgave.

Tenslotte zijn de technische mogelijkheden om storingen te voorkomen in deze sector zeer groot. Belangrijk daarbij is dat het (veelal continue) producieproces vrijwel volledig beheersbaar is en dat het doorgaans massaproductie betreft. Het eerste brengt mee dat er weinig ruimte is voor onvoorspelbare en onbeheersbare factoren om storingen te veroorzaken. Dat is een belangrijk verschil met de andere twee branches. Het tweede technologische kenmerk markt het mogelijk om aan de hand van ervaringen, het optreden van storingen steeds verder uit te bannen.

Wegtransport. Ook in deze branche, vooral waar het om internationaal wegvervoer gaat, wordt veel gewerkt voor grote opdrachtgevers. Deze klanten zorgen voor cen bestendige stroom opdrachten voor het bedrijf en an hun wensen zal men dan ook trachten tegemoet te komen. Het overgaan tot kwaliteitszorg gebeurt soms onder pressie van een grote opdrachtgever, soms doet het bedrijf zelf de stap met het oog op het aantrekken van interessante klanten. De technische mogelijkheden om storingen te voorkomen zijn niet zo groot als in de kunststofverwerking, maar groter dan in de bouwnijverheid. Ook hier gaat het voor een belangrijk deel om het leveren van identieke diensten, met de daarbij behorende mogelijkheid om van fouten te leren. Maar sommige omstandigheden waaronder de diensten verricht worden, zijn moeilijk voorspelbaar en onbeheersbaar. Weersomstandigheden en verkeersopstoppingen kunnen in elke planning, hoe zorgvuldig ook, vertragingen doen ontstaan. En zelfs de meest ervaren chauffeur is wel eens betrokken bij een aanrijding.

Boutunijverheid. In deze branche, althans waar het om institutionele opdrachtgevers gaat, komen permanente relaties met opdrachtgevers veel minder voor dan in de andere twee bedrijfstakken. Dat vindt zijn oorzaak vooral in de omstandigheid dat er in deze sector geen massaproductie wordt geleverd, maar unieke projecten, vaak ook voor telkens andere opdrachtgevers. Hier ontstaan derhalve ook niet zo gemakkelijk de sterke bindingen met opdrachtgevers, zoals die in de andere branches zijn gesignaleerd. Aan hun wensen ten aanzien van de bedrijfsvoering zal minder gewicht worden gehecht naarmate de kans op een vervolgopdracht kleiner is. Het is hier vooral het bedrijf zelf dat om enige reden tot kwaliteitszorg besluit. In dit opzicht vertonen de bouwondernemingen uit de drie landen een verschillend patroon. In Belgiè waren de bedrijven veelal ISO-gecertificeerd, in 
Duitsland beduidend minder. De Nederlandse bedrijven namen een tussenpositie in.

Voorts zijn belangrijke omstandigheden waaronder de productie plaatsvindt door het bedrijf moeilijk voorspelbaar en onbeheersbaar. Weersomstandigheden kunnen niet alleen de voortgang van een project blokkeren, maar ook het project zelf aanzienlijke schade toebrengen. Bovendien kan elke vertraging enorme gevolgen hebben voor de planning van alle partijen die bij het bouwproject zijn betrokken. Daardoor is het uitsluiten van storingen in deze sector een moeilijke opgave. Het meeste perspectief in dat opzicht bieden de relaties, die vaak wel een min of meer bestendig karakter hebben, namelijk die met de leveranciers van grondstoffen. Veel moeilijker blijkt dat te zijn in de relatie met de onderaannemers. Ofschoon er met deze bedrijfjes vaak vaste relaties bestaan, zijn ze soms desondanks een belangrijke bron van storingen.

Samenvattend: het zijn vooral de kenmerken van de relaties met de klanten die in belangrijke mate bepalend zijn voor het hanteren en het effect van reflexieve methoden. De grootte van de partner(s), (in verband daarmee) de mate waarmee het bedrijf daarin een afhankelijke positie inneemt, de mate van duurzaamheid van de relatie(s) en de in de kring van klanten heersende omgangsvormen zijn daarbij belangrijke elementen. Daarachter is wel duidelijk de invloed van productictechnische factoren te ontwaren op de mogelijkheden om vaste relaties aan te gaan en vooral ook om storingen te voorkomen. Dezelfde inspanning om storingen te voorkomen zal daardoor in de verschillende branches niet hetzelfde effect sorteren. Het gaat hier meestal niet om los van elkaar staande relationele en technologische 'factoren'. De grote opdrachtgevers (zoals die in de kunststofverwerking en het wegtransport) zijn doorgaans op de hoogte van wat er technisch mogelijk is en zien er op toe dat hun toeleveranciers die mogelijkheden ook daadwerkelijk benutten.

Minder duidelijk kwam de invloed van institutionele factoren, zoals uniforme contractsvoorwaarden, naar voren. Ongetwijfeld zijn dergelijke condities van belang bij het neutraliseren van wat anders aanleiding tot klachten en geschillen zou kunnen geven, maar in de interviews kwamen ze weinig naar voren. Reden daarvan kan zijn dat de geïnterviewden in deze elementen niet hun eigen toedoen zien, ze beschouwen ze als 'gegeven omstandigheden'. En dan is er tenslotte de vraag wat er te bespeuren valt van de invloed van de 'juridische infrastructuur' op de inspanningen die worden gedaan om klachten over storingen te voorkomen. 


\section{Aspecten van economische bindingen}

Niet alleen in rechtssociologische kring geldt het artikel van Macaulay uit 1963 als een belangrijk erfstuk. Dat is ook het geval in de kring van economisch sociologen. ${ }^{2}$ Met name de overtuigende aanwijzingen die hij vond voor het duurzame karakter van veel zakenrelaties en de verschillende repercussies daarvan, staan daarbij op de voorgrond. ${ }^{3}$ Het is eigenlijk opmerkelijk dat een dergelijk inzicht in de sociologie - waar toch vaak sociale bindingen centraal heten te staan - als cen eye-opener wordt ervaren. ${ }^{4}$ Dat zegt waarschijnlijk iets over de greep van de economische wetenschap op ons beeld van de werkelijkheid.

Des te meer reden om te benadrukken welke diversiteit van zakelijke motieven met het onderhouden van duurzame relaties gemoeid kan zijn. In het onderzoeksmateriaal zijn aanwijzingen aangetroffen voor verschillende van deze drijfveren.

\subsection{Betrouwbaarheid.}

De vraag wat marktpartijen weerhoudt van opportunistisch gedrag, wat ze contractuele verplichtingen doet nakomen, is door economen, volgens de lezing van Granovetter, in de loop der tijd op verschillende manieren beantwoord. ${ }^{5}$ Het traditionele antwoord is dat volledige mededinging op de markt voor de nodige discipline zal zorgen: opportunisten gaan ten onder omdat er genoeg anderen zijn, die wel zaken willen doen op de voorwaarden die de markt dicteert. Eigenbelang reduceert de kans op bedrog. Maar wanneer - zoals in praktijk van het economisch leven menigmaal het geval is, bijvoorbeeld omdat niet iedereen over alles geïnformeerd is - niet voldaan wordt aan de voorwaarde van volledige mededinging, kan dit mechanisme niet functioneren en moet men een beroep doen op andere mechanismen die de nodige discipline garanderen. Van economische zijde zijn twee oplossingen voor dit probleem geopperd. In de eerste plaats hebben de aanhangers van 'institutional economics' de oplossing gezocht in de stelling dat de disciplinerende functie is overgenomen door specifieke sociale instituten, zoals in rechte afdwingbare contracten (externe dwang) of hiërarchie (interne dwang). Een andere groep economen heeft de oplossing gezocht in de werking van ver-

2 Het werd bijvoorbeeld opgenomen in een programmatische reader van de "New Economic Sociology' beweging; Granovetter en Swedberg (1992) The sociology of economic life.

3 Bijvoorbeeld in Dore (1983) Goodwill and the spirit of market capitalism en Granovetter (1985) Econemic action and secial structure.

4 Zie bijvootbeeld Wilterdink \& Van Heerikhuizen (red.)(1999) Samenlevingen.

5 Granovetter, t.a.p. 
trouwen, bijvoorbeeld gebaseerd op 'generalised morality', algemene fatsoensnormen die belangrijk zijn voor het voortbestaan van de samenleving. Deze functionalistische benaderingen worden door Granovetter afgewezen als 'undersocialized' respectievelijk 'oversocialized' opvattingen van menselijk handelen:

"Actors do not behave or decide as atoms outside a social context, nor do they adhere slavishly to a script written for them by the particular intersection of social categories that they happen to occupy. Their attempts at purposive action are instead embedded in concrete, ongoing systems of social relations." ${ }^{6}$

Het sociologisch alternatief benadrukt, onder verwijzing naar het werk van Macaulay, het belang van (netwerken van) persoonlijke relaties voor het genereren van vertrouwen en het tegengaan van bedrog. De wijdverbreide voorkeur voor het doen van zaken met partijen die - liefst op grond van eigen ervaring - als betrouwbaar te boek staan ('relaties') wijst er volgens deze opvatting op, dat weinigen genoegen nemen met algemene fatsoensnormen of institutionele voorzieningen als waarborg tegen moeilijkheden.

In het voorgaande is al aangegeven via welke selectiemethoden nieuwe relaties worden aangeknoopt. Wanneer deze status is verworven dient wel regelmatig te blijken dat men het gegeven vertrouwen waard is. Vertrouwen moet voortdurend bevestigd worden in de stroom van transacties. Wat er in sommige van de relaties die onder een kwaliteitsregime staan anders is dan bij de verhoudingen die Macaulay heeft beschreven, is wat men zou kunnen noemen de 'bureaucratisering van vertrouwen'. Daarmee wordt gedoeld op het verschijnsel van de periodieke wederzijdse evaluaties op basis van rapportages, die zijn vervaardigd aan de hand van systematisch verzamelde gegevens ten aanzien van de prestaties van de partner. Daarbij gaat men niet meer af op persoonlijke indrukken, maar baseert men zich op gegevens die als objectief worden beschouwd. Het is moeilijk voorstelbaar dat commerciële overwegingen daarbij geen rol blijven spelen en derhalve zal hier niet snel de administratieve routine de overhand krijgen. Maar het element van de persoonlijke vertrouwensrelaties kan door deze ontwikkelingen meer naar de achtergrond worden gedrongen.

\subsection{Stabiliteit}

Er kunnen meer voordelen aan duurzame relaties verbonden zijn. Met name de kleinere aannemers en onderaannemers zijn illustratief voor wat de gevolgen kunnen zijn als het aanknopen van vaste relaties met klanten structureel zo goed als onmogelijk is, wanneer het product telkens een uniek project is en de opdrachtge- 
vers ook niet kunnen zorgen voor een aanhoudende stroom van opdrachten. Dan komt de hele bedrijfsvoering op verschillende fronten in het teken te staan van instabiliteit. Want als de opdrachten op zich laten wachten, moet toch het personeel doorbetaald worden of anders ontslagen. In een dergelijke situatie ontstaat het gevaar dat goede krachten dat niet afwachten en vertrekken. En dat kan weer negatieve gevolgen hebben voor de kwaliteit van toekomstige projecten. Om het personeel aan het werk te houden zal de aannemer trachten zoveel mogelijk opdrachten binnen te halen. Dit kan ten koste gaan van zijn marge, wat de financiële positie van het bedrijf niet ten goede zal komen en het bedrijf kwetsbaar kan maken voor tegenslag. Bovendien ontstaat er een gerede kans dat hij meer werk aanneemt dan hij aankan en niet in staat is het werk op tijd of in de gewenste staat op te leveren. Als de boze opdrachtgevers dan tegenmaatregelen treffen in de sfeer van de afrekening, kunnen er weer problemen ontstaan met de toeleveranciers en de onderaannemers die nog op hun geld wachten.

Kortom, de ondernemer heeft niet alleen vertrouwensproblemen, hij heeft ook coördinatieproblemen. De ondernemer is iemand met verschillende petten op: hij is niet alleen verkoper of koper, maar ook nog werkgever, belastingbetaler, debiteur van een bank etc. Hij bevind zich in een positie waarin hij in verschillende sociale praktijken tegelijk is geïnvolveerd, die ook nog onderling verbindingen hebben. Als er op één van deze fronten iets mis gaat, kan het zijn dat alle schoteltjes van de stokjes vallen. Vaste opdrachtgevers of klanten kunnen deze taak aanzienlijk vergemakkelijken. Enige zekerheid op het vlak van de klandizie brengt ook meer rust in andere onderdelen van de bedrijfsvoering en kan veel 'onnodige' fricties voorkomen. Ze kunnen er voor zorgen dat de verschillende praktijken goed op elkaar aansluiten of in ieder geval elkaar niet verstoren. Dit kan de efficiency van de bedrijfsvoering ten goede komen.

\subsection{Partnerschap (1): bescherming tegen contingenties}

Een element dat regelmatig als essentieel gezien wordt, is iets dat in een andere context 'empathie' genoemd zou worden. De 'goede partner' geeft er blijk van zich rekenschap te geven van en in te spelen op de positie en de behoeften van de ander, en dat wil vooral zeggen: de klant. In het onderzoeksmateriaal zijn diverse elementen van dit zogenaamde 'partnerschap' naar voren gekomen. Hoe is men een goede partner? Goed partnerschap is meer dan alleen dat men bewezen heeft het beloofde ook te kunnen presteren. Dit is de elementaire vertrouwensbasis:

7 Het gaat hier niet om allocatieve efficiency, maar om 'X-efficiency', dat wil zeggen: "those abilities to plan and programme, to cooperate without bitchiness in production, to avoid waste of time or materials": aldus Dore (1992) Gooduill and the spirit of market cappitalism, p. 172. 
men ontwikkelt met elkaar de ervaring, dat de zaken waar het in eerste instantie om gaat, in orde zijn: kwaliteit, prijs, stiptheid in levering en betaling. Wat kan er nog meer verlangd worden? Uit verschillende interviews bleek het bijvoorbeeld om het volgende te gaan:

- een goede partner zal trachten, bijvoorbeeld door tijdig te waarschuwen, zijn relatie voor schade te behoeden;

- als het bedrijf door onvoorziene omstandigheden voor de noodzaak wordt geplaatst een belangrijke (en te behouden) klant ter wille te zijn (bijvoorbeeld een zeer scherpe prijs of een zeer korte aflevertermijn), beschikt de goede partner over de 'flexibiliteit' om daar effectief op in te haken;

- goede partners springen bij in het geval van calamiteiten, zoals brand in de fabriek. Dit element van partnerschap wijst mogelijk op een aspect van het ondernemerschap dat hier niet sterk genoeg is benadrukt, namelijk dat de plannen van de ondernemer altijd door onverwachte gebeurtenissen (tegenslagen of kansen) doorkruist kunnen worden, die hij niet kan voorzien of beheersen. Economen noemen dit 'onzekerheid', ter onderscheiding van 'risico', dat wel te berekenen (en vaak ook te verzekeren) valt. ${ }^{8}$ Wanneer men zich van deze onzekerheid bewust is, kunnen duurzame relaties voorzien in enige solidariteit voor het geval het lot toeslaat.

\subsection{Partnerschap (2): bescherming tegen concurrenten}

Het opnemen van de relatie met concurrenten als mogelijke bron van conflictstof levert betrekkelijk weinig op in vergelijking met de andere relaties. Wel geeft het enig zicht op hoe concurrentie, in ieder geval een deel ervan, verloopt. Het is gebleken dat duurzame relaties bescherming bieden tegen concurrenten. Dat gaat als volgt. In een goede 'partnerrelatie' is sprake van een zekere mate van loyaliteit, inhoudende dat de partner niet abrupt de relatie kapt voor een aantrekkelijker bod van een concurrent. Er wordt kennis van het aanbod genomen en het wordt vervolgens aan de leverancier voorgelegd met het verzoek om te overwegen wat er qua prijs of kwaliteit 'gedaan kan worden'. Hier is de leverancier duidelijk in het voordeel ten opzichte van zijn concurrent. Allereerst omdat de opdrachtgever hem kent en voorts omdat hij mede op grond daarvan een onderhandelingsmarge heeft bij het doen van zijn aanbod. Ook hier zullen uiteraard de afhankelijkheidsverhoudingen een variërend gewicht in de schaal leggen.'

8 Berger (1994) The economy and the environment, p. 783. Het element 'onzekerheid', vooral met betrekking tot de ontwikkeling van vraag en aanbod, wordt met name door Von Mises centraal gesteld in zijn conceptie van het 'ondernemerschap'. Cf. Swedberg (2000) Entrepreneurship, p. 20.

9 Cf. Powell (1990) Neither market nor hierarchy, p. 305. 


\subsection{Partnerschap (3): kwaliteit}

Bij een belangrijk deel van de kunststofverwerkende bedrijven heeft men zich legeven in duurzame relaties van een welhaast feodale signatuur. De betrouwbarheid van een belangrijk deel van de klanten en toeleveranciers staat door bin omvang op voorhand vast.

Voor de gang van zaken op het vlak van probleempreventie in dit segment wn de kunststofverwerkende industrie is van groter belang - zo kan men uit de inftviews concluderen - dat men werkt in een context waarin de standaard van $\mathrm{c}^{\mathrm{l}}$ tractsconformiteit buitengewoon hoog is. Dat geldt in de eerste plaats voor de bedrijven die als vaste toeleveranciers behoren tot het productienetwerk van $\mathrm{n}$ ternationaal opererende assemblers. Deze opdrachtgevers werken onder zeer strkte kwaliteitsregimes en stellen alles in het werk - vooral ook in de relatie met $h^{\text {in }}$ toeleveranciers - om ze daadwerkelijk te realiseren. Daarom dient het bedrijf $\mathrm{fls}$ toeleverancier van halffabrikaten of onderdelen van deze grote concerns) zovel mogelijk factoren uit te schakelen die in dit opzicht een probleem zouden kunn ${ }^{n}$ veroorzaken. Alleen als het bedrijf door de opdrachtgever daartoe in staat geaet wordt (soms zelfs tot uitdrukking gebracht middels een eigen cerrificeringsteem) kan het bedrijf als leverancier worden 'aanvaard'. Deze bedrijven kunnen het door de klanten gewenste resultaat alleen bereiken door alle bijdragen daartoe van de klant, de leverancier en de eigen organisatie daarop af te stemmen en afgestemd te houden. Meestal komt dit samen in een of ander kwaliteitssysteem, waarmee door permanente monitoring, evaluatie en bijsturing van alle relevante processen de gewenste prestatie geleverd blijft.

In feite zijn dergelijke resultaten afhankelijk van het welslagen van de samenwerking van alle partijen - maar met name van bedrijf en klant - over een langere periode, dat wil zeggen binnen het bestek van duurzame relaties. Door intensieve samenwerking met de klant en soms ook met de leverancier op het vlak van de productontwikkeling en -specificering en op dat van de kwaliteitszorg tijdens de productic, kan de gewenste prestatie geleverd worden. De grote assemblers domineren de andere spelers en zijn zo ook in staat om - zoals Elias heeft gesteld - de uitkomst van het spel te bepalen. ${ }^{10} \mathrm{Ze}$ stellen hoge eisen aan allerlei aspecten van de bedrijfsvoering binnen de ondernemingen waarmee in zee wordt gegaan. De bemoeienis van de opdrachtgever betreft soms ook de keuze van de toeleveranciers van het kunststofverwerkende bedrijf, meestal grote chemieconcerns waarmee - zo lijkt het - over het hoofd van het bedrijf heen goede relaties worden onderhouden. Dit alles wordt gedaan om te verzekeren dat een precies gespecifi-

10 Elias (1971) Wat is sociologie?. p. 87 e.v. 
ceerd product geleverd kan worden. Hier te spreken van 'partnerschap' doet eufemistisch aan. De contractuele verhoudingen waar het hier om gaat hebben duidelijk de hiërarchische trekken waarop Stinchcombe heeft gewezen. ${ }^{11}$ De keerzijde van deze medaille is, dat wie de status van toeleverancier heeft weten te verwerven en tot zo'n netwerk mag toetreden, ook vrijwel zeker is van interessante en soms enkele jaren lopende opdrachten, die doorgaans zonder mankeren worden betaald. Bovendien wordt het bedrijf kandidaat voor meer van dergelijke veeleisende opdrachten, ook van anderen. Het bedrijf doet dan ook meestal zaken met verschillende van dergelijke opdrachtgevers tegelijk.

De grote concerns (opdrachtgevers en toeleveranciers) lijken de toon te zetten voor de hele branche, want ook de minder omvangrijke en wijdvertakte opdrachtgevers zijn veeleisend en de bedrijven zijn er op ingesteld daaraan te voldoen. Het gevolg van deze hele constellatie is, dat de frequentic van problemen over en weer in deze branche doorgaans zeer laag is.

\subsection{Ontbinding van economische bindingen}

De economische bindingen in het bedrijfsleven, ook de hechte 'partnerschappen' waarvan men spreekt, kunnen met ontbinding worden bedreigd. Economische bindingen kunnen op diverse klippen lopen, zo blijkt uit de interviews.

Allereerst kan het zijn dat niet meer aan de gestelde verwachtingen wordt voldaan. Volgens de regels van het kwaliteitsspel worden teleurgestelde verwachtingen onderwerp van uitdrukkelijke periodieke bespreking. Wanneer de prestaties niet aan de verwachtingen blijven voldoen kan dat aanleiding zijn de 'relatie' van de vaste lijst te schrappen. Voorts kan het zijn dat zich een aantrekkelijker relatie presenteert. Het gaat dan meestal om een aantrekkelijker prijs. Volgens de regels van het partnerschap wordt de vaste relatie van de offerte op de hoogte gesteld met het verzoek de eigen prijs aan een nader onderzoek te onderwerpen. Maar als de partner daartoe niet in staat of bereid blijkt kan het partnerschap in gevaar komen.

Soms zijn het gebeurtenissen aan het andere eind van de wereld die de relatie in gevaar brengen. Een voorbeeld daarvan trof een van de kunststofverwerkende bedrijven. Een acute economische crisis, die zich vanuit Zuid-Amerika snel verspreidde, had tot gevolg dat de concurrenten van een grote opdrachtgever producten voor een aanzienlijk lagere prijs op de markt konden brengen. Dat bracht de opdrachtgever, met wie het bedrijf al jarenlang een zeer nauwe relatie onderhield, er toe bestellingen bij het bedrijf tot nader order op te schorten totdat er een 
manier zou zijn gevonden om de concurrentie op dit punt het hoofd te biede. Deze stap van de 'partner' bracht het bedrijf in ernstige en kostbare moeilijktden. Niettemin werd na geruime tijd de draad tussen de bedrijven weer opgertmen.

In de tot dusverre genoemde voorbeelden gaat het vooral om incidenti. Maar nu tenslotte een enkele speculatieve opmerking over een vraag die in het $\mathrm{k-}$ der van de door Galanter en Rogers gestelde problematick (over de neergang vn duurzame relaties) interessant is: zijn er omstandigheden voorstelbaar die ecortmische bindingen structureel op scherp zetten? Het zou dan moeten gaan om en ontwikkeling die de verschillende en sterke gronden voor vaste relaties in de schduw plaatst. Uit enkele gesprekken blijkt dat zo iets kan gebeuren als de prijs kt enige relevante beslissingscriterium wordt in het zakendoen. Dat kan bijvofbeeld gebeuren als in een recessie de marges voor een langere tijd onder druk kmen te staan. Maar ook in dergelijke omstandigheden kunnen na enige tit. waarin productieve overcapaciteit wordt opgeruimd, de duurzame relaties wit terugkomen.

\section{Het gewicht van de juridische infrastructuur}

Een van de onderzoeksvragen was of het bestel van faciliteiten voor het doen van juridische stappen van invloed is op het gebruik van reflexieve methoden en voorts op het omgaan met storingen en geschillen in de relaties tussen de bedrijven

In Nederland bleek in geen van de branches de inzet van reflexieve methoden in hoofdzaak een reactie op enige kwaliteit van gerechtelijke faciliteiten. Het leek voorts niet erg waarschijnlijk dat de zakenrelaties in een branche als de kunststofverwerking meer of minder geschillen zouden genereren en naar aanleiding daarvan meer of minder juridische stappen zouden doen wanneer de juridische infrastructuur er hogere of lagere drempels aan zou opwerpen. Voor de bouwnijverheid zou dat mogelijk anders kunnen liggen.

Om over deze aan het Nederlandse materiaal ontleende vermoedens meer uitsluitsel te krijgen is voor deze twee zo tegengestelde bedrijfstakken aan het onderzoek een vergelijkend element toegevoegd. Daartoe zijn ook bedrijven uit deze bedrijfstakken in de Belgische en Duitse regio's aan weerszijden van Zuid-Limburg benaderd.

Het gebruik van de reflexieve methoden waarmee bedrijven storingen trachten te voorkomen bleek niet merkbaar afhankelijk van de juridische infrastructuur. Vanuit de optiek van de 'geschillenpiramide' zou dit streven kunnen worden geduid als gericht op het 'voorkomen of vermijden' van juridische en ge- 
rechtelijke stappen. Dat zou echter een overhaaste conclusie zijn. Klachten zijn voor de bedrijven niet noodzakelijk rechtsproblemen en gerechtelijke procedures in wording. Vanuit hun perspectief kunnen klachten een heel andere betekenis hebben. Dat geldt het sterkst voor de kunststofverwerking. Klachten worden daar in beginsel beschouwd als waarschuwing, omdat ze mogelijk een stap vormen op weg naar een verbroken relatie.

Hoe met klachten wordt omgegaan zal derhalve sterk afhangen van het belang dat aan de relatie wordt gehecht. Gaat het om een vaste relatie, dan dienen klachten meestal snel en naar tevredenheid van de klagende relatie uit de wereld te worden geholpen. Nog beter is het ze te voorkomen. Macaulay wees er al op dat de vrees voor het verliezen van een goede relatie (en een goede reputatie) bedrijven veelal doet vermijden wat daartoe zou kunnen leiden. Deze perceptie wordt in dit onderzoek in grote lijnen bevestigd. Daar komt bij dat een dergelijke opstelling niet alleen een kwestic van de prudentic van het bedrijf is, maar in sommige gevallen een harde (en te objectiveren) voorwaarde is die grote opdrachtgevers aan hun toeleveranciers stellen. De zeldzaamheid van het ondernemen van "juridische stappen' in dergelijke relaties is derhalve beter te kenschetsen als een onbedoeld gevolg, dan als een beoogd resultaat van preventie.

Het streven naar de preventie van storingen kan inherent zijn aan economische bindingen en kan als zodanig onafhankelijk zijn van de kwaliteiten van een juridische infrastructuur. Het is voorstelbaar dat een verdere verspreiding van de hier besproken reflexieve methoden, in het kielzog van het grootbedrijf, het klachtenvolume in commerciële relaties verder zal reduceren. Aan de methoden die daarbij behulpzaam kunnen zijn wordt in ieder geval gewerkt. ${ }^{12}$

De verschillen in juridische infrastructuur tussen Nederland, Belgiè en Duitsland blijken, voor de manier waarop men in de kunststofverwerking met storingen omgaat, geen merkbare gevolgen te hebben. Het is de partners in deze

12 In bedrijfskundige kring wordt bijvoorbeeld een speciaal 'klachtenmanagement' ontwikkeld. Dat is de naam voor een organisatorisch kader voor het accepteren, analyseren, registreren en beoordelen van klachten, het aanbieden van een oplossing van klachten en evalueren van de oplossingen. Voorts is er ook voorzien in de mogelijkheid om middels analyse van de verzamelde gegevens over klachten de frequentie van klachten te reduceren. Bij de gestandaardisecrde ISO-terminologie van 'gebreken' en 'afwijkingen' voegt zich hier een terminologie rond de 'klacht', die waarschijnlijk over enige tijd - bij de koplopers althans - alle 'problemen' , 'moeilijkheden' en 'onregelmatigheden' uit het spraakgebruik zullen gaan verdringen. Ook lijkt de waardering van 'problemen' etc. bij de transformatic tot 'klacht' een verandering te zullen ondergaan. Ze zijn niet iets negariefs, iets vervelends of iets om bang voor te zijn. Klachten dienen juist van een positief label voorzien te worden. Een klacht is volgens deze optiek een ' gratis advies' of zelfs een 'geschenk' van de klager. Over reflexiviteit gesproken. Cf. Starreveld en Thomassen (1999) Klachtenmanagement (1); Barlow and Moeller (1996) A complaint as a gift. 
branche er veel aan gelegen storingen in het algemeen en zeker problematische storingen te voorkomen, vooral omdat hun opdrachtgevers dat eisen. Wannetr zich toch problematische storingen voordoen wordt de kwestie meestal in overlg afgedaan. Conflicten worden vermeden. Als er conflicten ontstaan tracht men $z$, eventueel met een inschakeling van een onafhankelijk laboratorium, in sametwerking op te lossen. Aan het doen van juridische stappen komt men zelden tot. Noch in Duitsland waar civiele procedures doorgaans korter, noch in België war ze doorgaans langer tijd in beslag nemen dan in Nederland, is het patroon van het voorkomen van en omgaan met storingen anders dan het patroon dat in Nederland voor deze bedrijfstak is geschetst.

Voor de hoofdaannemers in de bouwnijverheid blijken de verschillen in jurdische infrastructuur van meer gewicht. Ook in deze bedrijfstak is kwaliteitszog niet een uitvloeisel van onvrede met juridische voorzieningen. Maar ook in beide buurlanden blijken deze inspanningen, overigens om ongeveer dezelfde redener als in Nederland, niet te kunnen voorkomen dat er zich regelmatig storingen et ook geschillen voordoen. Dat ligt voor een belangrijk deel aan technische gegevenheden en de aard van de relaties. Maar voor een moeilijk te bepalen deel lijlt

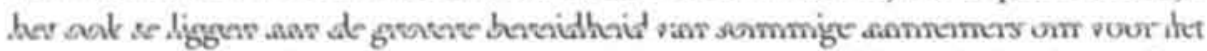
risico van een conflict niet terug te schrikken. De vrijwel branchebrede conflictvermijding die in de kunststofverwerking te signaleren valt is in de bouwnijverheid minder algemeen. Bij de afwikkeling van deze geschillen zijn de mogelijkheden voor het doen van juridische stappen wel van belang. Wat in de verhalen daarover allereerst opvalt is dat vooral de duur van een gerechtelijke procedure de doorslaggevende factor is. De tijd die een procedure doorgaans neemt vindt men eigenlijk al snel te lang. Die looptijden worden overigens in de gesprekken wel enigszins gechargeerd. Wanneer de looptijd van een procedure meer is dan één of twee jaar, duurt de procedure voor de meeste aannemers gewoon te lang. Daarna maakt het niet meer veel uit of een procedure vijf of tien jaar duurt. Dergelijke verschillen zijn dan meestal niet meer relevant. Onaantrekkelijk blijft onaantrekkelijk. Maar dit is blijkbaar geen volstrekt waterdichte logica. Een enkele Duitse aannemer bleek niettemin vrij veel te procederen, mogelijk als gevolg van een iets minder strikte selectie van opdrachtgevers. Daarnaast bleken sommige (waarschijnlijk kapitaalkrachtige) Belgische aannemers toch enkele jarendurende procedures te hebben lopen, naar verluidt met het oog op het incasseren van de aanzienlijke wettelijke rente.

Overigens kwamen de verschillen tussen de landen op macroniveau niet duidelijk tot uitdrukking op het microniveau. $\mathrm{Er}$ vielen nergens klaarblijkelijke moeilijkheden te signaleren met het vinden van juridisch advies of juridische bijstand bij het ondernemen van juridische stappen. Ieder leek wel een lokale advocaat beschikbaar te hebben als het nodig was. Voor een enkel bijzonder geval werden specialisten gemobiliseerd. 


\section{Burgerlijke rechtspraak tussen vraag en aanbod}

Ondanks het feit dat er veel (ofschoon niet in elke bedrijfstak evenveel) werk gemaakt wordt van de preventie van klachten en geschillen, komt het voor dat bedrijven te maken krijgen met juridische en gerechtelijke stappen. Ook daarbij zijn er duidelijk verschillen tussen de bedrijfstakken te constateren, overigens meet qua volume dan qua materie. Om wat voor zaken gaat het? Of, om in de terminologie te spreken die in hoofdstuk twee is gebruikt: welke 'vraag' wordt er gegenereerd?

In de kunststofverwerking is het beroep op civiele rechtshandhaving in verband met de hier onderzochte relaties zeer bescheiden. Het gaat om enkele zaken in verband met een faillissement of een schending van een patent. In het eerste geval valt er aan de relatie weinig meer te redden en derhalve blijft er weinig anders over dan de rekening te vereffenen. In het tweede geval is er acuut gevaar en dat is dan aanleiding om direct zwaar geschut in stelling te brengen. Tenslotte zijn vooral voor bedrijven met kleinere klanten incassokwesties onvermijdelijk. Kwesties inzake productaansprakelijkheid worden meestal door de verzekeringsmaatschappij afgehandeld; in hoeverre daaruit procedures voortkomen blijft aan het zicht onttrokken. De verzekeringsmaatschappijen zijn vooral prominent aanwezig bij het wegtransport. Schadekwesties komen in deze branche regelmatig voor en worden vooral doorverwezen naar de verzekeringsagent. Daarmee verliest men het zicht op (en naar het lijkt ook de interesse voor) wat die er mee doet in termen van gerechtelijke stappen. In de bouwnijverheid krijgt men in zakelijke relaties regelmatig te maken met juridische stappen. Met name het opeisen van achtergehouden betalingen in verband met 'discussies' over meerwerk en beweerde gebreken bij oplevering komt regelmatig voor.

Terwijl het gerecht in de andere branches 'ver van het bed' lijkt te liggen, zijn aannemers geïnformeerd over de gang van zaken bij de rechtbank en de Raad van Arbitrage. En waar er in de eerste twee branches weinig ontevredenheid valt te beluisteren over de gerechtelijke faciliteiten die beschikbaar zijn, wordt er in de bouwnijverheid wel geklaagd, met name over de afhandelingsduur van procedures in België en Duitsland. De klachten zijn wel begrijpelijk: rechtshandhaving wordt op die manier een lege belofte. Bij de Nederlandse bedrijven werd minder geklaagd over de afhandelingsduur. Maar hier is doorgaans weer geen rechterlijke instantie met de behandeling belast.

$\mathrm{Nu}$ dateren dergelijke klachten waarschijnlijk niet van vandaag of gisteren, ook niet in Nederland. Sinds de negentiende eeuw zijn voorstellen gedaan om de 
traagheid van civiele procedures te verhelpen. Dergelijke voorstellen hebben volgens Eshuis echter zelden tot wetswijzigingen geleid. ${ }^{13}$ De vertaling van de 'vraag' in 'aanbod' is dus verre van een automatisme. Hoe die verhouding er dan wel uitziet is vooral een interessant thema voor verder onderzoek. Mocht zulk onderzoek geëntameerd worden, dan kan naar mijn mening een perspectivistische benadering van rechtspraak, zoals geschetst in hoofdstuk 2 , daarbij goede diensten bewijzen. Volgens deze benadering zijn bepaalde gerechtelijke praktijken het best te begrijpen, door de dynamiek van het krachtenveld rond die praktijken en het daarin levende ideeëngoed voor een langere periode te bestuderen. Ook het hier beschreven project heeft enkele vragen doen rijzen die voor dergelijke onderzoek in aanmerking komen.

De eerste kwestie betreft de persistentic van de lange afhandelingsduur door gerechten, bijvoorbeeld zoals die in bouwgeschillen in België. Het lijkt te gaan om een onveranderlijk gegeven. ${ }^{14}$ De vraag is dan welke groeperingen deze bestendige praktijk om welke redenen in stand houden. Naast de rechterlijke macht en advocatuur zal ook de aandacht op politieke en ambtelijke groeperingen moeten worden gericht. En hoe zit het met de invloed van de brancheorganisatie? De ondervraagde Belgische aannemers klonken weliswaar kritisch, maar leken de gang van zaken op te vatten als een gegeven omstandigheid. Overigens wekten ook de Nederlandse aannemers de indruk zich weinig gedachten te maken over het waarom van arbitrage of over mogelijke alternatieven.

Dat brengt ons op een tweede kwestie: waarom komt men in België en Duitsland nu pas met voorstellen voor arbitrage voor bouwkwesties? ${ }^{15}$ Waarom hebben de brancheorganisaties aldaar dat niet al honderd jaar geleden voor elkaar gekregen en waarom is dat in Nederland in 1907 wel gelukt? Was dit misschien een uitwerking van het beginsel van 'soevereiniteit in eigen kring' of gewoon bestuurlijk pragmatisme? En wat is er nu ineens in Duitsland en België veranderd: is dit een uiting van de voortschrijdende terugtred van de overheid?

Het zijn kwesties die het bestek van dit onderzoek te buiten gaan en we zullen ze dus verder laten rusten. Maar het zijn intrigerende vraagstukken waarop onderzoek van de vraagzijde geen antwoord kan geven. Onderzoek van de aanbodzijde zou hierin kunnen voorzien. Het is in dit onderzoek echter gebleken dat ook onderzoek van uitsluitend de aanbodzijde beperkingen heeft. Ontwikkelingen an

13 Eshuis (1998) Een kuestic tan tijd, p. 12. Zie voor cen recente verkenning van de wensen aan de ' vraagzijde' : Werkgroep Effecten Rechtspraak (1998) Maatschappelijke effecten van verbetering. 14 Huysse sprak er al over in 1989, en ook toen leek het geen nieuw gegeven. Cf. Huyse (1989) De kleur van het rechi, p. 76.

15 Projectgroep 2000 (2001) Justitic in beurging. p. 25 en Dieckmann (2000) Neue gesetzgeberische Wege eur anseengerichrlichen Srreisschlichrung. 
de vraagzijde, zoals die op het gebied van kwaliteitszorg, kunnen zich onafhankelijk voltrekken van wat de gerechtelijke infrastructuur te bieden heeft. Niettemin kan de vorming van de gerechtelijke infrastructuur door dergelijke ontwikkelingen worden beīnvloed. Op die ontwikkelingen kan onderzoek van de aanbodzijde weer geen zicht geven. Beide typen onderzoek zijn derhalve complementair.

\section{Resumerend}

Wat heeft het onderzoek nu kort gezegd opgeleverd? De cerste vraag van het onderzoek betreft het bestaan en gebruik van reflexieve methoden voor de probleempreventie in relaties tussen bedrijven. Het is gebleken dat dergelijke methoden inderdaad bestaan. Het gaat vooral om kwaliteitszorg volgens een ISO-standaard of een standaard van een grote opdrachtgever. Dergelijke methoden worden door een vrij groot deel van de hier onderzochte bedrijven gebruikt en kunnen onder bepaalde omstandigheden zeer succesvol zijn. Deze omstandigheden zijn vooral: technologische kenmerken van product en productie, het bestaan van duurzame relaties en constante stromen van opdrachten en een sterke motivatie bij het management om resultaat te boeken met de reflexieve methoden. Het hebben van de beschikking over een certificaat lijkt echter geen voldoende waarborg voor een effectief gebruik van de methode.

Het tweede onderzoeksthema heeft betrekking op de mogelijke relatie van het in zwang komen van deze reflexieve methoden en het gesuggereerde verdwijnen van duurzame relaties in het economisch verkeer tussen internationaal opererende bedrijven. Er zijn geen aanwijzingen gevonden voor het verdwijnen van dergelijke relaties, integendeel. De verwevenheid van de bedrijven in de kunststofverwerking met hun opdrachtgevers en leveranciers blijkt soms van een indrukwekkende complexiteit. Waar dergelijke relaties niet worden aangetroffen, zoals in de bouwnijverheid, hebben ze waarschijnlijk ook nooit bestaan. Het gebruik van reflexieve methoden blijkt weinig te maken te hebben met verdwijnende duurzame relaties in het bedrijfsleven, maar meer met eisen van dominante opdrachtgevers en bedrijfsmanagers met ambities op dit vlak.

Het laatste onderzoeksthema betreft de vraag naar de invloed van de juridische infrastructuur op het gebruik van reflexieve preventiemethoden en op de frequentie van het doen van juridische stappen in het zakenleven. Dat reflexieve methoden worden gebruikt met het oog op de aan rechtshandhaving verbonden kosten heb ik niet kunnen vaststellen. Voor dat gebruik bestaan andere, hierboven genoemde redenen. Als het gebruik van reflexieve methoden de frequentie beperkt waarmee juridische stappen worden ondernomen, dan is dat vooral een onbe- 
doeld gevolg van deze methoden. Als er eenmaal geschillen zijn ontstaan blijkea de kenmerken van de rechtshandhavingsvoorzieningen wel van betekenis voor de beslissing om al dan niet gerechtelijke stappen te ondernemen. Die betekenis blijkt overigens vooral de resultante van soms zeer opmerkelijke calculaties te zijn. 


\section{SUMMARY}

\section{Where legal steps are rare: controlling complaints and disputes in business relations.}

\section{Introduction}

This project builds on the author's earlier research that revealed the existence of methods used to control the frequency of debt-enforcement and related civil litigation. These methods were used by mail-order firms and other 'customer-processing' firms such as banks, in order to select 'desirable' (i.e. solvent and loyal) customers and functioned by means of customer profiles, that were constructed on the basis of statistical data that were either routinely derived by the companies themselves from their sales experience or bought from other firms that were in the business of selling statistical data on customer populations. It was rather eerie witnessing an interviewee of a mail-order firm whom I provided with my home address, zooming in on my data and within seconds hearing his verdict on my status as a reliable prospective customer.

These findings prompted the question, whether or not this kind of preventive methods would also be used by firms with regard to inter-business relations. In theory the use of these methods seemed feasible, assuming that much business involves repeated deals. But were they actually used in practice? And if so, how were they related to the frequency of problems, disputes and civil litigation in business relations? In fact, I was going out on a limb to research this question, because the answer might well have been negative. Luckily, the first interviews brought some practices to my attention, that were unknown to me, but that turned out to be very relevant to the initial question, and justified further travels into business land.

The most surprising finding was the use of quality-systems such as the ISO-standards, elaborate organisational practices used to increase customer satisfaction by fine-tuning production processes in order to minimise the occurrence of defaults and defects. These and similar methods are interpreted as instances of 
a wider phenomenon, that Giddens referred to as 'reflexivity' and which he considered an important characteristic of contemporary society. In the present report these methods are indicated as 'reflexive methods'. They can be regarded as a kind of organisational 'learning processes', that make use of the collection of statistical data about the organisation and the relevant context in which it operates. In the organisation the data are used to direct, and if necessary redirect, organisational practices. Reflexive methods can be found in private as well as public organisations. The expanding capacity and declining costs of information technology are responsible for the fast diffusion of these methods.

\section{Questions}

Thus, the first research topic concerned the existence, characteristics and effectiveness of 'reflexive methods' meant to prevent recurring problems (such as defaults and defects) in inter-business relations. This begged the question, how problems and disputes that nevertheless occurred are dealt with and, more particularly, whether or not they serve as grounds for litigation. These research questions refer to a prominent field of socio-legal study, namely the dispute and litigation studies. It seemed worthwhile to analyse some assumptions of this literature, especially about the nature of courts. In Chapter $2 \mathrm{I}$ argue that the images of courts implicit in this literature emphasise their function for 'society', either conceived as the 'social system' (conflict resolution, social control) or the general citizenry (protection of rights). What is neglected are the ambitions and interests that are inherent in the state, such as in the positions of administrators, political actors or the judiciary itself. These ambitions and interests have been very important in shaping courts into what they are. Ignoring this element results in a truncated image of what courts are about. I suggest that courts should be regarded as institutions that have been shaped by the formation process of the modern state. I do not suggest the replacement of one biased perspective of courts by another. Instead, a perspectivist approach to courts is suggested, in which they are conceived as institutions that can perform a multitude of functions for various groups and factions on the 'demand side' as well as on the 'supply side'. The assumption of over-determination seems more adequate than a limited set of functions. The demands made on courts by actual litigation constitute only one of the forces that shape the formation of courts, although on occasion their influence may be decisive. As historical studies show, other forces on the 'supply side' have had an important impact too.

An inquiry into the aspects of business relations mentioned earlier, can also serve to contribute to two other socio-legal themes. The second research topic ta- 
kes its cue from reports of increased business litigation since the 1980's, that was supposedly rooted in the decline of 'long-term continuous' relations in international business. The question for this project is whether or not continuous relations still exist in business relations, and whether they might be related to the reflexive methods of problem-prevention described.

The third research topic concerns a debate about the causes of the different national litigation rates. The different levels of civil litigation can, according to $\mathrm{Ka}$ washima, be explained from cultural peculiarities of the countries involved. These cultural differences result in differences in demand for litigation. According to others, such as Haley and Blankenburg, the differences are not the outcome of demand but mainly of supply. It is the existing legal infrastructure that makes people accommodate to the claims it encourages or discourages. The importance of the legal infrastructure for the use of reflexive methods and the resort to legal steps in dealing with disputes constitutes the third research topic. These topics are listed in the introductory Chapter 1 and further developed in the first part of Chapter 3.

\section{The research}

As described in Chapter 3 the collected data provide the basis for tentative answers to the research questions. The data have been gathered by means of extensive interviews with owners or chief managers of small and medium sized Dutch, Belgian and German corporations. These data allow for the reconstruction of the conditions (relational or otherwise) that can explain the use and effect of reflexive methods to control complaints and disputes. These conditions, combined of course with the wish to stay in business in the long run, constitute the 'logic' of a particular entrepreneurial position. An important element of this position is the network of relations with suppliers, clients, staff and many others that has to be mobilised. This network enables the enterprise to function effectively, for its success depends to a large extent upon the co-operation of this relational network. But it also restricts the enterprise, because the wishes of the suppliers, clients, staff etc. have to be taken into account. For this reason the main focus of the interviews was upon business relations: with suppliers and customers. Also the relations with competitors were selected in order to investigate how these might affect continuous business relations. Information was collected about the firm, its products and production process, and about the incidence of legal steps in disputes with suppliers, clients and competitors. Most attention was directed to addressing the nature of these three relationships and how complaints and disputes in these relations were prevented or dealt with. To detect the relevance of legal infrastruc- 
ture for the use of reflexive methods and dealing with complaints and disputes, an element of international comparison had to be included.

The first step in the project was confined to The Netherlands, to the area around Maastricht. It concerned the selection of branches of industry that showed some relevant variation: (a) in the frequency of trouble and disputes in business relations, and (b) in the scope of activity (national/regional or international). There was no easy way to decide whether industries showed this variation for the first criterion, so a combination of expert opinion and trial and error had to do the trick. The report covers three branches of industry selected for research. The strongest contrast appeared in the 'plastics' industry and the 'construction' industry, the first being almost free of friction in business relations and internationally active, the latter rife with friction and operating regionally or nationally. The road transport industry appeared to take a position in between these extremes of friction, and to operate chiefly internationally. To allow a sufficiently reliable reconstruction of the various entrepreneurial positions, a small number (6) of firms from each selected branch of industry had to be interviewed. A second step in the project was to provide for variation in legal infrastructure, to fathom its importance in deciding about the use of a quality-system and about taking legal steps in disputes. This has meant the inclusion of interviews with firms of the most contrasting branches (plastics and construction) in the area around Aachen (in German Northrhine-Westphalia) and around Hasselt (Belgium).

\section{Answers}

Chapters 4 and 5 give a detailed account of the research findings and in Chapter 6 the conclusions are drawn. They can be summarised as follows. The first research question concerned the use and character of reflexive methods to prevent complaints and disputes. The prevention of complaints - especially coming from customers - is implemented by a variety of methods, some of which fit the definition of reflexive methods. Traditional methods mentioned included the selection of reliable business partners, written and detailed contractual agreements, and the implementation of delivery controls. The ISO-quality-systems came to the fore as the most widely used reflexive methods in the branches under investigation. The plastics industry appeared to be especially quality minded. Not only most Dutch but also most of the German and Belgian companies in this branch had acquired one of the ISO-certificates. Some examples of quality-systems were found that were operated by large customer-corporations, e.g. in the computer industry and the automotive industry. 
The exploration of the effectiveness of these methods is discussed in connection with an explanation of the different levels of friction that the three industrial branches reported. With this explanation also the second research question about the existence of continuous relations is answered. The interviews revealed several conditions that can make a contribution to a low level of friction in business-to-business relations. The first set of conditions consists of the technical qualities of the product and the production process. The characteristics of products can influence the risk of defaults, as is reportedly the case with e.g. wood, rubber and concrete. Production technology can also limit the possibilities for 'organisational learning' when the products are produced, not as series of identical items (as in the plastics industry) but as individualised products. A second condition is the possibility of, or choice for, the maintenance of long-term continuous relations with business partners. Long-term relations facilitate the tracking and removal of sources of nonconformity. Moreover, continuous relations appeared much favoured in general for a variety of reported advantages. But sometimes continuous relations are simply an impossibility, e.g. when individualised products are sold to one-time customers, like in the construction industry. These two elements are to a large extent 'given' circumstances that define the possibilities and impossibilities of efforts to prevent trouble in business-to-business relations. This brings us to the third condition: the degree of motivation to actually prevent nonconformity. Strong motivation seems essential for a low level of nonconformity. Motivation seems strongest when either customers are in the position to demand a high standard of conformity (such as a particular default limit per million parts) and are known to 'enforce' them, or the firms take a high conformity standard seriously for other reasons (such as a reduction of production costs). This implies that quality certificates do not necessarily guarantee an effective complaint and dispute prevention. Prevention must be backed by a strong motivation (self-directed or other-directed) to make it work.

These conditions provide the elements of the entrepreneurial logic for the different branches of industry that have been studied. In the plastics industry all conditions facilitate a high level of conformity: favourable technical conditions and a context of continuous relations with demanding customers and capable suppliers. As a consequence of this logic, the use of reflexive methods is general, serious and effective; and the reported level of complaints is relatively low. The complaints that nevertheless emerge, are dealt with in mutual consent, often according to a set routine. Disputes, especially with customers, are avoided whenever possible in order to avoid damage to the relationship. Litigation is rare in all three relations, and limited to cases where co-operation is not to be expected (as in debtenforcement and bankruptcy) or when a threatening situation arises (as in the case of violation of a patent by a competitor). This branch of industry provides a strong contrast with the construction industry: there the technical conditions are 
unfavourable, continuous relations are rare, as are dominant customers. Here, the effective implementation of a quality-system is mostly dependent on the resolution of the entrepreneur. This different logic results in a relatively high level of complaints, especially in relations with subcontractors and principals. In particular in the relation with the principals, disputes and also arbitration are not uncommon. They often concern payment for additional work (during the process of construction) and complaints about defects when the building is delivered up as finished. In between these extremes the road transport industry occupies an intermediate position. Production conditions are not completely under control, continuous relations with customers are prominent, and these customers seem only a little less demanding than customers in the plastics branch. Defaults and defects are, despite all planning and precautions, not completely avoidable, due to weather and traffic conditions and hurried drivers. Most of the complaints concern insured risks and are forwarded to the agents of the insurance companies.

The interviews revealed the presence of a considerable preference for long-term continuous relations in the branches of industry operating internationally. Considering the importance of the industrial sectors supplied by firms interviewed (e.g. automotive industry, computer industry, food industry), it seems beside the mark to proclaim the decline of long-term continuous relations in business. In fact, they appear to be vigorously alive today, at least as much as in the days of Macaulay's famous article of the sixties. The difference might be that these relations have become less personal, that trust has acquired a bureaucratic aspect, due to the reflexive methods that have become the fashion.

The last research questions concerned the importance of legal infrastructure for (a) the adoption of reflexive methods for the prevention of complaints, and (b) decisions to take legal steps in disputes, or to deal with them in another way. It is safe to state that the adoption of reflexive methods by the firms involved in this research appears to be not primarily inspired by considerations about the costs and benefits of legal enforcement of nonconformity. As the principle motives for this decision emerged the demands of dominant customers and the expectation of a reduction of production costs. The desired rewards are profitable business partnerships and cost reductions. These motives suggest that an effect of reflexive methods on the likelihood of disputes and perhaps even civil litigation is mainly unintended, and that legal infrastructure is not all-decisive. Changing social practices such as those described here can independently affect demand. But when disputes do emerge, the configuration of legal facilities does matter, although not always in a clear-cut way. Complex calculation can be involved. Especially the comparison of the three groups of construction companies was revealing in this respect. The Dutch building contractors generally use a standard-form contract that provides for arbitration in the case of a dispute. So if any legal steps are taken, they are directed at arbitration. This seems hardly a matter of choice. The time 
needed to conclude an arbitration procedure, which is estimated about a year, is reported to be acceptable. Still, some contractors say they prefer a settlement because of the costs that arbitration involves, and also because they know that a settlement is often the outcome of the arbitration procedure anyway. In Germany court litigation is the standard option for contract enforcement in construction disputes. Some German construction firms report a preference for settlement because of the long duration of court proceedings (which is about three years, including appeal), but evidently the amounts of money at stake prevent an easy decision. On the other hand one contractor seemed quite satisfied with the facilities to enforce contracts and reported more litigation than the others on e.g. debt, bankruptcy and the liability for defects. Also in Belgium court litigation is the standard option in the construction sector. Here, court delay is known to be prohibitive: some contractors even report periods of 5 to 10 years (including appeal) before a final decision is reached. No wonder they prefer a settlement. But despite all this, some professed to be quite prepared to litigate in some cases that they assumed they would win, because the official interest rates were considerably higher than the interest rates of the average savings account.

\section{Further research}

The research project has revealed considerable variation in litigation 'needs' in the context of business relations. The variation is more in volume than in substance. On the one hand, the demands made by the plastics industry were reported to be very modest, and concerned bankruptcy, patent protection and debt-enforcement. On the other hand the needs of the construction industry were substantially larger and chiefly concern debt-enforcement relating to disputed additional work and alleged defects, and also bankruptcy. The firms in the plastics industry and road transport do not complain about how these needs are met. But the contractors in the construction industry seem considerably less satisfied, and with reason. The delay Belgian and German court proceedings makes enforcement of rights an illusion. There appeared to be some satisfaction among Dutch contractors about the time involved in deciding construction disputes, but it has to be noted that these disputes are settled in arbitration and not in court.

Complaints about delay are old, and apparently 'unmet needs' are not automatically translated into some kind of institutional adaptation. The relation between 'demand' and 'supply' in this context, and especially the dynamics of supply, are research topics to be recommended. 



\section{LITERATUURLIJST}

Abel, R.L. (1973)

"A Comparative Theory of Dispute Institutions in Society" Law od Society Review, vol. 8, p. 217-347.

- (1980)

"Redirecting Social Studies of Law", Law \& Society Review, vol. 14, p. 805-829.

- (1982)

"The Contradictions of Informal Justice" R.L. Abel (ed.) The Politics of Informal Justice. Vol. 1. New York: Academic Press, p. 267-320

Aubert, V.(170)

"Law as a Way of Resolving Conflicts: the Case of a Small Industrialised Society", L. Nader (ed.) Law in Culture and Society. Chicago: Aldine, p. 282-304.

Barlow. J. en C. Moeller (1996)

A Complaint is a Gift: Using Customer Feedback as a Strategic Tool. San Francisco: Berrett-Koehler.

Berger, J. (1994)

"The Economy and the Environment" N.J. Smelser en R. Swedberg (eds.) The Handbook of Economic Sociology. Princeton: Princeton University Press, $p$. 766-797.

Black, D. (1976)

The Behavior of Law. New York: Academic Press.

Blankenburg, E.R. (1985)

"Indikatorenvergleich der Rechtskulturen in der Bundesrepublik und den Niederlanden" Zeitschrift für Rechtssoziologie, jrg. 6, p. 255-273.

- (1991)

"Legal Cultures Compared" E.R. Blankenburg, J. Comaille en M. Galanter (eds.)

Disputes and Litigation.. Onati Proceedings nr. 12.

- (1994) 
"The Infrastructure for Avoiding Civil Litigation: Comparing Cultures of Legal Behavior in the Netherlands and West Germany" Law \& Society Review, vol. 28, p. 789-808

Blankenburg, E.R. en J.R.A. Verwoerd (1987)

"Vermijden en benutten van civielrechtelijke procedures in Nederland en omringende landen" Justitiele Verkenningen, jrg. 13, nr.2, p. 20-35.

- (1989)

"Prozeszhäufigkeiten in den Niederlanden und in Nordrhein-Westfalen 1970-1984" E.R. Blankenburg (Hrsg.) Prozeszflut? Studien zur Prozesztätigkeit europäischer Gerichte in historischen Zeitreihen und im Rechtsvergleich. Köln: Bundesanzeiger, p. 257-333.

Blankenburg, E.R. en U. Reifner (1986)

Rechtsberatung. Soziale Definition von Rechtsproblemen durch Rechtsberatungsangebote. Neuwied: Luchterhand.

Blockmans, W.P. (2000)

Keizer Karel V 1500-1558: de utopie van het keizerschap. Leuven: Van Halewyck.

Bloembergen, A.R. (1995)

Ubi iudicia deficiunt incipit bellum. Het beroep op de rechter in onze volgroeide rechtsstaat.. Arnhem: Gouda Quint.

Blois, K.J. (1972)

"Vertical Quasi-Integration", R. Buckley and J. Michie (eds.) (1996) Firms, Organizations and Contracts; a Reader in Industrial Organization. Oxford: Oxford University Press, p. 320-339.

Bauman, Z. (1988)

"Is There a Postmodern Sociology?", Theory, Culture of Society, vol. 5, p. 217-237.

van den Bergh, R. en E. Dirix (1992)

Handels-en economisch recht. Antwerpen: Maklu.

van den Bergh, G.C.J.J. (1986)

"Over een theorie van sociale controle en het meten van recht" Recht en kritiek, jing. 12, p. 374-386. 
- (1987)

"Sociale beheersing, recht en maatschappelijke ongelijkheid. Op zoek naar een verborgen discours.", Beleid en Maatschappij, jrg. 14, p. 245-253.- (1994) Geleerd recht. Een geschiedenis van de Europese rechtswetenschap in vogelvlucht. Deventer: Kluwer.

Bruinsma, J.F. (1996)

Kadi-rechtspraak in postmodern Nederland. Zwolle: Tjeenk Willink.

van Caenegem, R.C. (1985)

Geschiedkundige inleiding tot het privaatrecht. Brussel: E. Story-Scientia.(1988)

Geschiedkundige inleiding tot het recht. Deel II Publiekrecht. Brussel: E. Story-Scientia.

- (1991)

"The Common Law Seen from the Continent" R.C. van Caenegem, Legal History; a European Perspective. London: Hambledon Press.

Cain, M. en K. Kulcsar (1982)

"Thinking Disputes: an Essay on the Origins of the Dispute Industry", Law of Society Review, vol. 16, p. 375-402.

Castells, M. (1996)

The Rise of the Network Society. The Information Age: Economy, Society and Culture, vol. 1. Oxford: Blackwell

C.B.S. (1991)

Rechtshulp in Nederland: rechtsproblemen en rechtshulpverlenende instanties. Recht en statistiek, nr. 10. Voorburg/Heerlen: C.B.S.

van Creveld, M. (1999)

The Rise and Decline of the State. Cambridge: Cambridge University Press.

Dawson, J.P. (1978)

The Oracles of the Law. Westport: Greenwood Press.

Deakin, S. en J. Michie (eds.)(1997)

Contracts, Cooperation and Competition: Studies in Economics, Management and Law. Oxford: Oxford University Press. 
Demuylder, P., G. Franssen, J. van Houtte en F. van Loon (1999)

De gerechtelijke achterstand in België: enkele concrete cijfers. Brussel: Ministerie van Justitic.

Dieckmann, J. (2000)

"Neue gesetzgeberische Wege zur auszergerichtlichen Streitschlichtung" Zeitschrift für Gesetzgebung, Jrg. 15, p. 1-10.

Donner, J.H.P. (1995)

"Hollen of stilstaan. Functie en functioneren van de rechterlijke macht", Justitiële verkenningen, jrg. 21, nr. 2, p. 41-61.

Dohmen, J. (1996)

De vriendenrepubliek. Limburgse kringen. Nijmegen: SUN.

Dore, R. (1992)

"Goodwill and the Spirit of Market Capitalism", Granovetter en Swedberg (eds.) The Sociology of Economic Life, p. 159-180.

Dunworth, T. en J. Rogers (1996)

"Corporations in Court: Big Business Litigation in U.S. Federal Courts, 1971-1991", Law and Social Inquiry, vol. 21, p. 497-592.

Elias, N. (1971)

Wat is sociologie? Utrecht: Het Spectrum.

- (1982)

Het civilisatieproces. Sociogenetische en psychogenetische onderzoekingen. Deel 2. Utrecht: het Spectrum.

Eshuis, R.J.J. (1998)

Een kwestie van tijd. Onderzoek naar de doorlooptijd in handelszaken. Den Haag: WODC.

Felsteiner, W.L.F., R.L. Abel, A. Sarat (1981)

"The Emergence and Transformation of Disputes: Naming, Blaming and Claiming...", Law ơ Society Review, vol. 15, p. 631-654.

Friedman, L.M. en R. Percival (1976)

"A Tale of Two Courts: Litigation in Alameda and San Benito Counties", Law o Society Review, vol. 10, p. 267. 
Galanter, M (1974)

"Why the "Haves" Come Out Ahead: Speculations on the Limits of Legal Change", Law of Society Review, vol. 9, p. 95-160.

- (1981)

"Justice in Many Rooms: Courts, Private Ordering and Indigenous Law" Journal of Legal Pluralism, vol. 19, p. 1-47.

- (1983)

"Reading the Landscape of Disputes: What We Know and Don't Know (and Think We Know) About Our Alledgedly Contentious and Litigious Society", UCLA Law Review, vol. 31, p.4-71.

- (1984)

"Worlds of Deals: Using Negotiation To Teach About Legal Process" Journal of Legal Education, vol. 34, p. 268-276.

- (1986)

"The Day After the Litigation Explosion", Maryland Law Review, vol. 46, p.3-39.

- (1986)

"Adjudication, Litigation, and Related Phenomena", L. Lipson en S. Wheeler (eds.) Law and the Social Sciences. New York: Russell Sage Foundation, p. 151-257.

- (1999)

"Farther Along" Law of Society Review, vol. 33, p.1113-1123

Galanter, M. en J. Rogers (1991)

The Transformation of American Business Disputing: Some Preliminary Observations. Working Paper 10-3, Disputes processing research program. Institute for Legal Studies, University of Wisconsin.

Garland, D. (1990)

Punishment and Modern Society. Oxford: Clarendon Press.

Genn, H. (1999)

Paths to Jusitce: What People Do and Think About Going to Law. Oxford: Hart.

Giddens, A. (1976)

New Rules of Sociological Method. London: Hutchinson.

- (1977)

Studies in Social and Political Theory. London: Hutchinson.

- (1984)

The Constitution of Society. Cambridge: Polity Press.

- (1985) 
The Nation-State and Violence. Cambridge: Polity Press

- (1990)

The Consequences of Modernity. Cambridge: Polity Press

- (1991)

Modernity and Self-Identity. Cambridge: Polity Press.

Granovetter, M. (1985)

"Economic Action and Social Structure: the Problem of Embeddedness", American Journal of Sociology, vol. 91, p. 481-510.

Griffiths, J. (1983)

"The General Theory of Litigation" Zeitschrift fir Rechtssoziologie, Jrg. 2, p. 145-201.

- (1986)

"What Is Legal Pluralism?" Journal of Legal Pluralism, vol. 24, p. 1-50.

- (red.)(1996)

De sociale werking van het recht. Nijmegen: Ars Aequi Libri.

Gijsbers, E.J. en A.G.L. Romme (1996)

"ISO-certificatie als opstap naar TQM? Invoering van kwaliteitsmanagement vanuit een systeemdynamisch gezichtspunt" Management en Onderneming, p. 374-395.

Halay, J.O.(1978)

"The Myth of the Reluctant Litigant", Journal of Japanese Studies, vol. 4, p. 359-390.

$-(1991)$

Authority Without Power: Law and the Japanese Paradox. New York: Oxford University Press.

- (1993)

"A Response to Johnson", Law ơ Society Review, vol. 27, p. 639-645.

Held, D. (1992)

"The Development of the Modern State", S. Hall en B. Gieben (eds.) Formations of Modernity. Cambridge: Polity Press/Open University, p. 72-125. - (1995)

Democracy and the Global Order. From the Modern State to Cosmopolitan Governance. Stanford: Stanford University Press. 
Hobson, J.M. (2000)

The State and International Relations. Cambridge: Cambridge University Press.

Hockema, A. (1985)

"Stromingen in de Nederlandse rechtssociologie van de afgelopen twintig jaar", Recht en kritiek, jrg 11, p. 27-43.

van Houtte, J., V. Thielman en K. De Valck (1996)

De zakenwereld en de juridische dienstverlening. Leuven: Acco.

Huyse,L. (1989)

De kleur van het recht. Leuven: Kritak.

ISK, Instituut voor sociale kommunikatic (1987)

De advocaat en het m.k.b in 1987. Rapport voor de N.O.v.A.

-(1992)

De advokaat en het m.k.b. in 1992. Rapport voor de N.O.v.A.

Ippel, P. (1989)

Reacties op rechtsbescherming in twee dienstverlenende organisaties. Zwolle: Tjeenk Willink.

Jettinghoff, A. (1991)

"Daderprofielen in het privaatrecht", P.J. van Koppen en H.F.M. Crombag (red.) De menselijke factor: psychologie voor juristen. Arnhem: Gouda Quint, p. 55-68.

- (1995)

"The Politics of Procedure", paper published in: Legal culture: encounters and transformations, Annual Meeting of RCSL/ISA, 1-4 August, Tokyo, Japan.

"Voorkomen van wanbetalen: profielen in het privaatrecht", P.J. van Koppen, D.J. Hessing, H.F.M. Crombag (red.) Het hart van de zaak. Arnhem: Gouda Quint, p. 63-78.

- (1997)

"Een geval van zelfregulering: kwaliteitszorg en de verspreiding van het ISO-certificaat" Recht der Werkelijkheid, nr. 2, p. 55-67.

- (2000)

"Total War and Twentieth-Century Legal Change" P.J. van Koppen en N.H.M. Roos (eds.) Rationality, Information and Progress in Law and Psychology. Liber amicorum H.F.M. Crombag. Maastricht: Universitaire Pers Maastricht, p. 281-294. 
Jettinghoff, A. en E. Langerwerf (1982)

"Over rechters en rechtbanken", A.J. Hoekema en J. van Houtte (red.) De rechtssociologische werkkamer: beeld van het rechtssociologisch empirisch onderzoek. Deventer: Van Loghum Slaterus, p.15-40.

Johnson, D.T. (1993)

"Authority Without Power: Haley on Japan's Law and Politics" Law o Society Review, vol. 27, p. 619-638.

Kagan, R.A. (1984)

"The Routinization of Debt Collection: an Essay on Social Change and Conflict in the Courts", Law of Society Review, vol. 18, p. 323-371.

Kawashima, T. (1964)

"Dispute Resolution in Contemporary Japan", A.T von Mehren (ed.) Law in Japan: the Legal Order in a Changing Society. Cambridge: Harvard Universty Press, p. 41-72.

Kenworthy, L., S. Macaulay en J. Rogers (1996)

"'The More Things Change..." Business Litigation and the American Automobile Industry" Law and Social Enquiry, vol. 21, p. 631-678.

Kidder, R.L. (1981)

"The End of the Road? Problems in the Analysis of Disputes", Law of Society Review, vol. 15, p. 717-725.

- (1983)

Connecting Law and Society. An Introduction To Research and Theory. Englewood Cliffs: Prentice Hall.

Klausen, J. (1998)

War and Welfare. Europe and the United States, 1945 to the Present. New York: St. Martin's Press.

Klijn, A. (1991)

Rechtshulp onderzocht en overdacht. Theoretische reflectie en empirisch onderzoek omtrent rechishulp in Nederland 1979-1989. Arnhem: Gouda Quint.

- (1999)

"Over(-)tijdige gerechtelijke afdoening" Rutgers, G.R. en H.E. Bröring (red.) Rechtspraak op tijd. Den Haag: Boom. 
van Koppen, P.J. en M. Malsch (1997)

"De waarde van civiele vonnissen" P.J. van Koppen, D.J. Hessing en H.F.M. Crombag (red.) Het hart van de zaak. Deventer: Gouda Quint, p. 611-621.

Kratchowil, F. (1995)

"Sovereignty as Dominium. Is There a Right of Humanitarian Intervention?" G.M. Lyons \& M. Mastanduno (eds.) Beyond Westphalia? State Sovereignty and International Intervention. Baltimore: John Hopkins University Press, p. $21-42$.

Macaulay, S. (1963)

"Non-Contractual Relations in Business: a Preliminary Study", American Sociological Review, vol. 28, p. 55-67.

- (1977)

"Elegant Models, Empirical Pictures, and the Complexities of Contract" Law ó Society Review, vol. 11, p.507-528.

- (1985)

"An Empirical View of Contract" University of Wisconsin Law Review, p. 465-482.

- (1996)

"Organic Transactions: Contract, Frank Lloyd Wright, and the Johnson building", Wisconsin Law Review, vol. 1, p. 75-121.

Mann, M. (1993)

The Sources of Social Power. Vol. II. The Rise of Classes and Nation-States, 1760-1940. Cambridge: Cambridge University Press.

Merry, S. E. (1990)

Getting Justice and Getting Even. Chicago: University of Chicago Press.

Mitchell, R.H. (1976)

Thought Control in Prewar Japan. Ithaca: Cornell University Press.

Miyazawa, S. (1987)

"Taking Kawashima Seriously: a Review of Japanese Research on Japanese Legal Consciousness and Disputing Behavior" Law \& Society Review, vol. 21, p. 219-241.

Monté verLoren en J.L. Spruit (1982) Hoofdlijnen uit de ontwikkeling der rechterlijke organisatie in de Noordelijke Nederlanden tot de Bataafse omwenteling. Deventer: Kluwer. 
Munger, F. (1993)

"Sociology of Law for a Postliberal Society", Loyola of Los Angeles Law Review, vol. 27, p. 89.

ten Napel, H.M. (1994)

"De veramerikanisering van de Nederlandse rechter" L. de Groot-van Leeuwen e.a. (red.) Het gezag van de rechter. Amsterdam: SISWO.

Nelken, D. (1994)

"Reflexive Criminology?" D, Nelken (ed.) The Futures of Criminology. London: Sage, p. 7-42.

-(1997)

"Puzzling out Legal Culture: a Comment on Blankenburg" D. Nelken (ed.) Comparing Legal Cultures. Aldershot: Dartmouth, p. 69-92.

Nelson, R.L. (1988)

"Ideology, Scholarship, and Sociolegal Change: Lessons from Galanter and the "Litigation Crisis", Law of Society Review, vol. 21, p. 677-694.

Niemeijer, E. (1991)

Geschillen over bouwplannen. Deventer: Kluwer.

Padoa-Schioppa, A. (ed.)(1997)

Legislation and Justice. Oxford: Clarendon Press.

Perrow, C. (1990)

"A Society of Organizations" Theory and Society, vol. 20, p. 725-762.

Peters, A.A.G. (1972)

"Maatschappelijke verandering en rechtsontwikkeling. De veranderende rol van rechter, wet en proces" Recht als instrument van behoud en verandering. Opstellen aangeboden aan J.J.M. van der Ven. Deventer: Kluwer, p. 143-157. - (1982)

"Eurocentrism in Law" Nuffic Bulletin, vol. 26, p. 91-107.

- (1993)

Recht en samenleving in Japan. Arnhem: Gouda Quint.

Pieterman, R. (1990)

De plaats van de rechter in Nederland 1813-1920. Arnhem: Gouda Quint. - (1993)

"Rechtssociologie tussen sociologie en rechtswetenschap; John Griffiths en de 
theorie van de empirische rechtssociologie" Recht der Werkelijkheid. Nr. 1, p. 5-24.

- (1998)

Dubbelzinnig recht. Rechtssociologische inzichten in het omgaan met conflicten in de moderne samenleving. Rotterdam: Donner Boeken.

Poggi, G. (1991)

The State, its Nature, Development and Prospects. Cambridge: Polity Press.

Porter, B.D. (1994)

War and the Rise of the State. The Military Foundations of Modern Politics. New York: The Free Press.

Post, G. (1963)

"Law and Politics in the Middle Ages: the Medieval State as a Work of Art", K. Fischer Drew en F.S. Lear (eds.) Perspectives in Medieval History. Chicago.

Pottschmidt, R. en U. Rohr (1990)

Privatrecht für den Kaufman. München: Vahlen.

Powell, W.W. (1990)

"Neither Market nor Hierarchy: Network Forms of Organization" B.M. Staw en L.L. Cummings (eds.) Research in Organizational Behavior, vol. 12, London: JAI, p. 295-336.

Projectgroep 2000 (2001)

Justitie in beweging. Brussel: Koning Boudewijnstichting.

Ramseyer, M. (1989)

"The Rational Litigant: Settlement Amounts and Verdict Rates in Japan" Journal of Legal Studies, vol. 18, p. 263-290.

Riezebos, R. en E. Waarts (1994)

Power Play. Groningen: Wolter-Noordhoff.

Rokumoto, K. (1995)

"Cultural Factors in Comparative Socio-legal Analysis", paper published in Legal Culture: Encounters and Transformations, annual meeting of RCSL/ISA, 1-4 August, Tokyo, Japan. 
Rosenberg, M. (1981)

"Civil Justice Research and Civil Justice Reform:, Law \& Society Review, vol. 15, p. 473.

Schellevis, J., A. Veraart, E. Verweij en O. Vries (1995)

De Nederlandse bouw internationaal vergeleken. Amsterdam: Economisch Instituut voor de Bouwnijverheid

Schuyt, C.J.M. (1981)

Recht en samenleving. Assen: Van Gorcum.

Schuyt, C.J.M. en A. Jettinghoff (1981)

"Recht" L. Rademaker (red.) Sociale kaart van Nederland. Deel 4, Kerninformatic. Utrecht: Het Spectrum, p. 237-269.

Schuyt, K., Groenendijk, K. en B. Sloot (1976)

De weg naar het recht. Deventer: Kluwer.

Schwartz, R.D. (1954)

"Social Factors in the Development of Legal Control: a Case Study of Two Israeli Settlements" Yale Law Journal, vol. 63, p. 471-491.

Snel, E. (1996)

"Voorbij 'engineering' en 'enlightenment'" Beleid en Maatschappij, vol. 23, p.109-120.

Spruyt, H. (1994)

The Sovereign State and Its Competitors. An Analysis of Systems Change. Princeton: Princeton University Press.

Starreveld, D. en J.P. Thomassen (1999)

"Klachtenmanagement: een stap-voor-stap benadering" Kwaliteit in bedrijf, september, p. 6-10.

Stinchcombe, A.L. (1989)

"Contracts as Hierarchical Documents", A.L. Stinchcombe en C.A. Heiner (eds.) Organization Theory and Project Management:Administering Uncertainty in Norwegian Offshore Oil. Oslo: Norwegian University Press, p. 121-171.

Strayer, J.R. en D.C. Munro (1959)

The Middle Ages. 395-1500. New York: Appleton. 
Stuurman, S. (1993)

"Duizend jaar staatsvorming in Europa" Amsterdams Sociologisch Tijdschrift, jrg. 20, p. 74-94.

Swedberg, R. (1994)

"Markets as Social Structures", N.J. Smelser en R. Swedberg (eds.) The Handbook of Economic Sociology. Princeton: Princeton University Press, p. 255-282. - (2000)

Entrepreneurship, the Social Science View. Oxford: Oxford University Press.

Swedberg, R. en M. Granovetter (1992)

"Introduction" Granovetter, M. en R. Stuedberg (eds.) The Sociology of Economic Life. Boulder: Westview Press, p. 1-26.

Tamanaha, B. (1995)

"The Lessons of Law-and-Development Studies", The American Journal of International Law, vol. 89, p. 470-486.

Tanase, T. (1990)

"The Management of Disputes: Automobile Accident Compensation in Japan”, Law \& Society Review, vol. 24, p. 651-692.

Tate, C.N. (1992)

"Courts and Crisis Regimes: a Theory Sketch with Asian Case Studies" Political Research Quarterly, vol. 46, p. 311-338.

Tate, C.N. en T. Vallinder (1999)

The Global Expansion of Judicial Power. New York: New York University Press.

Tilly, C. (1985)

"War Making and State Making as Organized Crime", P.B. Evans, D. Rueschemeyer, T. Skocpol (eds.) Bringing the State Back In. Cambridge: Cambridge University Press.

- (1990)

Coercion, Capital, and European States, A.D. 990-1990. Oxford: Blackwell.

Tilly, C. en W.P. Blockmans (eds.)(1994)

Cities and the Rise of States in Europe. A.D. 1000-1800. Boulder: Westview Press 
Timmerman, L. (1999)

"Kroniek van het vennootschapsrecht", Nederlands Juristenblad, jig. 74, p. 1495-1501.

Trubek. D.M. (1981)

"Studying Courts in Context", Law \& Society Review, vol 15, p. 485-501. $-(1988)$

"The Handmaiden's Revenge: on Reading and Using the Newer Sociology of Civil Procedure" Law and Contemporary Problems, vol 51, p. 111. -(1990)

"Back To the Future: the Short, Happy Life of the Law and Society Movement" Florida State University Law Review, vol. 18, p. 1-55.

van der Veen, A., en O. Dicke (1990)

Fusies in de advocatuur. Rapport voor de N.O.v.A. Amsterdam: Inter/view.

van der Veen, R. (1990)

De sociale grenzen van beleid. Een onderzoek naar de uitvoering en effecten van het stelsel van sociale zekerheid. Leiden: Stenfert Kroese.

- (2000)

"De verzorgingsstaat in de laatmoderniteit" Beleid en Maatschappij, jrg. 27, p. 63-77.

Verhey, N. (1997)

"Rechtsbescherming in Nederland. Teveel van het goede?"Justitiële Verkenningen, jig. 23, p. 13-26.

Verkruisen, W.G. (1993)

Dissatisfied Patients: their Experiences, Interpretations and Actions. Diss., Groningen.

Verwoerd, J.R.A.(1988)

Beroep op de rechter als laatste remedie. Arnhem: Gouda Quint.

Volkmann, J.-C. (1997)

Bien connaitre les généalogies des rois de France. Paris: Gisserot.

Wettmann, R. en K. Jungjohann (1989)

Inanspruchnahme anwaltlicher Leistungen. Zugangsschwellen, Beratungsbedarf und Anuvaltsimage. Köln: Bundesanzeiger. 
Werkgroep Effecten Rechtspraak (1998)

Rechtspraak en rechtshandhaving: maatschappelijke effecten van verbetering. Den Haag: Ministerie van Justitie.

Wilterdink, N. en B. Van Heerikhuizen (red.) (1999)

Samenlevingen. Een verkenning van het terrein van de sociologie. Groningen: Wolters Noordhoff.

van Wolferen (1989)

Japan. De ontzichtbare drijfveren van een wereldmacht. Amsterdam: Muntinga/Balans.

Zwetsloot, G. en P. Sprengers (1992)

Op zoek naar synergie: het combineren van Arbo-, milieu-en kwalteitszorg door koploperbedrijven. 's Gravenhage: Vuga.

\section{Zijderveld, A.C. (1991)}

Staccato cultuur, flexibele maatschappij en verzorgende staat. Utrecht: Lemma. 



\section{CURRICULUM VITAE}

Alex Jettinghoff is op 8 februari 1947 geboren te Rotterdam. In 1965 behaalde hij zijn Gymnasiumdiploma aan het Libanon Lyceum te Rotterdam. Datzelfde jaar begon zijn rechtenstudie aan de Nederlandse Economische Hogeschool te Rotterdam die in 1971 werd afgerond. Van 1971 tot 1975 was hij medewerker aan de Erasmus Universiteit te Rotterdam, en deed onderzoek naar de praktijk rond de betalingsbevelprocedure en de ontwikkeling van de output van de rechterlijke macht. In 1975 trad hij in dienst van de Katholieke Universiteit Nijmegen in verband met onderzoek naar het functioneren van de Raden van Beroep. Tevens verrichtte hij onderzoek naar de kwantitatieve ontwikkeling van juridische beroepen in Nederland. Na vanaf 1981 hoofdzakelijk het huisvaderschap te hebben beoefend, werd hij in 1983 universitair docent bij de vakgroep Metajuridica van de Faculteit der Rechtsgeleerdheid van de Rijksuniversiteit Limburg. De tijd die voor onderzoek beschikbaar was heeft hij vooral besteed aan de in het 'woord vooraf omschreven interessegebieden. 
HET KOMT ZELDEN VOOR

Beheersing van klachren en geschillen in relaties tussen bedrifiven

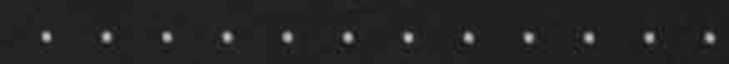

ISBN 9080587923 